\title{
Visible Light-Mediated Direct C-H Aroylation and Alkylation of Heteroarenes
}

Rui Chang, ${ }^{\S}$ Jie Fang, ${ }^{\S}$ Jian-Qiang Chen, Dan Liu, Guo-Qiang Xu and Peng-Fei $\mathrm{Xu}^{*}$

State Key Laboratory of Applied Organic Chemistry, College of Chemistry and Chemical Engineering, Lanzhou University, Lanzhou 730000, P. R. China. Corresponding author: xupf@lzu.edu.cn 


\section{Contents}

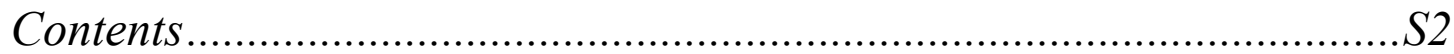

1. Reaction Optimization .........................................................S3

1.1 Optimization Table of Minisci Aroylation..................................................S3

1.2 Optimization Table of Minisci Alkylation ...................................................S3

2. Mechanism Studies .................................................................S6

2.1 Radical Trapping Experiments..............................................................................S6

2.2 Fluorescence Quenching Experiments.........................................................S6

2.3 Cyclic Voltammetry Experiments ...........................................................11

2.4 Determination of Quantum Yield.....................................................................S13

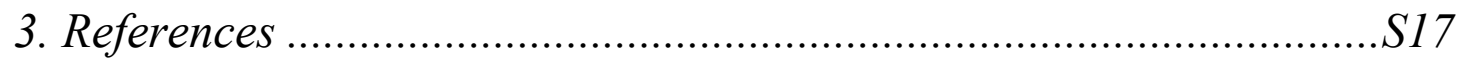

4. NMR Spectra of Compounds ....................................................S18 


\section{Reaction Optimization}

\subsection{Optimization Table of Minisci Aroylation}

Table S1. Optimization of reaction conditions ${ }^{a}$.

\begin{tabular}{|c|c|c|c|c|c|c|}
\hline entry & catalyst & solvent & $1 \mathbf{a}: 2 \mathbf{a}$ & additive & time(h) & yield $(\%)^{b}$ \\
\hline 1 & $\mathrm{Ru}(\text { bpy })_{3} \mathrm{Cl}_{2}$ & $\mathrm{CH}_{3} \mathrm{CN}$ & $1: 2$ & - & 48 & NR \\
\hline 2 & $\operatorname{Ir}(\mathrm{ppy})_{2}(\mathrm{dtbbpy}) \mathrm{PF}_{6}$ & $\mathrm{CH}_{3} \mathrm{CN}$ & $1: 2$ & - & 48 & NR \\
\hline 3 & Eosin $Y$ & $\mathrm{CH}_{3} \mathrm{CN}$ & $1: 2$ & - & 48 & NR \\
\hline 4 & Rose Bengal & $\mathrm{CH}_{3} \mathrm{CN}$ & $1: 2$ & - & 48 & NR \\
\hline 5 & $f a c-\operatorname{Ir}(\mathrm{ppy})_{3}$ & $\mathrm{CH}_{3} \mathrm{CN}$ & $1: 2$ & - & 48 & 32 \\
\hline 6 & $f a c-\operatorname{Ir}(\mathrm{ppy})_{3}$ & $\mathrm{CH}_{3} \mathrm{CN}$ & $1: 2$ & TFA & 48 & 20 \\
\hline 7 & $f a c-\operatorname{Ir}(\mathrm{ppy})_{3}$ & $\mathrm{CH}_{3} \mathrm{CN}$ & $1: 2$ & $\mathrm{TsOH}$ & 48 & 11 \\
\hline 8 & $f a c-\operatorname{Ir}(\mathrm{ppy})_{3}$ & $\mathrm{CH}_{3} \mathrm{CN}$ & $1: 2$ & $\mathrm{~K}_{2} \mathrm{CO}_{3}$ & 48 & 21 \\
\hline 9 & $f a c-\operatorname{Ir}(\mathrm{ppy})_{3}$ & $\mathrm{CH}_{3} \mathrm{CN}$ & $1: 2$ & $\mathrm{~K}_{2} \mathrm{HPO}_{4}$ & 48 & 15 \\
\hline 10 & $f a c-\operatorname{Ir}(\mathrm{ppy})_{3}$ & $\mathrm{CH}_{3} \mathrm{CN}$ & $1: 2$ & $\mathrm{CsCO}_{3}$ & 48 & 10 \\
\hline 11 & $f a c-\operatorname{Ir}(\mathrm{ppy})_{3}$ & $\mathrm{CH}_{3} \mathrm{CN}$ & $1: 2$ & - & 72 & 35 \\
\hline 12 & $f a c-\operatorname{Ir}(\mathrm{ppy})_{3}$ & $\mathrm{CH}_{3} \mathrm{CN}$ & $1: 6$ & - & 72 & 74 \\
\hline 13 & $f a c-\operatorname{Ir}(\mathbf{p p y})_{3}$ & $\mathrm{CH}_{3} \mathrm{CN}$ & $1: 10$ & - & 72 & 88 \\
\hline 14 & $f a c-\operatorname{Ir}(\mathrm{ppy})_{3}$ & acetone & $1: 10$ & - & 72 & 77 \\
\hline 15 & $f a c-\operatorname{Ir}(\mathrm{ppy})_{3}$ & DMF & $1: 10$ & - & 72 & 47 \\
\hline 16 & $f a c-\operatorname{Ir}(\mathrm{ppy})_{3}$ & DCM & $1: 10$ & - & 72 & 45 \\
\hline 17 & $f a c-\operatorname{Ir}(\mathrm{ppy})_{3}$ & THF & $1: 10$ & - & 72 & NR \\
\hline 18 & $f a c-\operatorname{Ir}(\mathrm{ppy})_{3}$ & toluene & $1: 10$ & - & 72 & NR \\
\hline $19^{c}$ & $f a c-\operatorname{Ir}(\mathrm{ppy})_{3}$ & $\mathrm{CH}_{3} \mathrm{CN}$ & $1: 10$ & - & 72 & 24 \\
\hline 20 & none & $\mathrm{CH}_{3} \mathrm{CN}$ & $1: 10$ & - & 72 & NR \\
\hline $21^{d}$ & $f a c-\operatorname{Ir}(\mathrm{ppy})_{3}$ & $\mathrm{CH}_{3} \mathrm{CN}$ & $1: 10$ & - & 72 & NR \\
\hline
\end{tabular}

${ }^{a}$ Unless otherwise noted, reaction conditions are as follows: substrate 1a $(0.2 \mathrm{mmol}), \mathbf{2 a}(2-10$ equiv.), photocatalyst $(0.004 \mathrm{mmol})$, additive $(0.2 \mathrm{mmol})$, solvent (anhydrous, $2 \mathrm{~mL}), 25 \mathrm{~W}$ blue LED strip, room temperature, under $\mathrm{N}_{2}$ atmosphere. ${ }^{b}$ Isolated yield. ${ }^{c} f a c-\operatorname{Ir}(\mathrm{ppy})_{3}(0.002 \mathrm{mmol}) .{ }^{d}$ In the absence of light source.

\subsection{Optimization Table of Minisci Alkylation}

Table S2. Optimization of oxidants ${ }^{a}$.

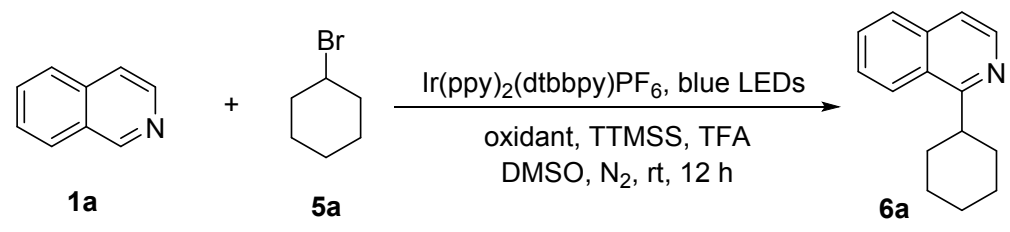




\begin{tabular}{ccc}
\hline entry & oxidant & yield $(\mathbf{\%})^{\boldsymbol{b}}$ \\
\hline 1 & $\mathrm{DTBP}$ & 17 \\
2 & $\mathrm{BPO}$ & 32 \\
3 & $N$-ethoxypyridinium hexafluorophosphate & 36 \\
4 & $\left(\mathrm{NH}_{4}\right)_{2} \mathrm{~S}_{2} \mathrm{O}_{8}$ & 38 \\
5 & $\mathrm{Na}_{2} \mathrm{~S}_{2} \mathrm{O}_{8}$ & 45 \\
6 & $\mathrm{TBHP}($ in water $)$ & 56 \\
7 & $\mathrm{TBHP}($ in decane $)$ & 60 \\
8 & $\mathrm{TBPB}$ & 63 \\
$\mathbf{9}$ & $\mathbf{K}_{\mathbf{2}} \mathbf{S}_{\mathbf{2}} \mathbf{O}_{\mathbf{8}}$ & $\mathbf{6 5}$ \\
\hline
\end{tabular}

${ }^{a}$ Reaction conditions: 1a $(0.2 \mathrm{mmol}), \mathbf{5 a}(0.4 \mathrm{mmol}), \operatorname{Ir}(\mathrm{ppy})_{2}\left(\mathrm{dtbbpy} \mathrm{PF}_{6}(0.002 \mathrm{mmol}), \mathrm{TFA}(0.3 \mathrm{mmol})\right.$, oxidant $(0.4 \mathrm{mmol})$, TTMSS $(0.3 \mathrm{mmol})$, DMSO (anhydrous, $1.5 \mathrm{~mL})$ and $25 \mathrm{~W}$ blue LED strip under $\mathrm{N}_{2}$ atmosphere at room temperature for $12 \mathrm{~h} .{ }^{b}$ Isolated yield.

Table S3. Optimization of photocatalysts ${ }^{a}$.

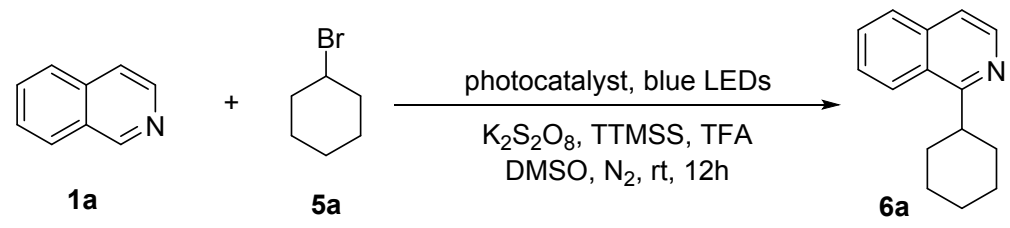

\begin{tabular}{|c|c|c|}
\hline entry & photocatalyst & yield $(\%)^{b}$ \\
\hline 1 & $\operatorname{Ir}(\text { ppy })_{2}(\mathrm{dtbbpy}) \mathrm{PF}_{6}$ & 65 \\
\hline 2 & $f a c-\operatorname{Ir}(\mathrm{ppy})_{3}$ & 61 \\
\hline 3 & $\operatorname{Ir}\left[\mathrm{dF}\left(\mathrm{CF}_{3}\right) \mathrm{ppy}_{2}(\mathrm{dtbbpy}) \mathrm{PF}_{6}\right.$ & 69 \\
\hline 4 & Eosin $\mathrm{Y}$ & 52 \\
\hline 5 & Acr-Mes & 35 \\
\hline 6 & Rose Bengal & 30 \\
\hline 7 & $\mathrm{Ru}(\text { bpy })_{3} \mathrm{Cl}_{2} \cdot 6 \mathrm{H}_{2} \mathrm{O}$ & 51 \\
\hline 8 & $\mathrm{Ru}(\mathrm{bpy})_{3}\left(\mathrm{PF}_{6}\right)_{2}$ & 56 \\
\hline
\end{tabular}

${ }^{a}$ Reaction conditions: 1a $(0.2 \mathrm{mmol}), \mathbf{5 a}(0.4 \mathrm{mmol})$, photocatalyst $(0.002 \mathrm{mmol}), \mathrm{TFA}(0.3 \mathrm{mmol}), \mathrm{K}_{2} \mathrm{~S}_{2} \mathrm{O}_{8}$ (0.4 mmol), TTMSS (0.3 mmol), DMSO (anhydrous, $1.5 \mathrm{~mL}$ ) and $25 \mathrm{~W}$ blue LED strip under $\mathrm{N}_{2}$ atmosphere at room temperature for $12 \mathrm{~h} .{ }^{b}$ Isolated yield.

Table S4. Optimization of solvents ${ }^{a}$.

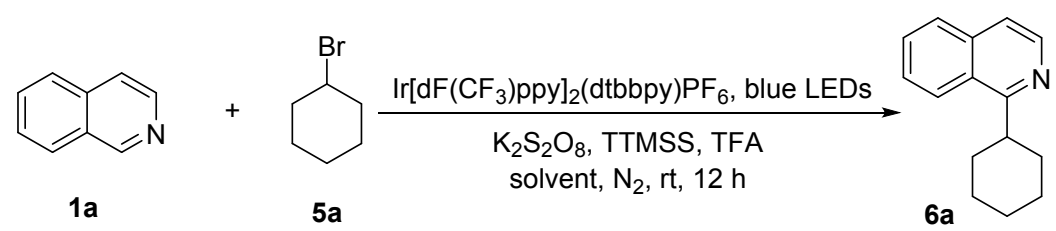




\begin{tabular}{ccc}
\hline 1 & $\mathrm{MeCN}$ & trace \\
2 & $\mathrm{MeCN} / \mathrm{H}_{2} \mathrm{O}=1: 1$ & trace \\
3 & acetone & 55 \\
4 & chlorobenzene & trace \\
5 & DCE & trace \\
6 & DMF & 46 \\
7 & DMA & 51 \\
$\mathbf{8}$ & DMSO & $\mathbf{6 9}$ \\
\hline
\end{tabular}

${ }^{a}$ Reaction conditions: 1a $(0.2 \mathrm{mmol}), \mathbf{5 a}(0.4 \mathrm{mmol}), \operatorname{Ir}\left[\mathrm{dF}\left(\mathrm{CF}_{3}\right) \text { ppy }\right]_{2}(\mathrm{dtbbpy}) \mathrm{PF}_{6}(0.002 \mathrm{mmol}), \mathrm{TFA}(0.3$ $\mathrm{mmol}), \mathrm{K}_{2} \mathrm{~S}_{2} \mathrm{O}_{8}(0.4 \mathrm{mmol})$, TTMSS $(0.3 \mathrm{mmol})$, solvent (anhydrous, $1.5 \mathrm{~mL}$ ) and $25 \mathrm{~W}$ blue LED strip under $\mathrm{N}_{2}$ atmosphere at room temperature for $12 \mathrm{~h} .{ }^{b}$ Isolated yield.

Table S5. Further optimization and control experiments ${ }^{a}$.

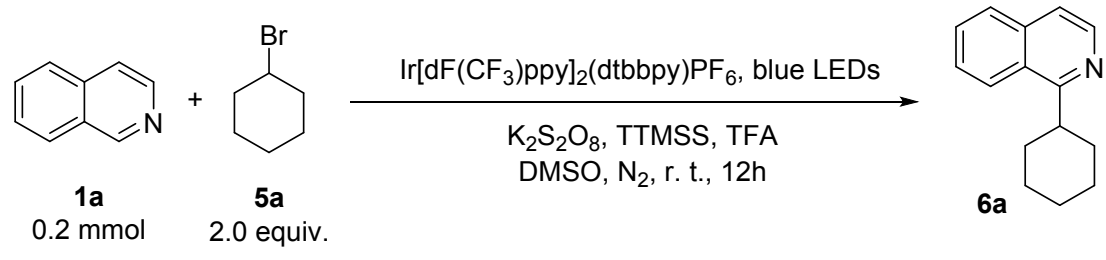

\begin{tabular}{cccccccc}
\hline entry & $\begin{array}{c}\text { photocat. } \\
\text { (mmol) }\end{array}$ & $\begin{array}{c}\text { light } \\
\text { on/off }\end{array}$ & $\begin{array}{c}\mathbf{K}_{2} \mathbf{S}_{\mathbf{2}} \mathbf{O}_{\mathbf{8}} \\
\text { (equiv.) }\end{array}$ & $\begin{array}{c}\text { TTMSS } \\
\text { (equiv.) }\end{array}$ & $\begin{array}{c}\text { TFA } \\
\text { (equiv.) }\end{array}$ & $\begin{array}{c}\text { DMSO } \\
\text { (mL) }\end{array}$ & yield (\%) $^{\boldsymbol{b}}$ \\
\hline 1 & 0.002 & on & 2.0 & 1.5 & 1.5 & 1.5 & 69 \\
2 & 0.002 & on & 2.0 & 2.0 & 1.5 & 1.5 & 78 \\
3 & 0.002 & on & 2.0 & 2.0 & 2.0 & 1.5 & 83 \\
$\mathbf{4}$ & $\mathbf{0 . 0 0 2}$ & on & $\mathbf{2 . 0}$ & $\mathbf{2 . 0}$ & $\mathbf{2 . 0}$ & $\mathbf{1 . 0}$ & $\mathbf{9 0}$ \\
5 & 0 & on & 2.0 & 2.0 & 2.0 & 1.0 & 35 \\
6 & 0 & off & 2.0 & 2.0 & 2.0 & 1.0 & 24 \\
7 & 0.002 & on & 0 & 2.0 & 2.0 & 1.0 & 0 \\
$\mathbf{8}$ & 0.002 & on & 2.0 & 0 & 2.0 & 1.0 & 0 \\
\hline
\end{tabular}

${ }^{a}$ Reaction conditions: 1a $(0.2 \mathrm{mmol}), \mathbf{5 a}(0.4 \mathrm{mmol}), \operatorname{Ir}\left[\mathrm{dF}\left(\mathrm{CF}_{3}\right) \mathrm{ppy}\right]_{2}(\mathrm{dtbbpy}) \mathrm{PF}_{6}(0.002 \mathrm{mmol}), \mathrm{TFA}(0.3$ -0.4 mmol), $\mathrm{K}_{2} \mathrm{~S}_{2} \mathrm{O}_{8}(0.4 \mathrm{mmol})$, TTMSS (0.3-0.4 mmol), solvent (anhydrous, 1.0-1.5 mL) and $25 \mathrm{~W}$ blue LED strip under $\mathrm{N}_{2}$ atmosphere at room temperature for $12 \mathrm{~h} .{ }^{b}$ Isolated yield. 


\section{Mechanism Studies}

\subsection{Radical Trapping Experiments}
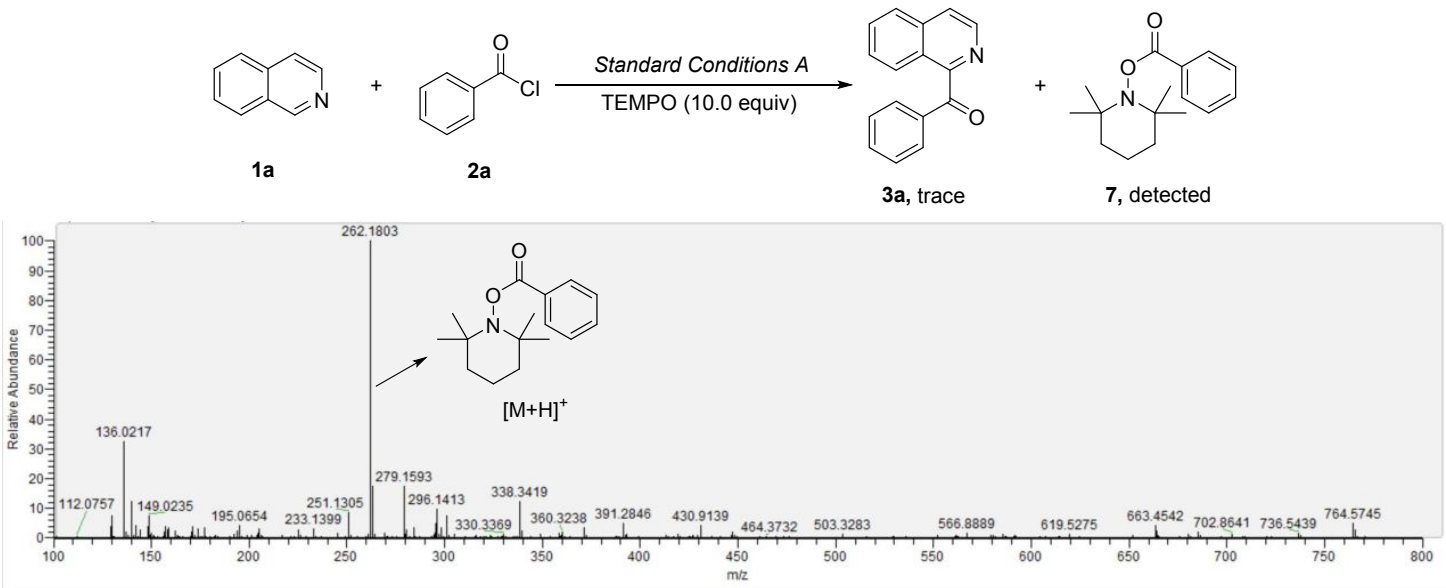

Figure S1. Isoquinoline 1a and benzoyl chloride 2a under standard conditions with TEMPO (10.0 equiv.)
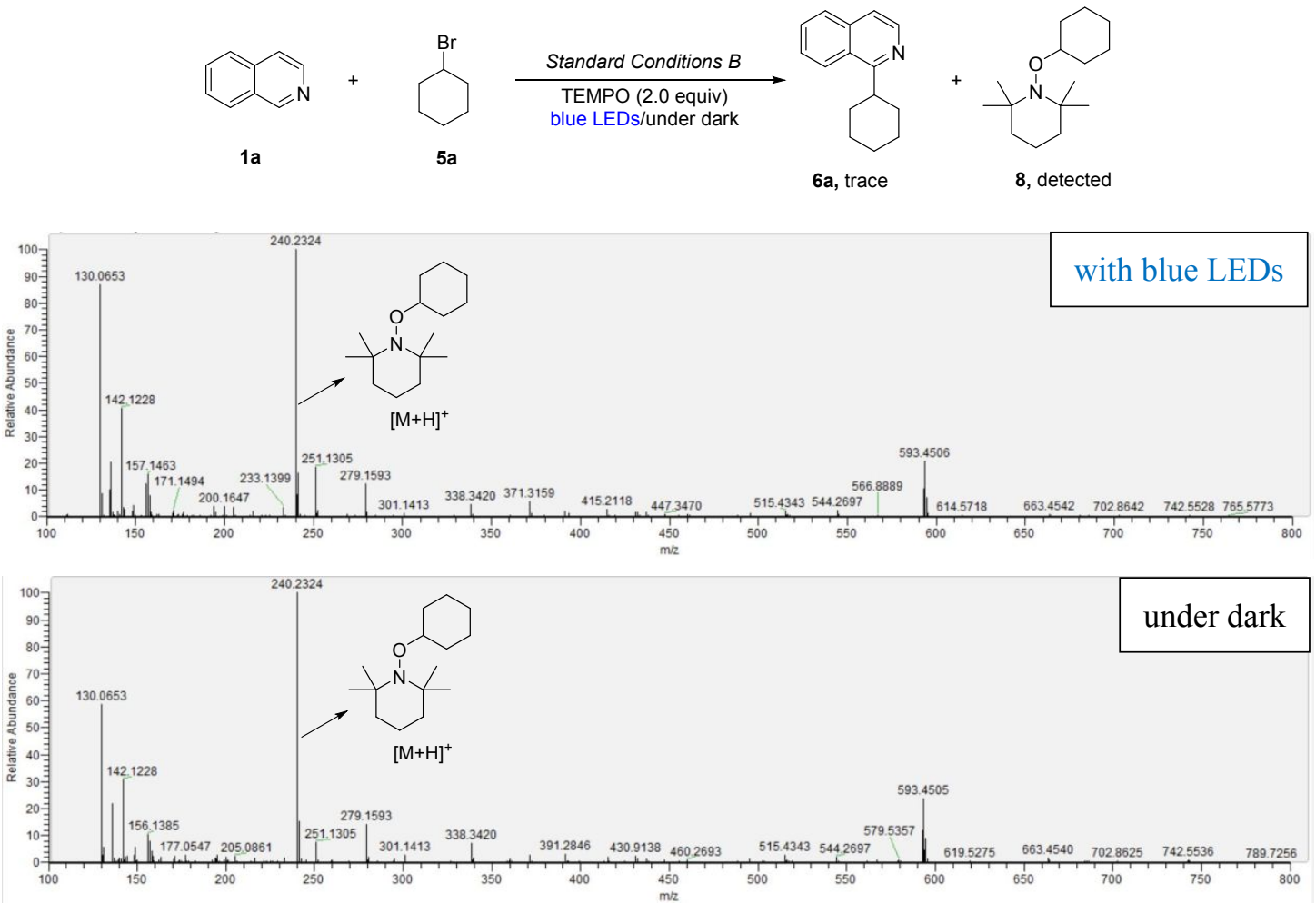

Figure S2. Isoquinoline 1a and bromocyclohexane 5a under standard conditions with TEMPO (2.0 equiv.)

\subsection{Fluorescence Quenching Experiments}




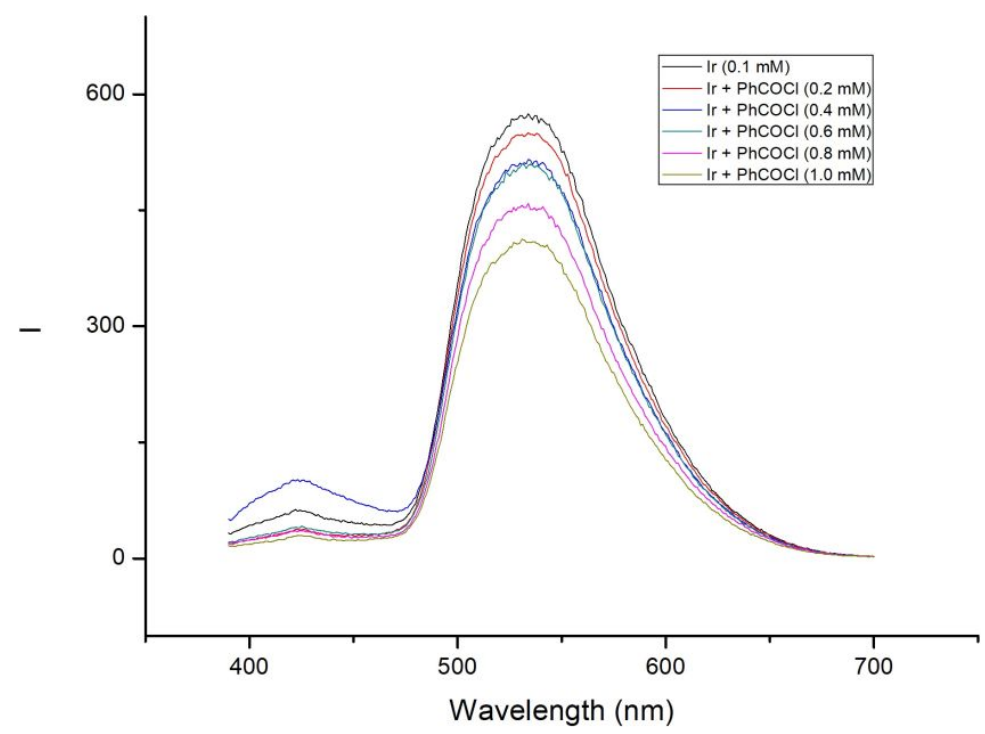

Figure S3. Fluorescence quenching curve with $\operatorname{Ir}(\mathrm{ppy})_{3}$ and benzoyl chloride

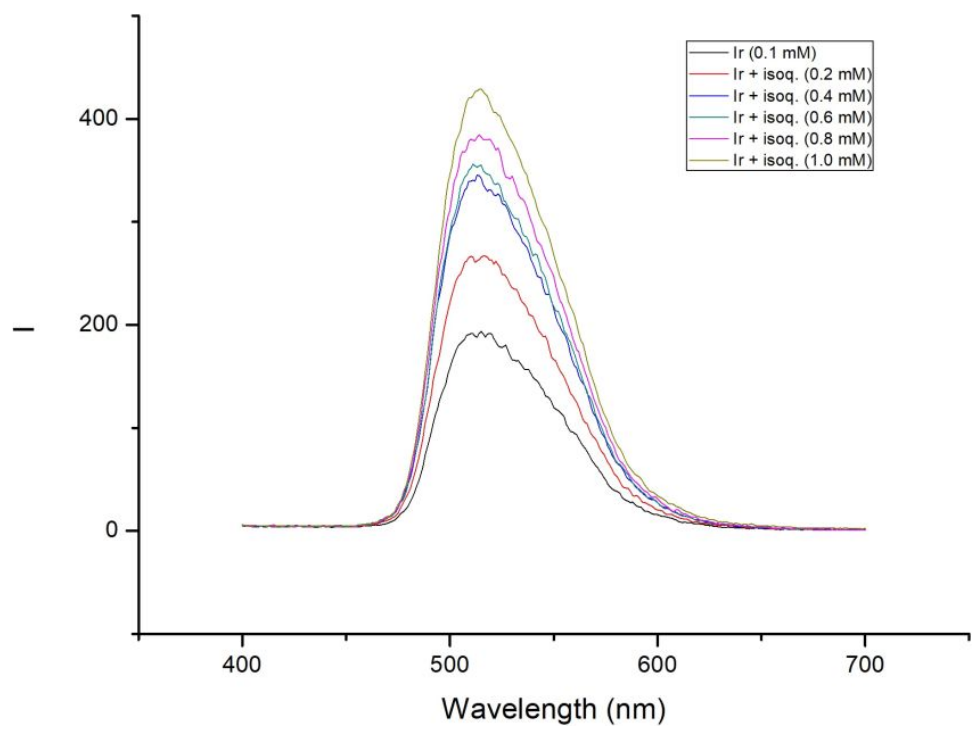

Figure S4. Fluorescence quenching curve with $\operatorname{Ir}(\mathrm{ppy})_{3}$ and isoquinoline 


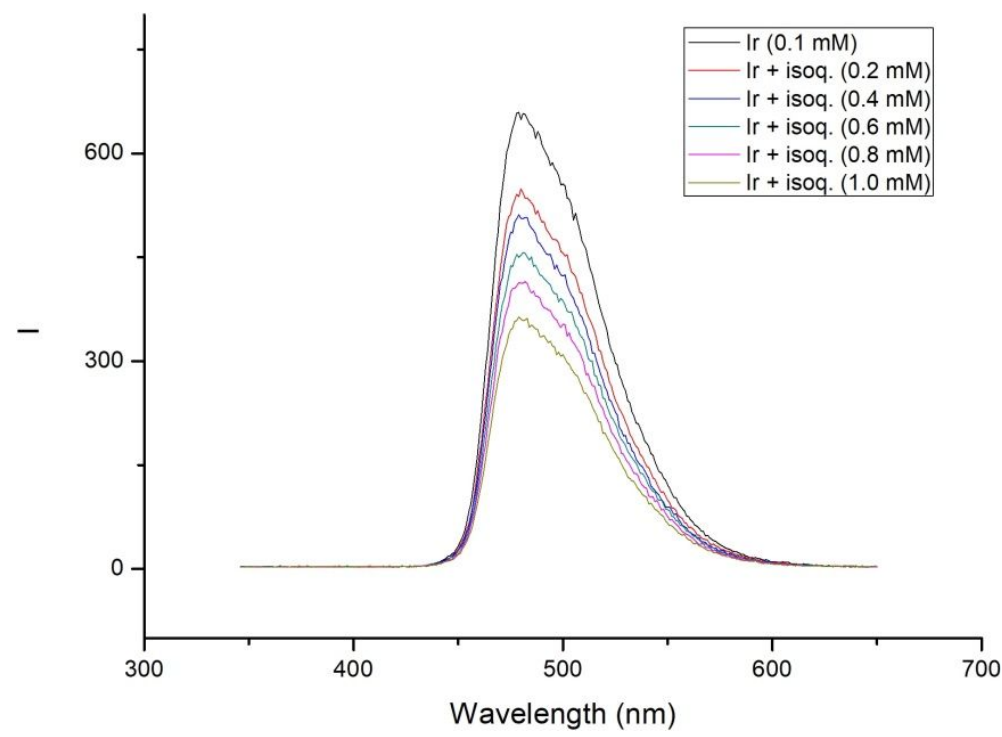

Figure S5. Fluorescence quenching curve with $\left.\operatorname{Ir}\left[\mathrm{dF}_{(\mathrm{CF}}\right) \mathrm{ppy}\right]_{2}(\mathrm{dtbbpy}) \mathrm{PF}_{6}$ and Isoquinoline

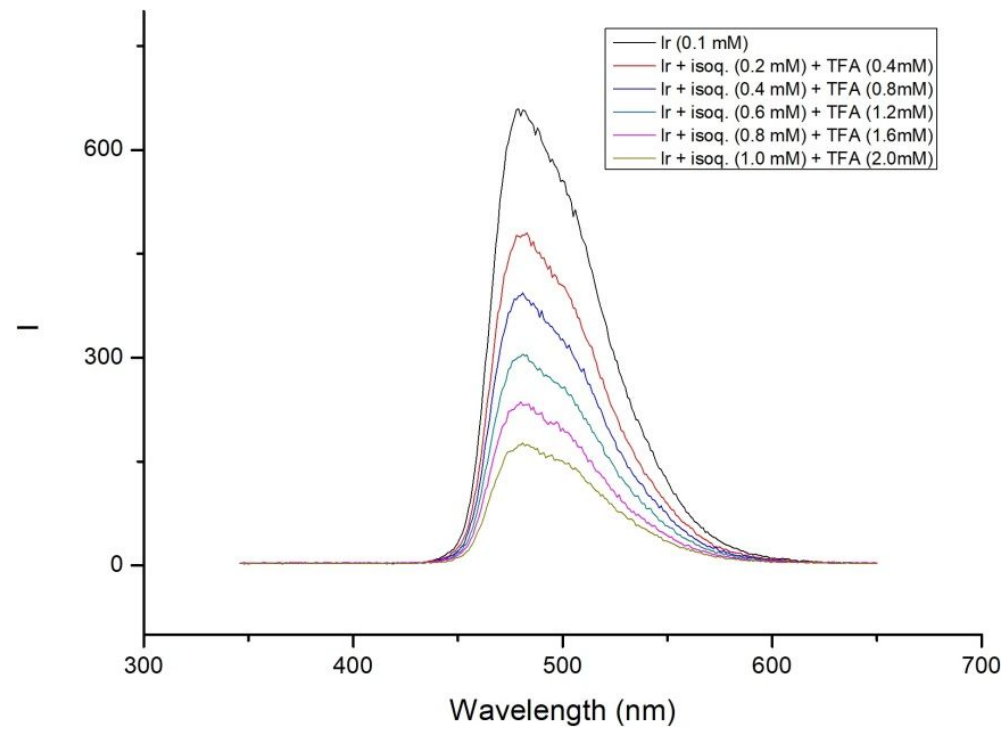

Figure S6. Fluorescence quenching curve with $\operatorname{Ir}\left[\mathrm{dF}\left(\mathrm{CF}_{3}\right) \mathrm{ppy}\right]_{2}(\mathrm{dtbbpy}) \mathrm{PF}_{6}$ and isoquinoline + TFA 


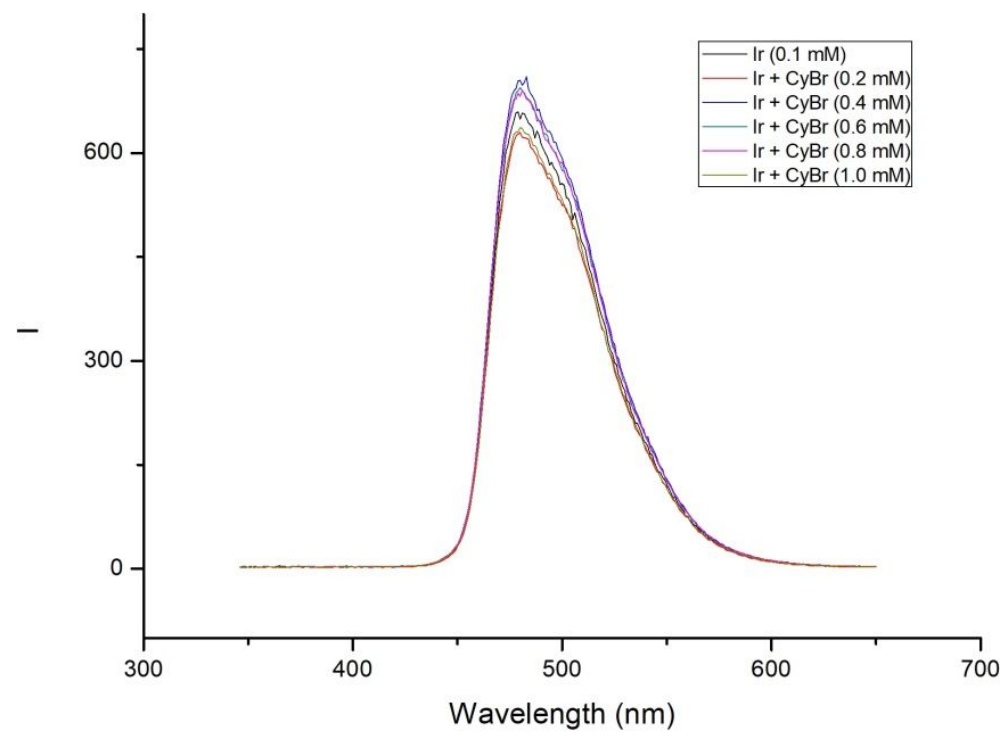

Figure S7. Fluorescence quenching curve with $\operatorname{Ir}\left[\mathrm{dF}\left(\mathrm{CF}_{3}\right) \mathrm{ppy}\right]_{2}(\mathrm{dtbbpy}) \mathrm{PF}_{6}$ and bromocyclohexane

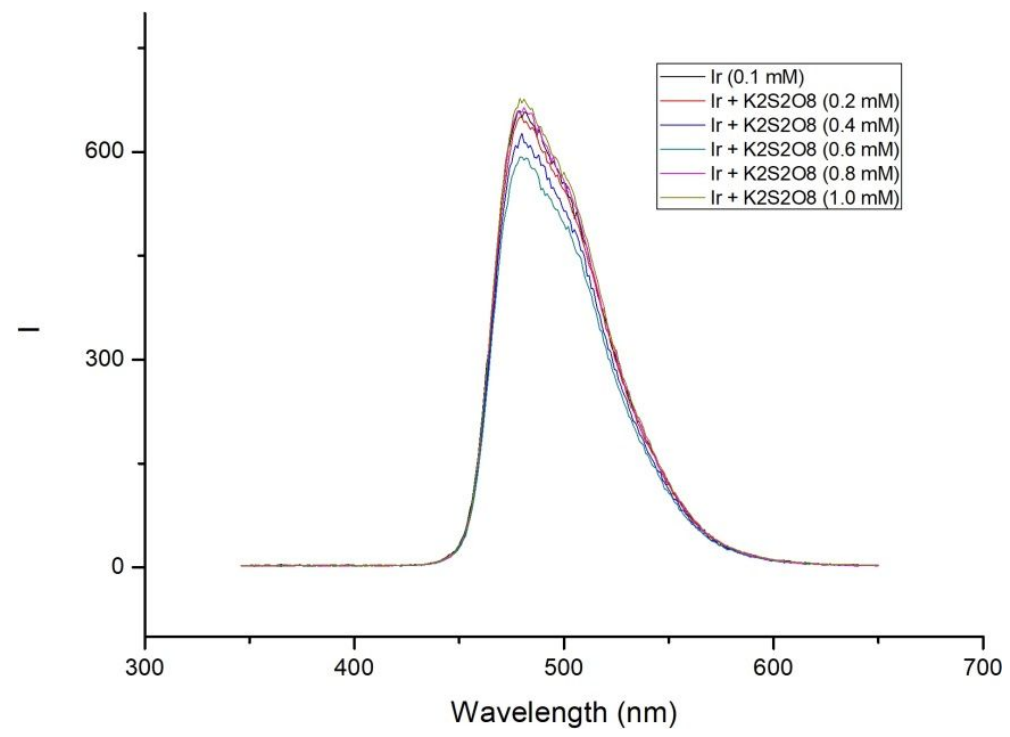

Figure S8. Fluorescence quenching curve with $\operatorname{Ir}\left[\mathrm{dF}\left(\mathrm{CF}_{3}\right) \text { ppy }\right]_{2}(\mathrm{dtbbpy}) \mathrm{PF}_{6}$ and $\mathrm{K}_{2} \mathrm{~S}_{2} \mathrm{O}_{8}$ 


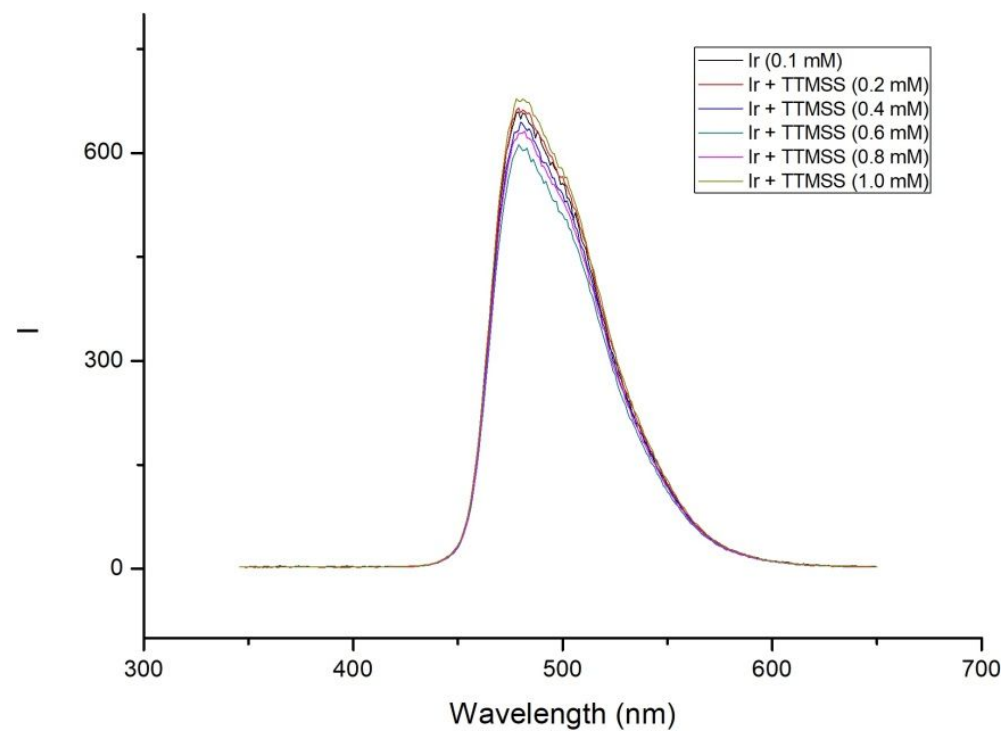

Figure S9. Fluorescence quenching curve with $\left.\operatorname{Ir}\left[\mathrm{dF}_{(\mathrm{CF}}\right) \mathrm{ppy}\right]_{2}(\mathrm{dtbbpy}) \mathrm{PF}_{6}$ and

TTMSS

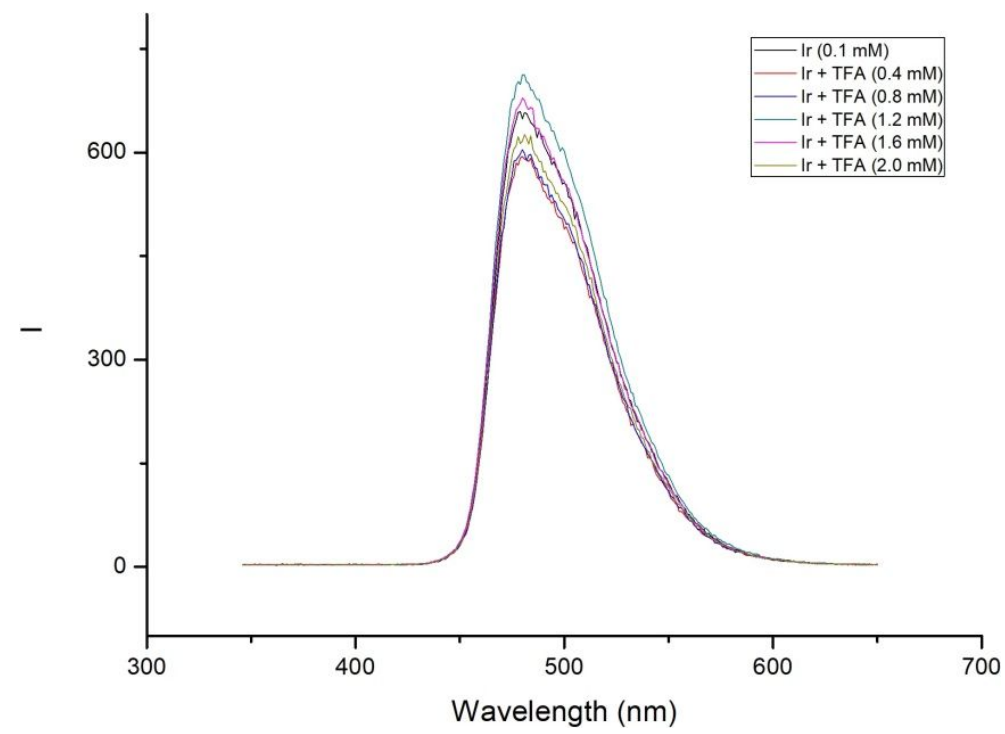

Figure S10. Fluorescence quenching curve with $\operatorname{Ir}\left[\mathrm{dF}\left(\mathrm{CF}_{3}\right) \mathrm{ppy}\right]_{2}(\mathrm{dtbbpy}) \mathrm{PF}_{6}$ and TFA 


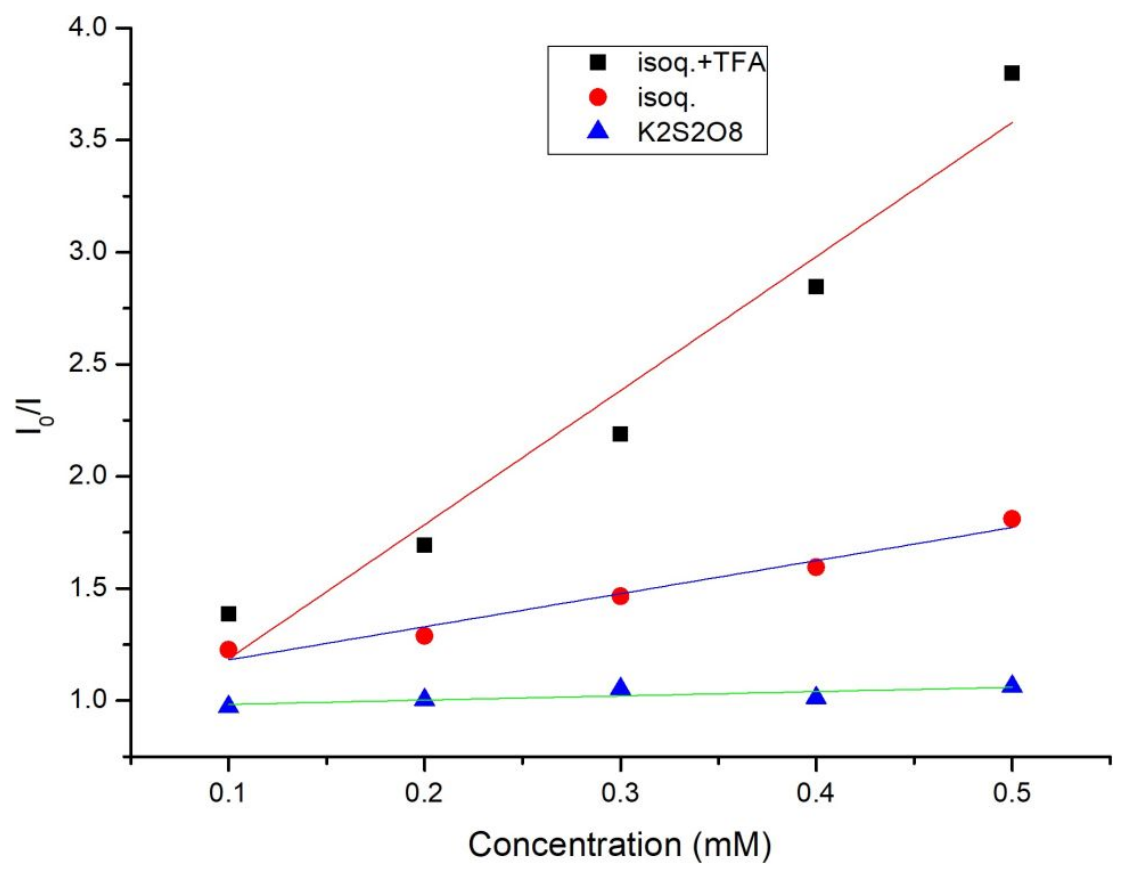

Figure S11. Stern-Volmer plots of $\operatorname{Ir}\left[\mathrm{dF}\left(\mathrm{CF}_{3}\right) \mathrm{ppy}\right]_{2}(\mathrm{dtbbpy}) \mathrm{PF}_{6}$ and three quenchers

\subsection{Cyclic Voltammetry Experiments}

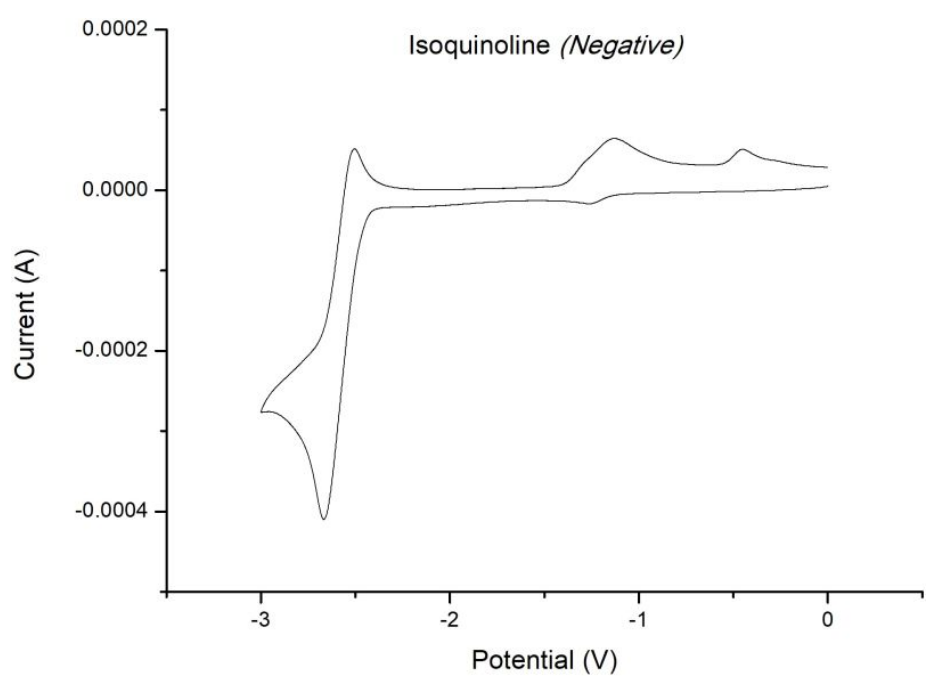

Figure S12. Cyclic Voltammetry curve of isoquinoline from 0 to $-3.0 \mathrm{~V}$ 


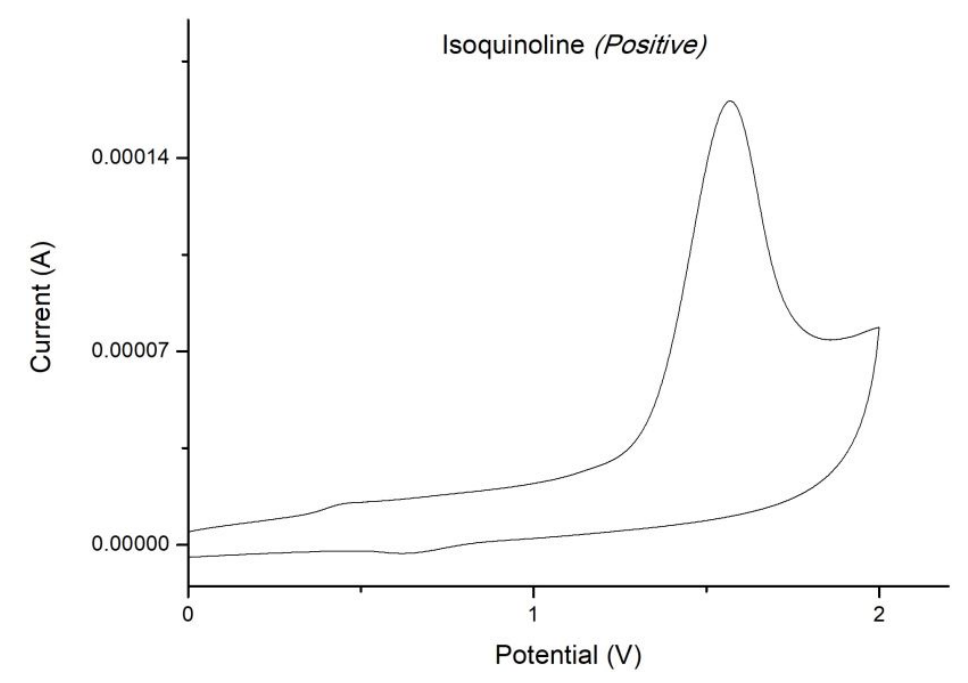

Figure S13. Cyclic Voltammetry curve of isoquinoline from 0 to $2.0 \mathrm{~V}$

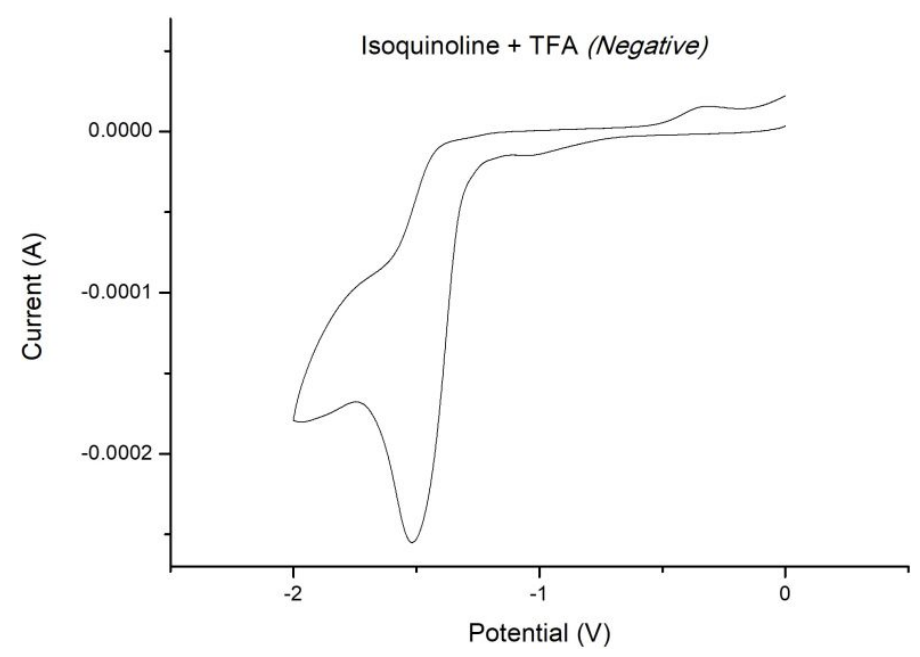

Figure S14. Cyclic Voltammetry curve of isoquinoline + TFA from 0 to $-2.0 \mathrm{~V}$

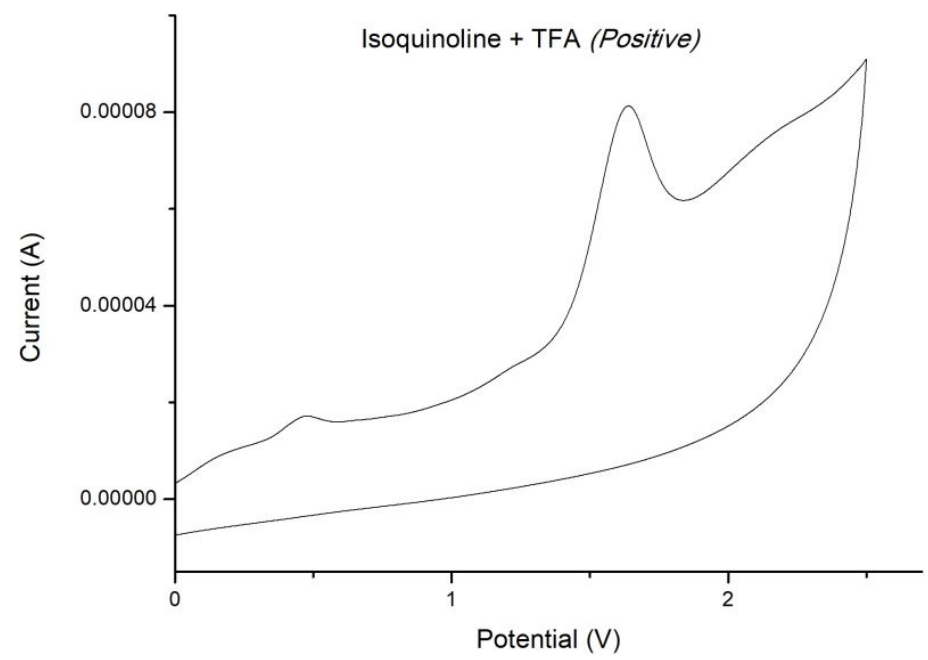

Figure S15. Cyclic Voltammetry curve of isoquinoline + TFA from 0 to $2.5 \mathrm{~V}$ 


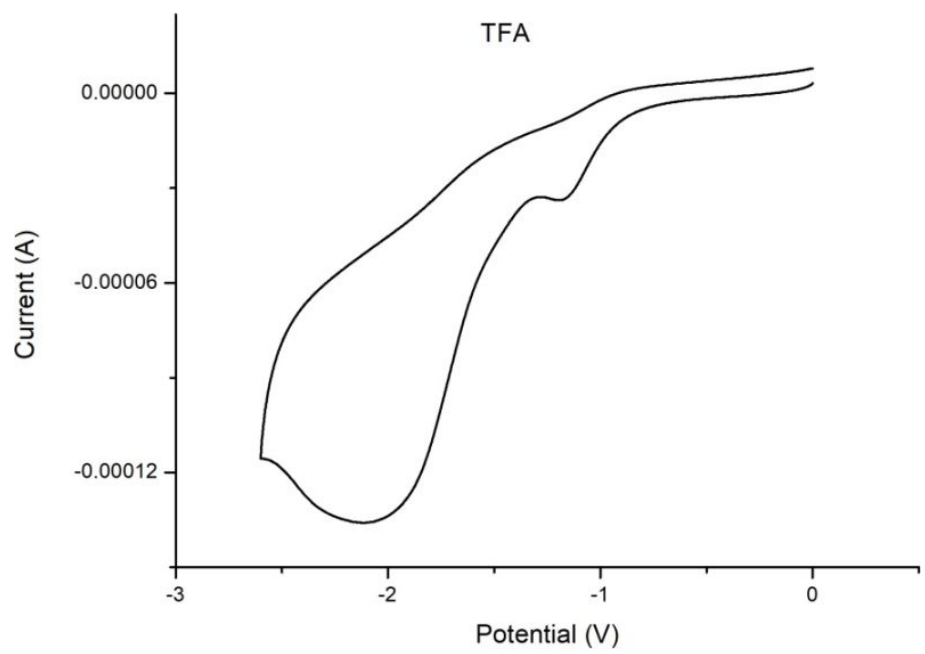

Figure S16. Cyclic Voltammetry curve of TFA

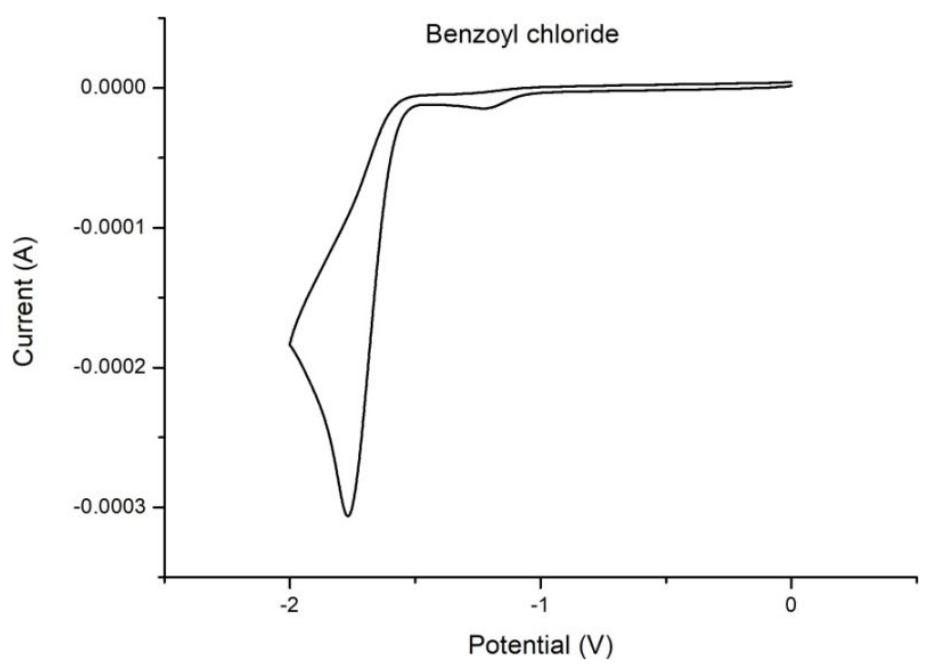

Figure S17. Cyclic Voltammetry curve of benzoyl chloride

Table S6. Half-wave potentials $\left(\mathrm{E}_{\mathrm{p} / 2}\right)$ of substrates

\begin{tabular}{|c|c|c|c|c|c|}
\hline entry & substrate & $\mathbf{E}$ & $\begin{array}{c}\mathrm{E}_{\mathrm{p}} / \mathrm{V} \\
\text { vs } \mathrm{AgNO}_{3} / \mathrm{Ag} \\
\end{array}$ & $\begin{array}{c}\mathrm{E}_{\mathrm{p} / 2} / \mathrm{V} \\
\text { vs } \mathrm{AgNO}_{3} / \mathrm{Ag}\end{array}$ & $\begin{array}{c}\mathbf{E}_{\mathbf{p} / 2} / \mathbf{V} \\
\text { vs SCE } \\
\end{array}$ \\
\hline 1 & \multirow{2}{*}{ isoquinoline } & $\mathrm{E}^{\mathrm{red}}$ & -2.669 & $-2.556\left(-2.51^{b}\right)$ & -2.258 \\
\hline 2 & & Ex. $^{\text {ox. }}$ & 1.568 & $1.414\left(1.55^{c}\right)$ & 1.712 \\
\hline 3 & isoquinoline & $\mathrm{E}^{\mathrm{red} .}$ & -1.518 & -1.379 & -1.081 \\
\hline 4 & $+\mathrm{TFA}$ & $\mathrm{E}^{\text {ox. }}$ & 1.639 & 1.438 & 1.736 \\
\hline 5 & TFA & $E^{\text {red }}$ & -2.116 & -1.626 & -1.328 \\
\hline 6 & benzoyl chloride & $E^{\text {red }}$ & -1.768 & -1.645 & -1.347 \\
\hline
\end{tabular}

Electroanal. Chem. 1974, 49, 111.

\subsection{Determination of Quantum Yield}




\section{Determination of light intensity at $420 \mathrm{~nm}$}

According to the procedure of Yoon, ${ }^{1}$ the photon flux of the LED was determined by standard ferrioxalate actinometry. ${ }^{2}$ A $0.15 \mathrm{M}$ solution of ferrioxalate was prepared by dissolving potassium ferrioxalate hydrate $(2.21 \mathrm{~g})$ in $\mathrm{H}_{2} \mathrm{SO}_{4}(30 \mathrm{~mL}$ of a $0.05 \mathrm{M}$ solution). A buffered solution of 1,10-phenanthroline was prepared by dissolving 1,10-phenanthroline (50 mg) and sodium acetate (11.25 g) in $\mathrm{H}_{2} \mathrm{SO}_{4}(25$ $\mathrm{mL}$ of a $0.5 \mathrm{M}$ solution). Both solutions were stored in the dark. To determine the photon flux of the LED, the ferrioxalate solution $(2.0 \mathrm{~mL})$ was placed in a cuvette and irradiated for $90 \mathrm{~s}$ at $\lambda_{\max }=420 \mathrm{~nm}$. After irradiation, the phenanthroline solution $(0.35 \mathrm{~mL})$ was added to the cuvette and the mixture was allowed to stir in the dark for $1 \mathrm{~h}$ to allow the ferrous ions to completely coordinate to the phenanthroline. The absorbance of the solution was measured at $510 \mathrm{~nm}$. A nonirradiated sample was also prepared and the absorbance at $510 \mathrm{~nm}$ was measured. Conversion was calculated using eq. 1.

$$
m o l \mathrm{Fe}^{2+}=\frac{V \cdot \Delta A}{l \cdot \varepsilon}
$$

where $V$ is the total volume $(0.00235 \mathrm{~L})$ of the solution after addition of phenanthroline, $\Delta A$ is the difference in absorbance at $510 \mathrm{~nm}$ between the irradiated and non-irradiated solutions, $l$ is the path length $(1.00 \mathrm{~cm})$, and $\varepsilon$ is the molar absorptivity of the ferrioxalate actinometer at $510 \mathrm{~nm}\left(11,100 \mathrm{~L} \cdot \mathrm{mol}^{-1} \cdot \mathrm{cm}^{-1}\right)$.

The photon flux can be calculated using eq. 2 .

$$
\text { photon flux }=\frac{m o l \mathrm{Fe}^{2+}}{\Phi \cdot t \cdot f}
$$

where $\Phi$ is the quantum yield for the ferrioxalate actinometer (1.12 at $\left.\lambda_{\mathrm{ex}}=420 \mathrm{~nm}\right), t$ is the irradiation time (90 s), and $f$ is the fraction of light absorbed at $\lambda_{\text {ex }}=420 \mathrm{~nm}$ by the ferrioxalate actinometer. This value is calculated using eq. 3 , where $A_{420 \mathrm{~nm}}$ is the absorbance of the ferrioxalate solution at $420 \mathrm{~nm}$.

$$
f=1-10^{-A_{420 \mathrm{~nm}}}
$$




$$
\begin{gathered}
m o l \mathrm{Fe}^{2+}=\frac{V \cdot \Delta A}{l \cdot \varepsilon}=\frac{0.00235 \mathrm{~L} \times 1.127}{1 \mathrm{~cm} \times 11,100 \mathrm{~L} \cdot \mathrm{mol}^{-1} \cdot \mathrm{cm}^{-1}}=2.39 \times 10^{-7} \mathrm{~mol} \\
f=1-10^{-A_{420 \mathrm{~nm}}}=1-10^{-2.403}=0.99605
\end{gathered}
$$

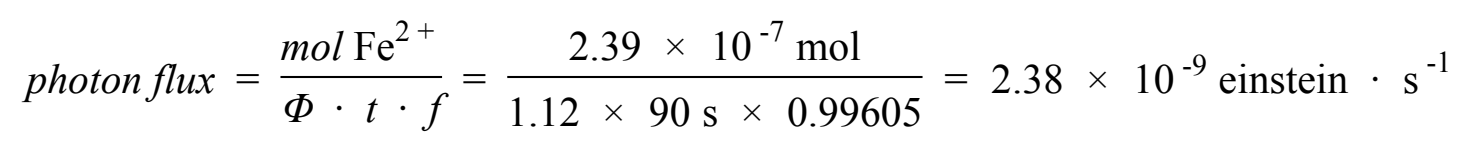

\section{Determination of the reaction quantum yield at $420 \mathrm{~nm}$}

PART A: Quantum yield of Minisci aroylation:

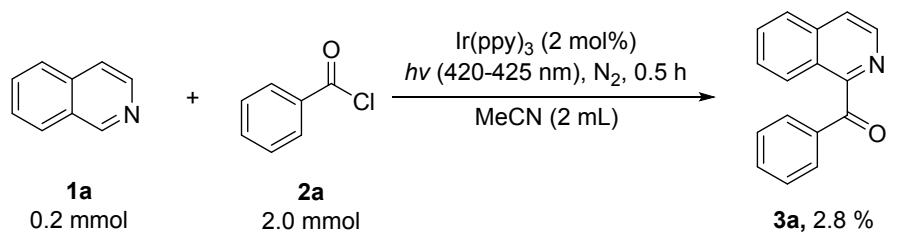

Isoquinoline 1a $(0.2 \mathrm{mmol})$, benzoyl chloride $\mathbf{2 a}$ (10.0 equiv.) were added to a solution of $\operatorname{Ir}(\mathrm{ppy})_{3}(2 \mathrm{~mol} \%)$ in $\mathrm{MeCN}(2 \mathrm{~mL})$ in a flame-dried $8 \mathrm{~mL}$ quartz tube at room temperature. The mixture was degassed by three cycles of freeze-pump-thaw. The mixture was stirred under nitrogen atmosphere at room temperature while irradiated by Parallel Light Reactor (WP-TEC-1020) at 420-425 nm for 30 minutes (1800 s). After irradiation, the yield of the product 3a was determined by GC-MS based on a 1,3,5-trimethoxybenzene standard and the final yield was $2.8 \%\left(5.6^{*} 10^{-6}\right.$ mol).

The reaction quantum yield was determined using eq. $\mathbf{4}$, where the photon flux is $2.38 \times 10^{-9} \mathrm{E} \mathrm{s}^{-1}$ (determined by actinometry as described above), $t$ is the reaction time (1800 s) and $f$ is the fraction of incident light absorbed by the reaction mixture, determined using eq. 3. An absorption spectrum of the reaction mixture gave an absorbance value of $>3$ at $420 \mathrm{~nm}$, indicating that essentially all the incident light (f $>$ $0.999)$ is absorbed by the photocatalyst.

$$
\Phi_{\text {reaction }}=\frac{\text { mol of product }}{\text { photon flux } \cdot t \cdot f}
$$

The reaction quantum yield was thus determined to be 1.17 . 
PART B: Quantum yield of Minisci alkylation:

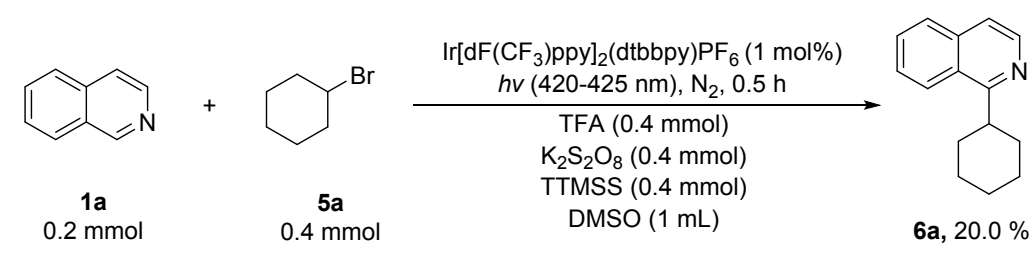

Isoquinoline 1a $(0.2 \mathrm{mmol})$, bromocyclohexane 5a (2.0 equiv.), trifluoroacetic acid (2.0 equiv.), $\mathrm{K}_{2} \mathrm{~S}_{2} \mathrm{O}_{8}$ (2.0 equiv.), TTMSS (2.0 equiv.) were added to a solution of $\operatorname{Ir}\left[\mathrm{dF}\left(\mathrm{CF}_{3}\right) \text { ppy }\right]_{2}(\mathrm{dtbbpy}) \mathrm{PF}_{6}(2 \mathrm{~mol} \%)$ in DMSO $(1 \mathrm{~mL})$ in a flame-dried $8 \mathrm{~mL}$ quartz tube at room temperature. The mixture was degassed by three cycles of freeze-pump-thaw. The mixture was stirred under nitrogen atmosphere at room temperature while irradiated by Parallel Light Reactor (WP-TEC-1020) at 420-425 $\mathrm{nm}$ for 30 minutes $(1800 \mathrm{~s})$. After irradiation, the yield of the product 6a was determined by GC-MS based on a 1,3,5-trimethoxybenzene standard and the final yield was $20 \%\left(4.0 * 10^{-5} \mathrm{~mol}\right)$.

The reaction quantum yield was thus determined to be 9.34 according to eq. 4 described above. 


\section{References}

(1) Cismesia, M. A.; Yoon, T. P. Characterizing Chain Processes in Visible Light Photoredox Catalysis. Chem. Sci. 2015, 6, 5426-5434.

(2) (a) Hatchard, C. G.; Parker, C. A. A New Sensitive Chemical Actinometer - II. Potassium Ferrioxalate as a Standard Chemical Actinometer Proc. Roy. Soc. A 1956, 235, 518-536. (b) Kuhn, H. J.; Braslavsky, S. E.; Schmidt, R. Chemical actinometry (IUPAC Technical Report). Pure Appl. Chem. 2004, 76, 2105-2146. (c) Monalti, M.; Credi, A.; Prodi, L.; Gandolfi, M. T. Chemical Actinometry. Handbook of Photochemistry, 3rd Ed. Taylor \& Francis Group, LLC. Boca Raton, FL 2006, 601. 


\section{NMR Spectra of Compounds}

isoquinolin-1-yl(phenyl)methanone (3a)

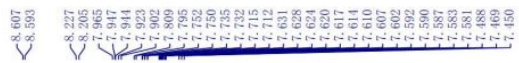

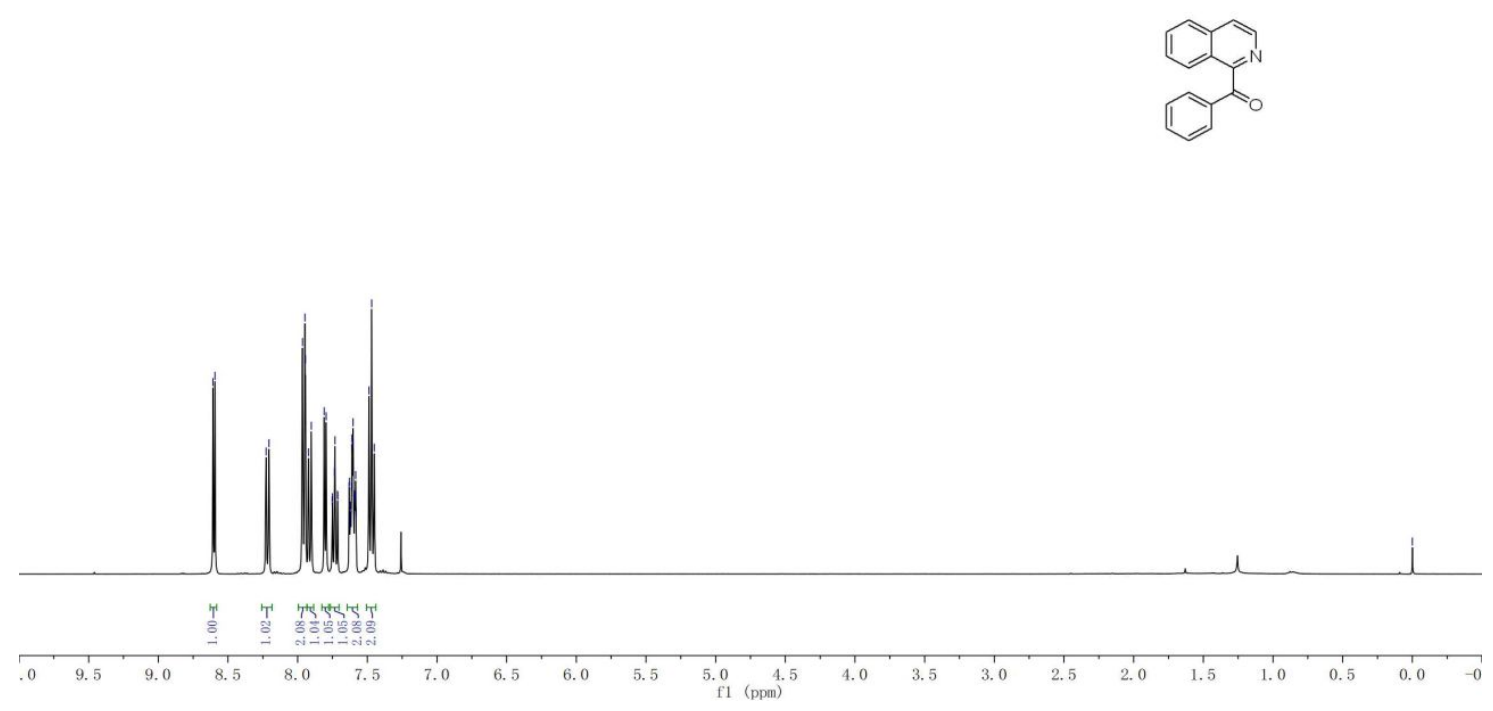

Figure S18. ${ }^{1} \mathrm{H}$ NMR Spectra of 3a

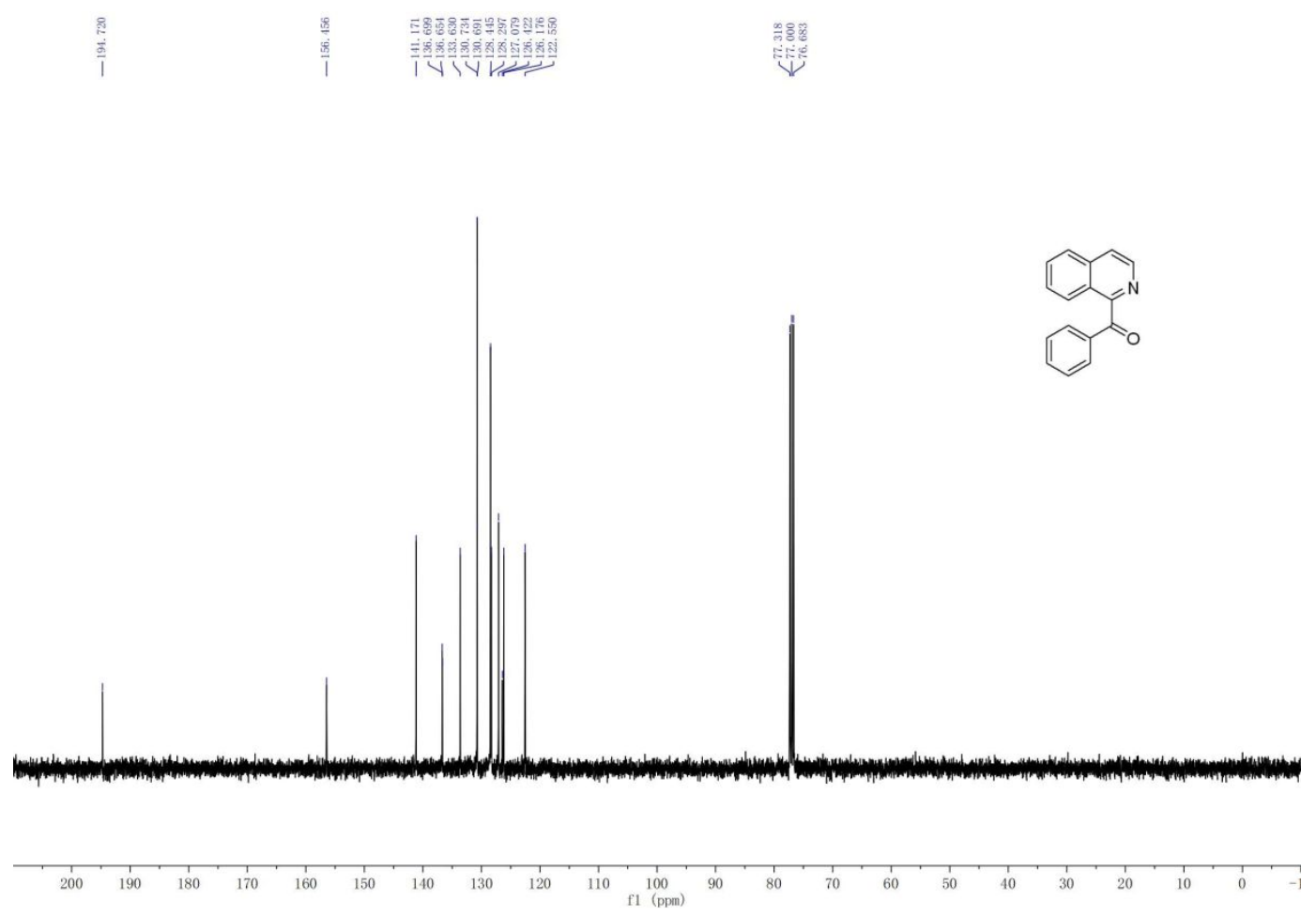

Figure S19. ${ }^{13} \mathrm{C}$ NMR Spectra of $\mathbf{3 a}$ 
(4-fluorophenyl)(isoquinolin-1-yl)methanone (3b)

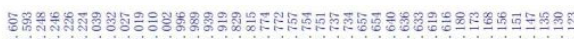

๖ 
(4-chlorophenyl)(isoquinolin-1-yl)methanone (3c)

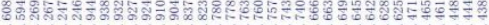

Y

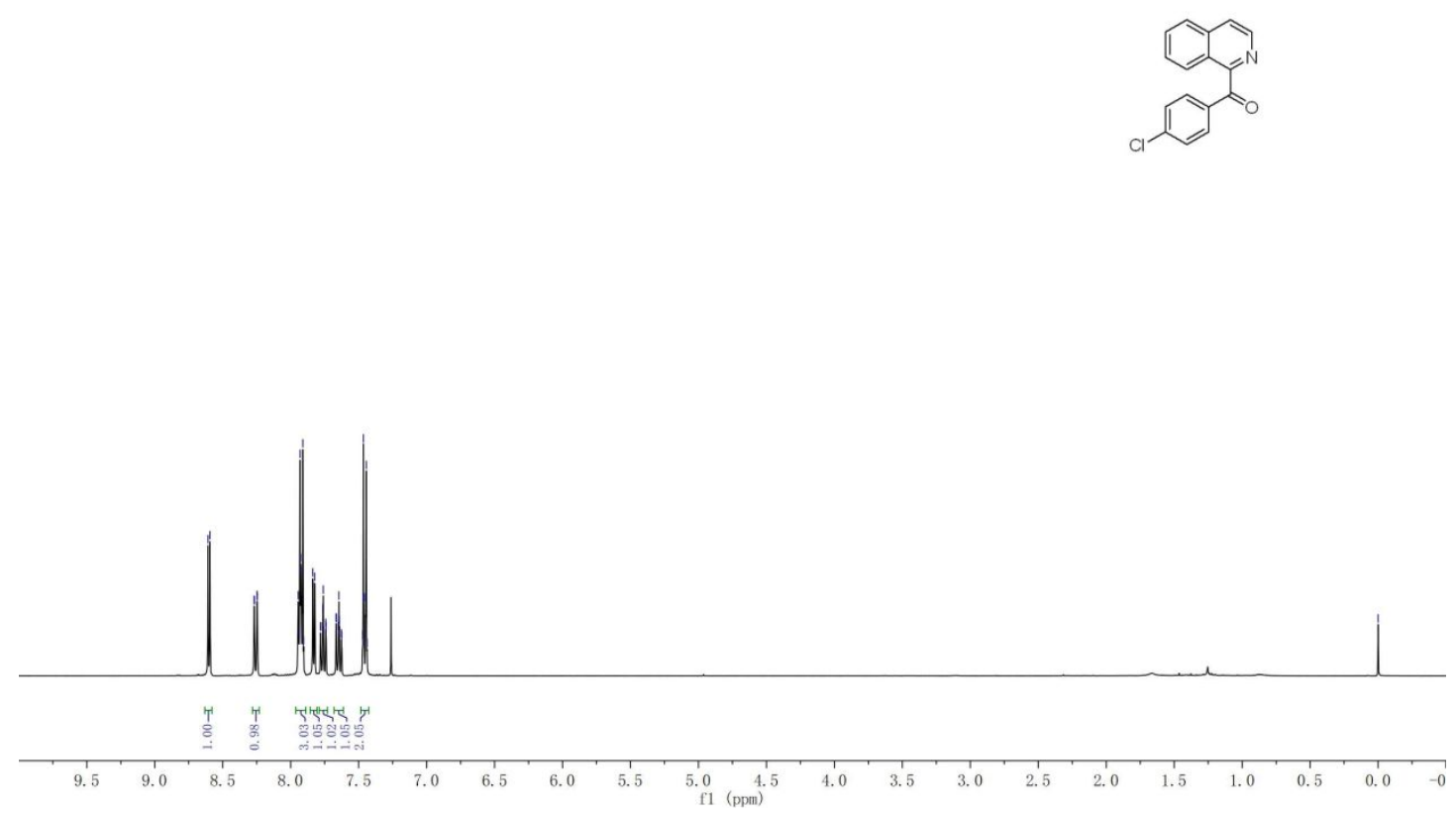

Figure S22. ${ }^{1} \mathrm{H}$ NMR Spectra of 3c

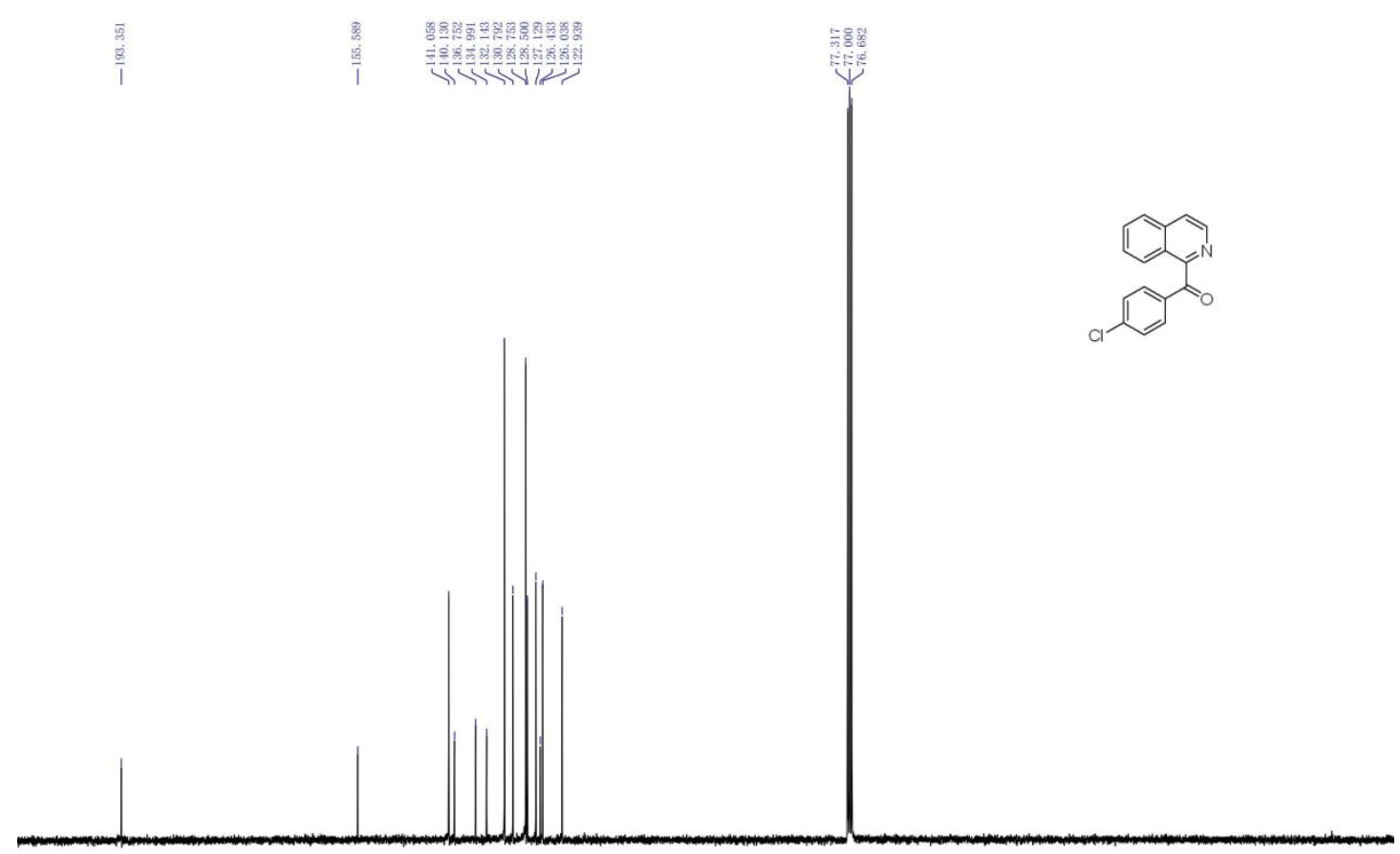

$200 \quad 190 \quad \frac{1}{180}+\frac{1}{1}+\frac{1}{1}+\frac{1}{1}$

Figure S23. ${ }^{13} \mathrm{C}$ NMR Spectra of 3c 
(4-bromophenyl)(isoquinolin-1-yl)methanone (3d)

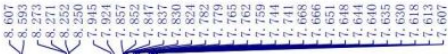
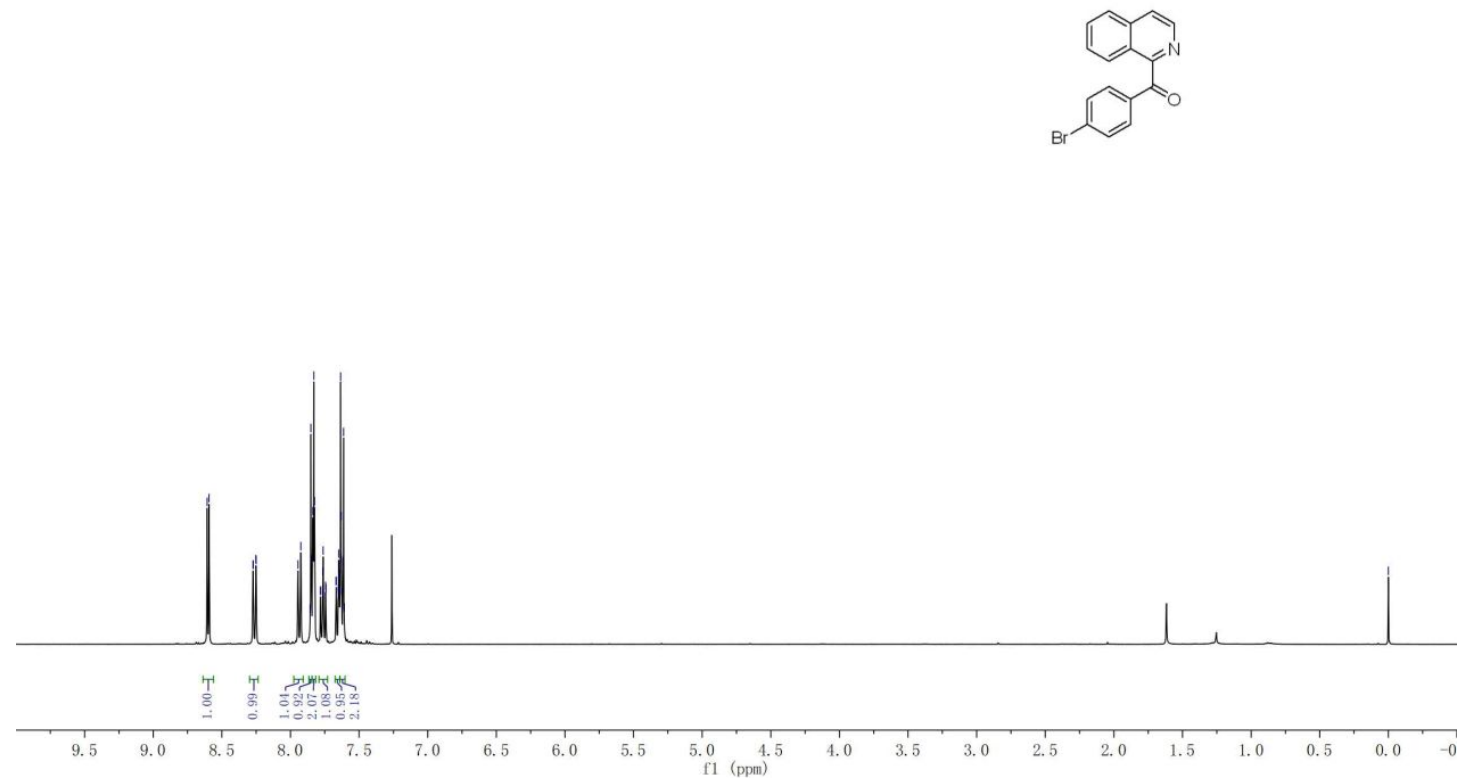

Figure S24. ${ }^{1} \mathrm{H}$ NMR Spectra of 3d

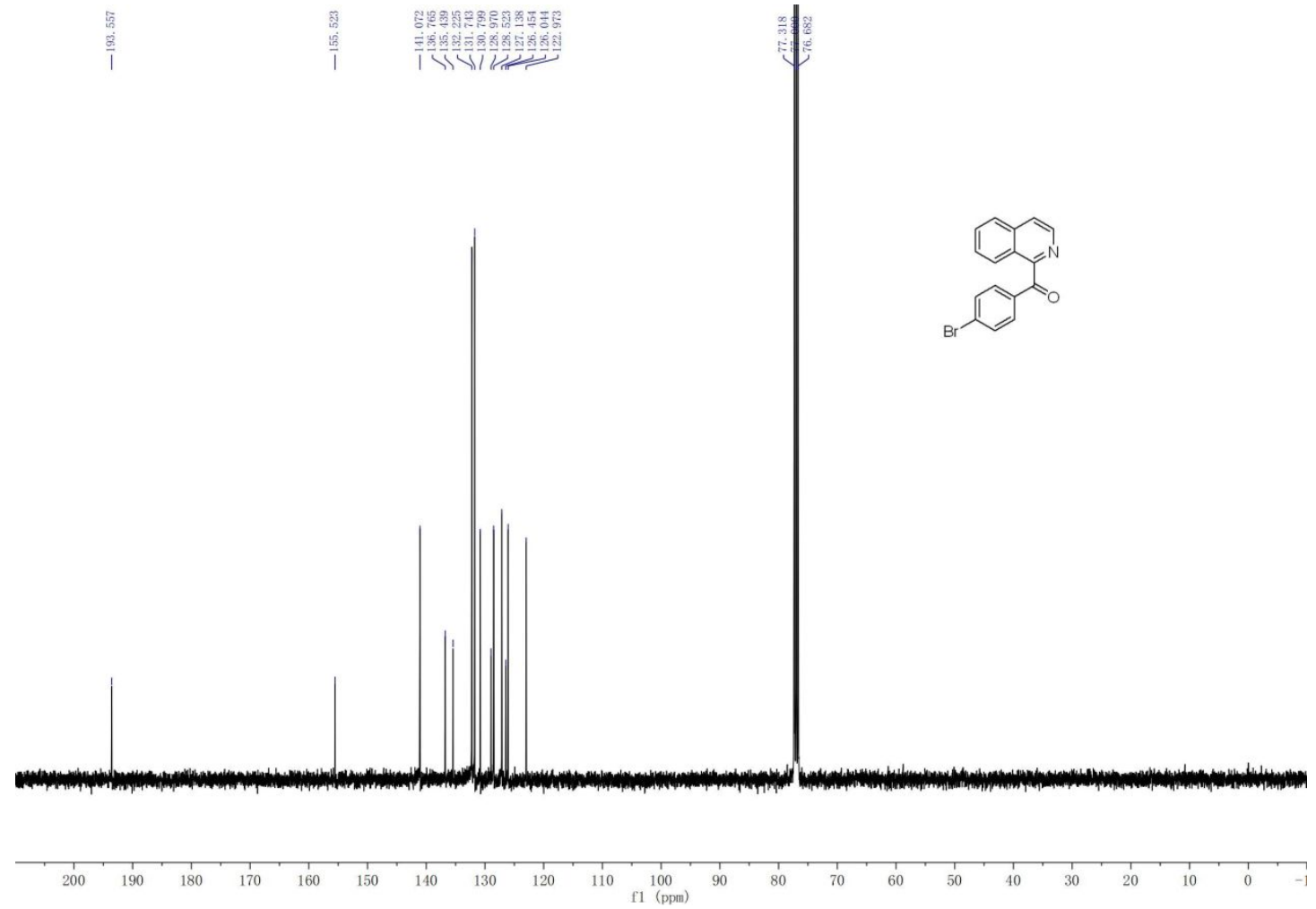

Figure S25. ${ }^{13} \mathrm{C}$ NMR Spectra of $\mathbf{3 d}$ 
isoquinolin-1-yl(4-(trifluoromethyl)phenyl)methanone (3e)

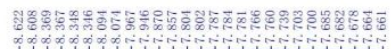

บ4

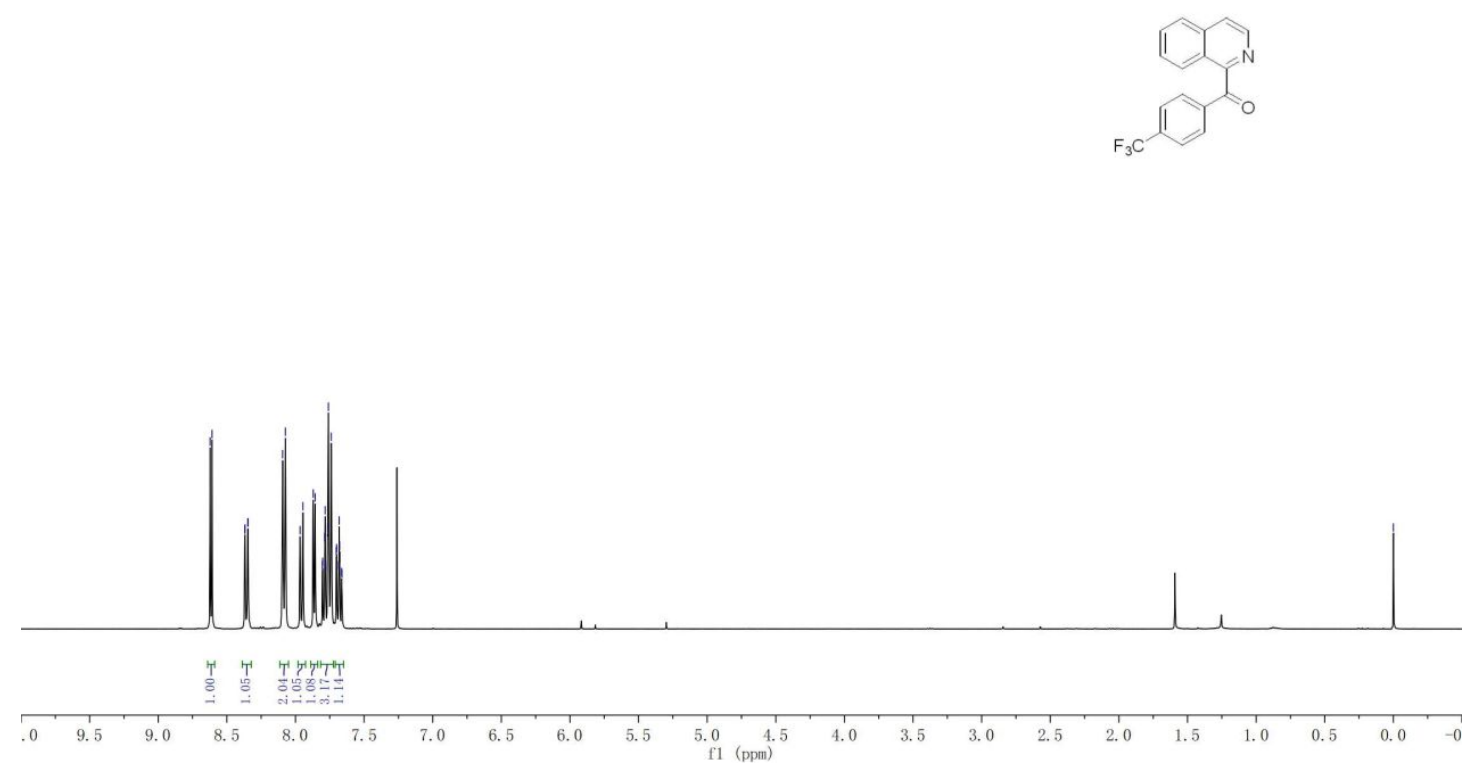

Figure S26. ${ }^{1} \mathrm{H}$ NMR Spectra of $\mathbf{3 e}$

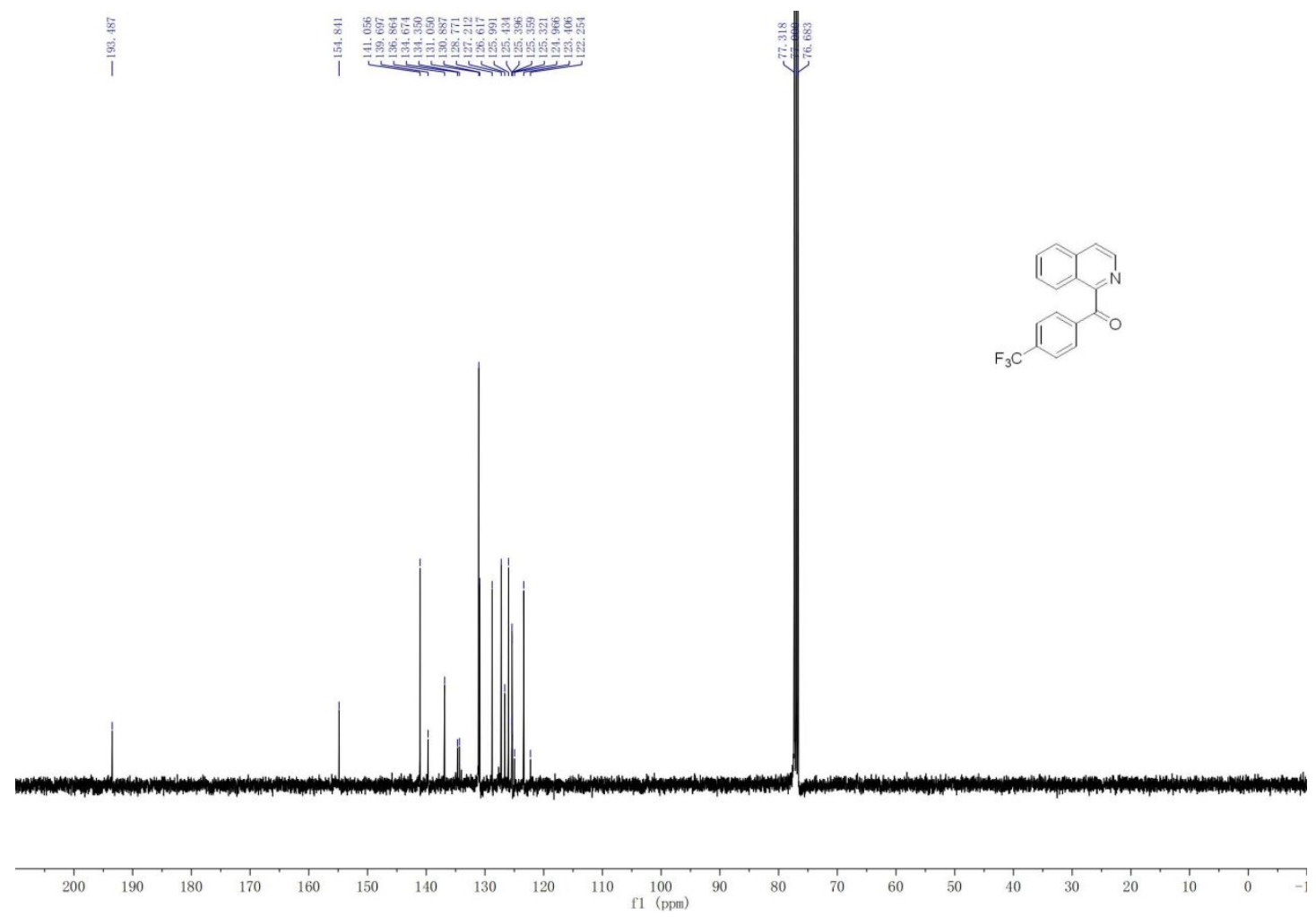

Figure S27. ${ }^{13} \mathrm{C}$ NMR Spectra of $\mathbf{3 e}$ 
isoquinolin-1-yl(p-tolyl)methanone (3f)

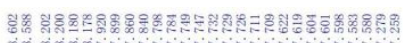

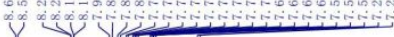
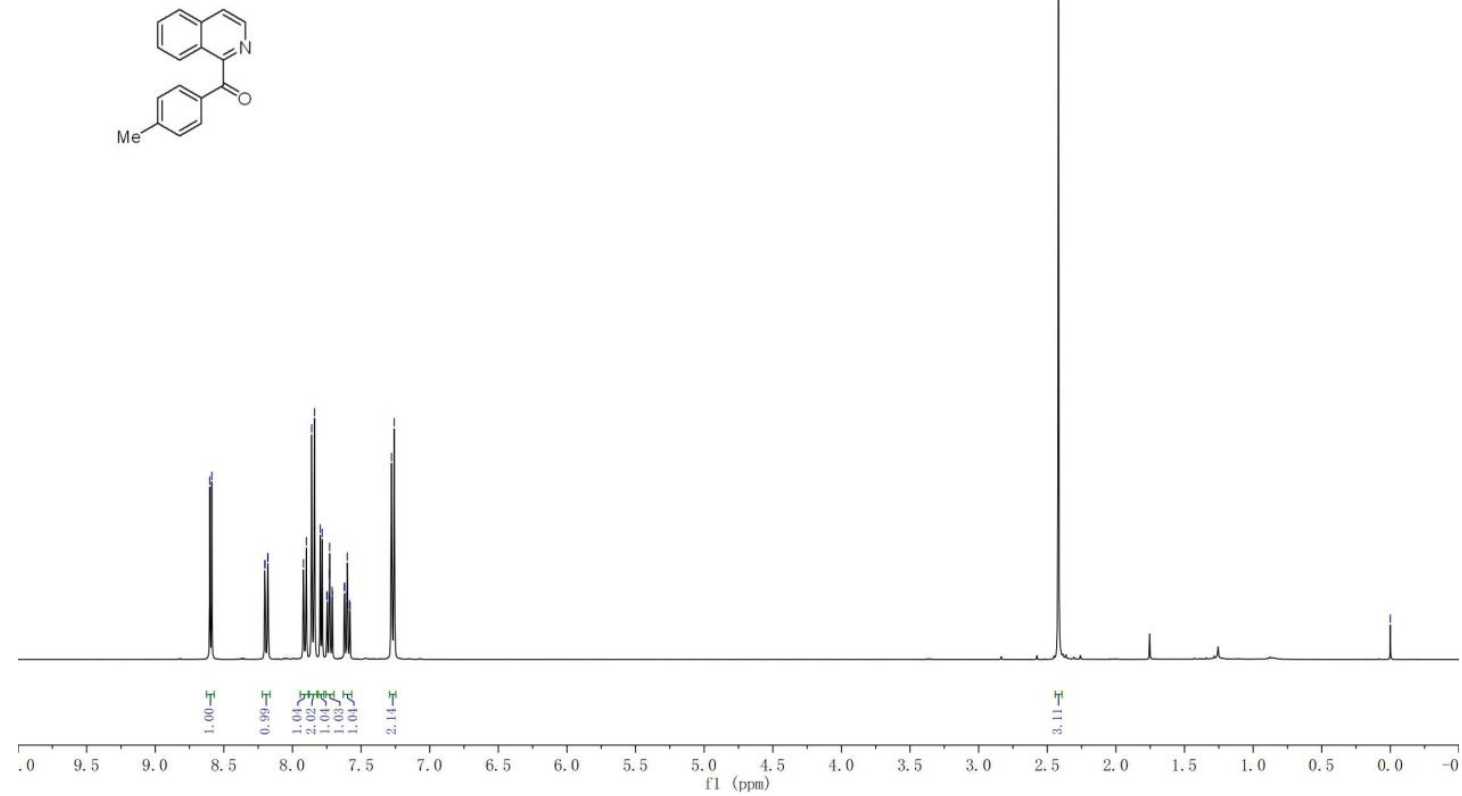

Figure S28. ${ }^{1} \mathrm{H}$ NMR Spectra of $\mathbf{3 f}$
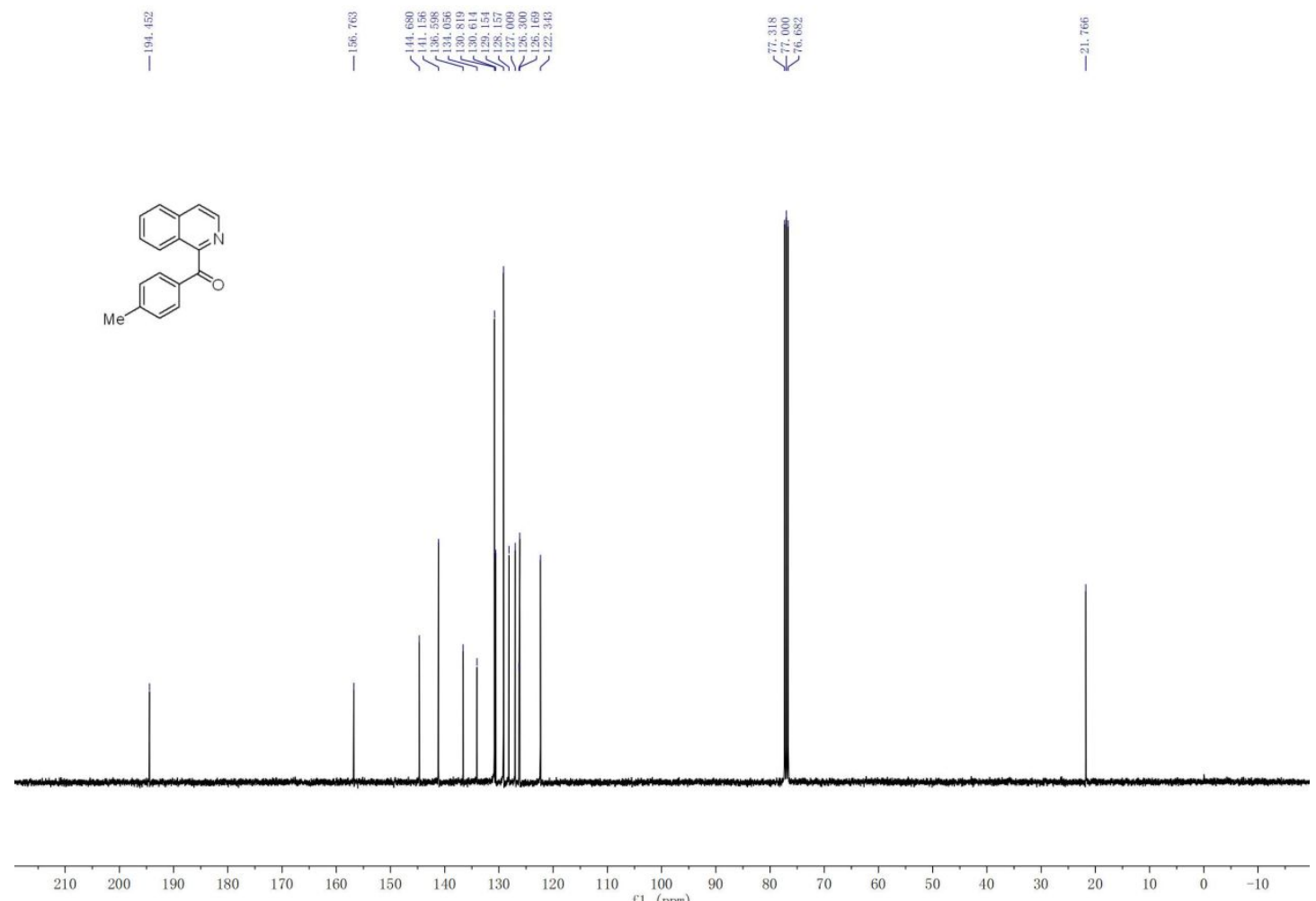

Figure S29. ${ }^{13} \mathrm{C}$ NMR Spectra of $\mathbf{3 f}$ 
(4-(tert-butyl)phenyl)(isoquinolin-1-yl)methanone (3g)

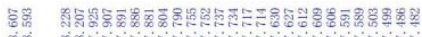

事
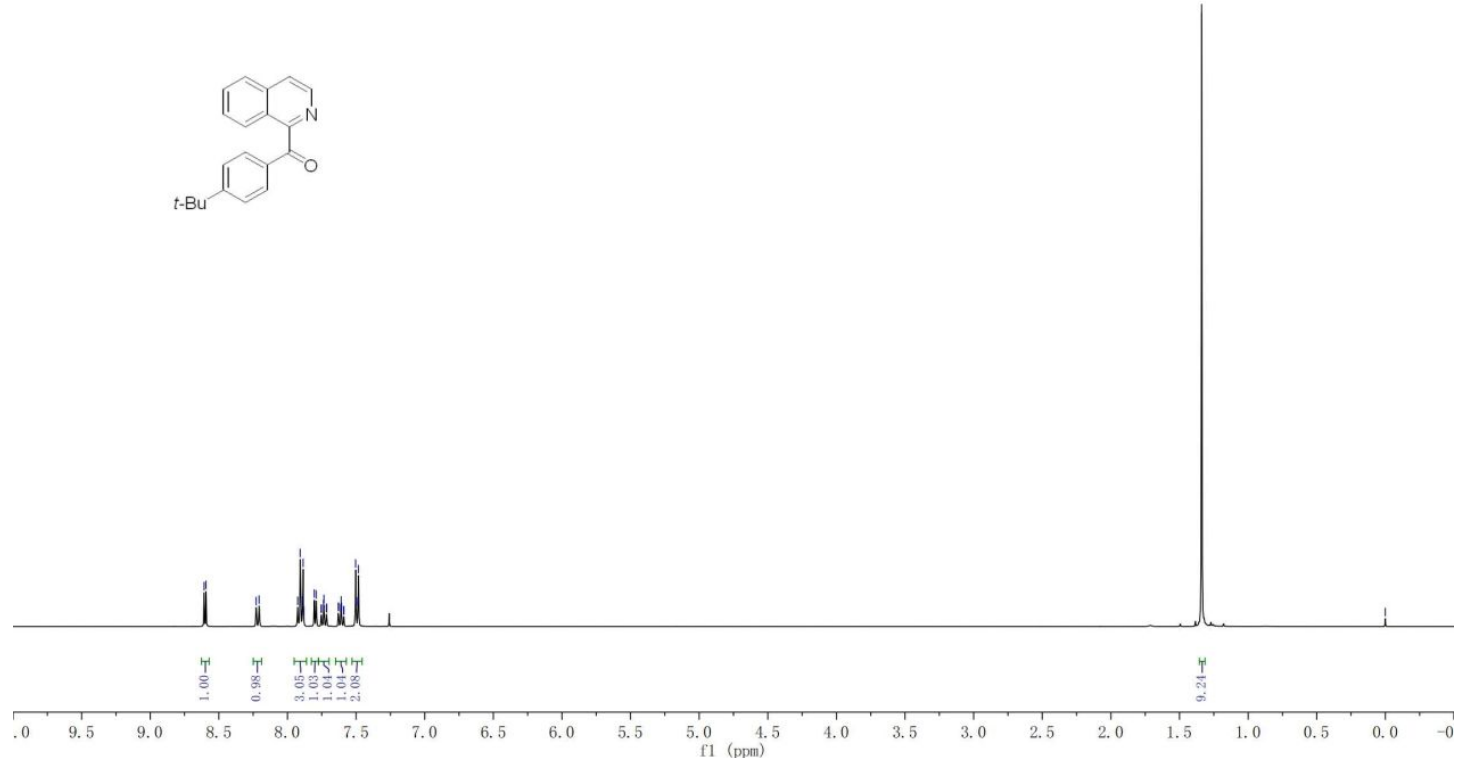

Figure S30. ${ }^{1} \mathrm{H}$ NMR Spectra of $\mathbf{3 g}$
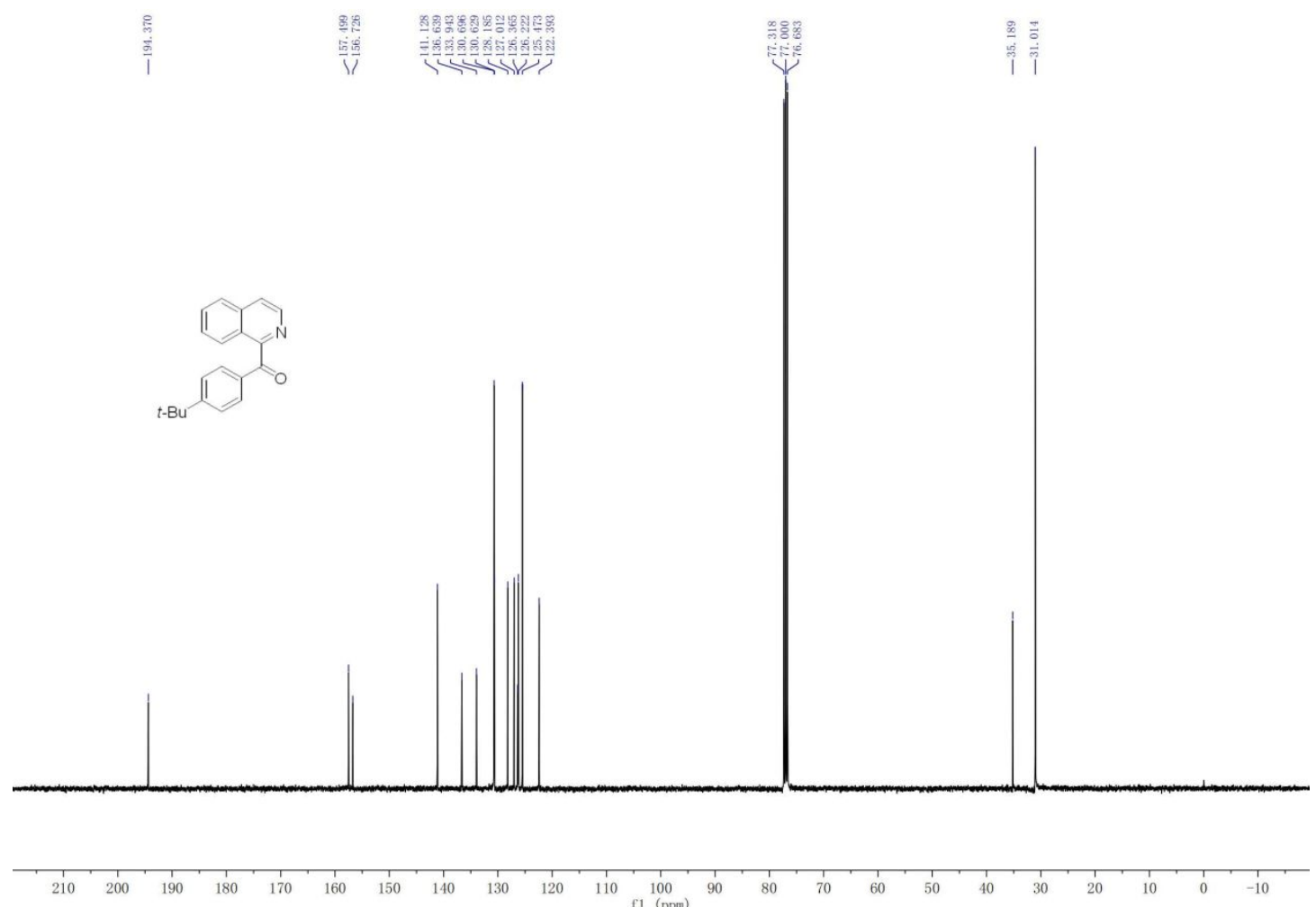

Figure S31. ${ }^{13} \mathrm{C}$ NMR Spectra of $\mathbf{3 g}$ 
isoquinolin-1-yl(o-tolyl)methanone (3h)

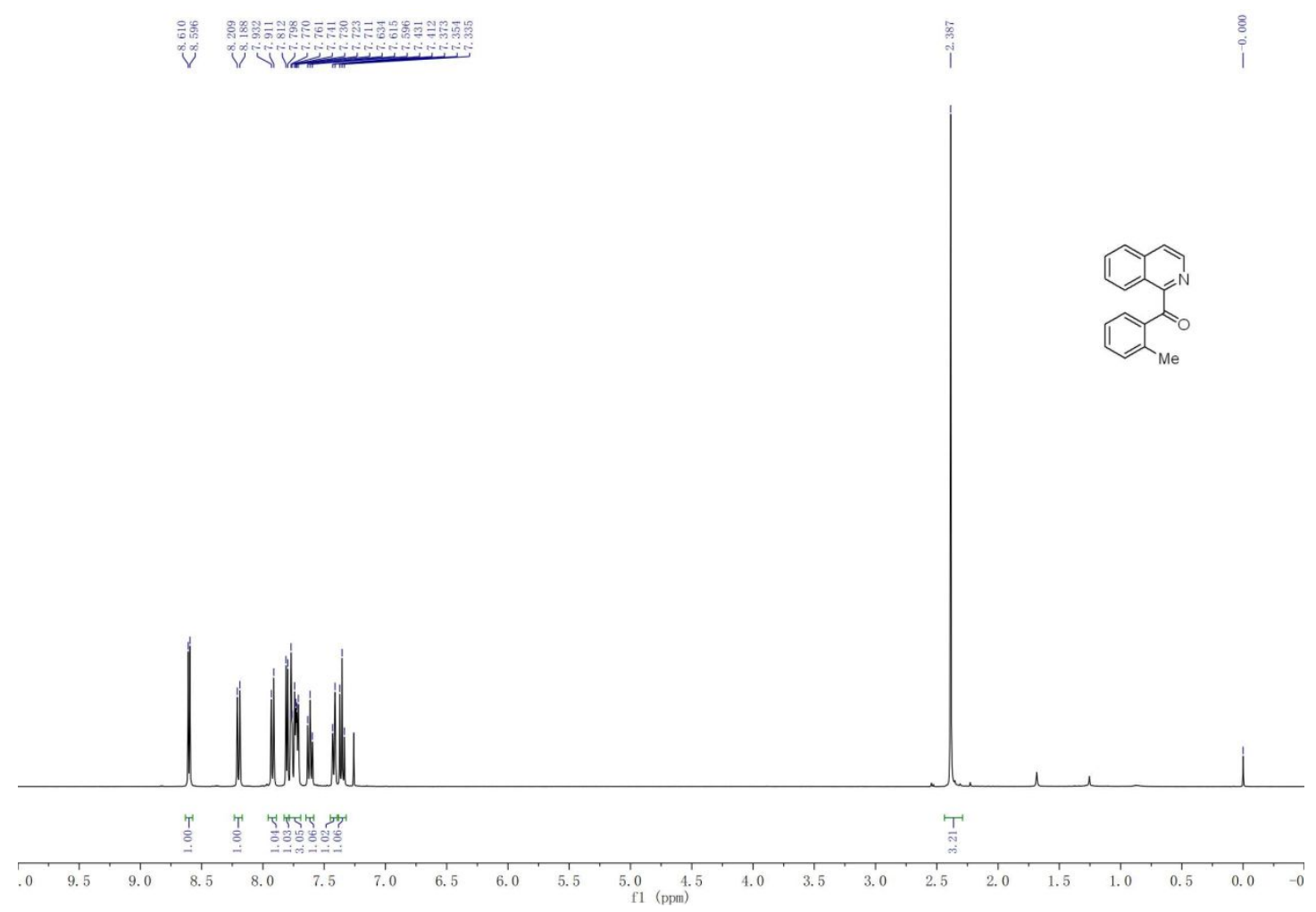

Figure S32. ${ }^{1} \mathrm{H}$ NMR Spectra of $\mathbf{3 h}$

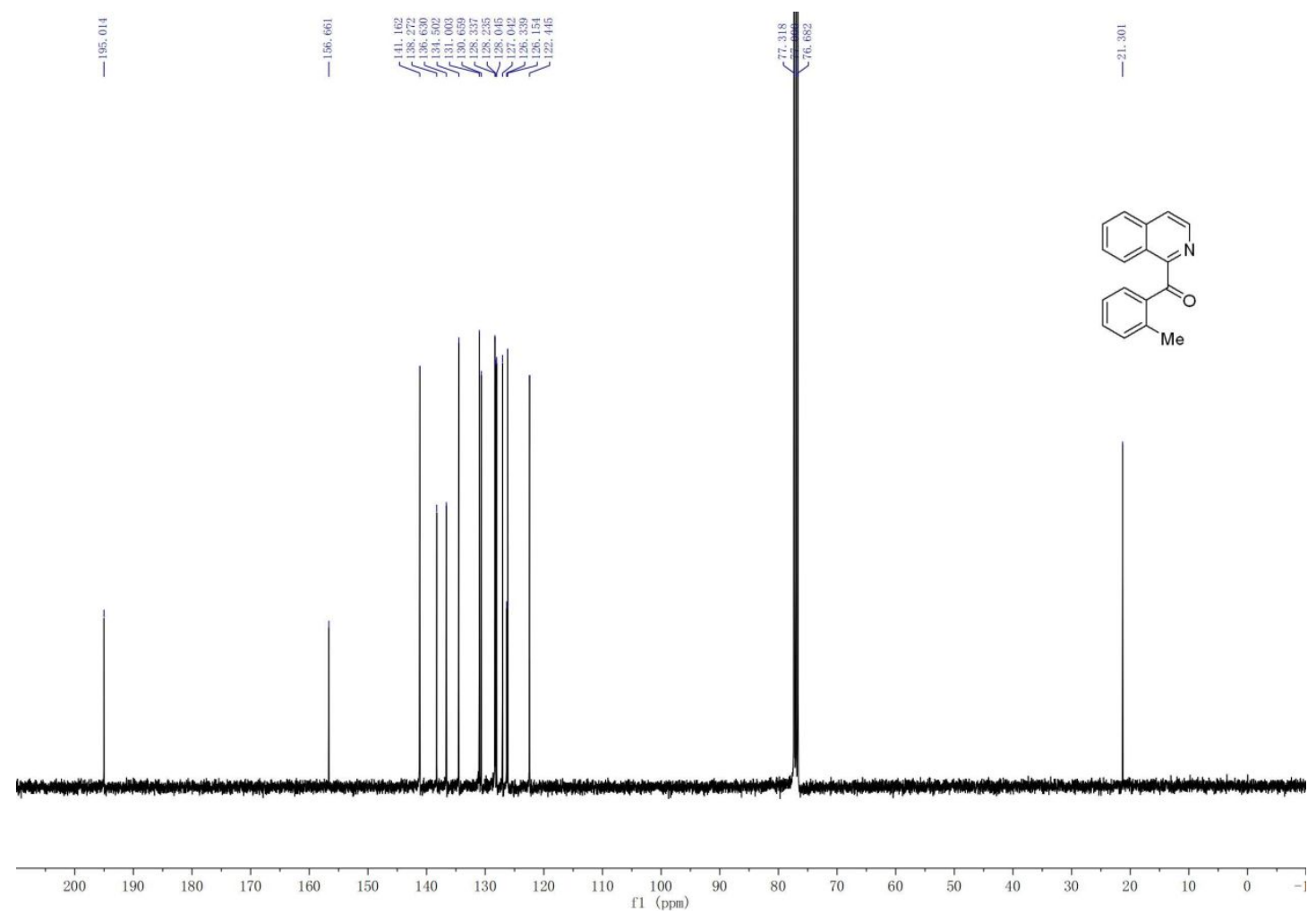

Figure S33. ${ }^{13} \mathrm{C}$ NMR Spectra of $\mathbf{3 h}$ 
(2-chlorophenyl)(isoquinolin-1-yl)methanone (3i)

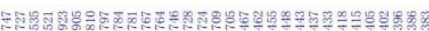

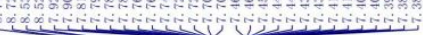

(1)

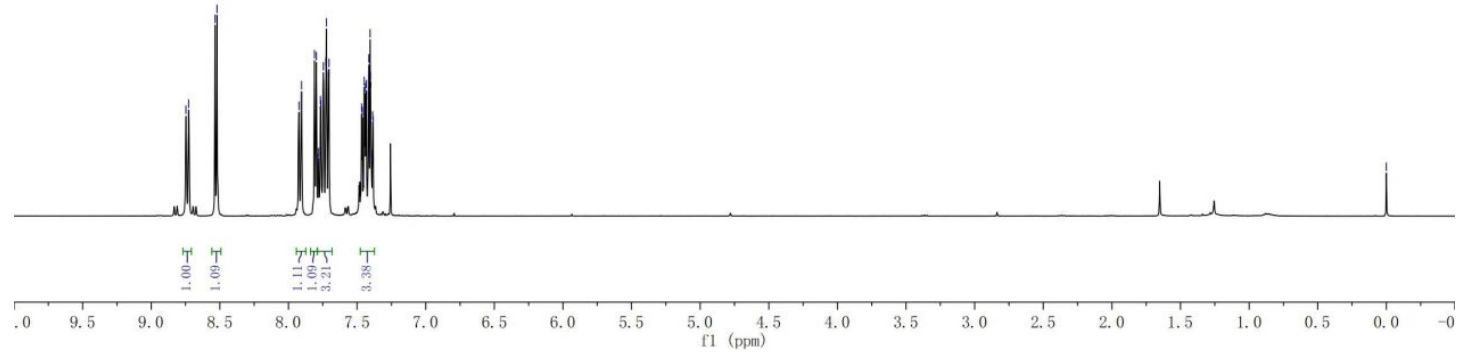

Figure S34. ${ }^{1} \mathrm{H}$ NMR Spectra of $\mathbf{3 i}$

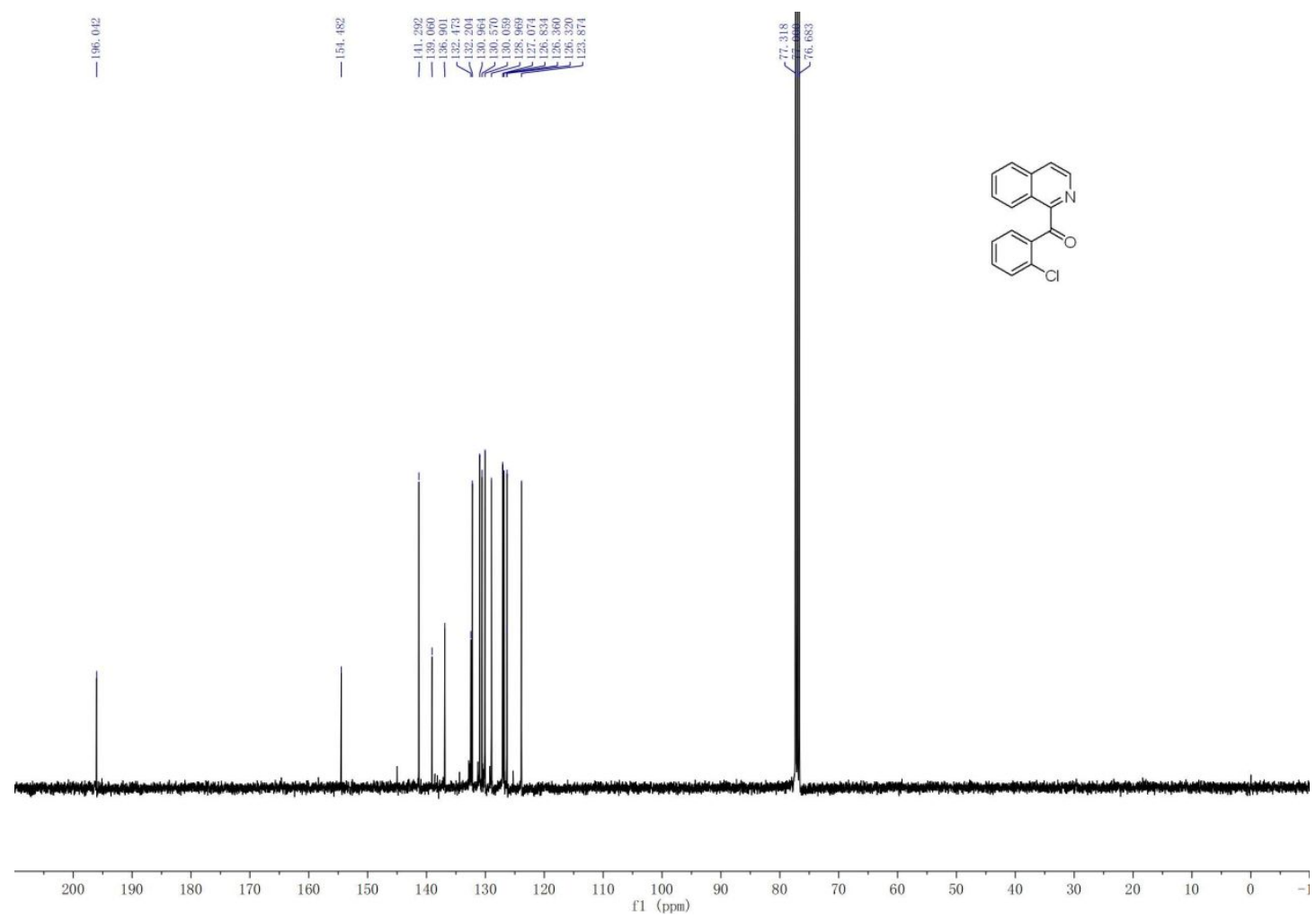

Figure S35. ${ }^{13} \mathrm{C}$ NMR Spectra of $\mathbf{3 i}$ 
isoquinolin-1-yl(m-tolyl)methanone (3j)

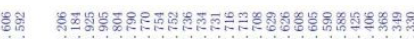

vo

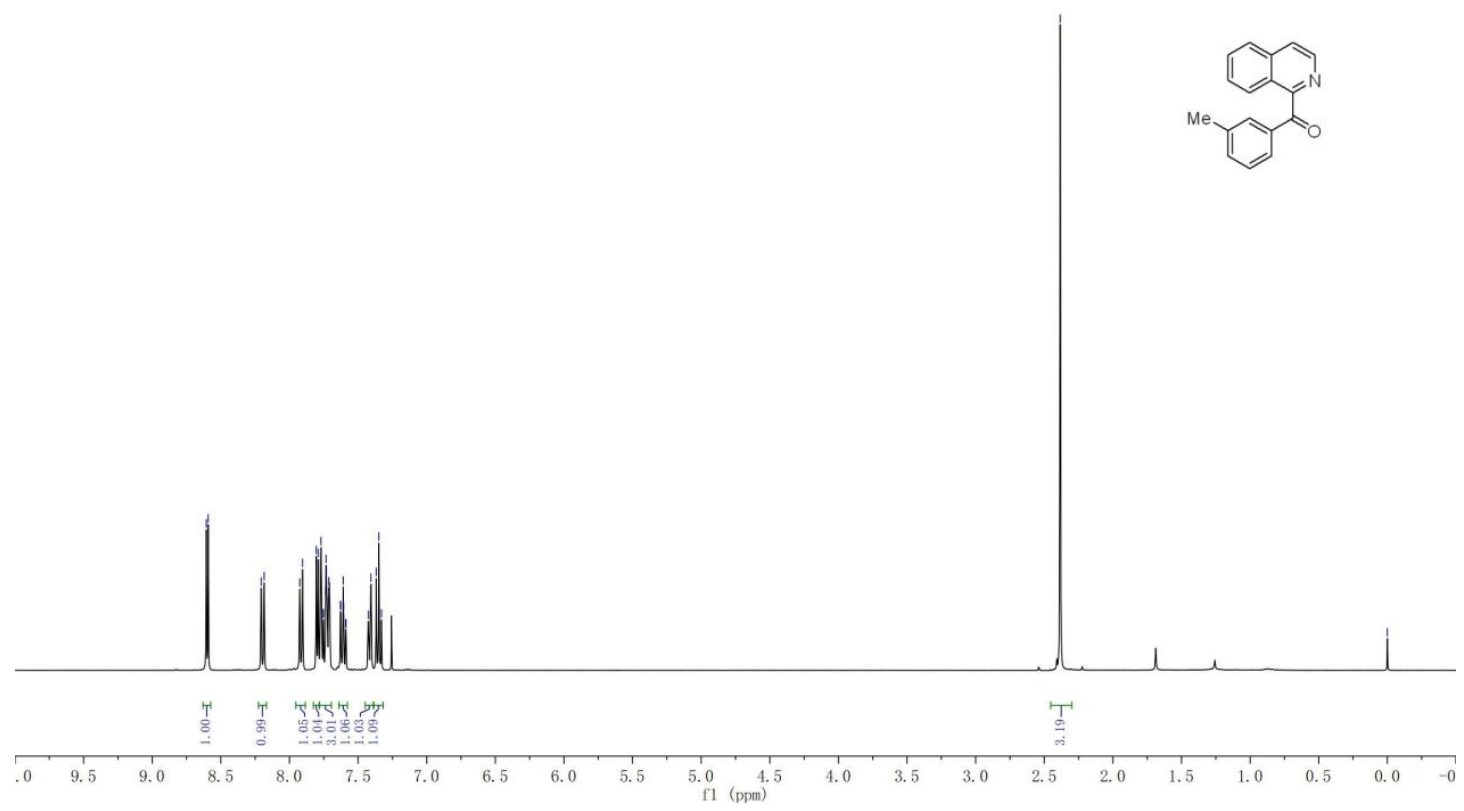

Figure S36. ${ }^{1} \mathrm{H}$ NMR Spectra of $\mathbf{3 j}$

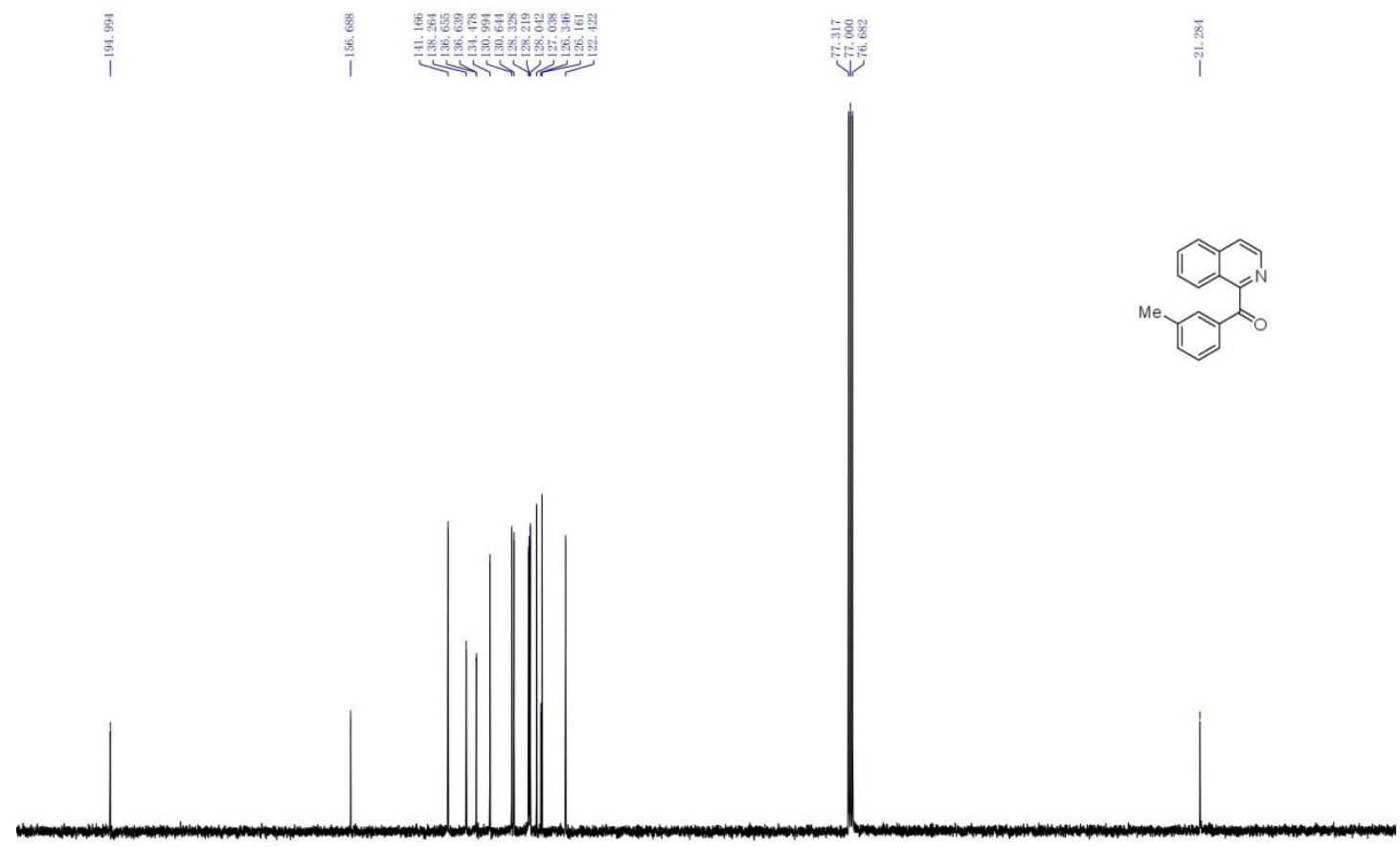

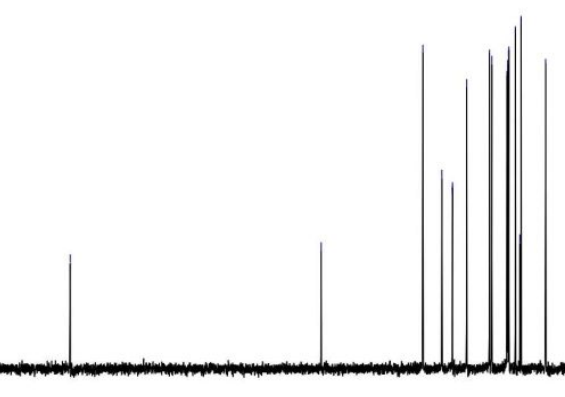

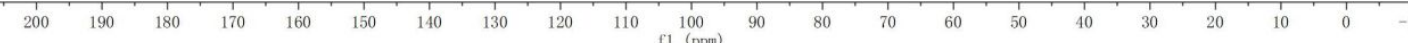

Figure S37. ${ }^{13} \mathrm{C}$ NMR Spectra of $\mathbf{3 j}$ 


\section{(3-chlorophenyl)(isoquinolin-1-yl)methanone (3k)}
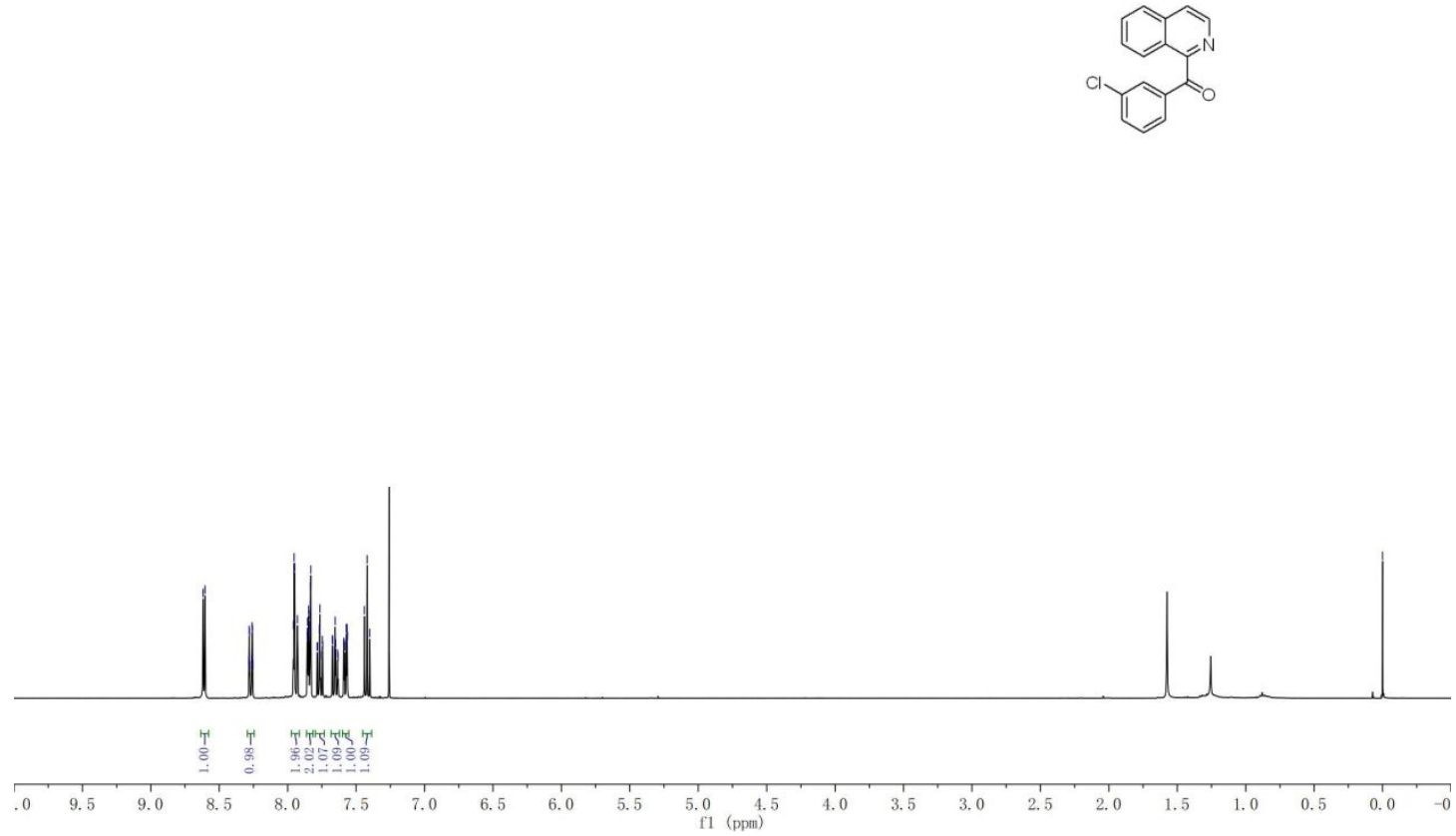

Figure S38. ${ }^{1} \mathrm{H}$ NMR Spectra of $\mathbf{3 k}$

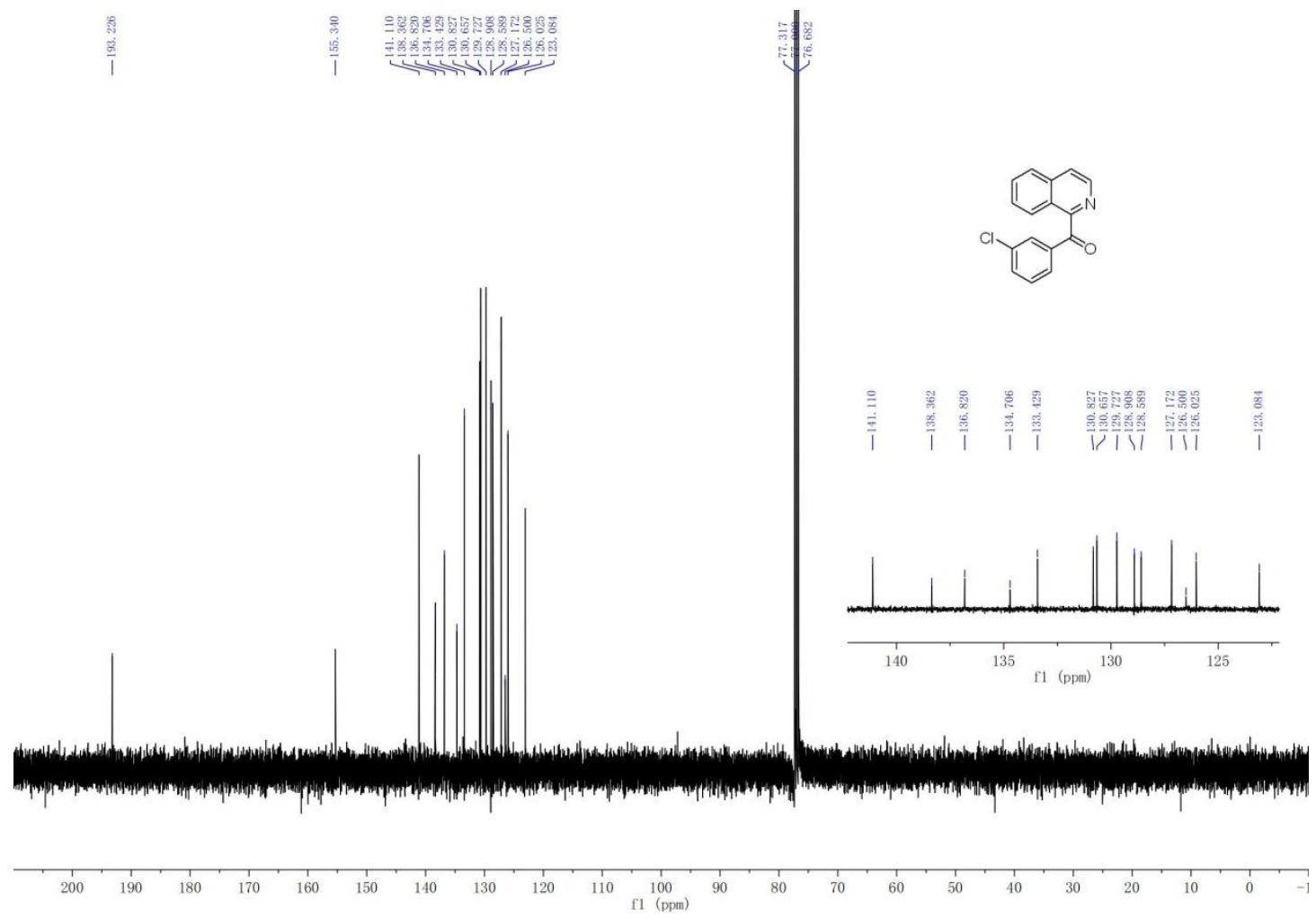

Figure S39. ${ }^{13} \mathrm{C}$ NMR Spectra of $\mathbf{3 k}$ 


\section{(3,5-dimethylphenyl)(isoquinolin-1-yl)methanone (3I)}

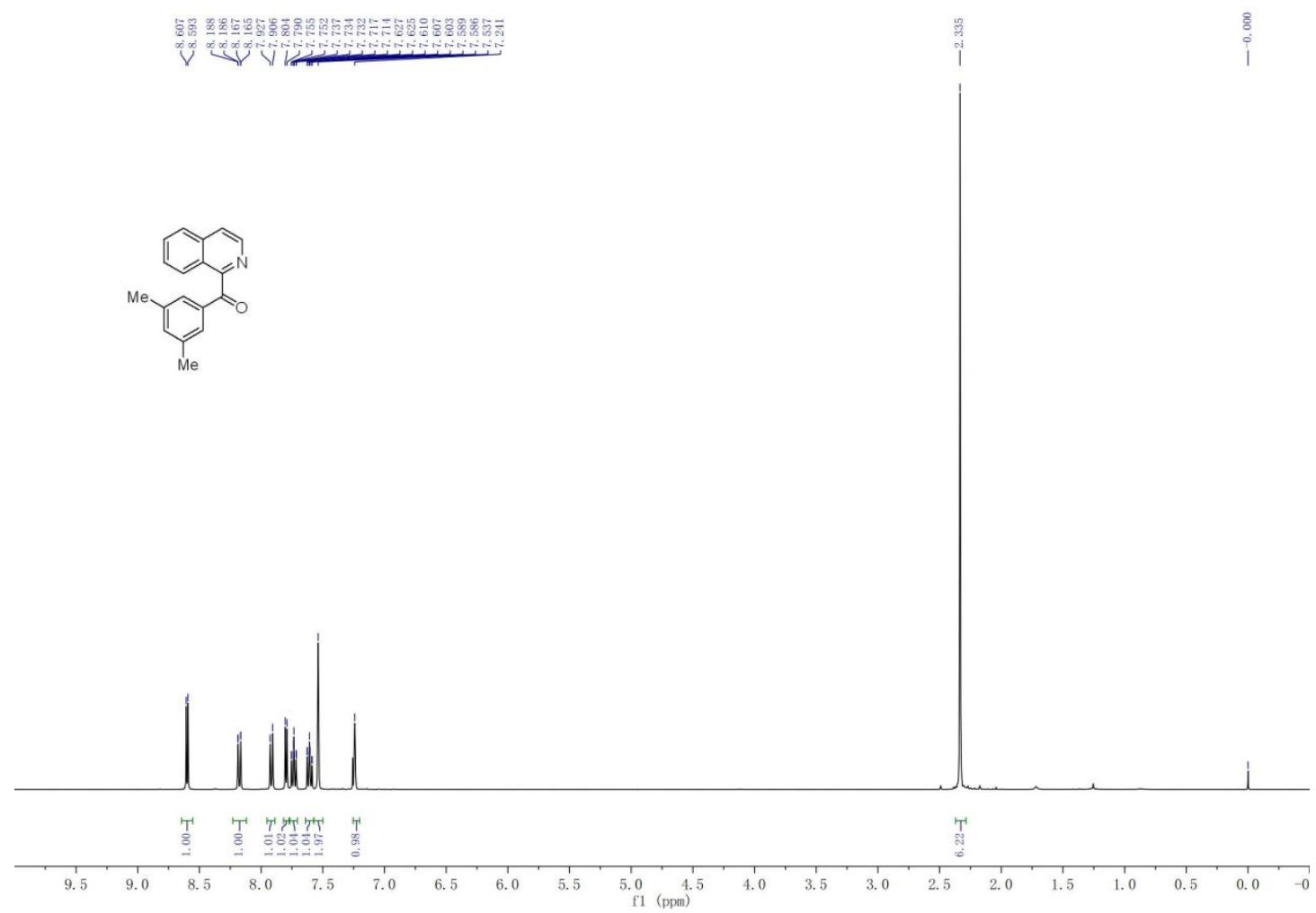

Figure S40. ${ }^{1} \mathrm{H}$ NMR Spectra of $\mathbf{3 I}$
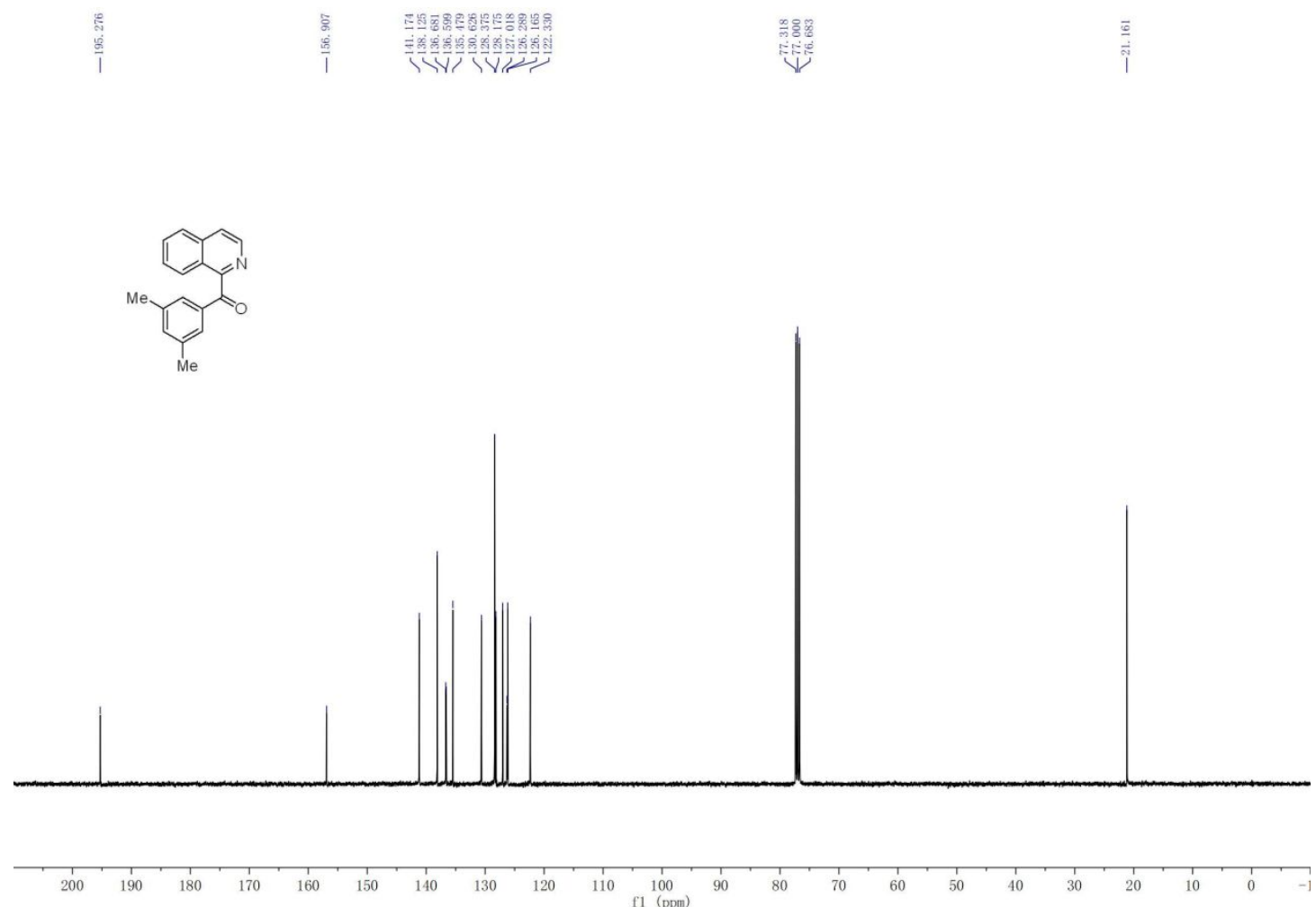

Figure S41. ${ }^{13} \mathrm{C}$ NMR Spectra of $\mathbf{3 1}$ 


\section{(3,4-dichlorophenyl)(isoquinolin-1-yl)methanone (3m)}

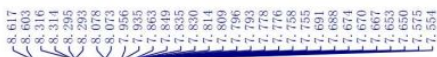

20
$\vdots$
0
0
0
1
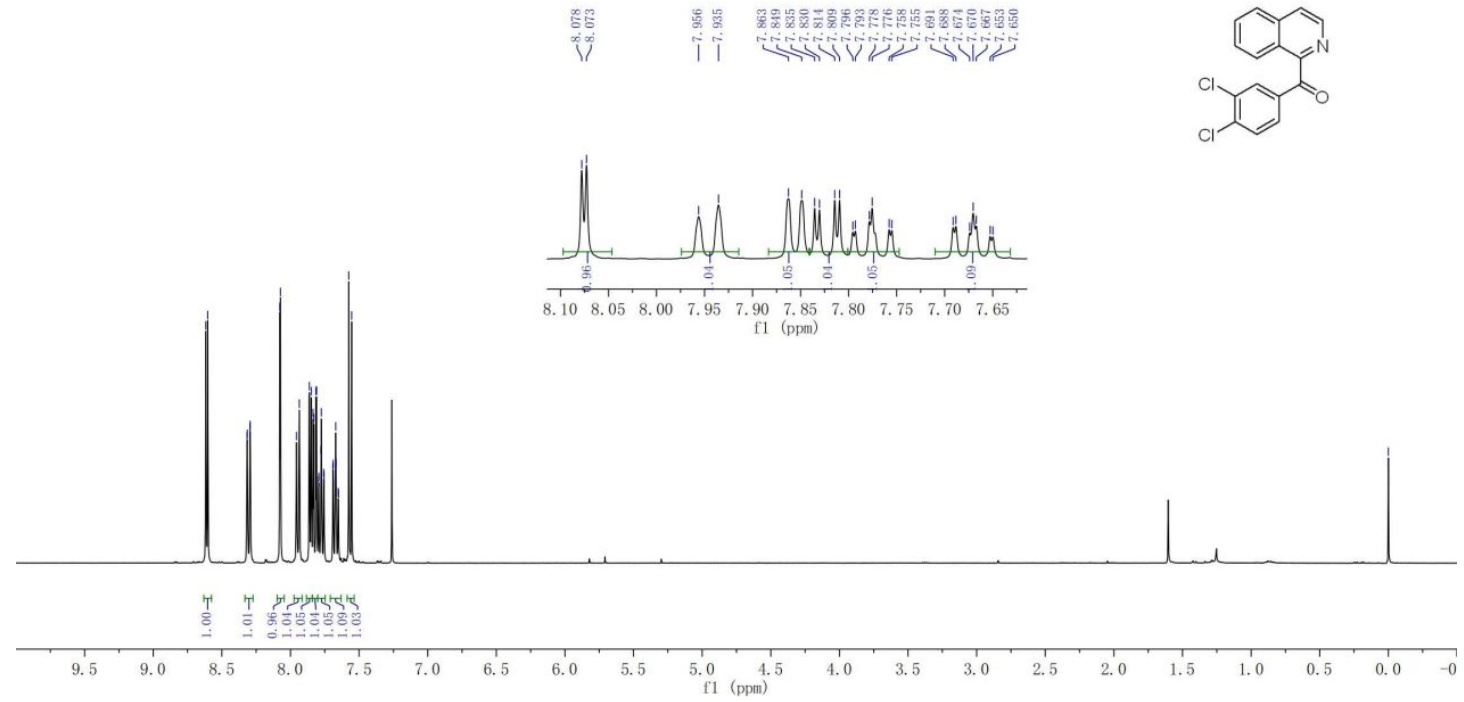

Figure S42. ${ }^{1} \mathrm{H}$ NMR Spectra of $\mathbf{3 m}$

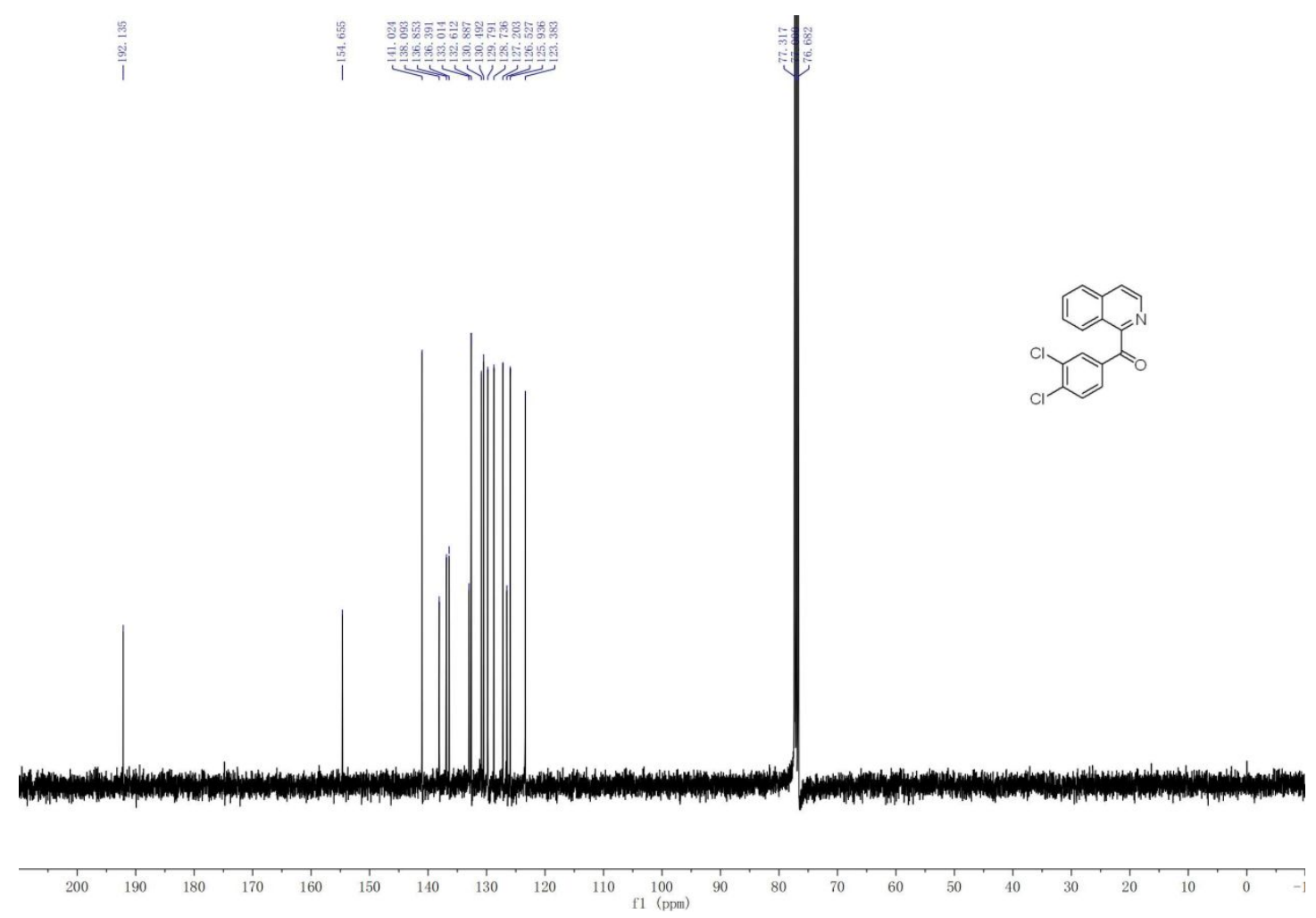

Figure S43. ${ }^{13} \mathrm{C}$ NMR Spectra of $\mathbf{3 m}$ 
isoquinolin-1-yl(naphthalen-2-yl)methanone (3n)

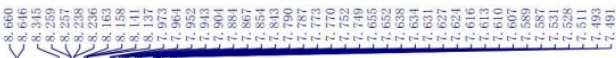
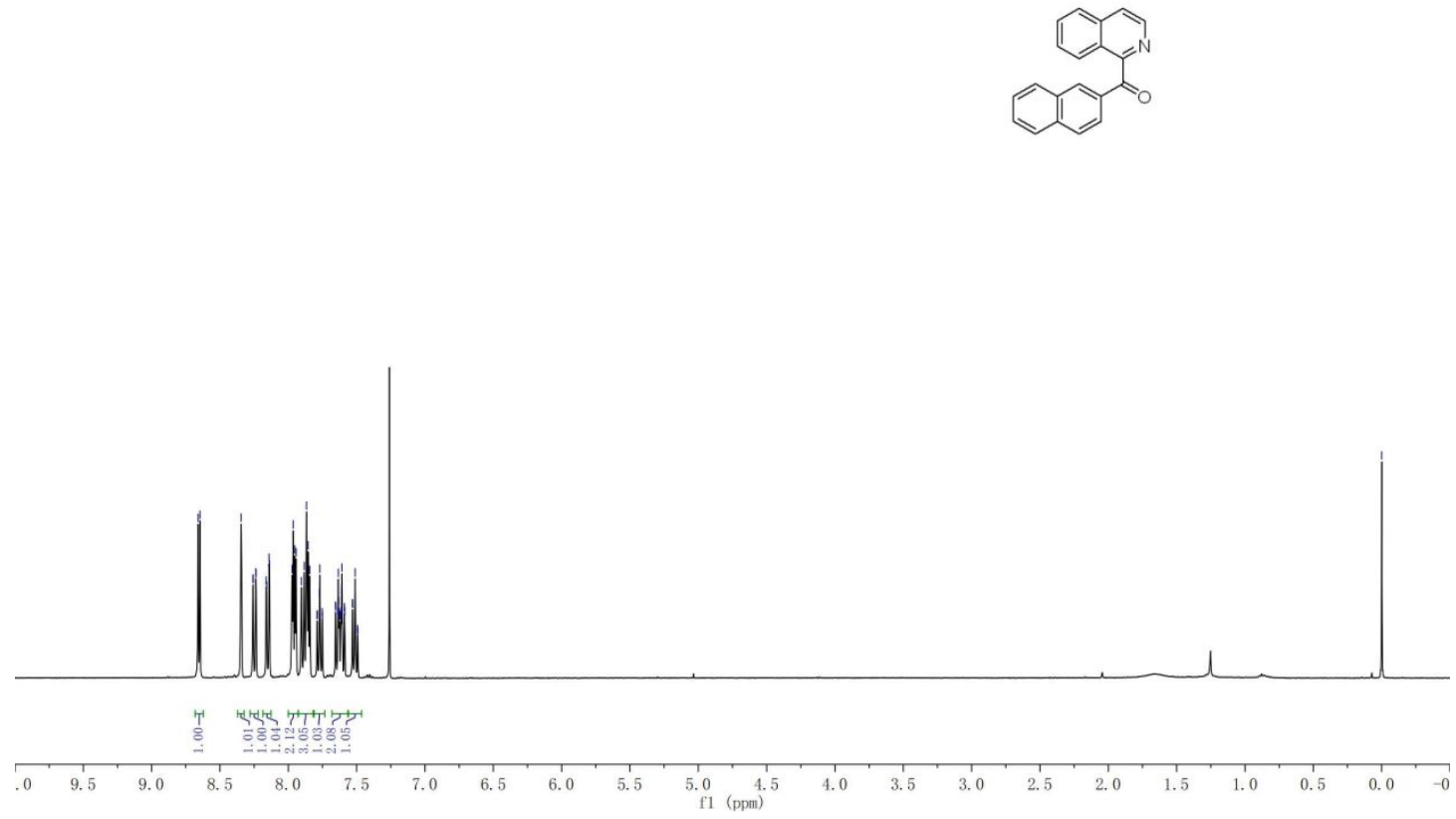

Figure S44. ${ }^{1} \mathrm{H}$ NMR Spectra of $\mathbf{3 n}$

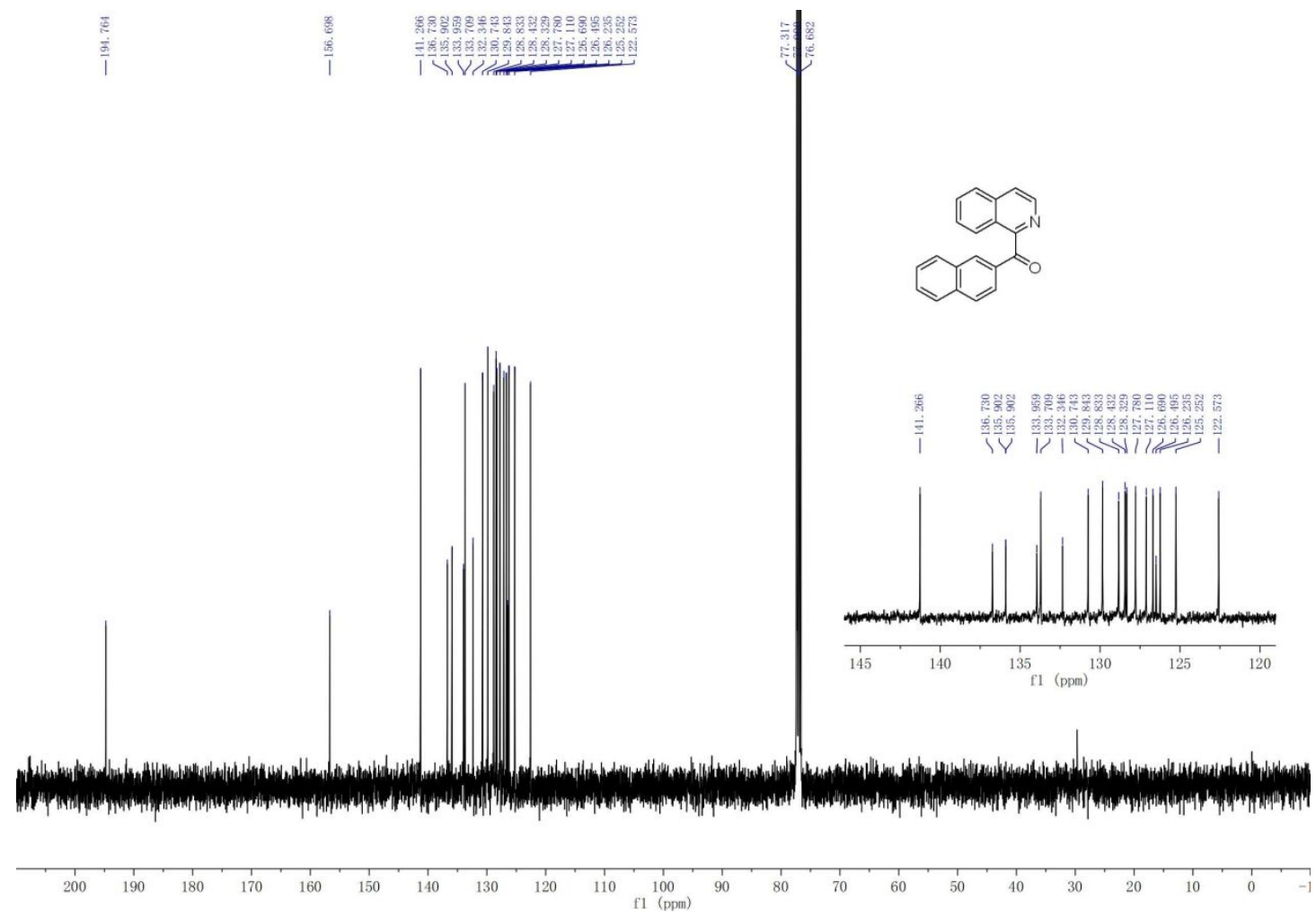

Figure S45. ${ }^{13} \mathrm{C}$ NMR Spectra of $\mathbf{3 n}$ 
isoquinolin-1-yl(thiophen-2-yl)methanone (3o)

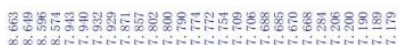

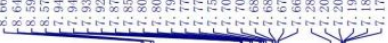
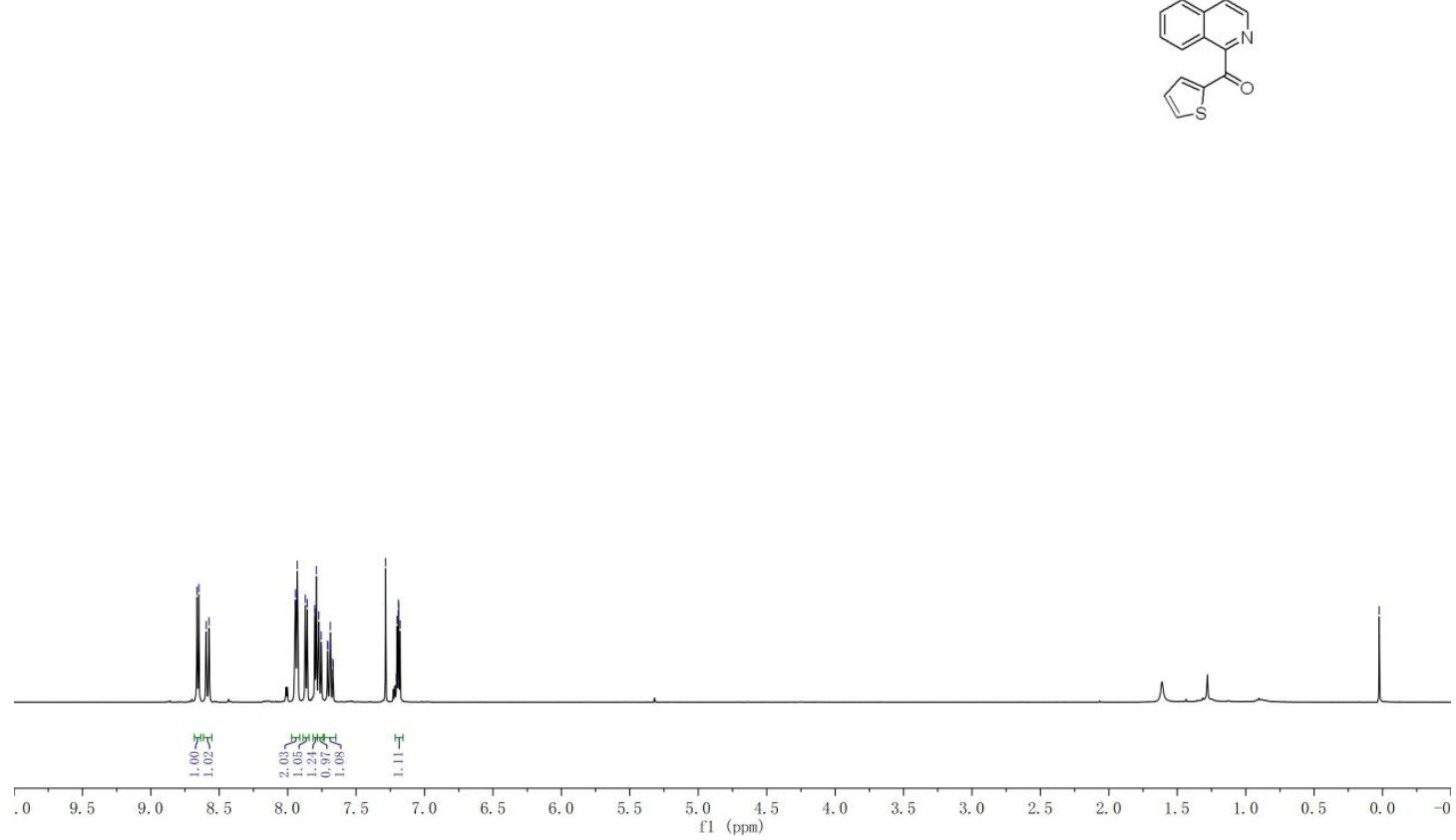

Figure S46. ${ }^{1} \mathrm{H}$ NMR Spectra of $\mathbf{3 o}$

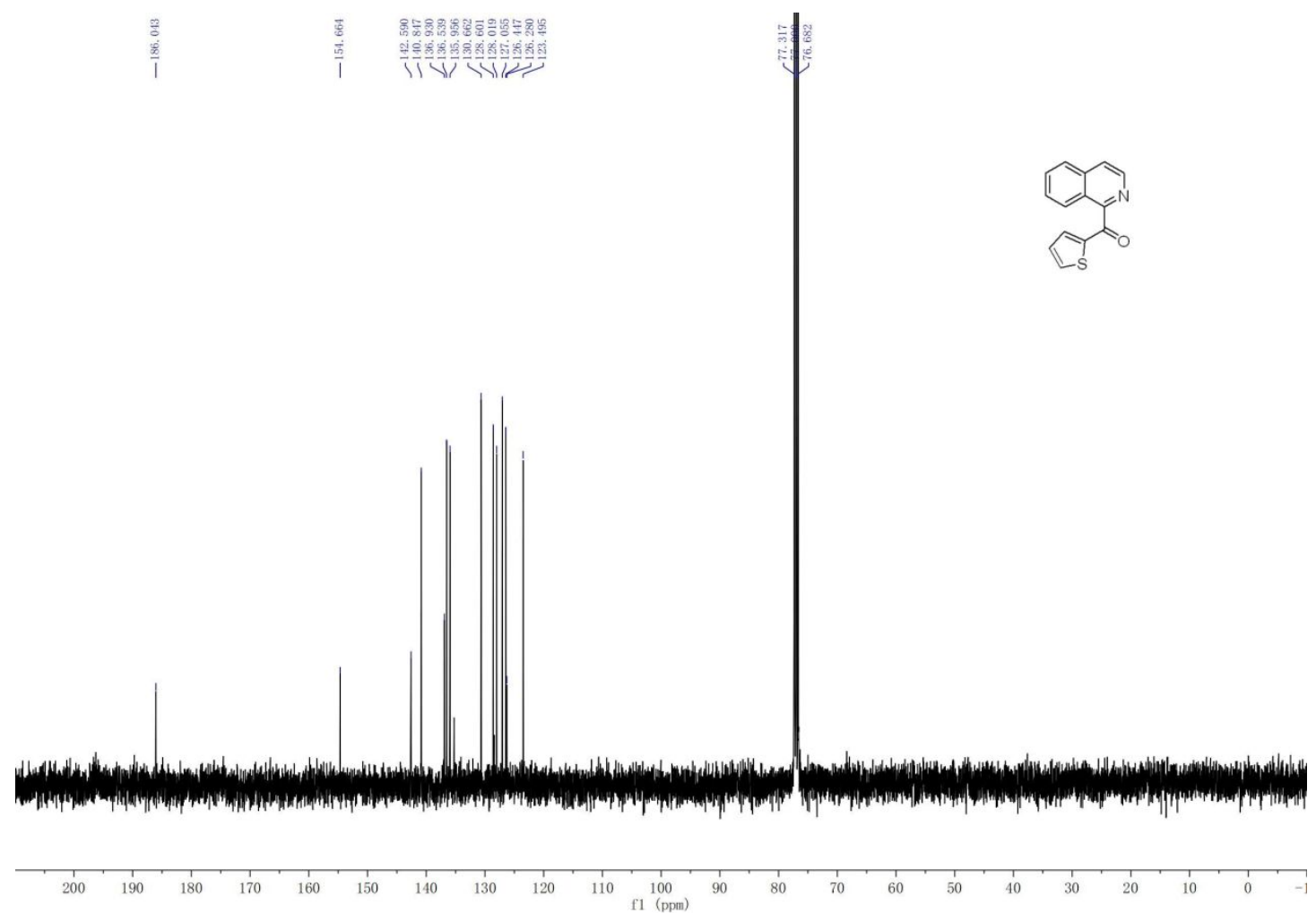

Figure S47. ${ }^{13} \mathrm{C}$ NMR Spectra of $3 \mathrm{o}$ 
(5-bromoisoquinolin-1-yl)(phenyl)methanone (3p)

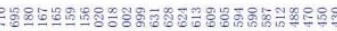

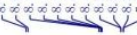
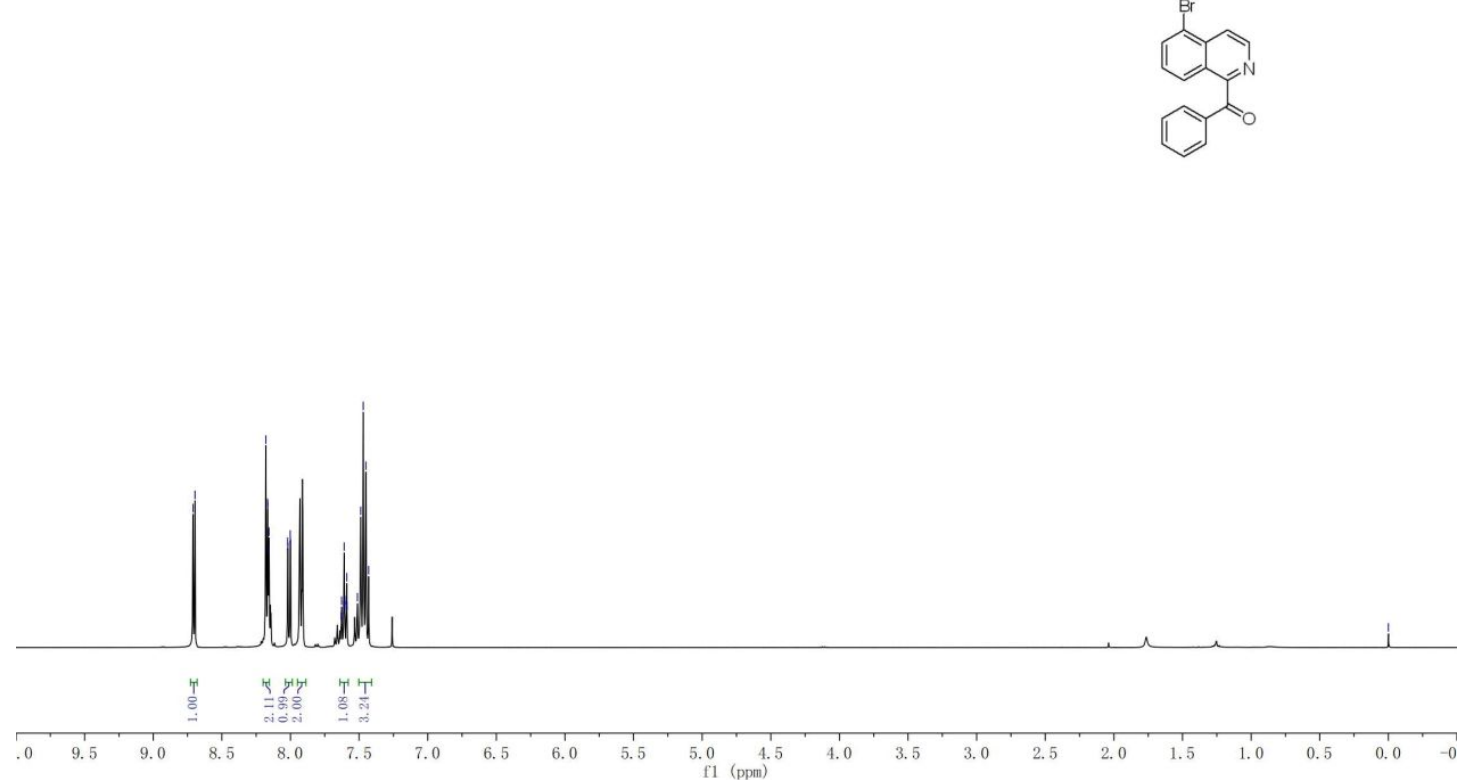

Figure S48. ${ }^{1} \mathrm{H}$ NMR Spectra of $\mathbf{3 p}$

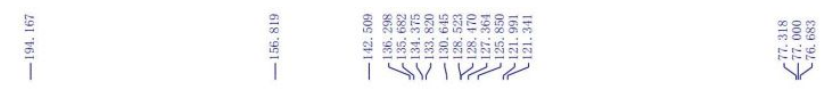
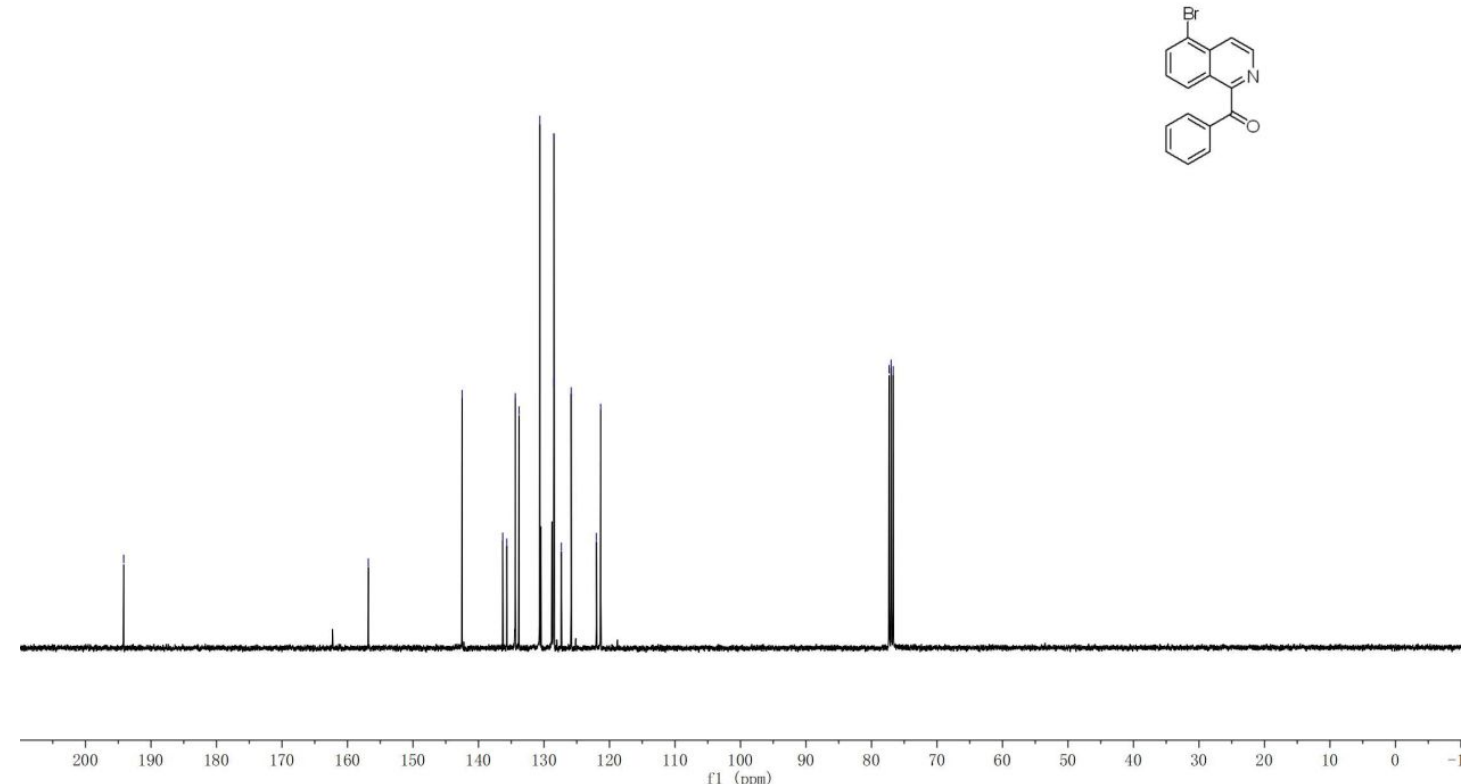

Figure S49. ${ }^{13} \mathrm{C}$ NMR Spectra of $\mathbf{3 p}$ 
(4-bromoisoquinolin-1-yl)(phenyl)methanone (3q)

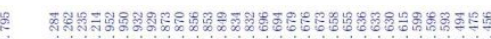

i.

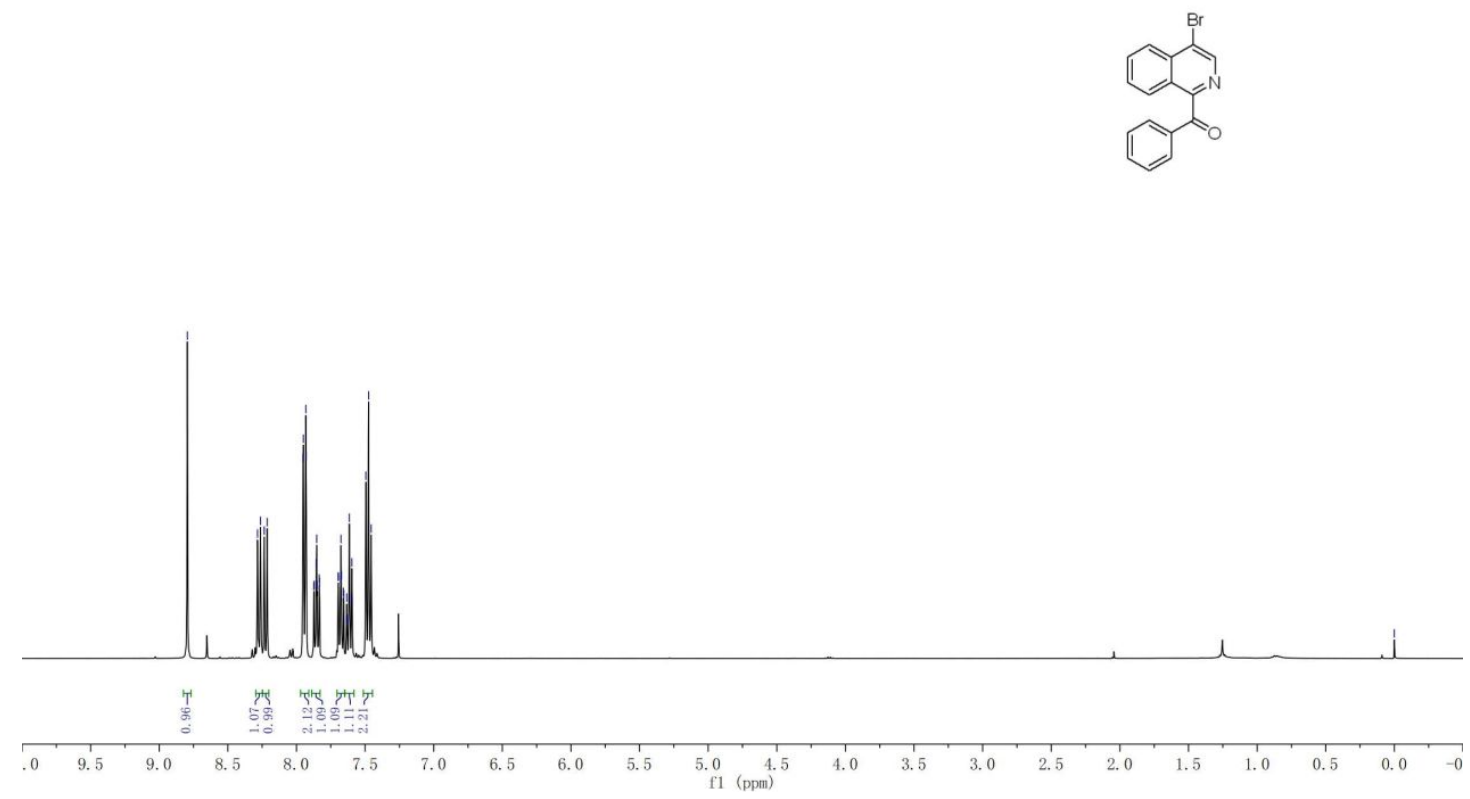

Figure S50. ${ }^{1} \mathrm{H}$ NMR Spectra of $\mathbf{3 q}$
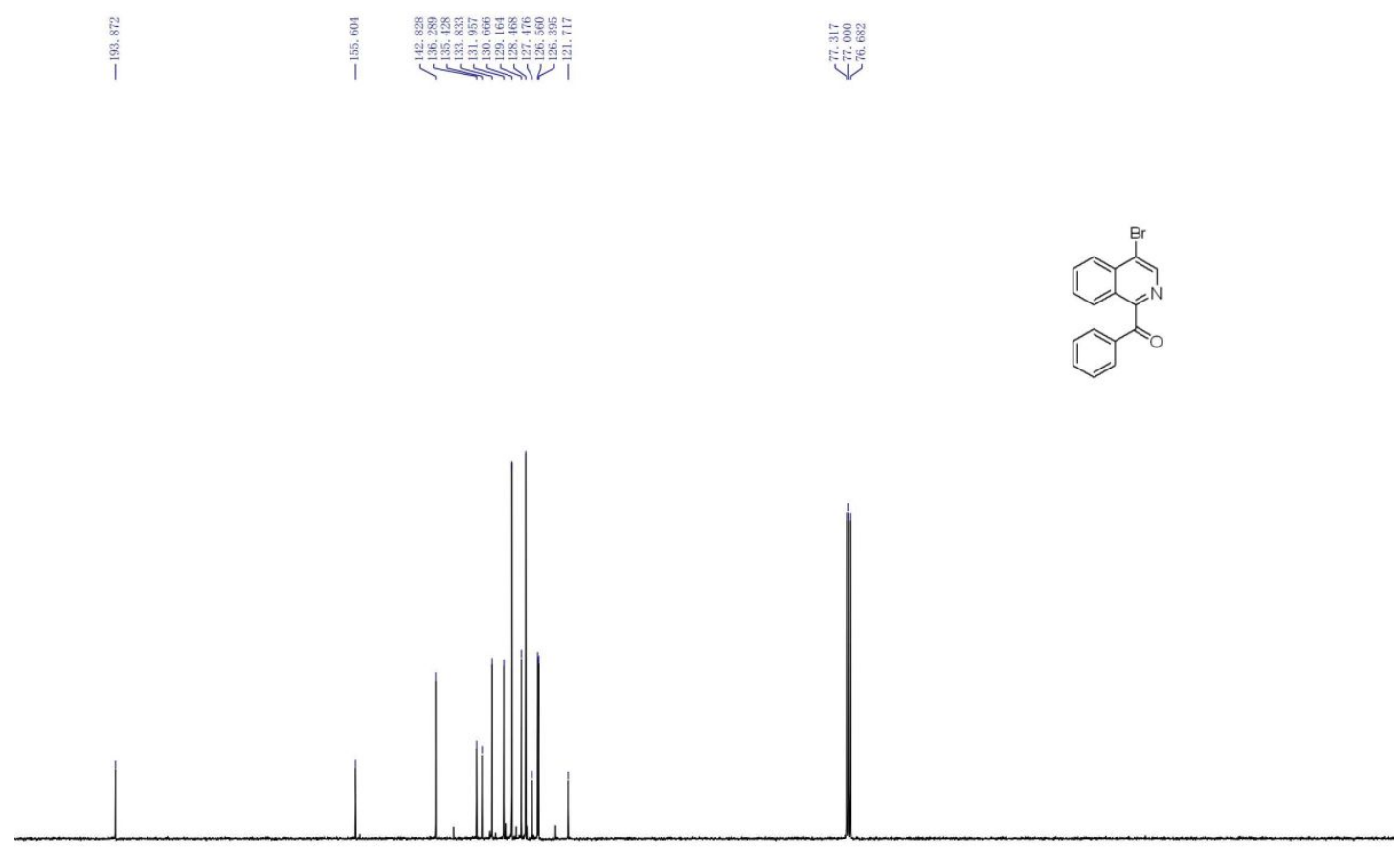

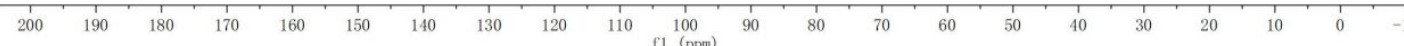

Figure S51. ${ }^{13} \mathrm{C}$ NMR Spectra of 3q 
(6-methylisoquinolin-1-yl)(phenyl)methanone (3r)

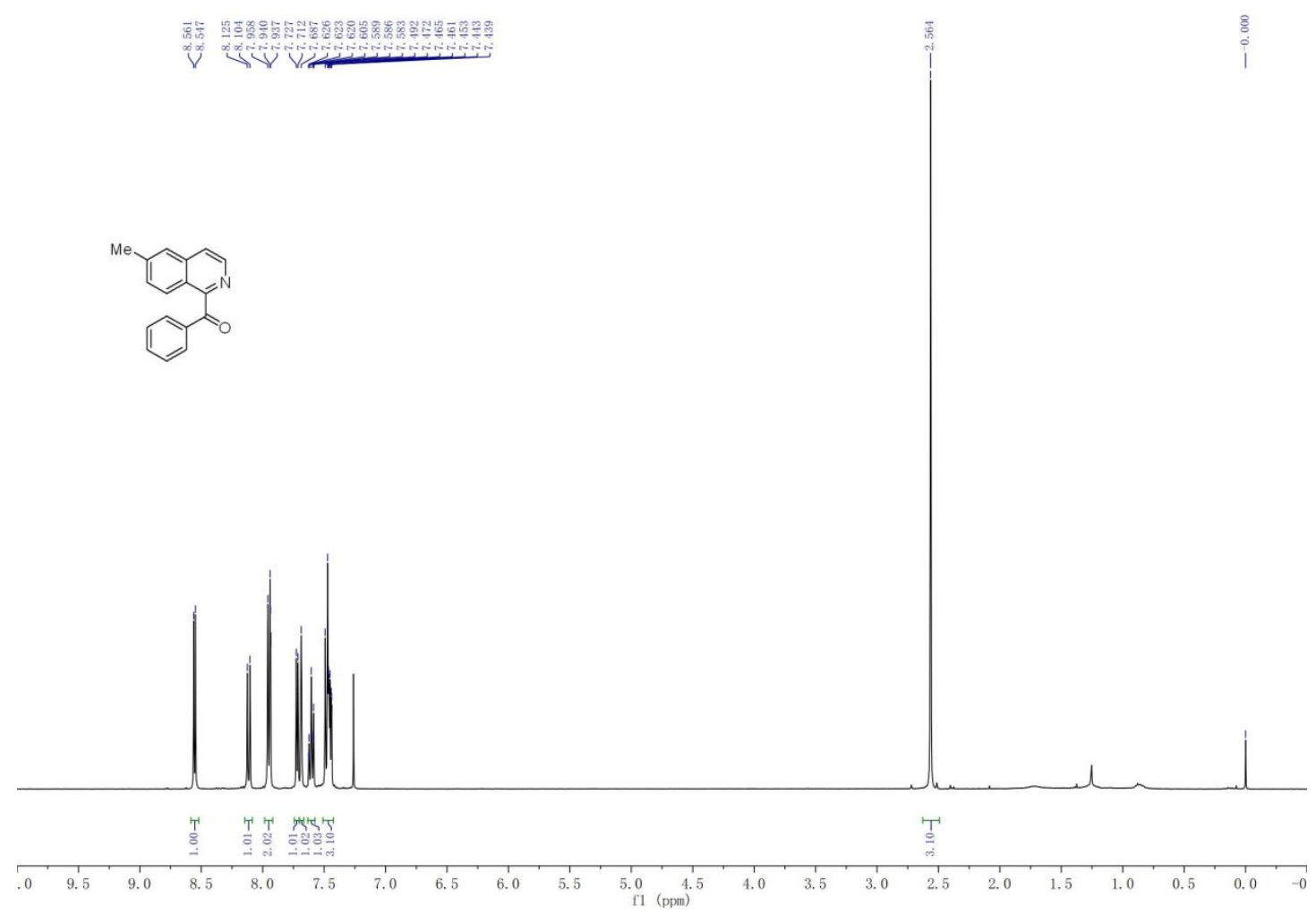

Figure S52. ${ }^{1} \mathrm{H}$ NMR Spectra of $\mathbf{3 r}$

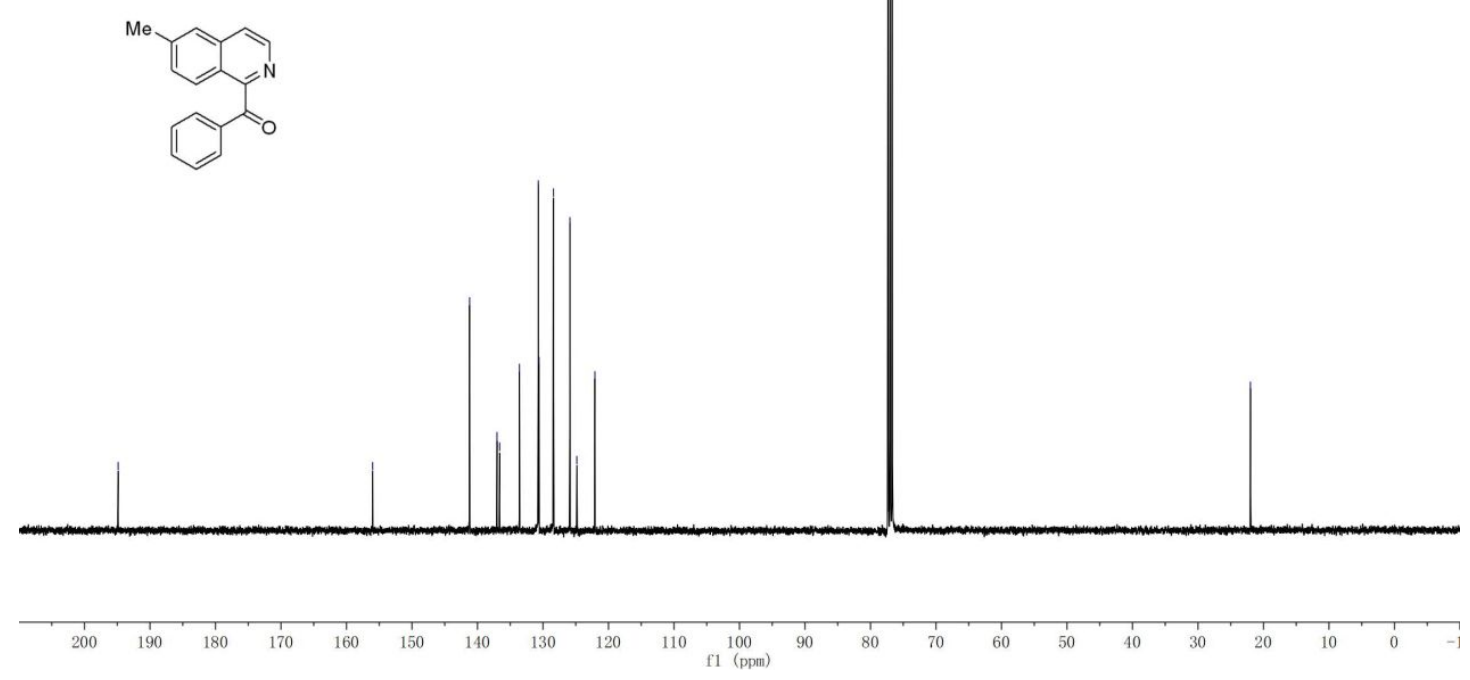

Figure S53. ${ }^{13} \mathrm{C}$ NMR Spectra of $\mathbf{3 r}$ 
phenyl(quinoxalin-2-yl)methanone (3s)

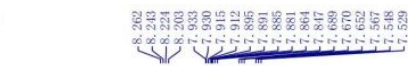
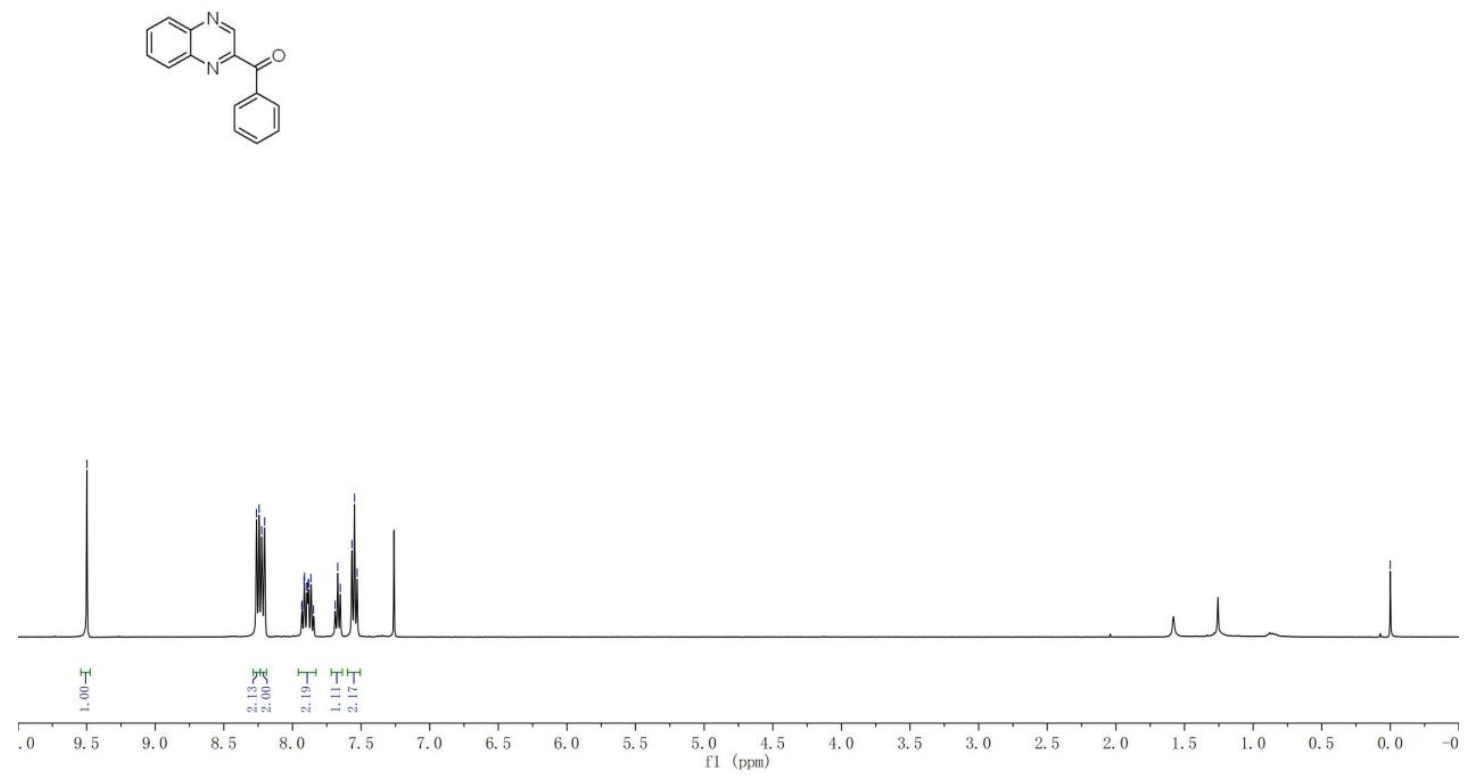

Figure S54. ${ }^{1} \mathrm{H}$ NMR Spectra of 3s

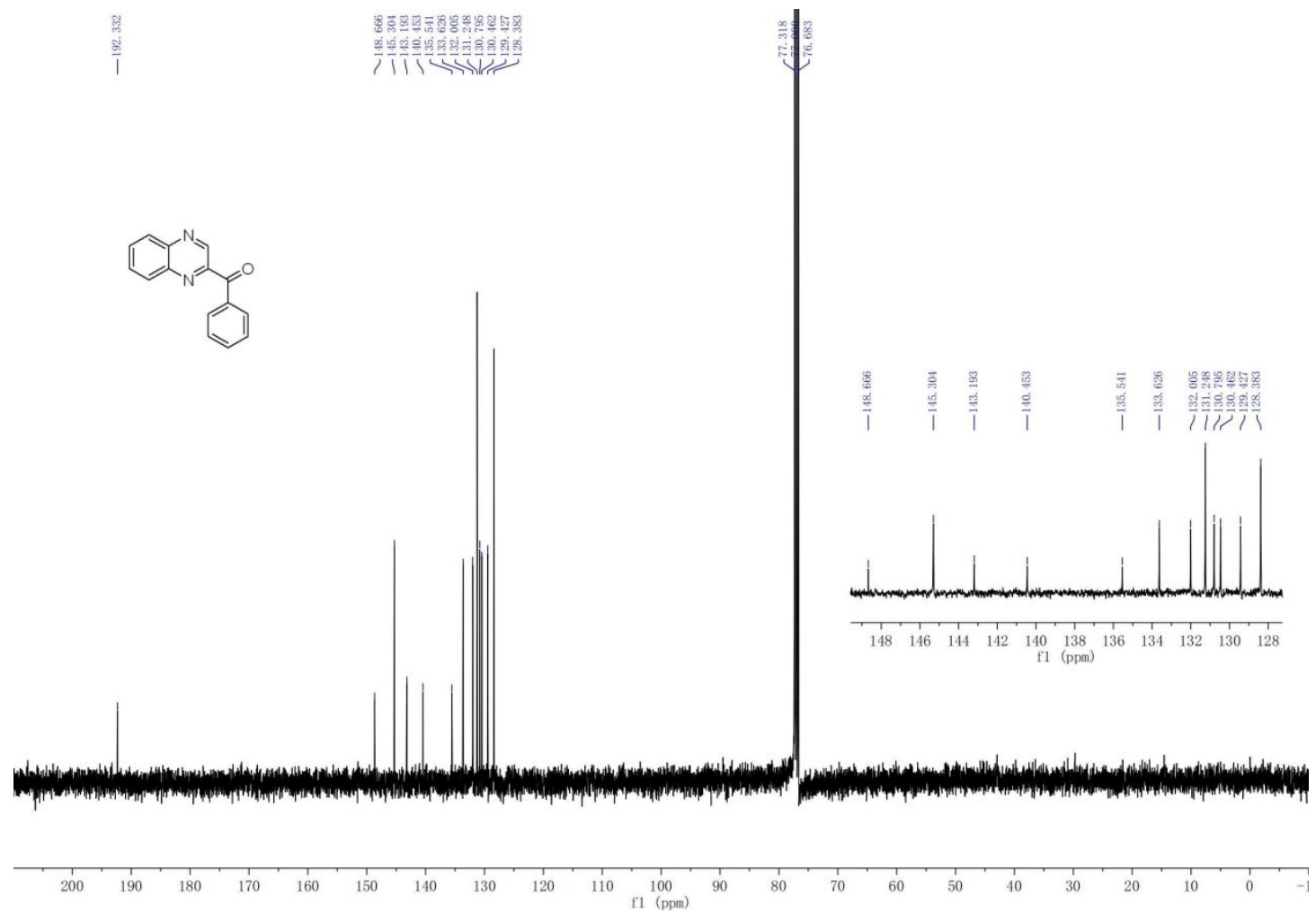

Figure S55. ${ }^{13} \mathrm{C}$ NMR Spectra of $\mathbf{3 s}$ 
quinoxaline-2,3-diylbis(phenylmethanone) (3s')

\section{$\left(3 s^{\prime}\right)$}

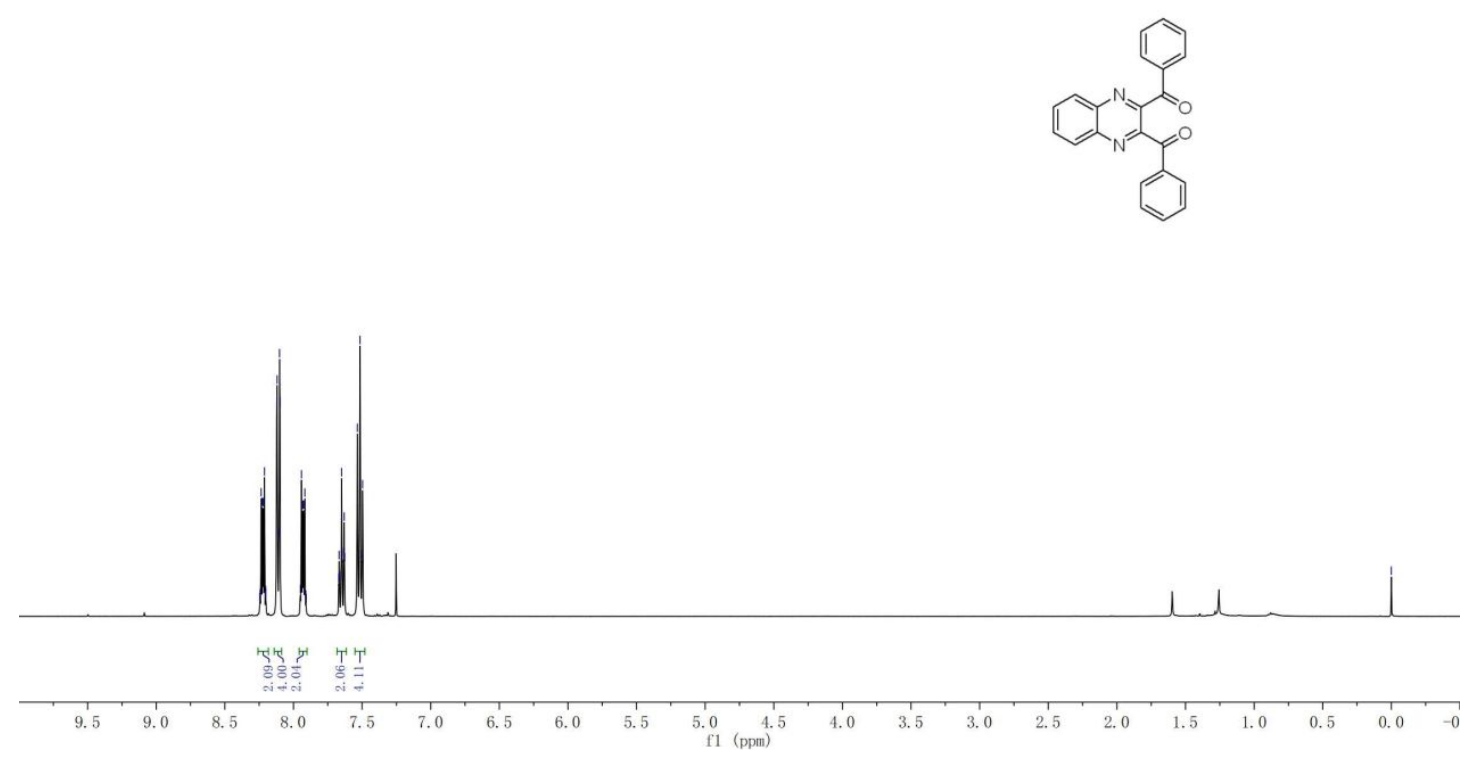

Figure S56. ${ }^{1} \mathrm{H}$ NMR Spectra of 3s'

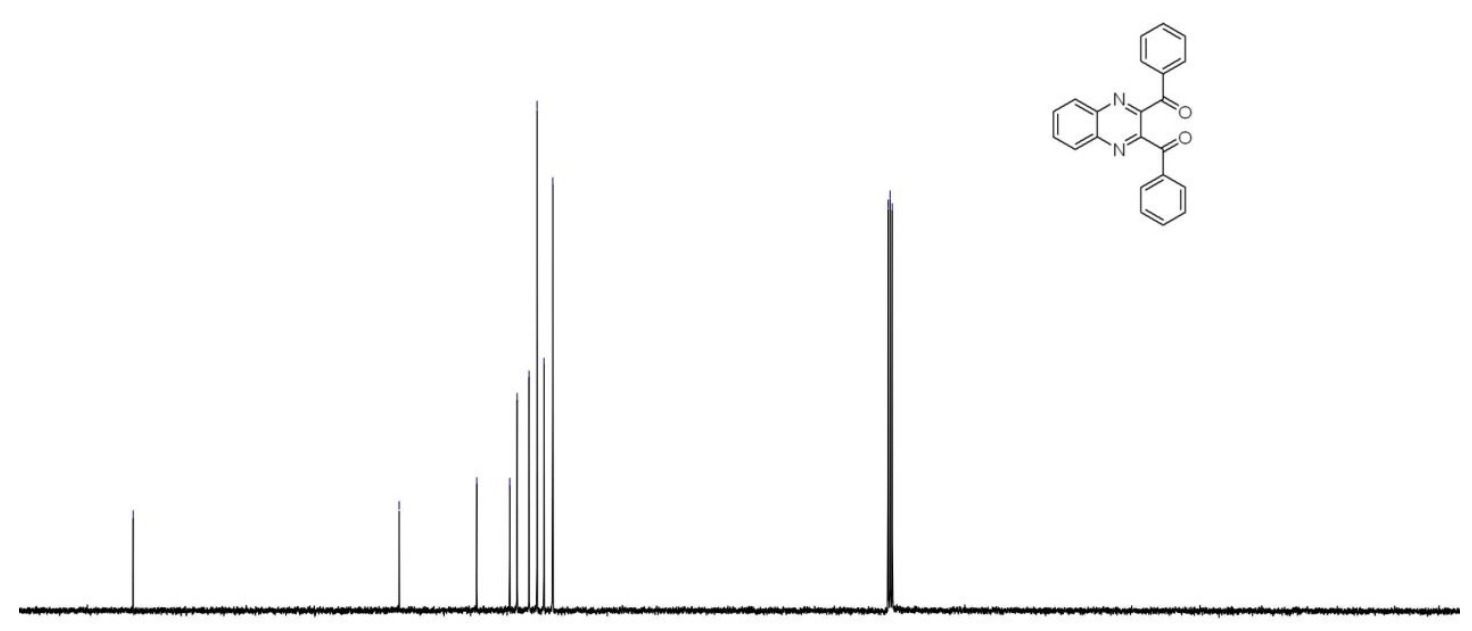

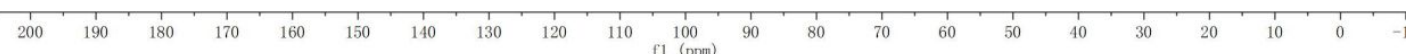

Figure S57. ${ }^{13} \mathrm{C}$ NMR Spectra of 3s' 
(3-methylquinoxalin-2-yl)(phenyl)methanone (3t)

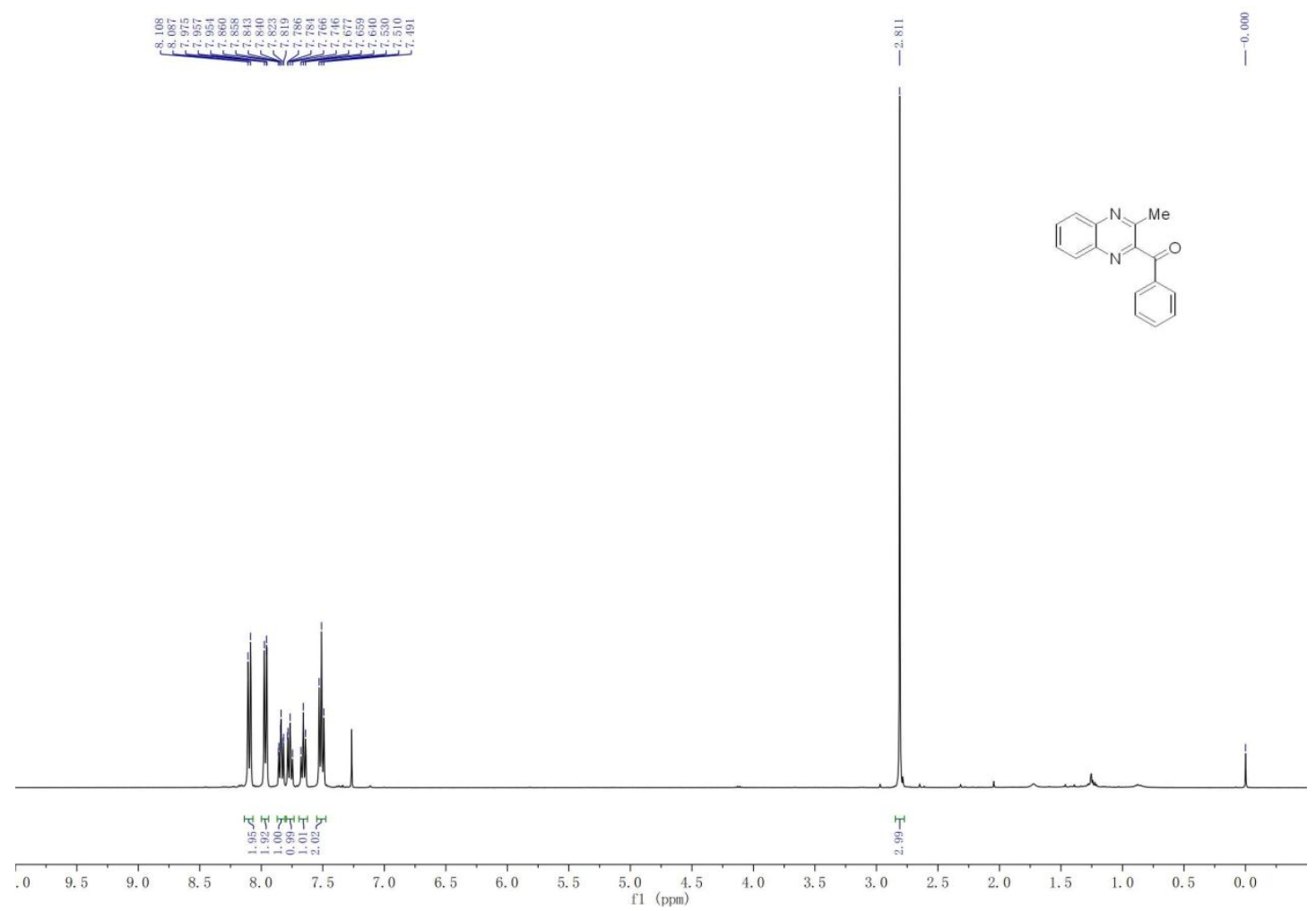

Figure S58. ${ }^{1} \mathrm{H}$ NMR Spectra of $\mathbf{3 t}$

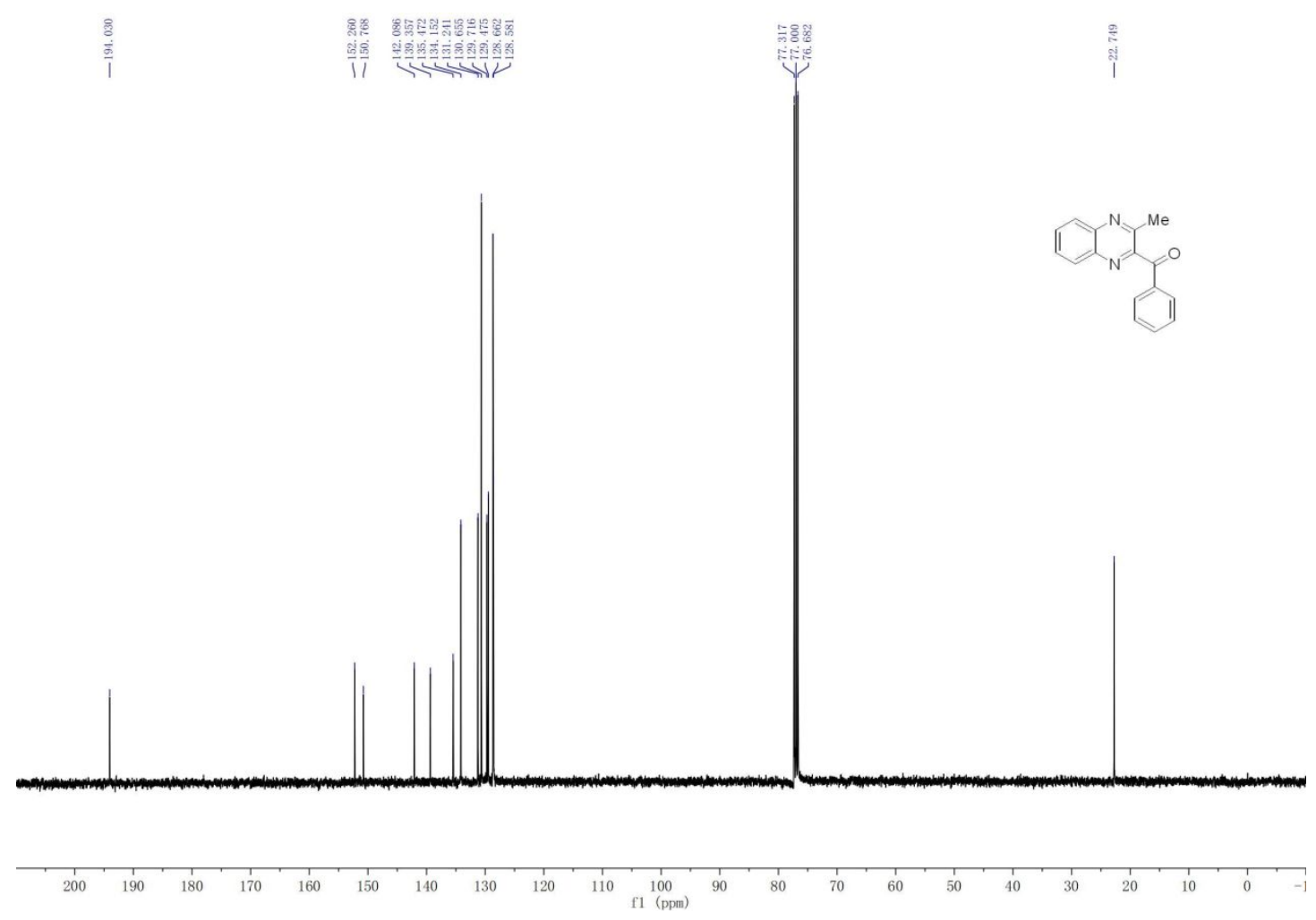

Figure S59. ${ }^{13} \mathrm{C}$ NMR Spectra of $\mathbf{3 t}$ 


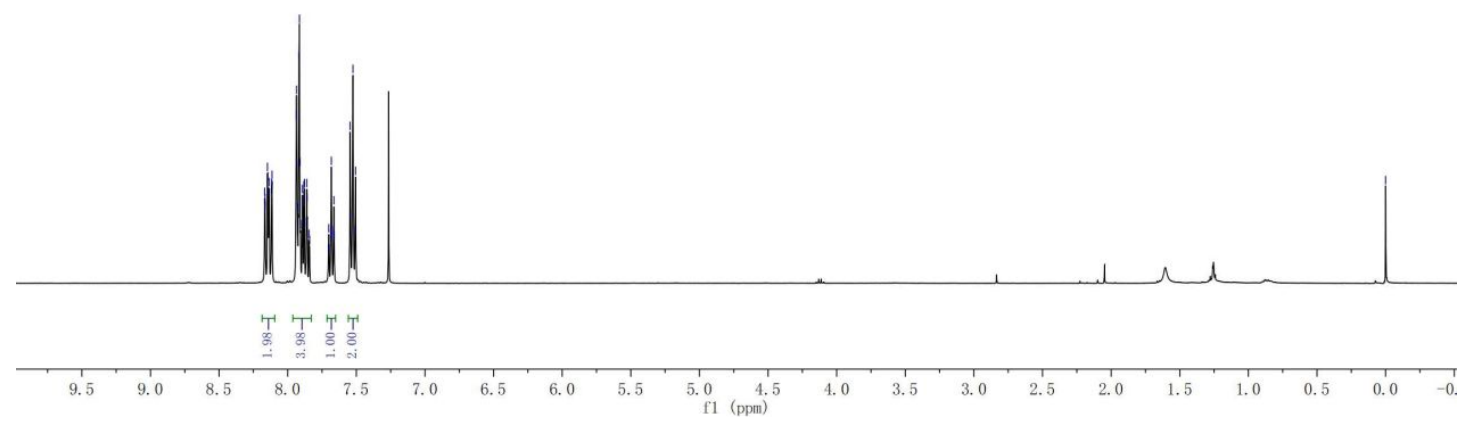

Figure S60. ${ }^{1} \mathrm{H}$ NMR Spectra of $\mathbf{3 u}$

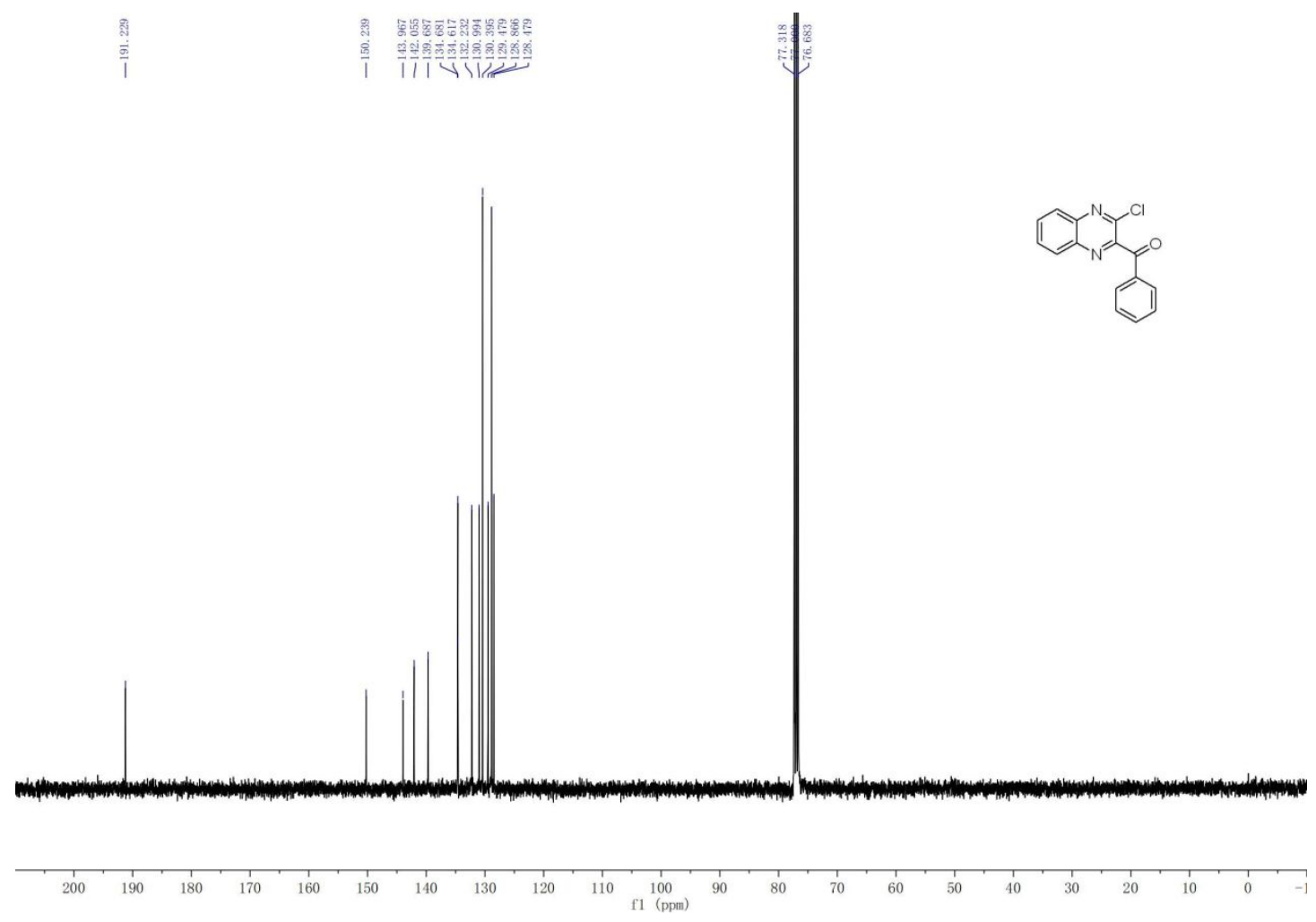

Figure S61. ${ }^{13} \mathrm{C}$ NMR Spectra of $\mathbf{3 t}$ 
phenyl(quinazolin-4-yl)methanone (3v)

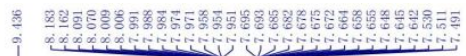

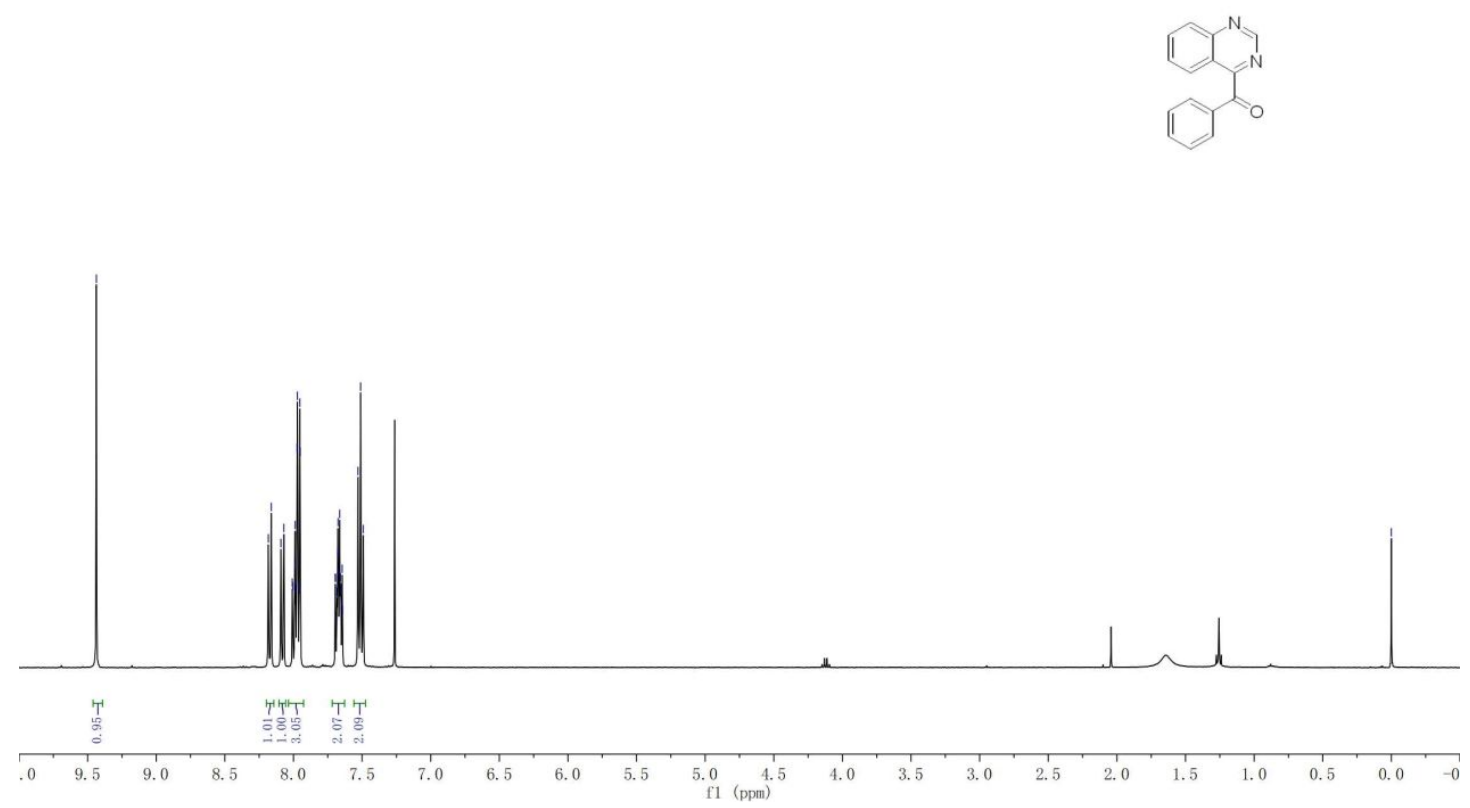

Figure S62. ${ }^{1} \mathrm{H}$ NMR Spectra of $\mathbf{3 v}$

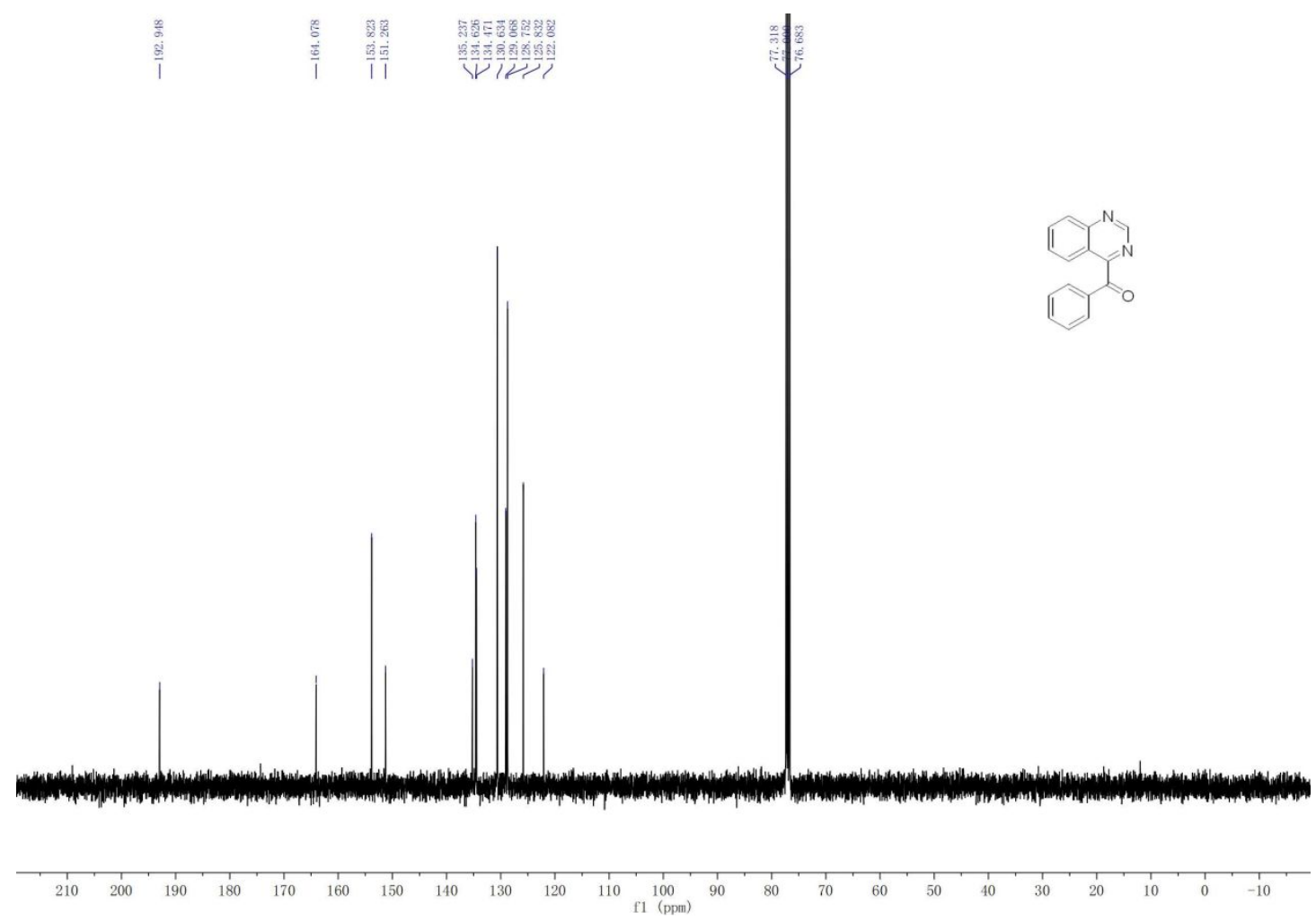

Figure S63. ${ }^{13} \mathrm{C}$ NMR Spectra of $\mathbf{3 v}$ 
acridin-9-yl(phenyl)methanone (3w)

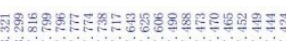

i)
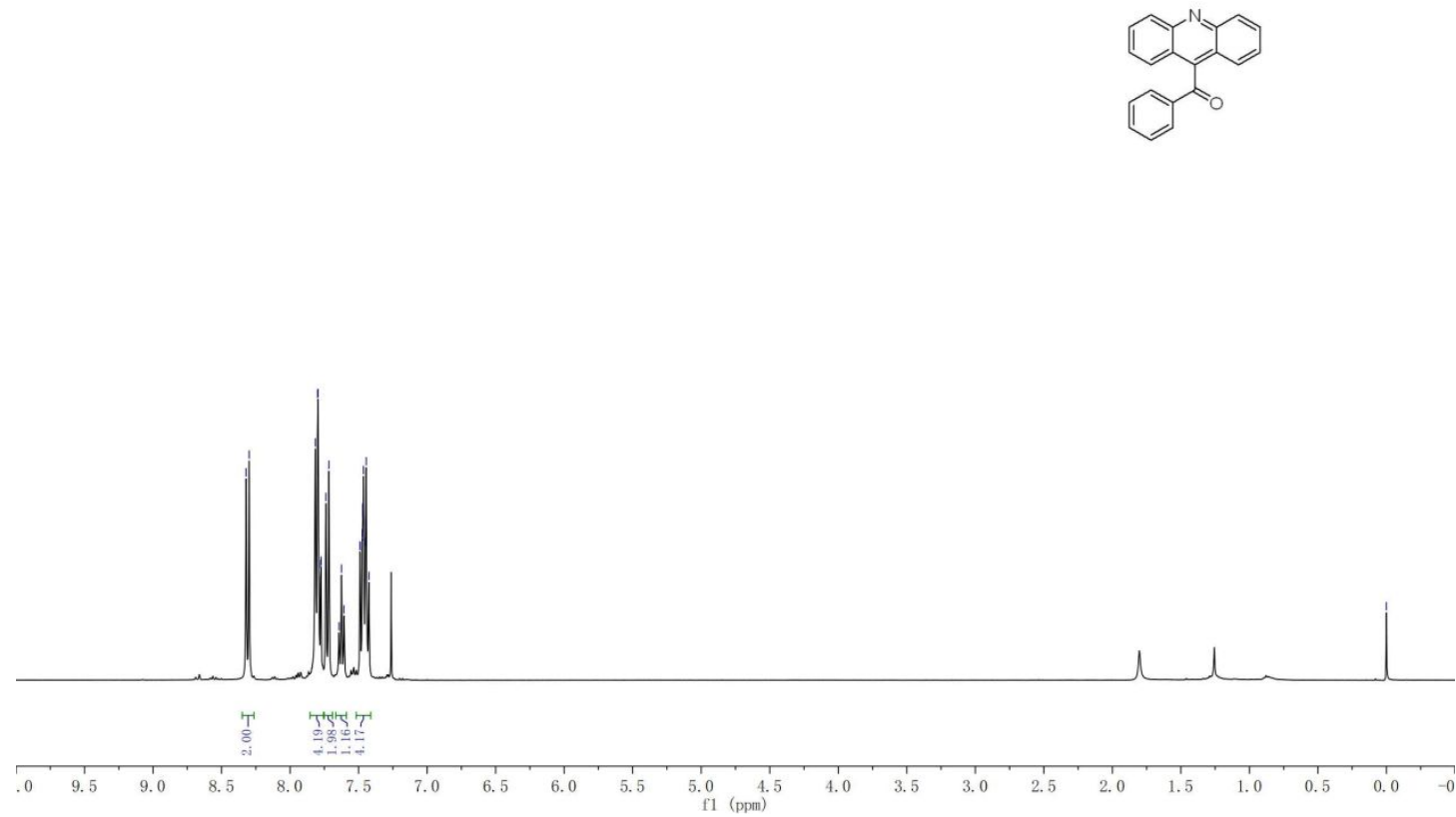

Figure S64. ${ }^{1} \mathrm{H}$ NMR Spectra of $\mathbf{3 w}$

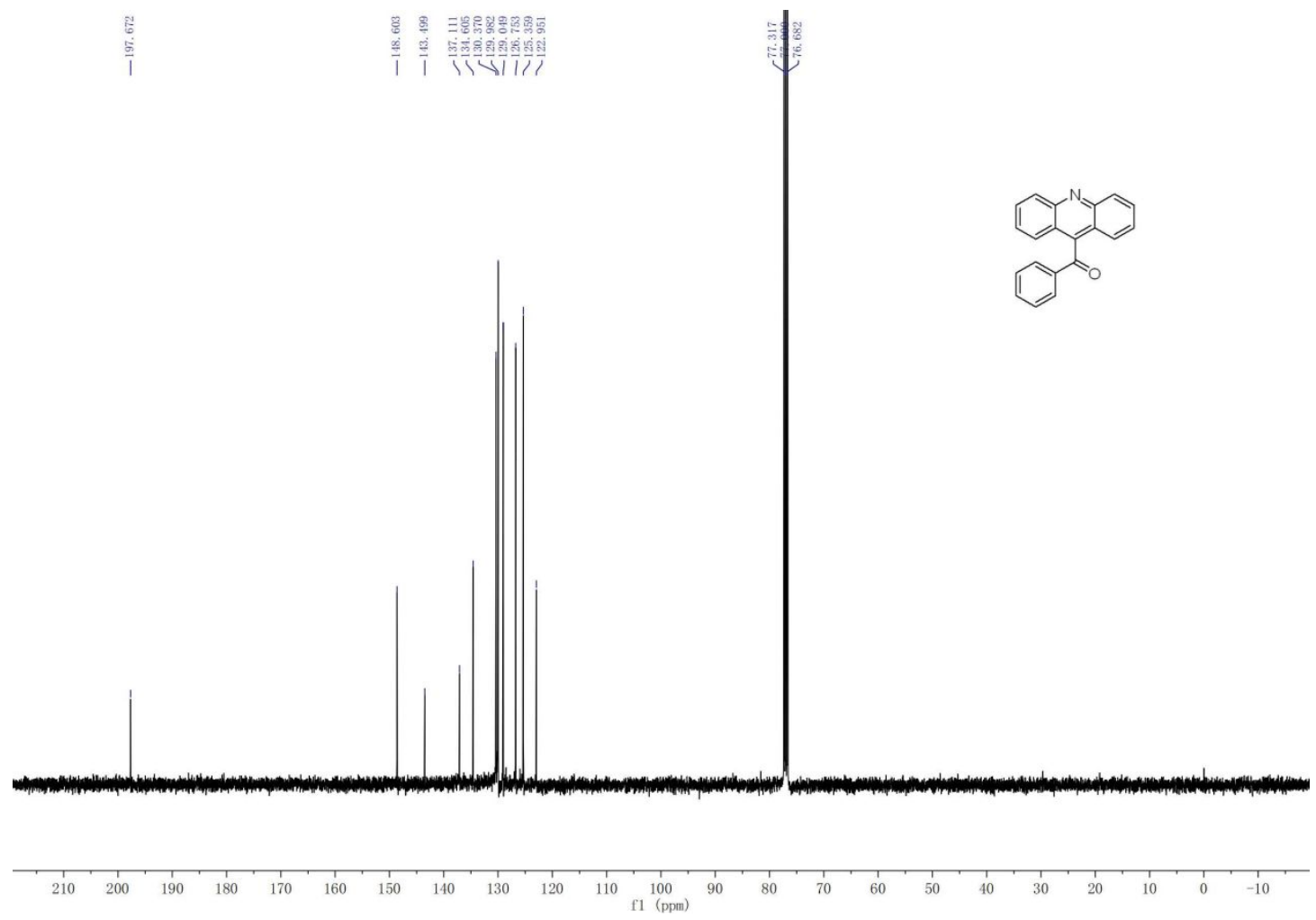

Figure S65. ${ }^{13} \mathrm{C}$ NMR Spectra of $\mathbf{3 w}$ 
2-benzoylisonicotinonitrile (3x)

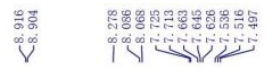
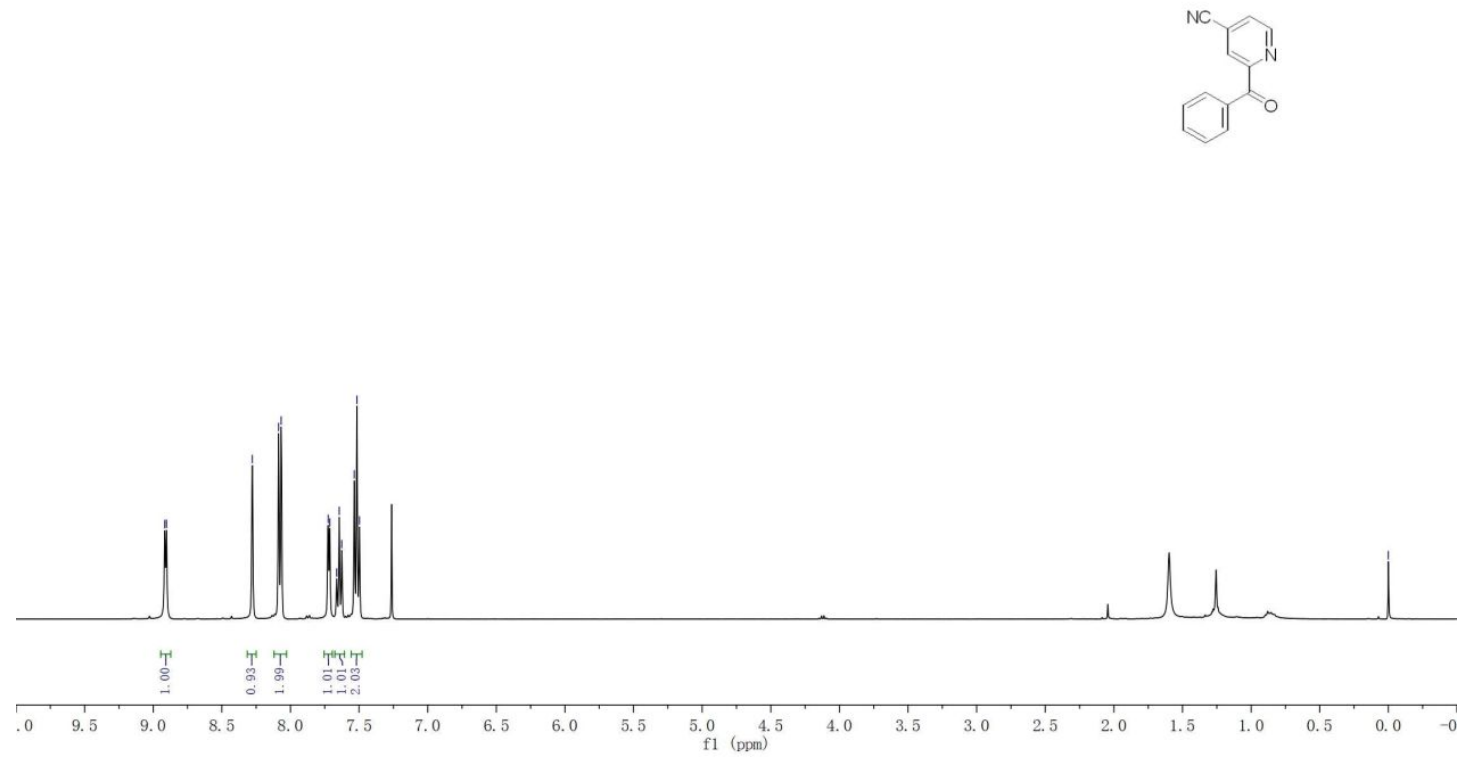

Figure S66. ${ }^{1} \mathrm{H}$ NMR Spectra of $\mathbf{3 x}$

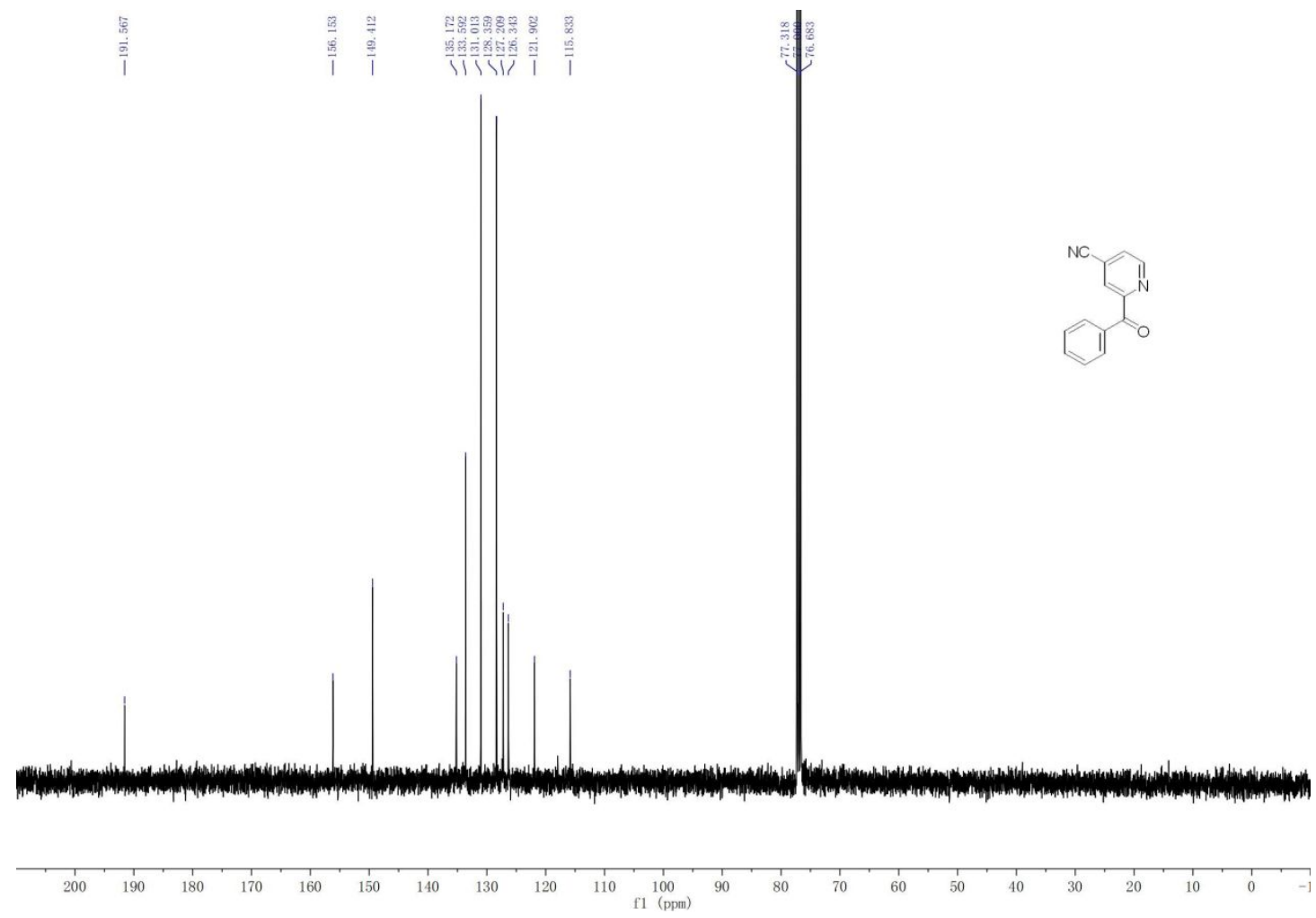

Figure S67. ${ }^{13} \mathrm{C}$ NMR Spectra of $\mathbf{3 x}$ 
benzo $[d]$ thiazol-2-yl(phenyl)methanone (3y)

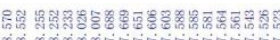

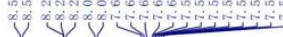
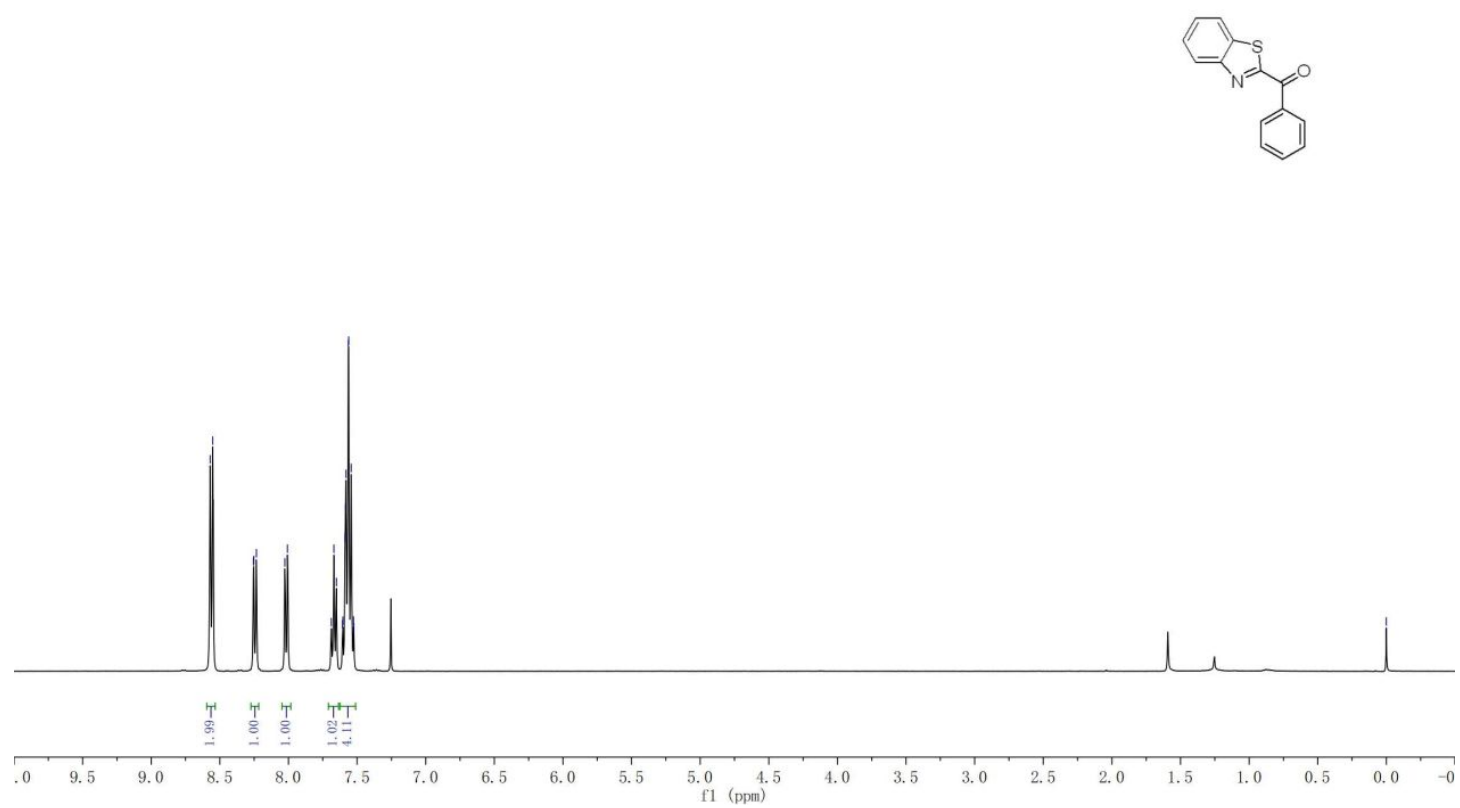

Figure S68. ${ }^{1} \mathrm{H}$ NMR Spectra of $\mathbf{3 y}$

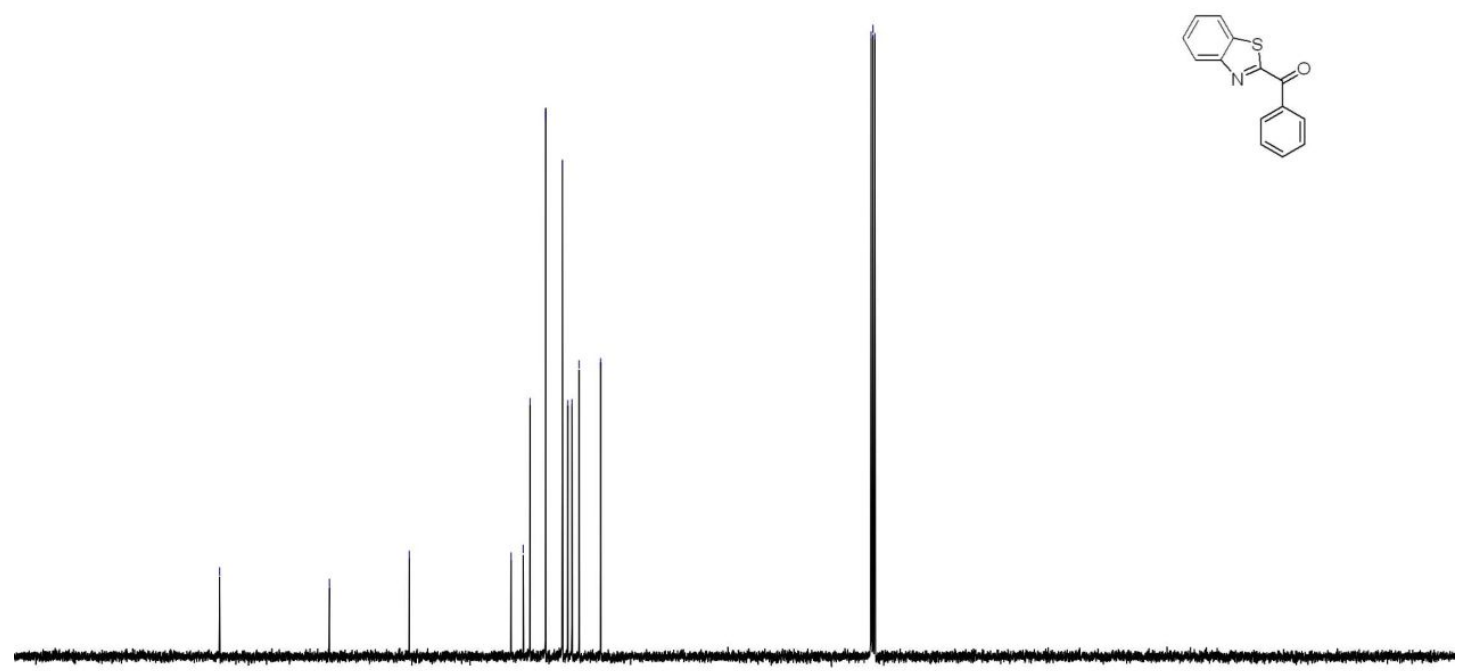

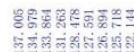

บ11

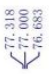

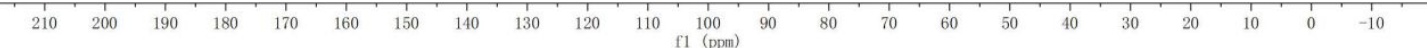

Figure S69. ${ }^{13} \mathrm{C}$ NMR Spectra of $\mathbf{3 y}$ 


\section{(2,3-diphenylpyrido[3,4-b]pyrazin-5-yl)(phenyl)methanone (3z)}

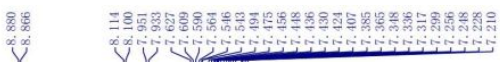

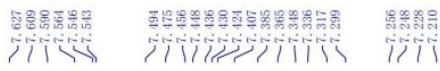
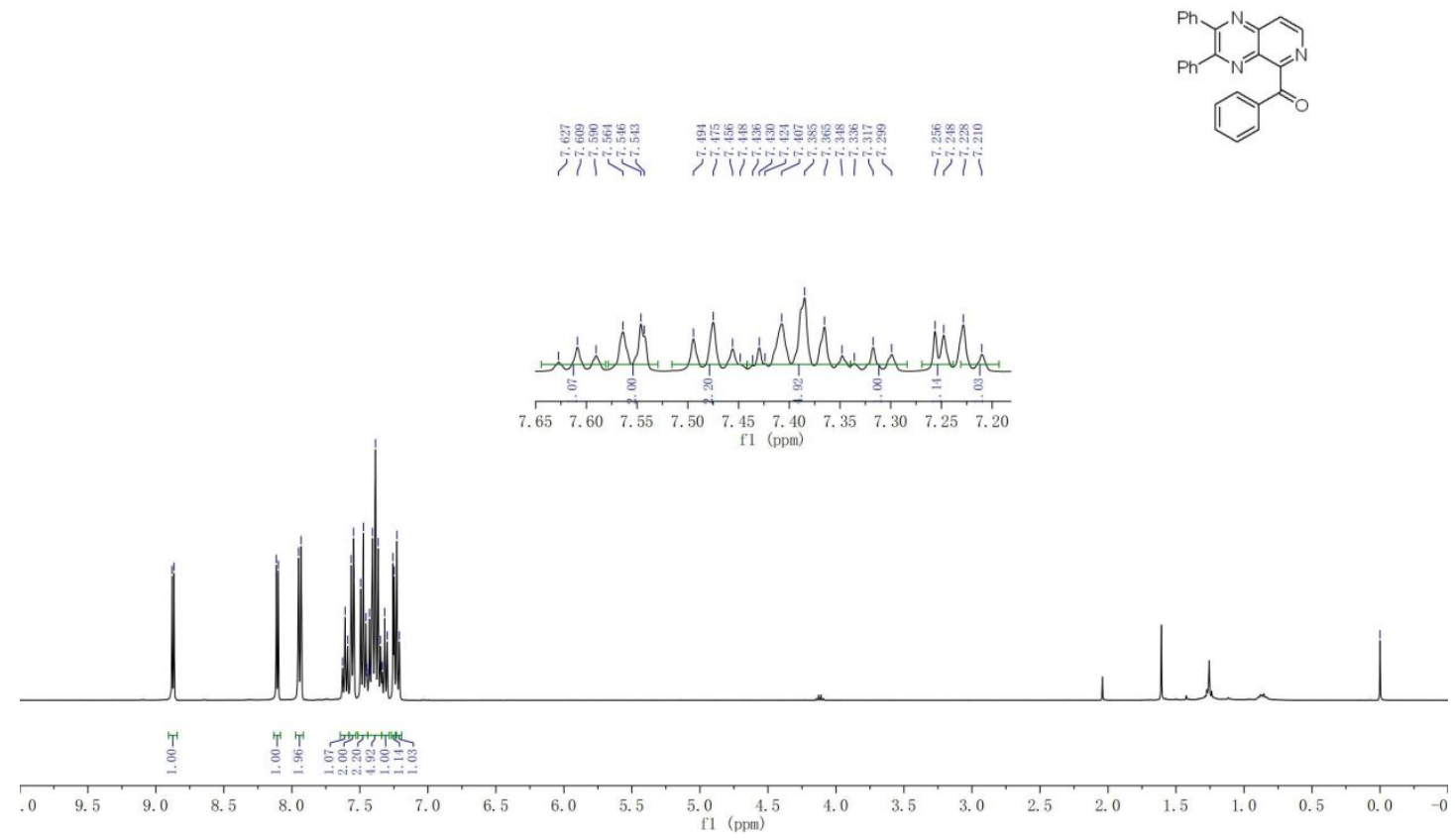

Figure S70. ${ }^{1} \mathrm{H}$ NMR Spectra of $\mathbf{3 z}$

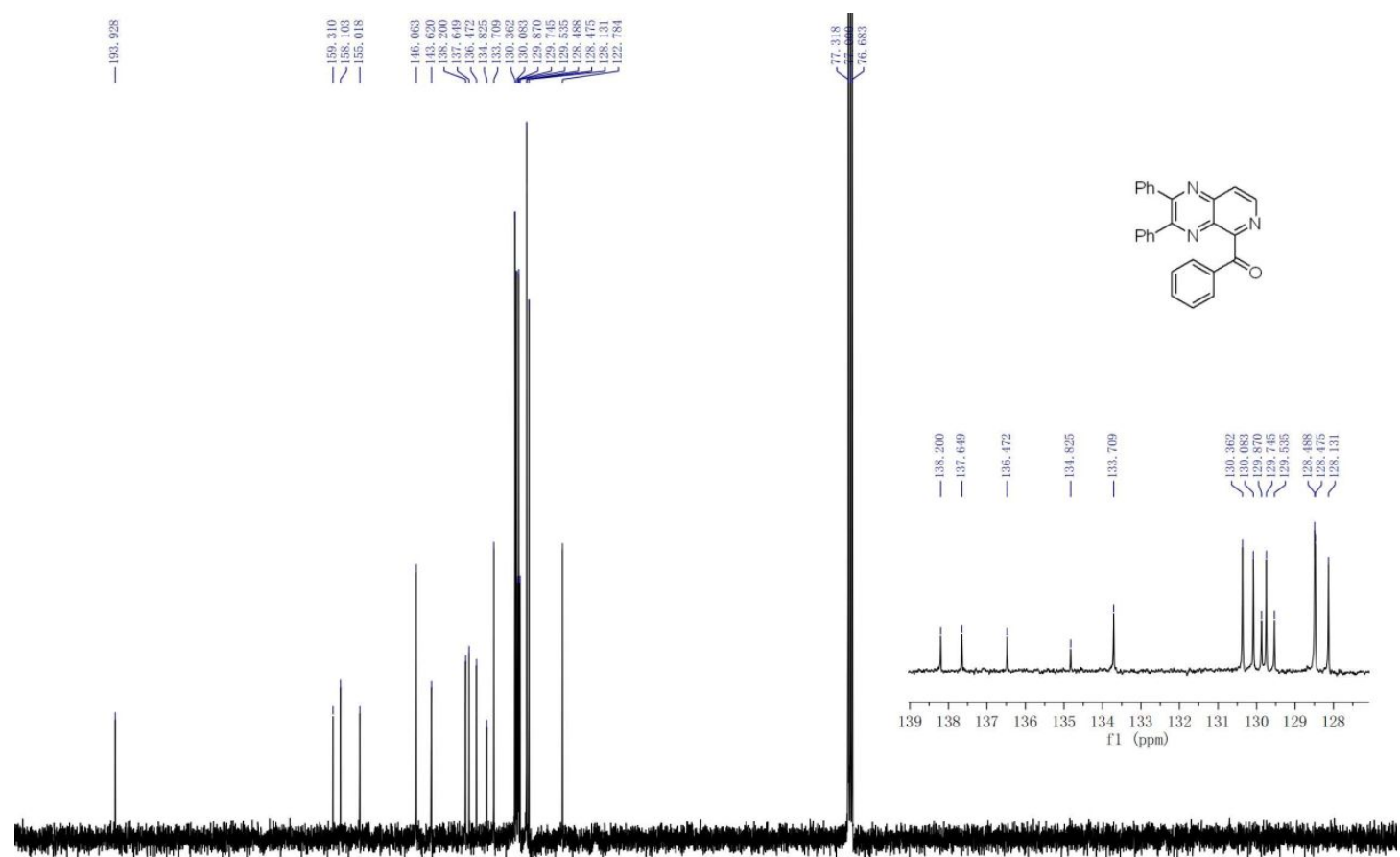

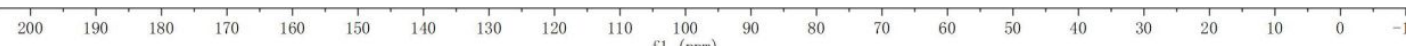

Figure S71. ${ }^{13} \mathrm{C}$ NMR Spectra of $\mathbf{3 z}$ 


\section{1-cyclohexylisoquinoline (6a)}

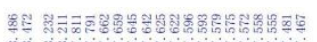

iv $y$

0

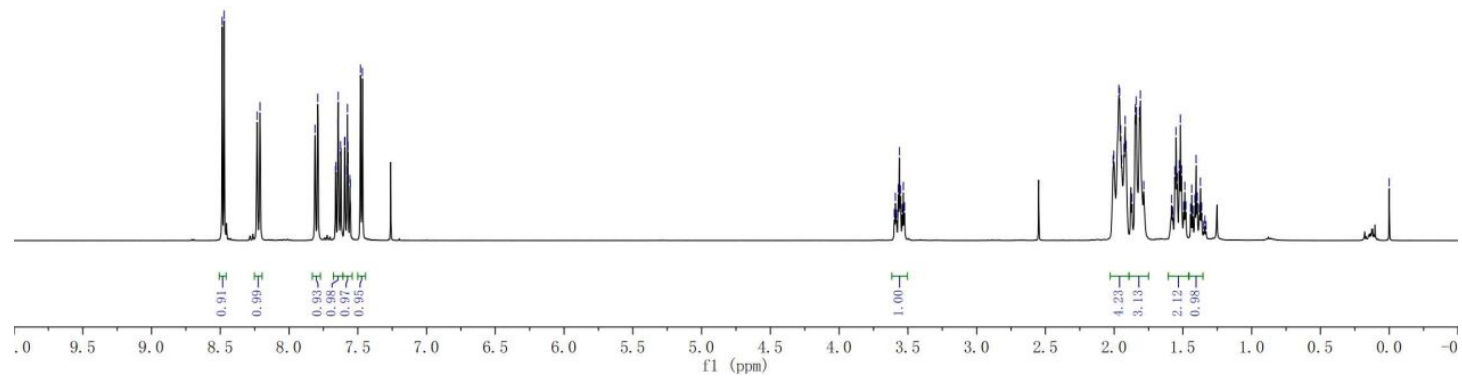

Figure S72. ${ }^{1} \mathrm{H}$ NMR Spectra of $\mathbf{6 a}$
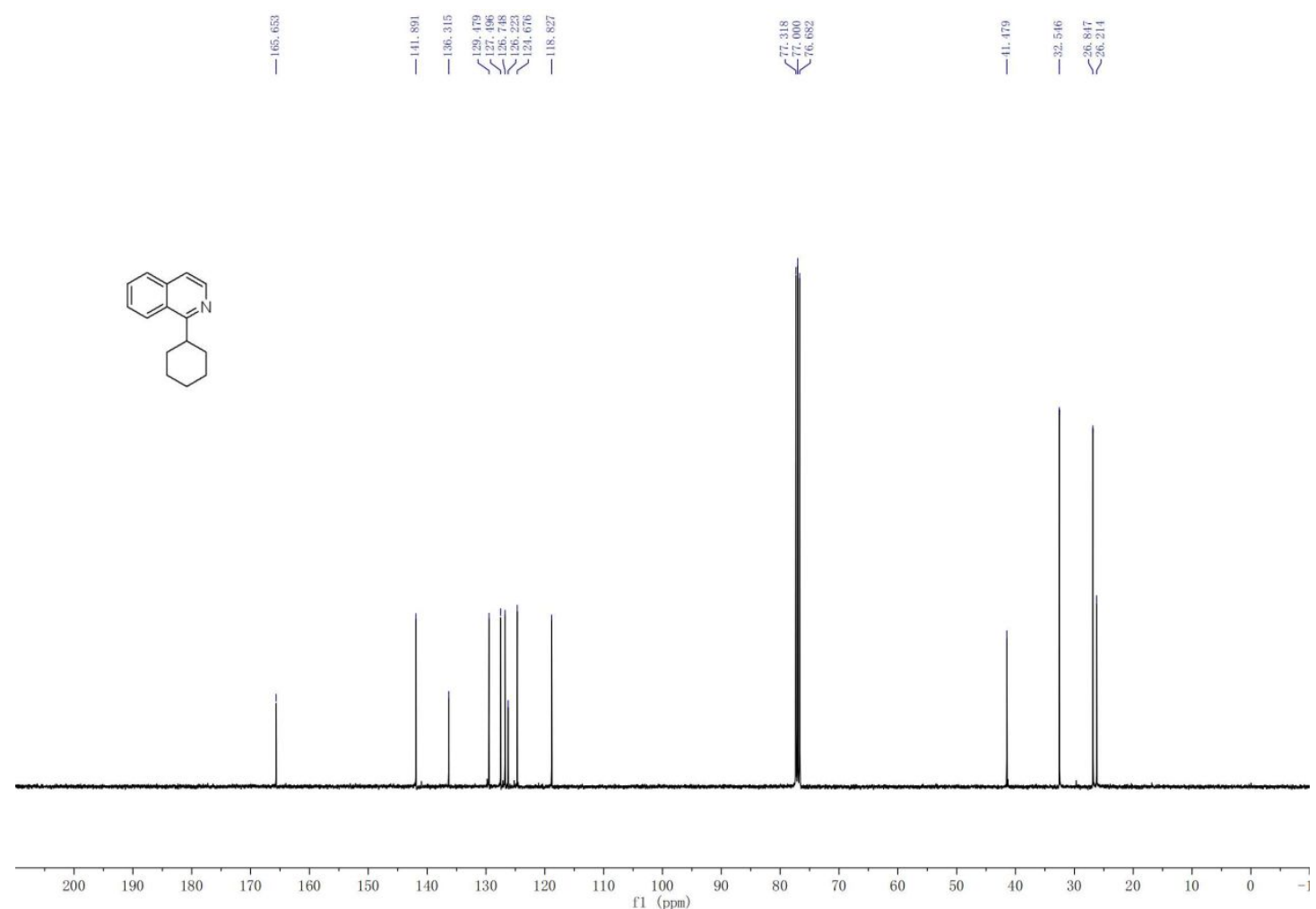

Figure S73. ${ }^{13} \mathrm{C}$ NMR Spectra of $\mathbf{6 a}$ 


\section{1-cyclopentylisoquinoline (6b)}

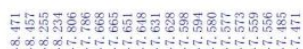

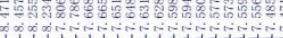
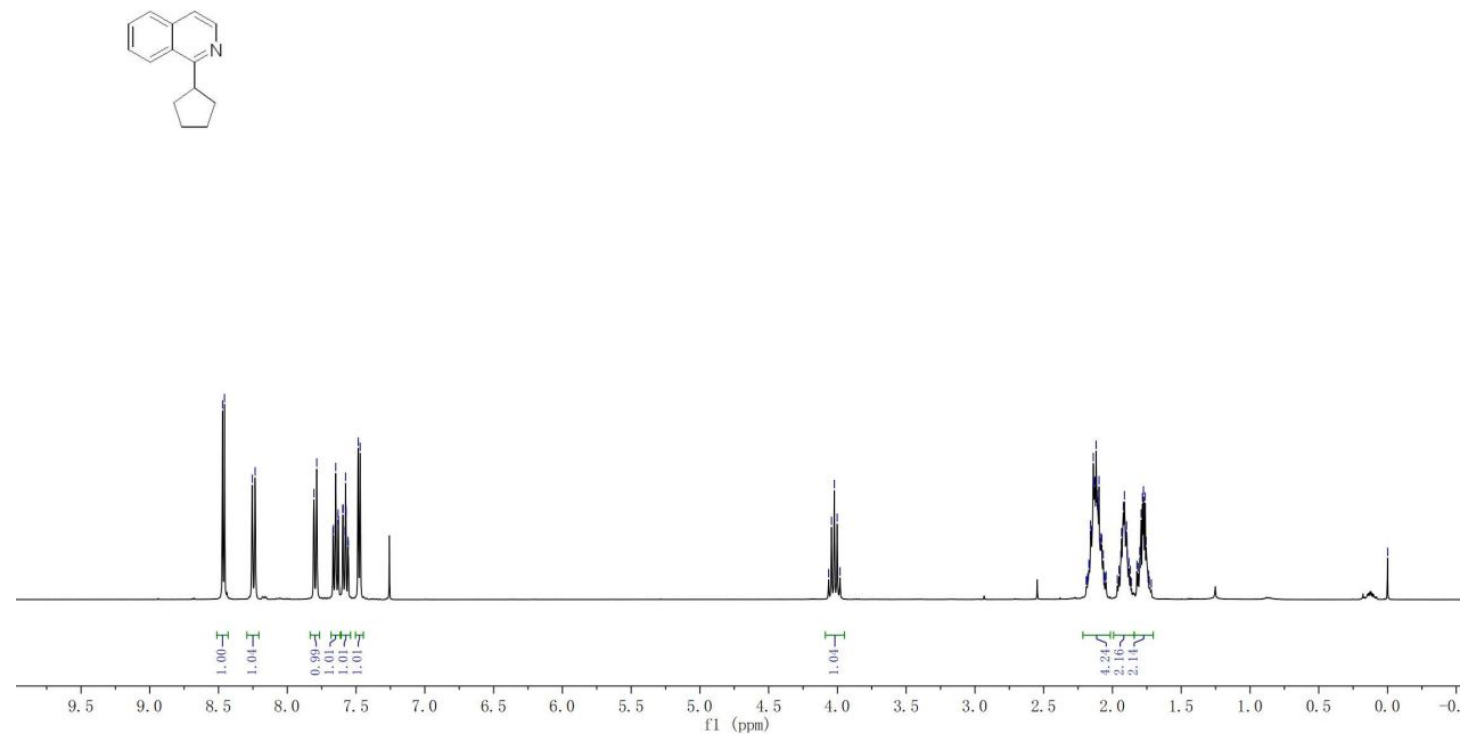

Figure S74. ${ }^{1} \mathrm{H}$ NMR Spectra of $\mathbf{6 b}$

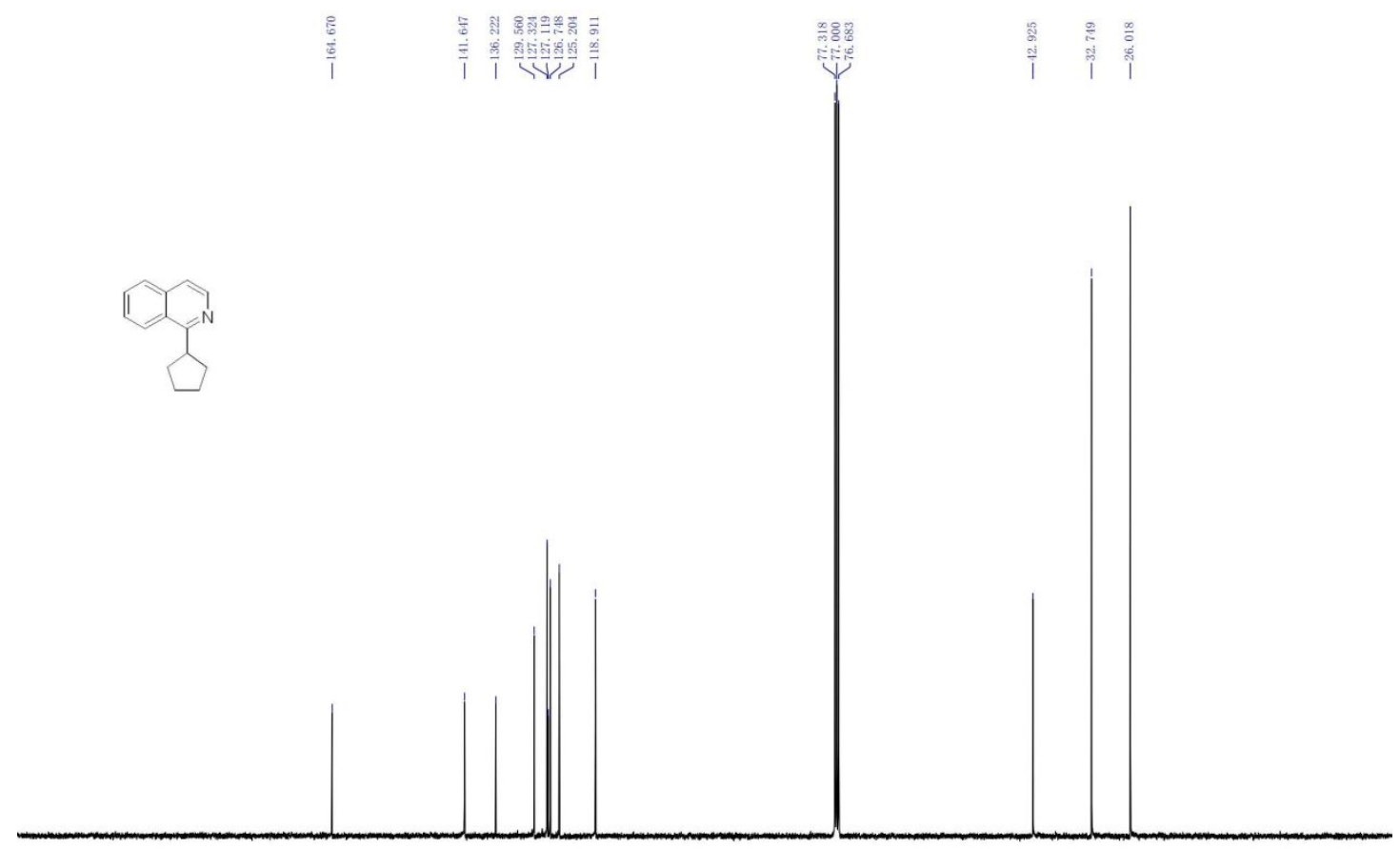

$\begin{array}{lllllll}210 & 200 & 190 & 180 & 170 & 160 & 150\end{array}$

Figure S75. ${ }^{13} \mathrm{C}$ NMR Spectra of $\mathbf{6 b}$ 


\section{1-cyclobutylisoquinoline (6c)}

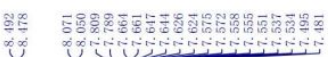

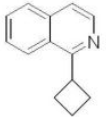

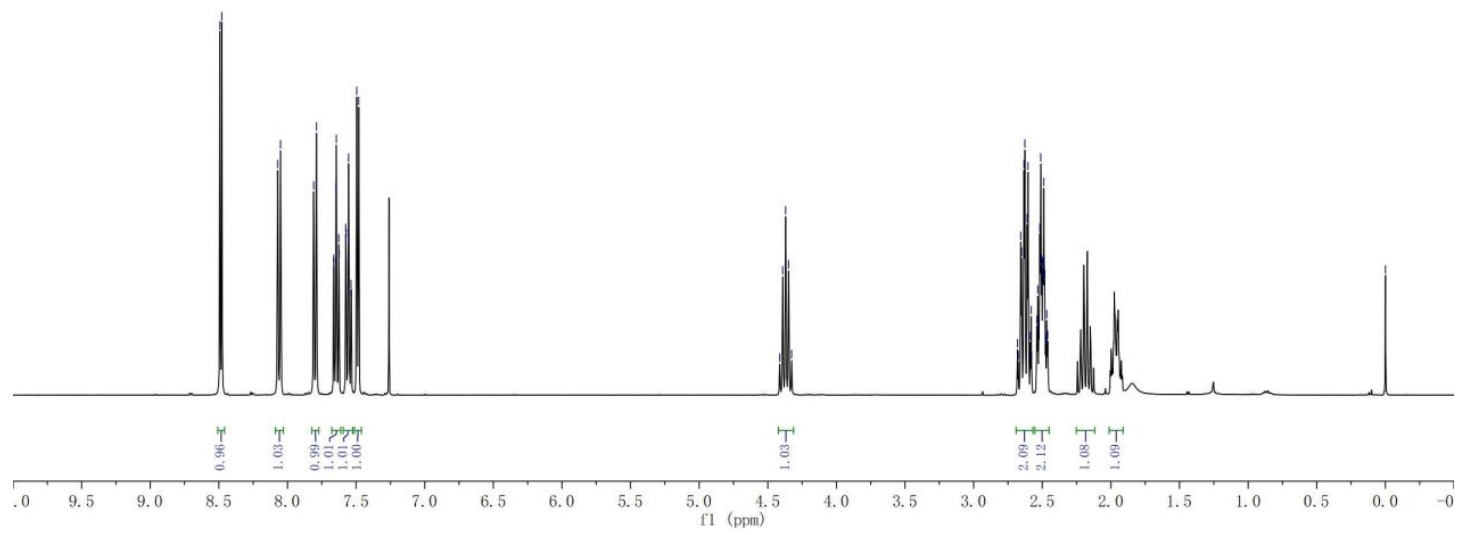

Figure S76. ${ }^{1} \mathrm{H}$ NMR Spectra of $\mathbf{6 c}$

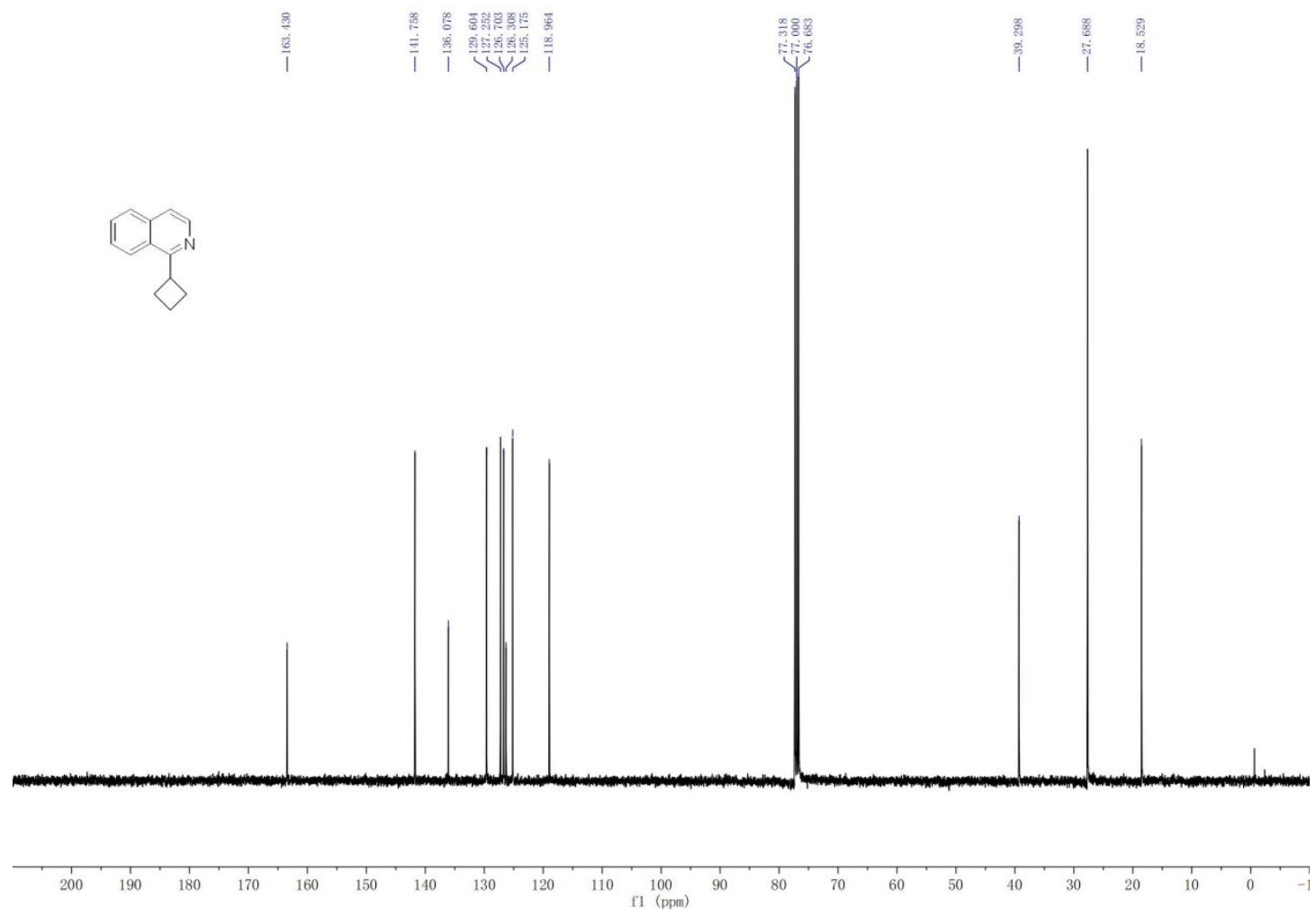

Figure S77. ${ }^{13} \mathrm{C}$ NMR Spectra of $\mathbf{6 c}$ 


\section{1-pentylisoquinoline (6e)}

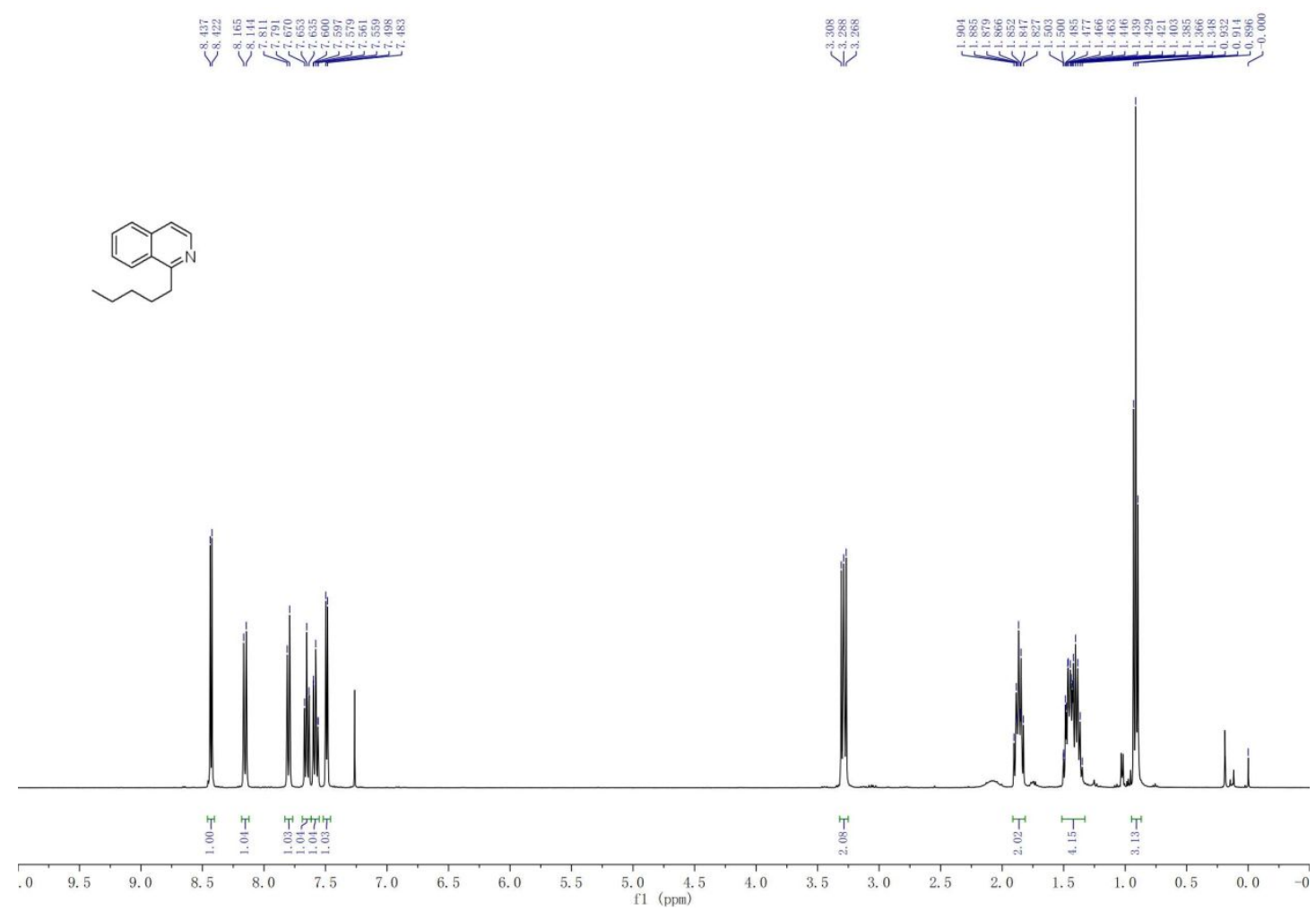

Figure S80. ${ }^{1} \mathrm{H}$ NMR Spectra of $\mathbf{6 e}$

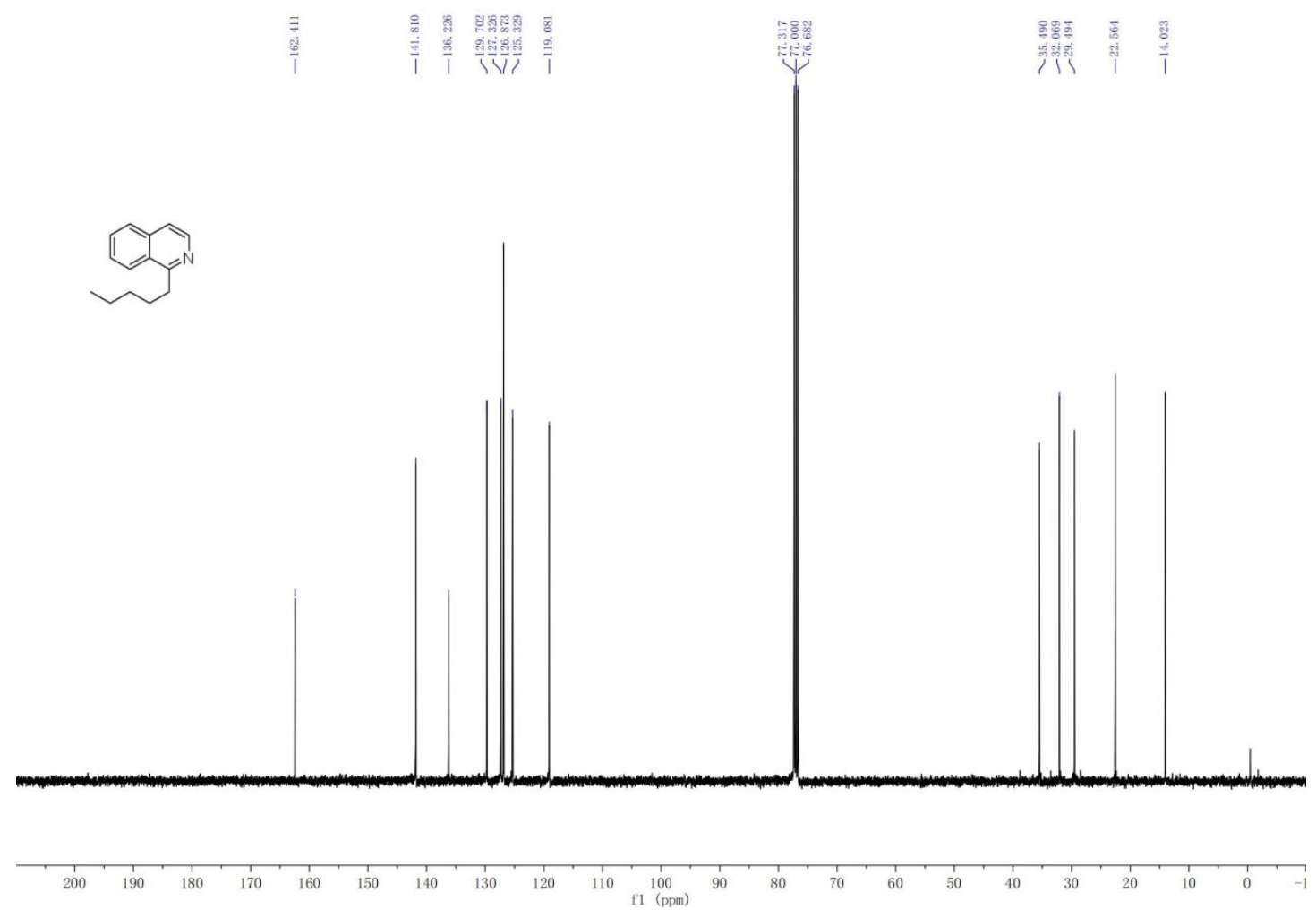

Figure S81. ${ }^{13} \mathrm{C}$ NMR Spectra of $6 \mathbf{e}$ 
1-hexylisoquinoline (6f)

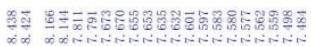

Y Y
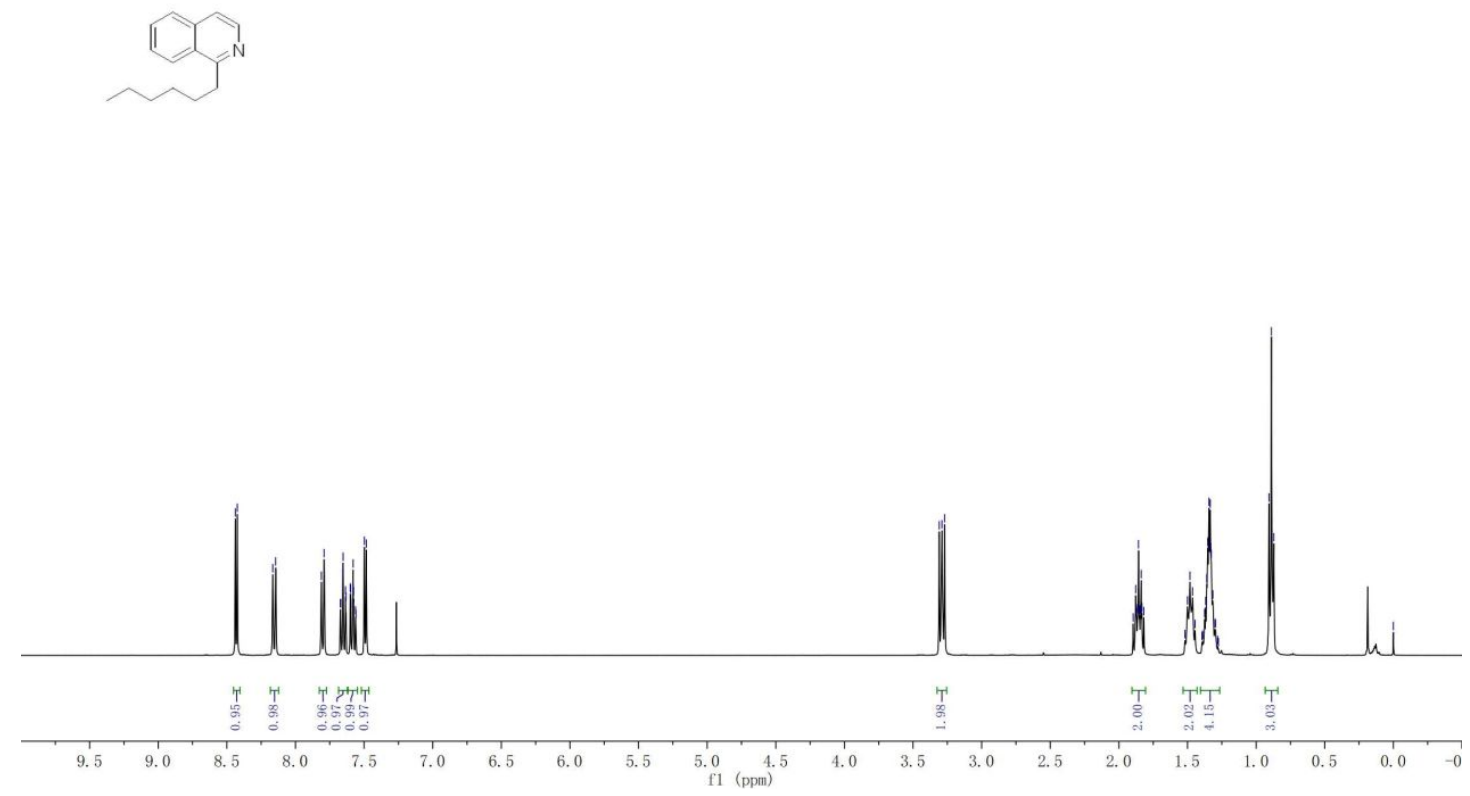

Figure S82. ${ }^{1} \mathrm{H}$ NMR Spectra of $\mathbf{6} \mathbf{f}$

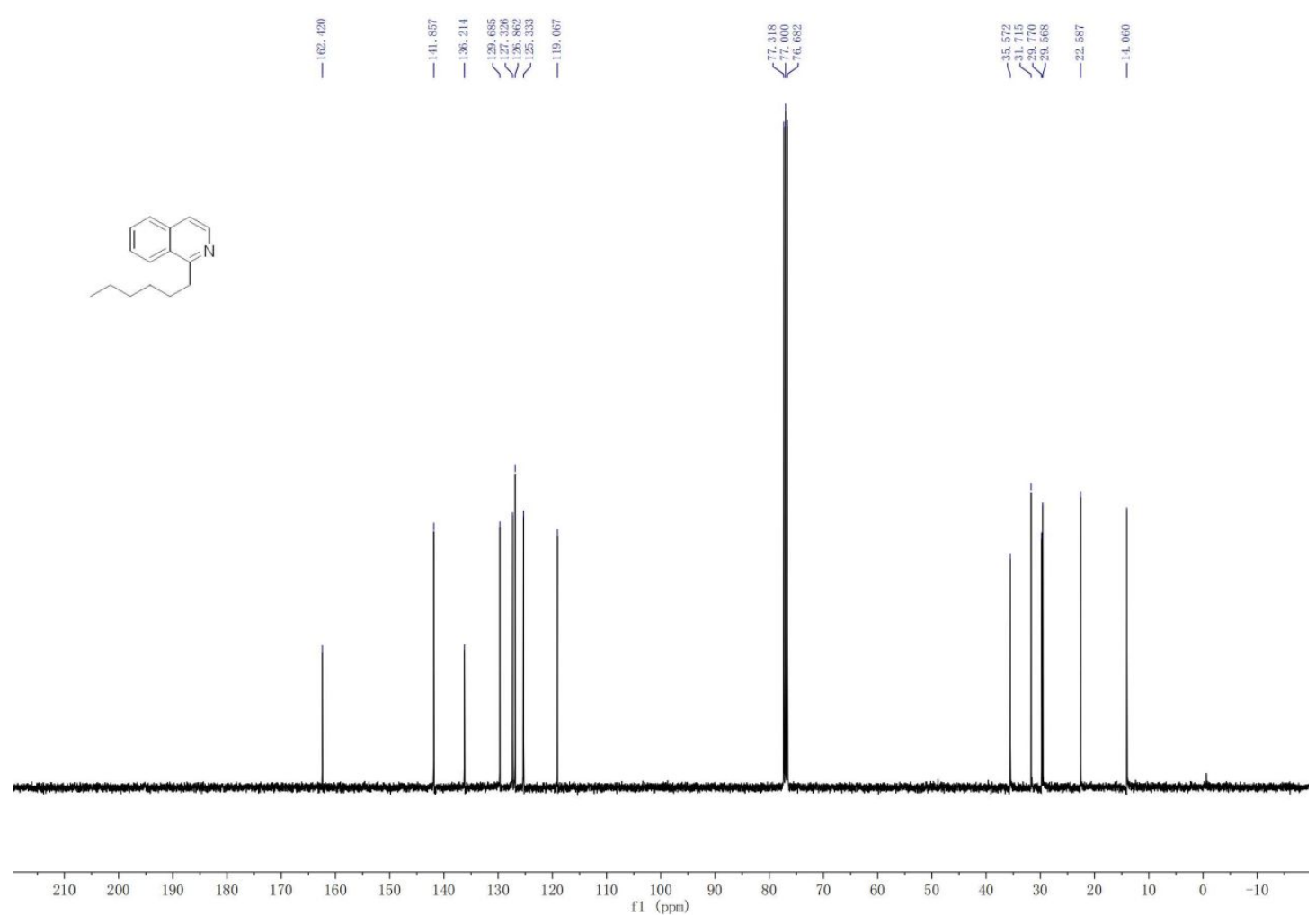

Figure S83. ${ }^{13} \mathrm{C}$ NMR Spectra of $\mathbf{6 f}$ 
1-decylisoquinoline (6g)

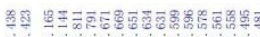

४⿻

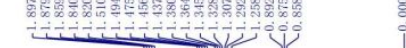

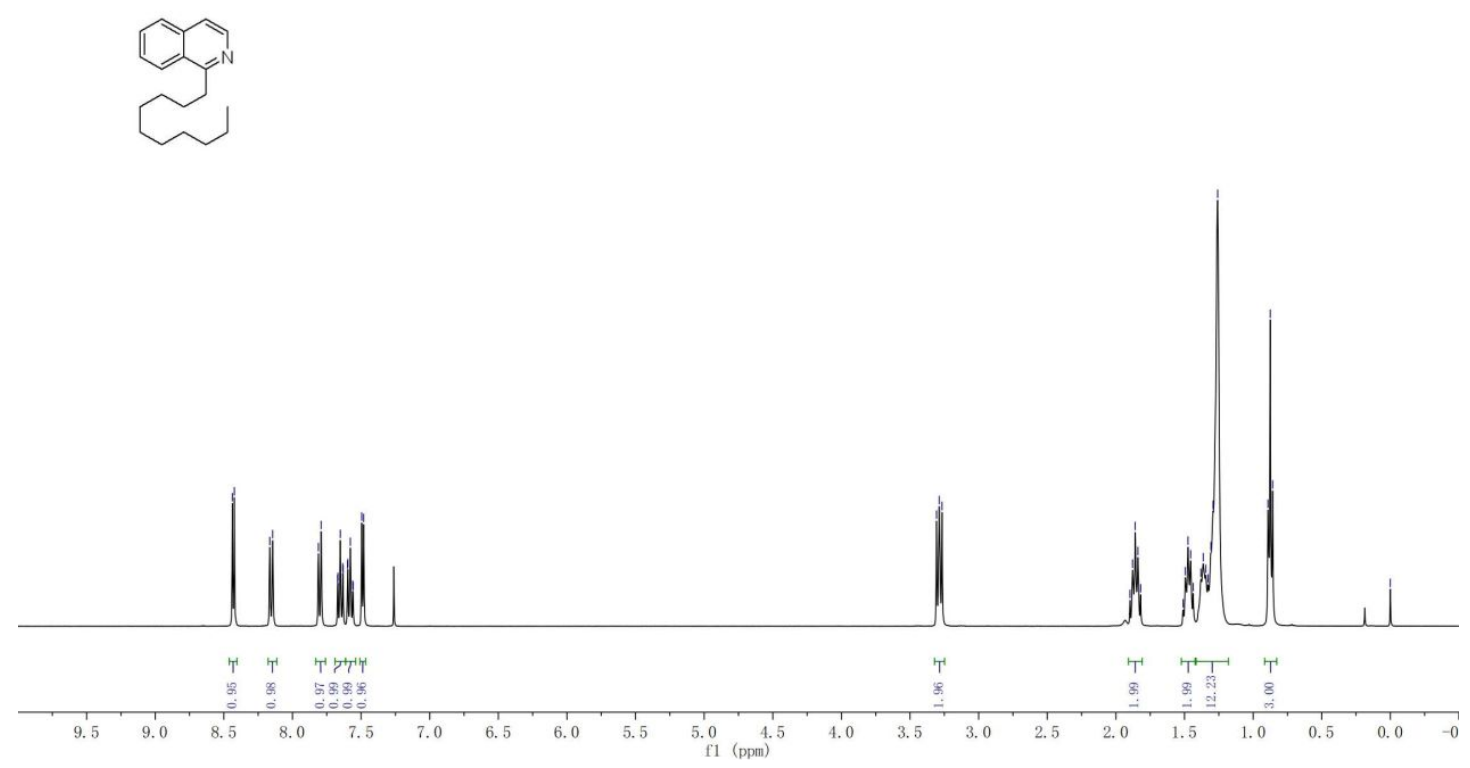

Figure S84. ${ }^{1} \mathrm{H}$ NMR Spectra of $\mathbf{6 g}$

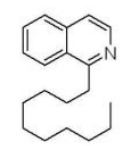

$\mid$
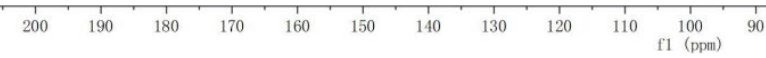

Figure S85. ${ }^{13} \mathrm{C}$ NMR Spectra of $\mathbf{6 g}$ 
1-isobutylisoquinoline (6h)

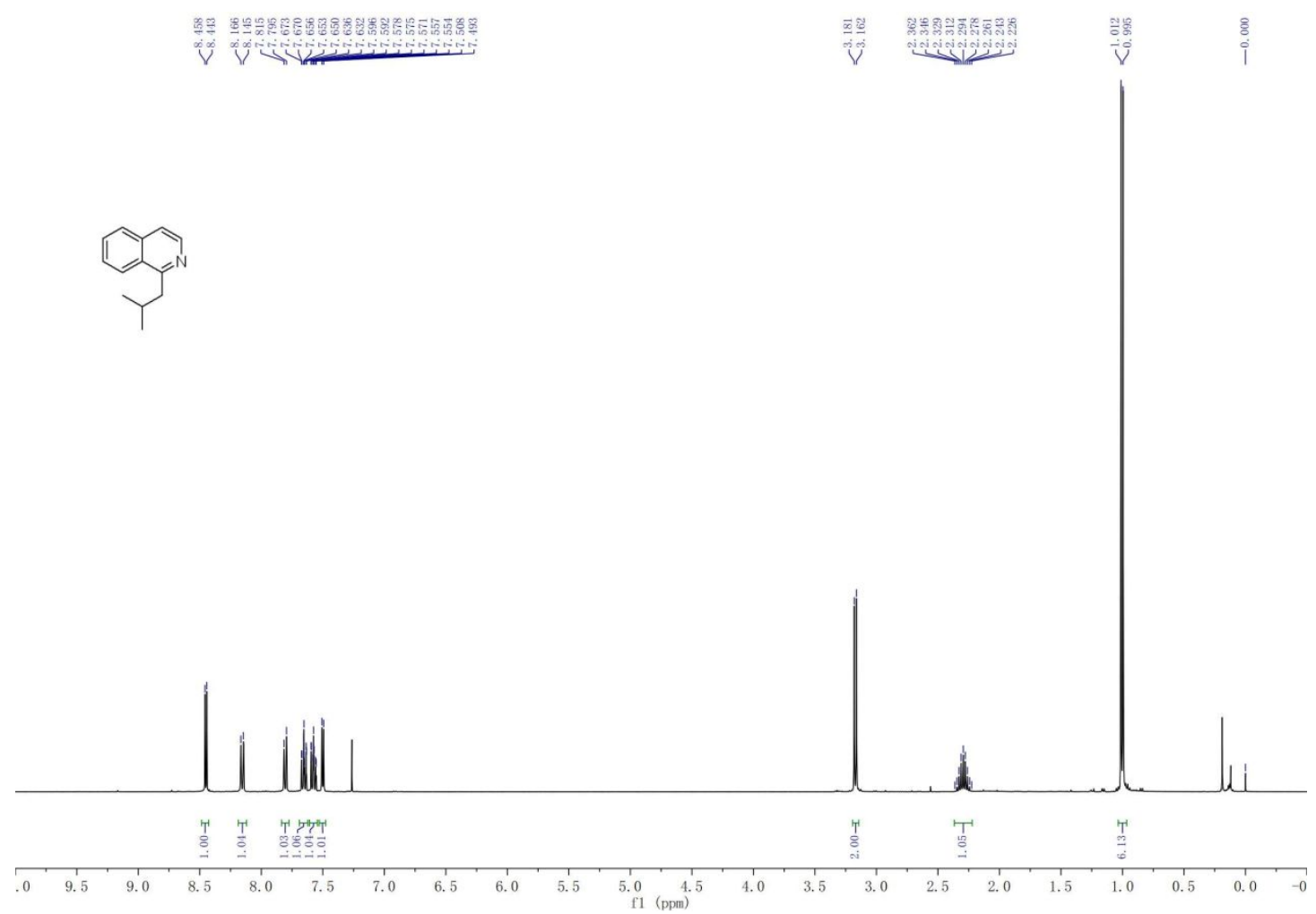

Figure S86. ${ }^{1} \mathrm{H}$ NMR Spectra of $\mathbf{6 h}$

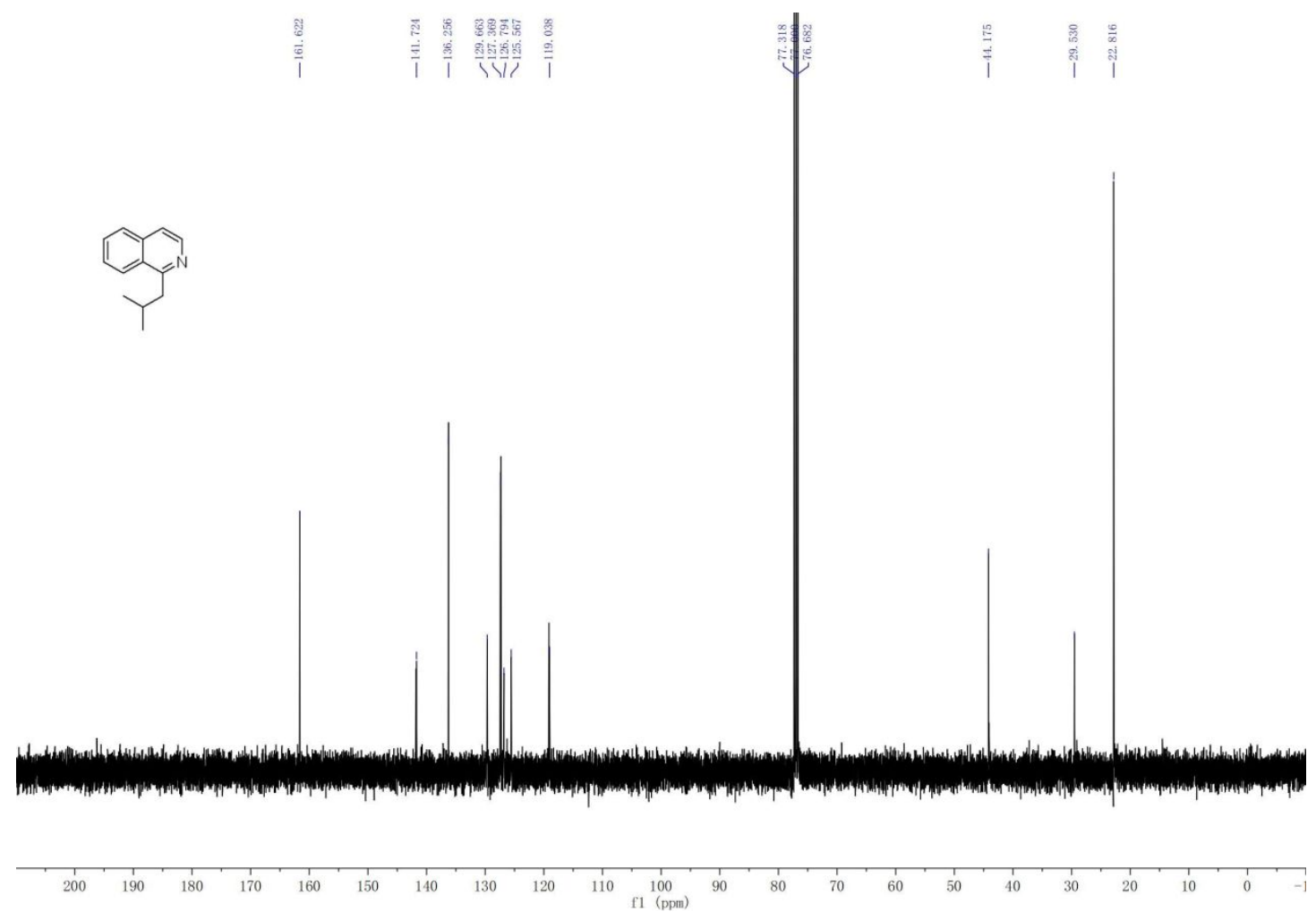

Figure S87. ${ }^{13} \mathrm{C}$ NMR Spectra of $\mathbf{6 h}$ 
1-isopropylisoquinoline (6i)
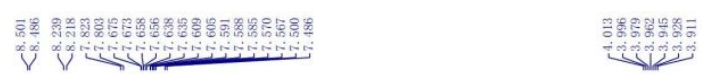

V

ষे
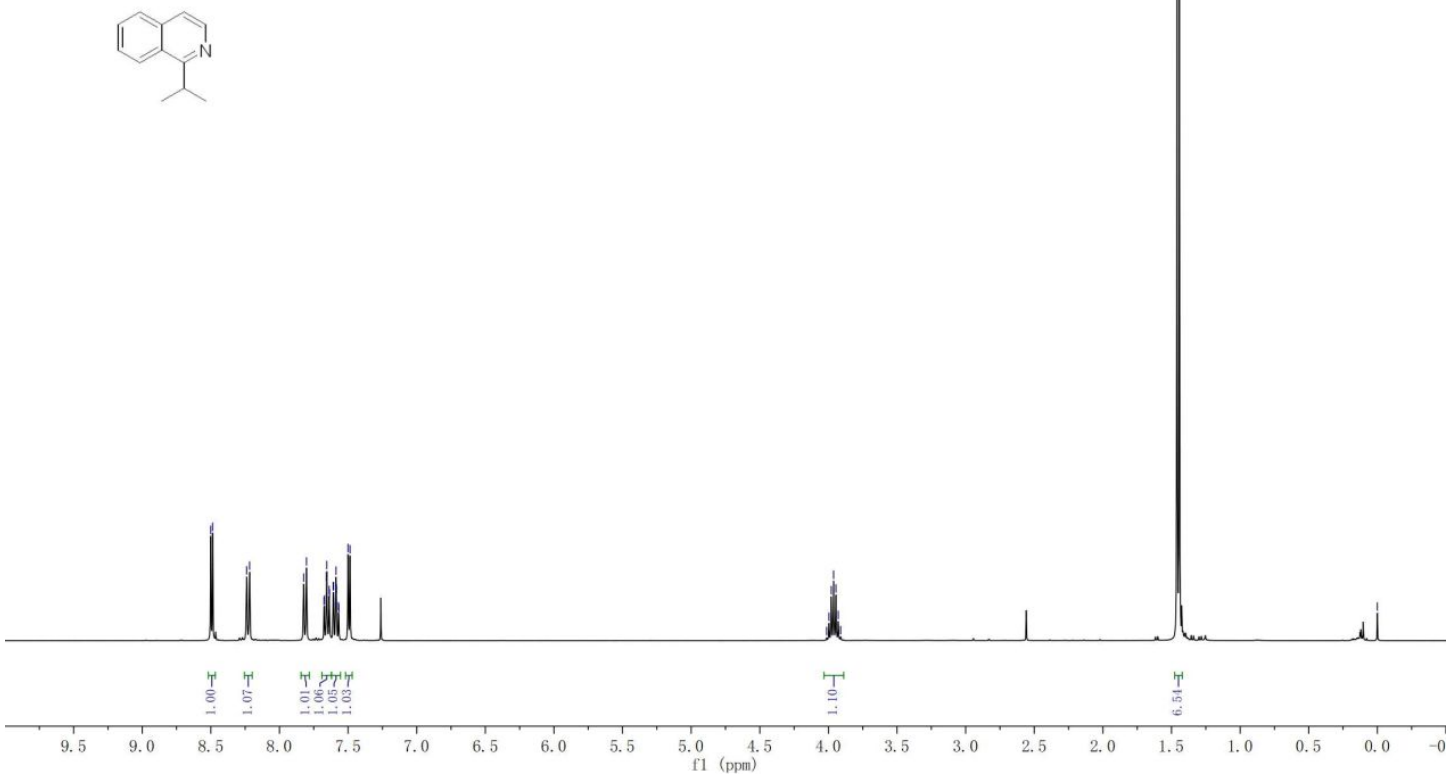

Figure S88. ${ }^{1} \mathrm{H}$ NMR Spectra of $\mathbf{6 i}$

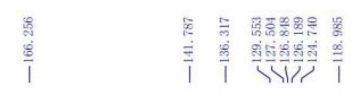

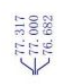
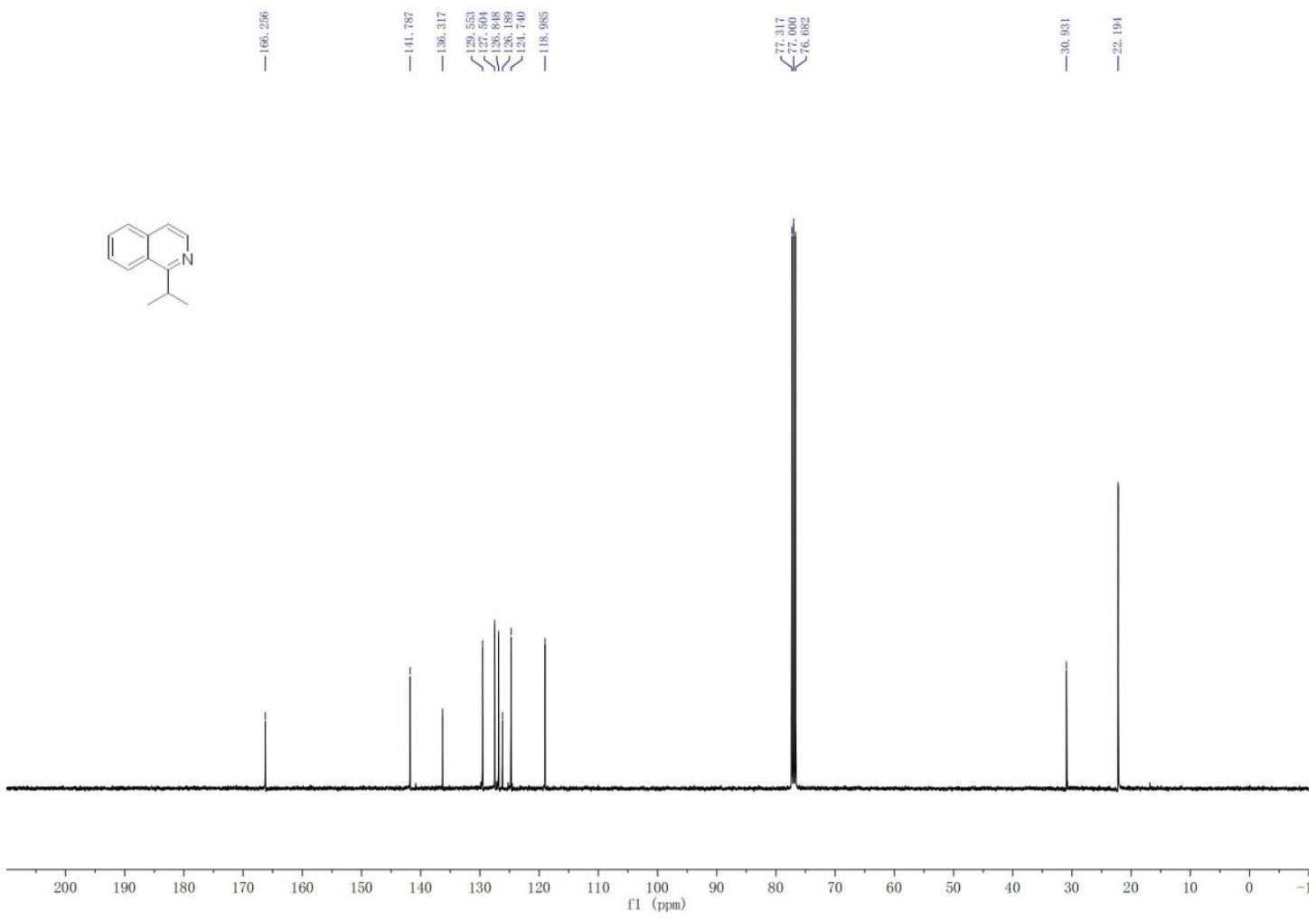

Figure S89. ${ }^{13} \mathrm{C}$ NMR Spectra of $\mathbf{6 i}$

S53 
1-(sec-butyl)isoquinoline (6j)

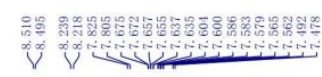

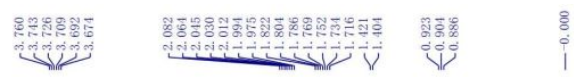

武

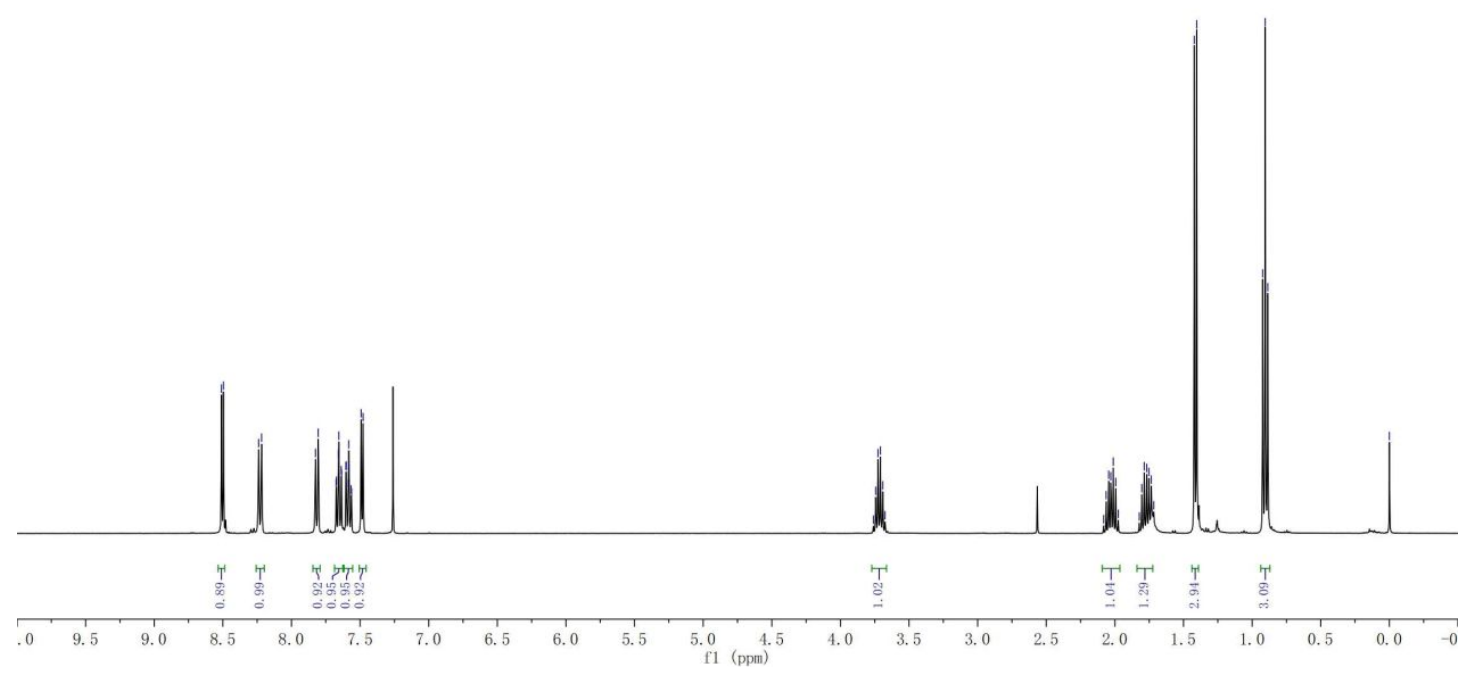

Figure S90. ${ }^{1} \mathrm{H}$ NMR Spectra of $\mathbf{6 j}$

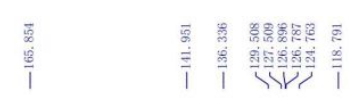

IN

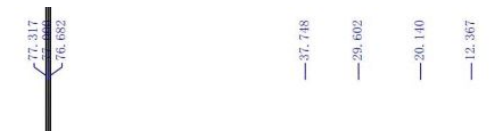

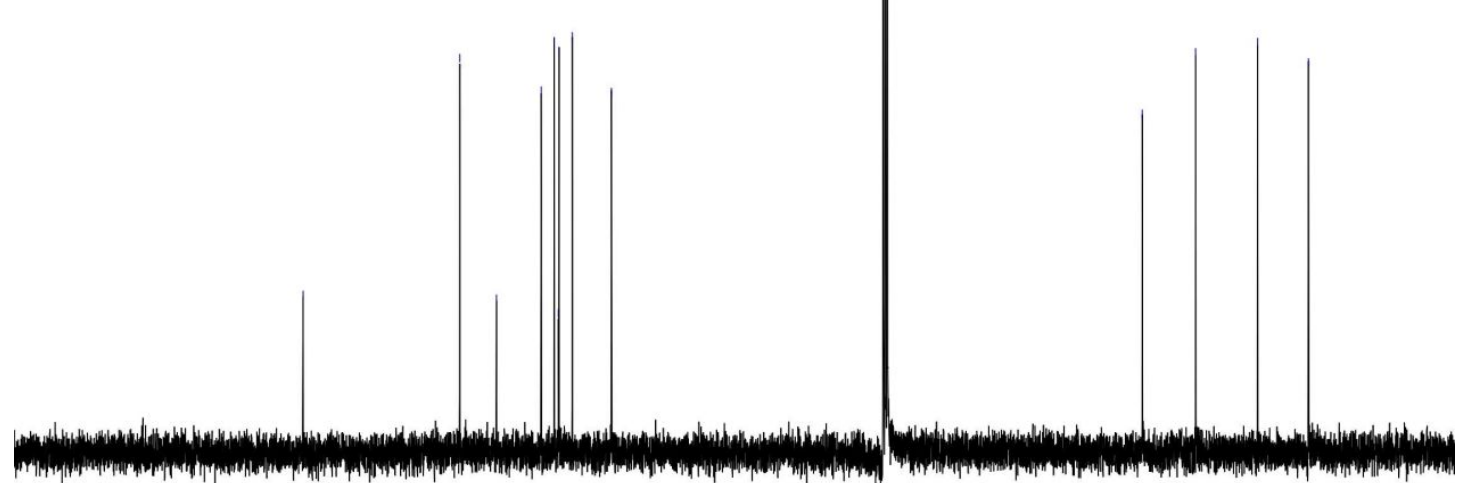

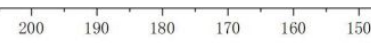

Figure S91. ${ }^{13} \mathrm{C}$ NMR Spectra of $\mathbf{6 j}$ 


\section{1-(2-cyclohexylethyl)isoquinoline (6k)}

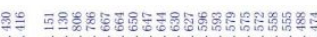

Y)

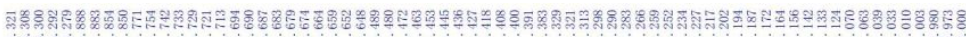
(2)

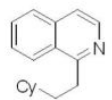

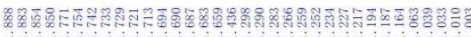

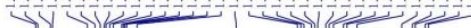
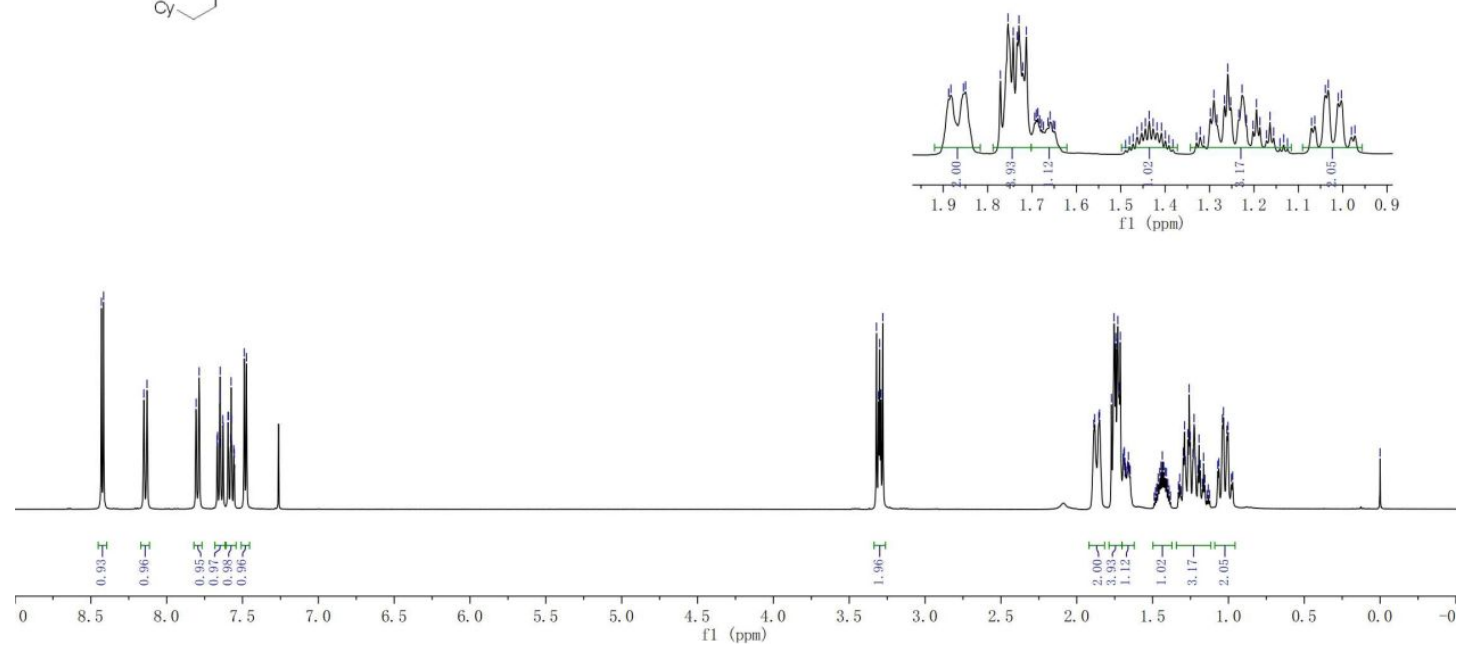

Figure S92. ${ }^{1} \mathrm{H}$ NMR Spectra of $6 \mathbf{k}$

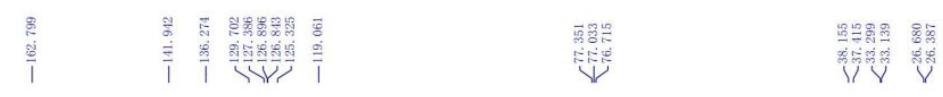

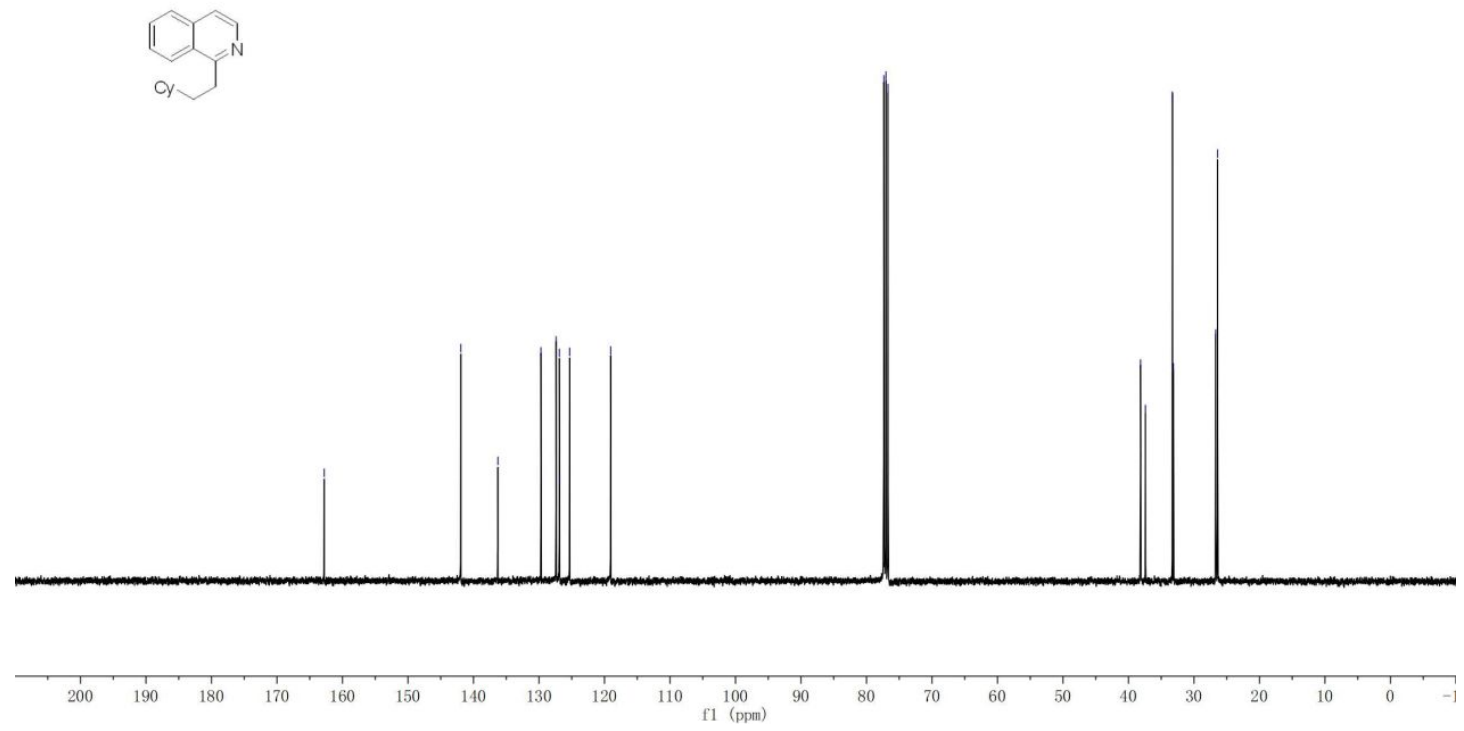

Figure S93. ${ }^{13} \mathrm{C}$ NMR Spectra of $6 \mathbf{k}$ 
1-benzylisoquinoline (6I)

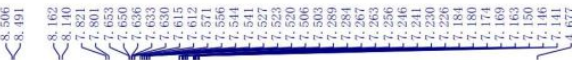

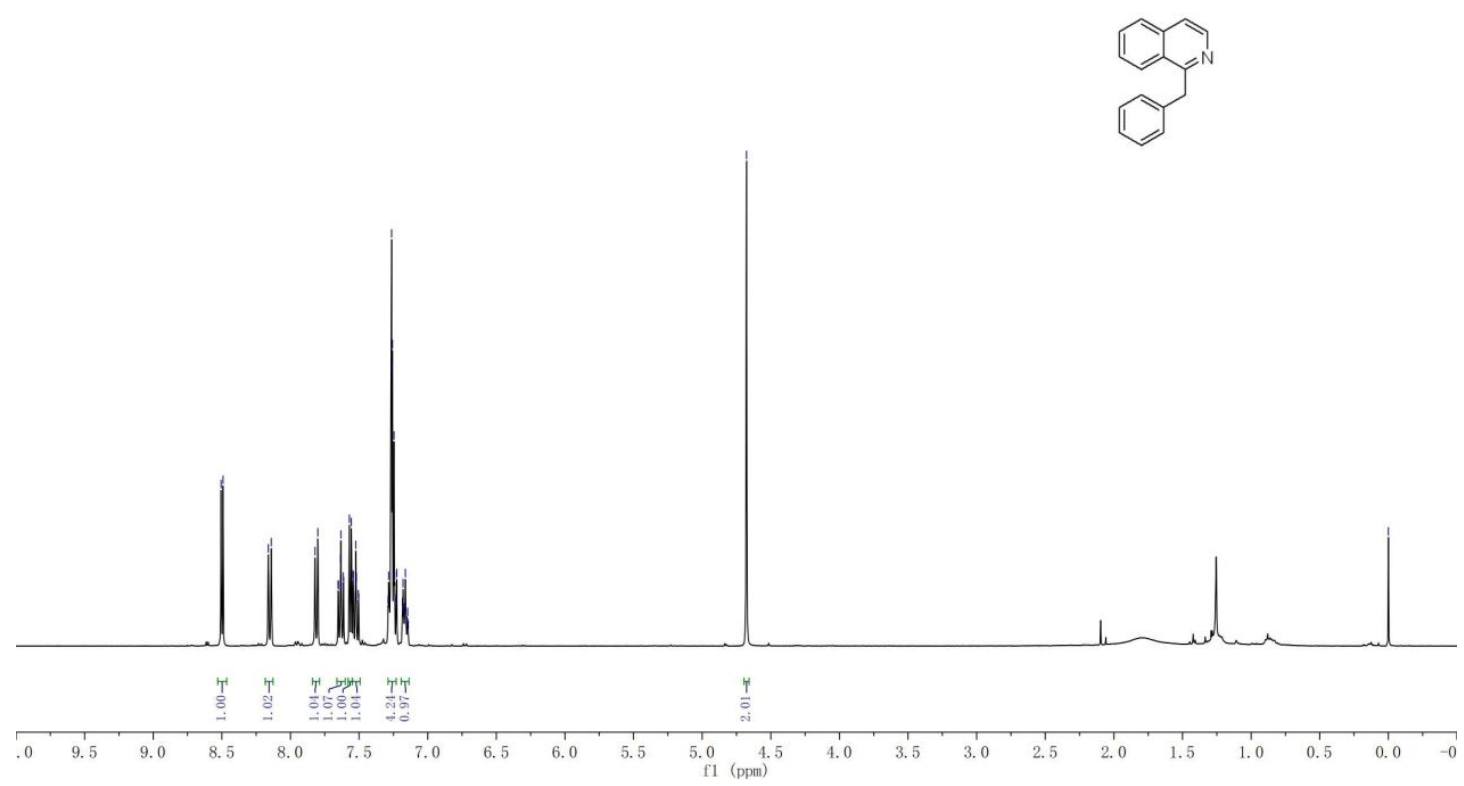

Figure S94. ${ }^{1} \mathrm{H}$ NMR Spectra of 61

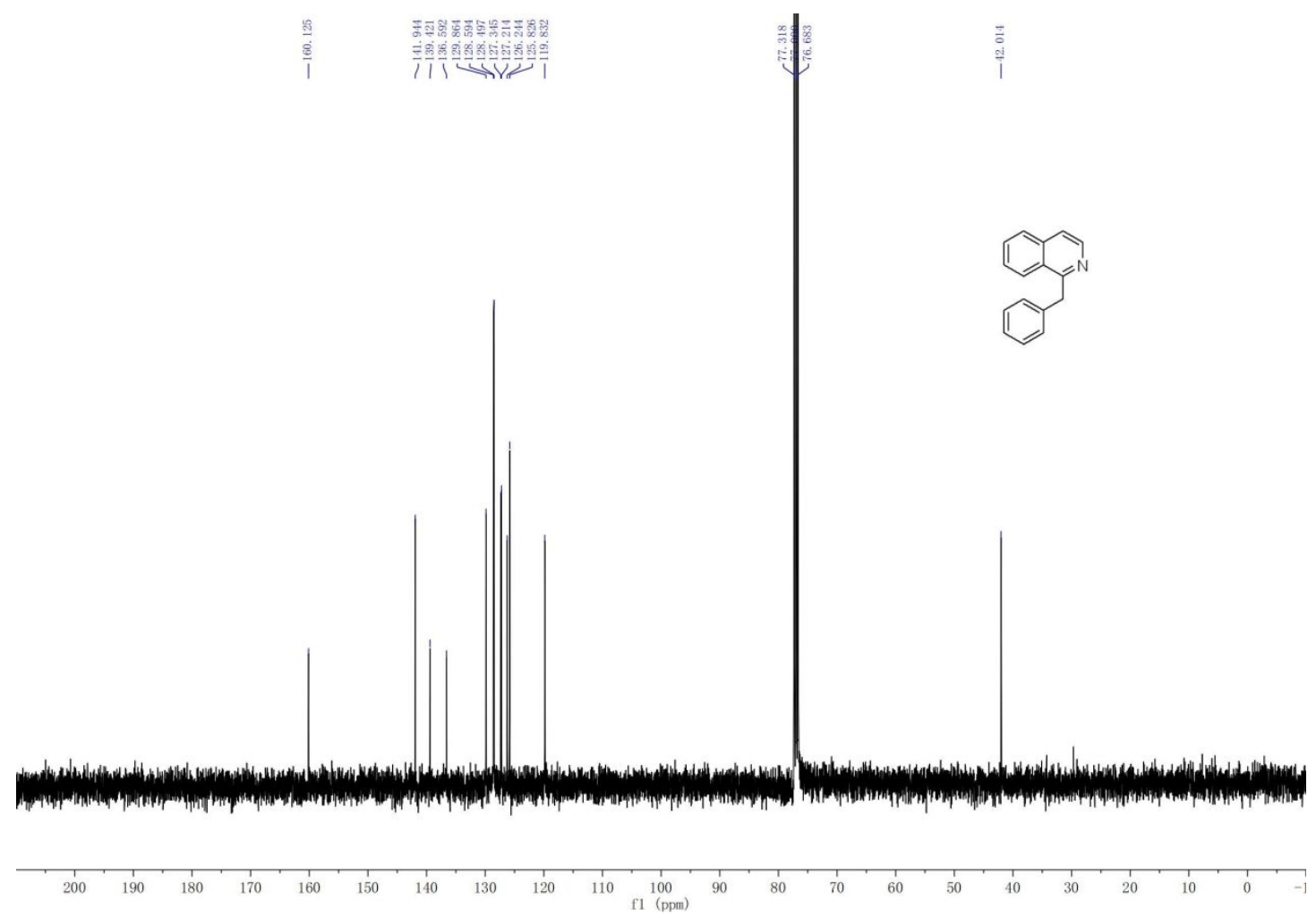

Figure S95. ${ }^{13} \mathrm{C}$ NMR Spectra of 61 
1-phenethylisoquinoline (6m)

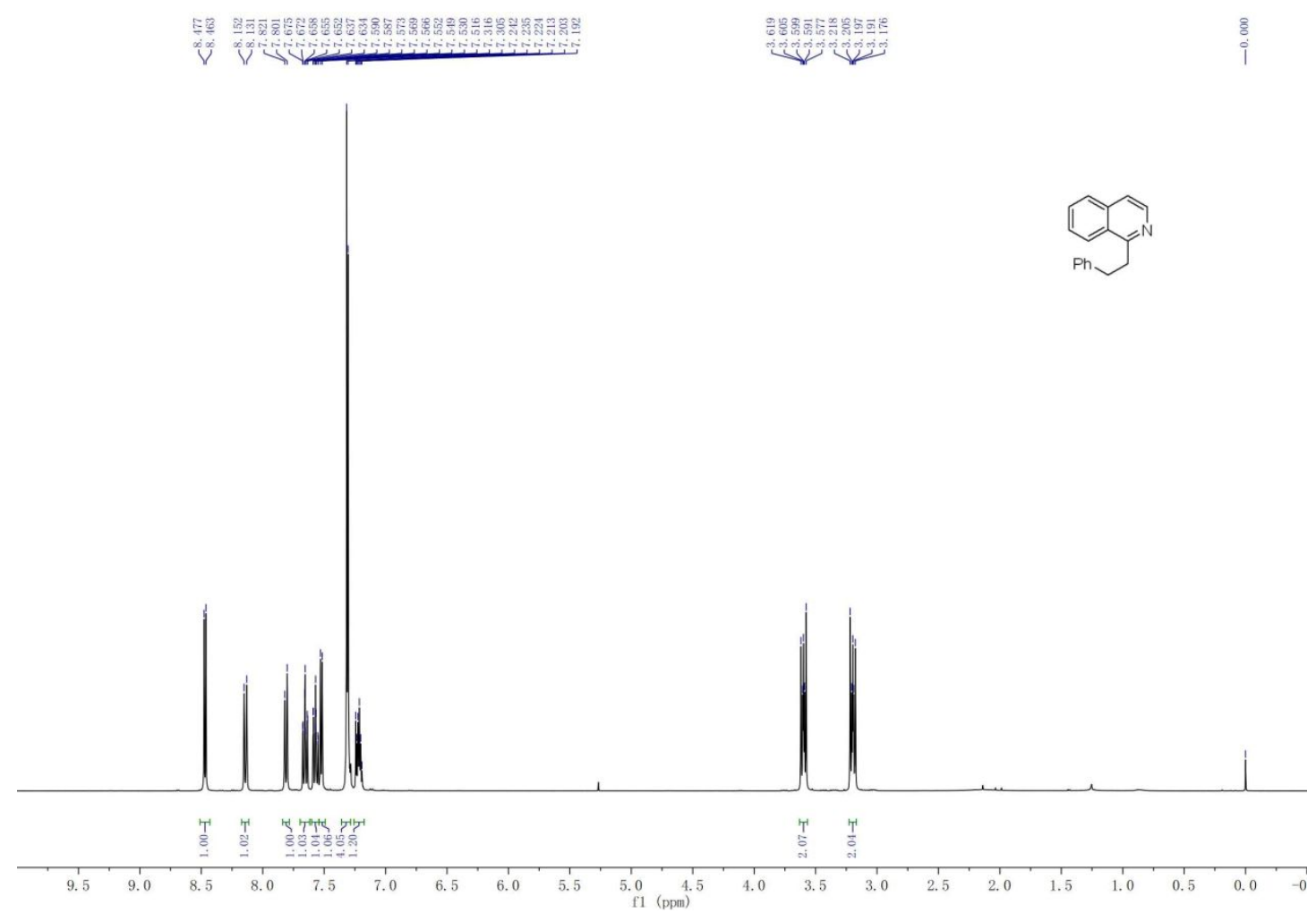

Figure S96. ${ }^{1} \mathrm{H}$ NMR Spectra of $\mathbf{6 m}$

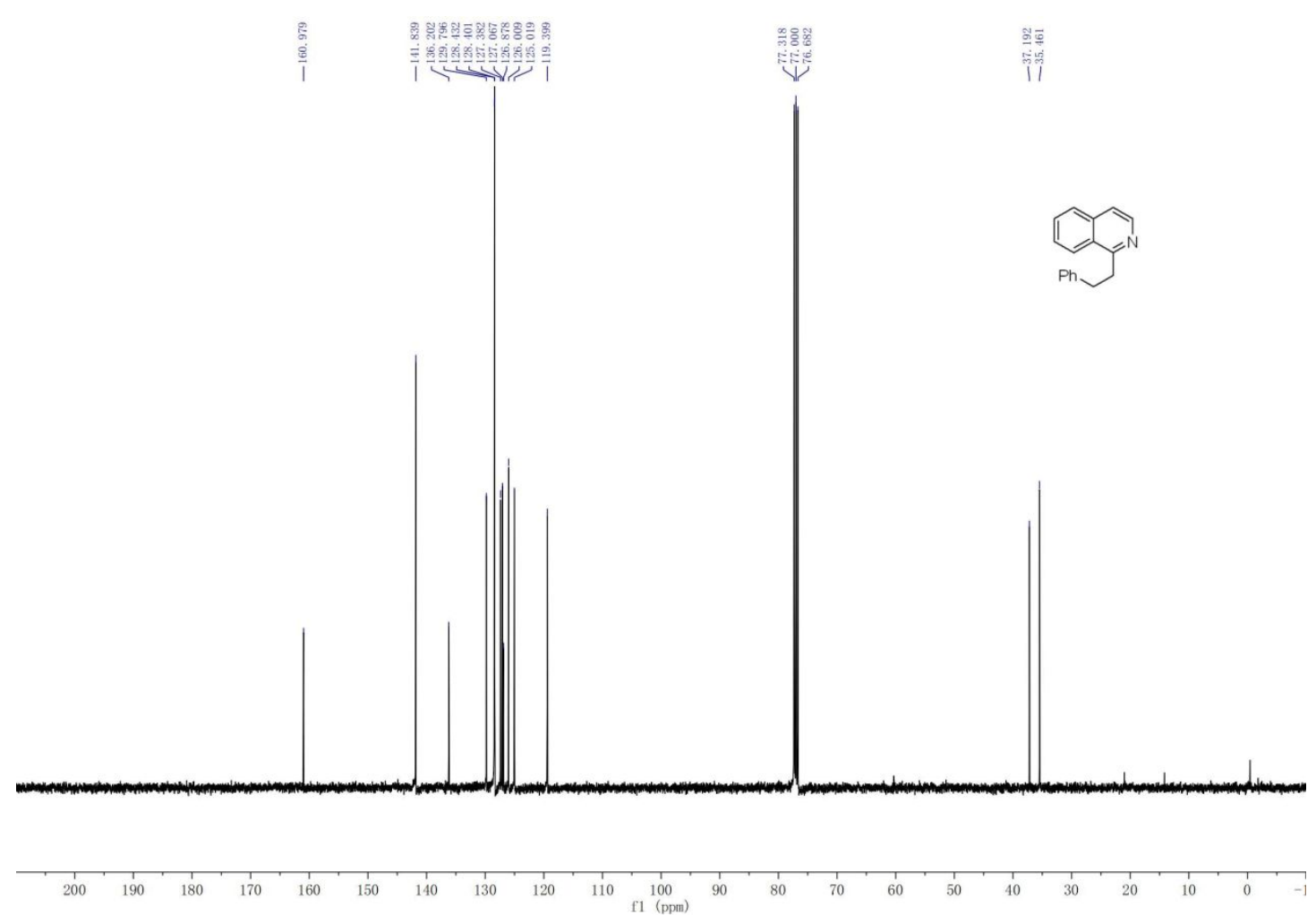

Figure S97. ${ }^{13} \mathrm{C}$ NMR Spectra of $\mathbf{6 m}$ 


\section{1-(3-phenylpropyl)isoquinoline (6n)}
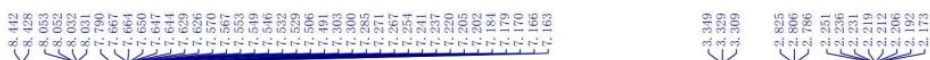

8
0
0
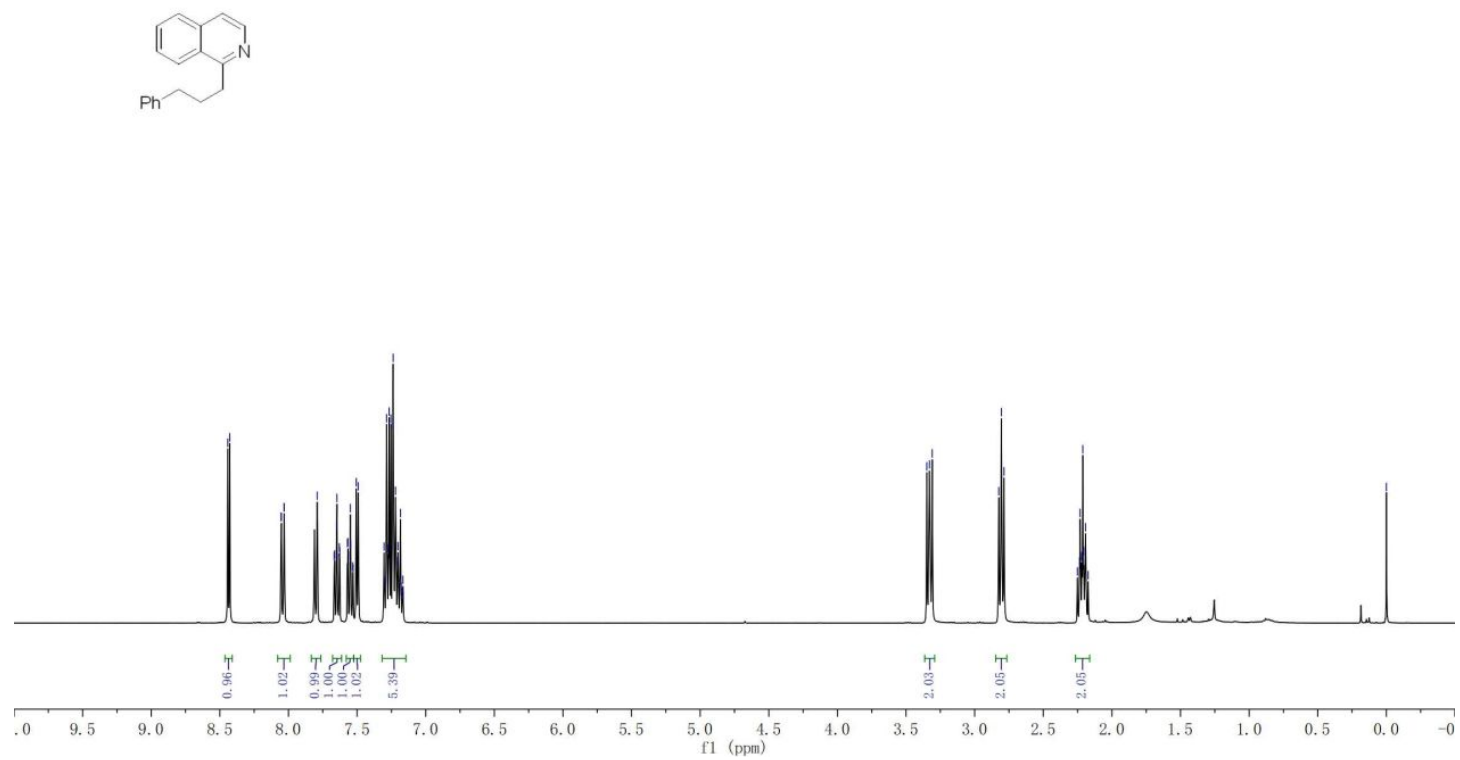

Figure S98. ${ }^{1} \mathrm{H}$ NMR Spectra of $\mathbf{6 n}$

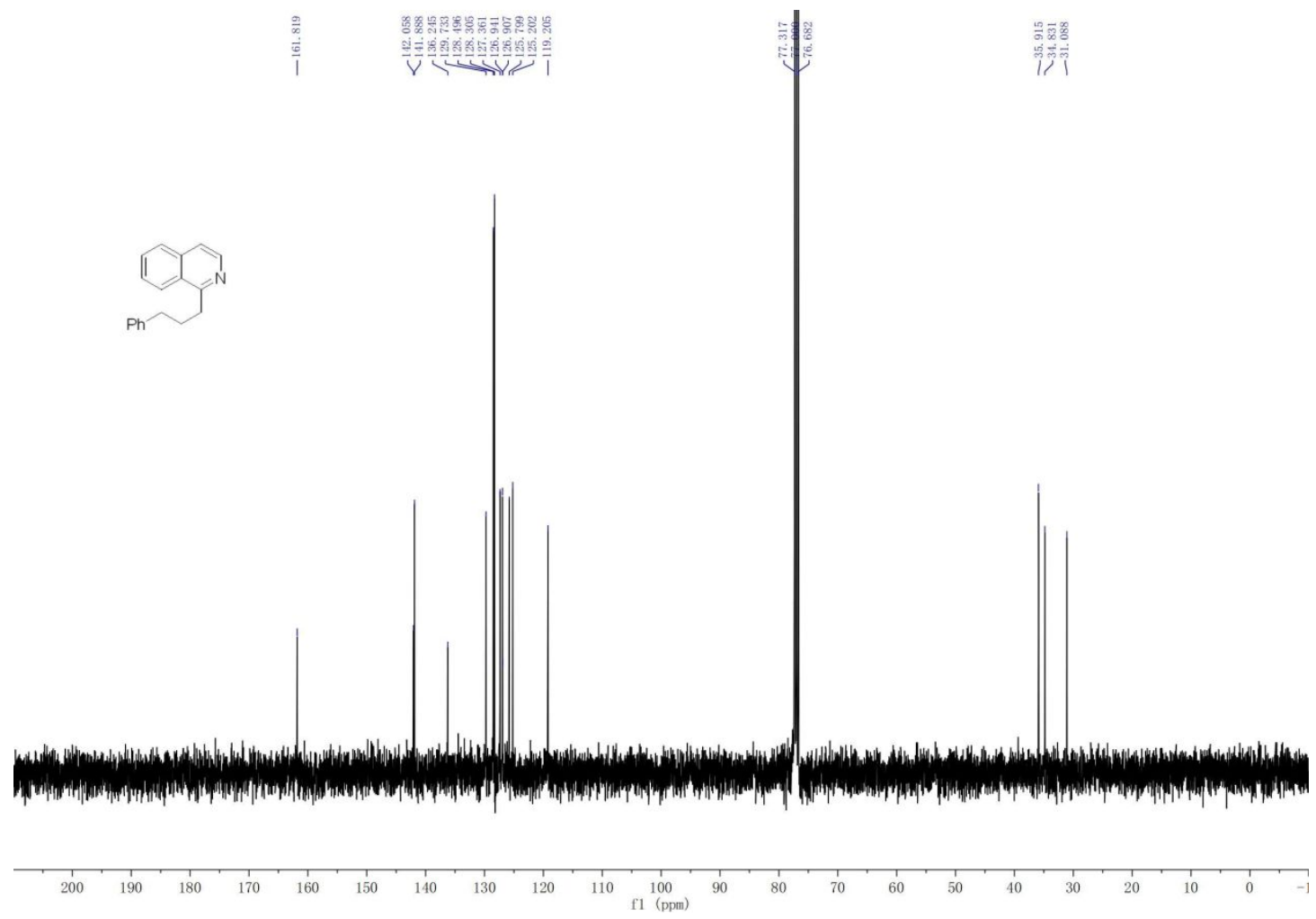

Figure S99. ${ }^{13} \mathrm{C}$ NMR Spectra of $6 n$ 
1-(but-3-en-1-yl)isoquinoline (6o)

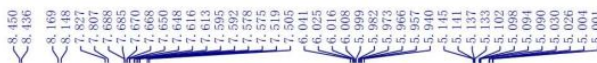

요요ำ
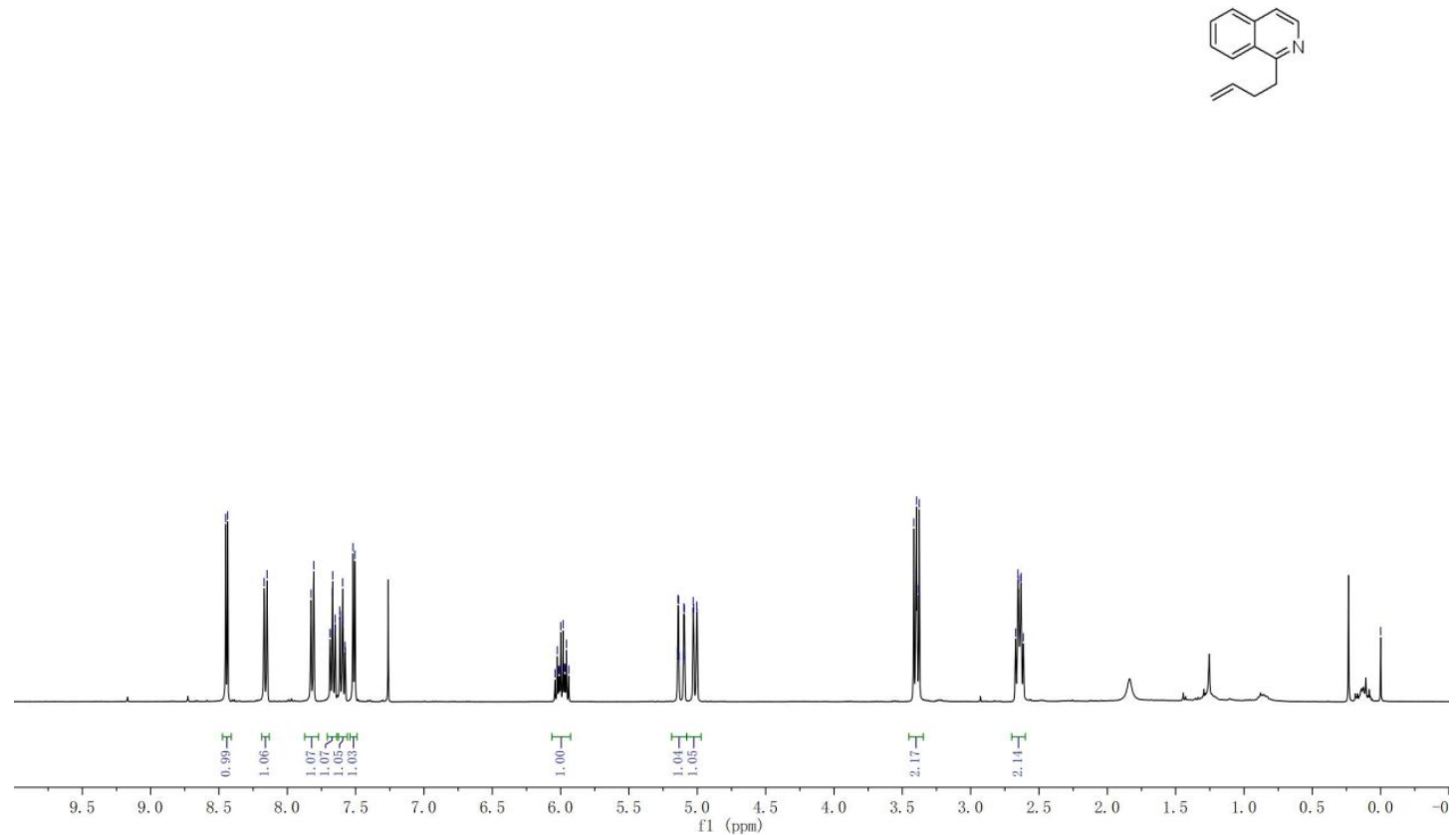

Figure S100. ${ }^{1} \mathrm{H}$ NMR Spectra of $\mathbf{6 o}$

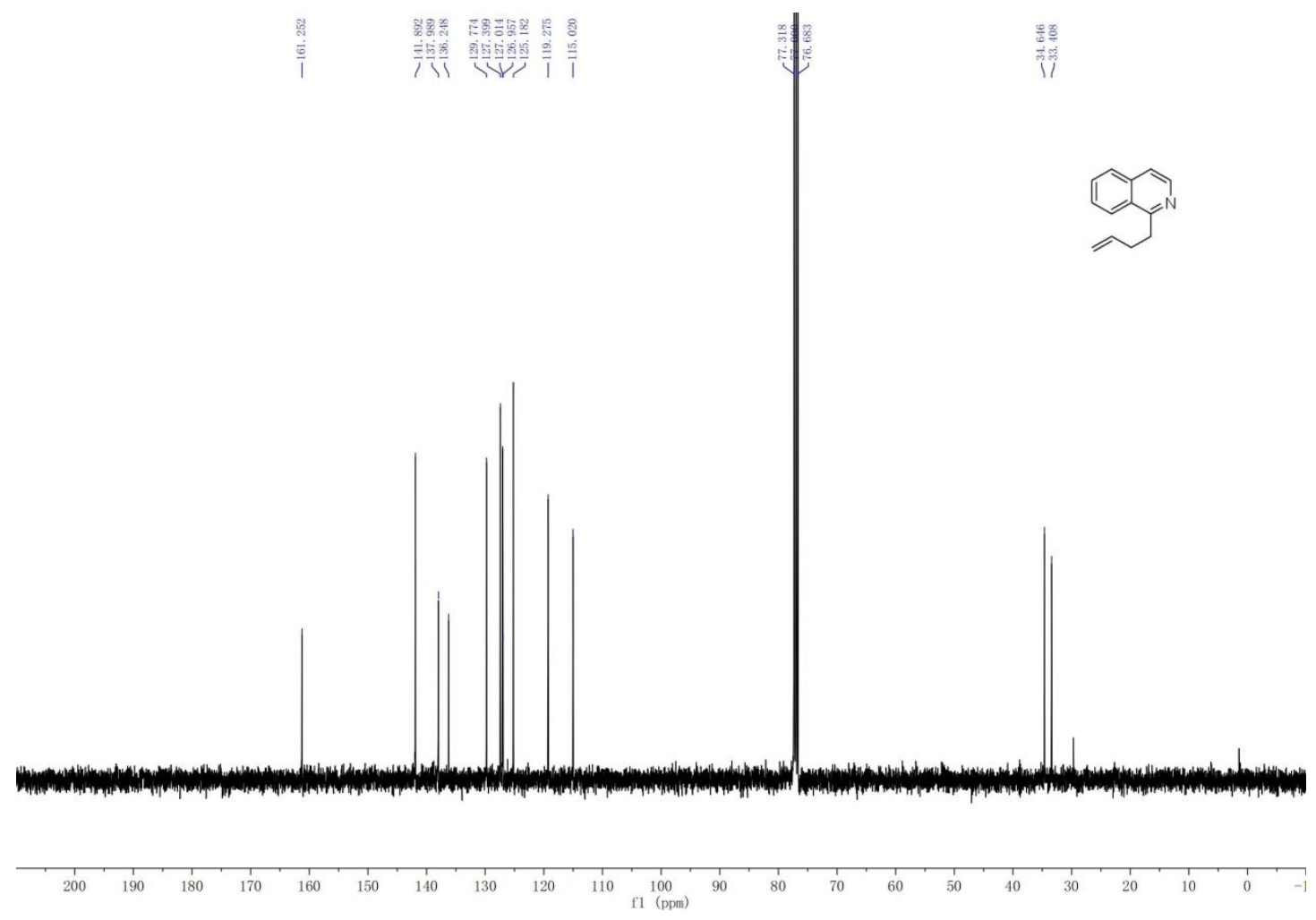

Figure S101. ${ }^{13} \mathrm{C}$ NMR Spectra of $\mathbf{6 o}$ 


\section{1-(pent-4-en-1-yl)isoquinoline (6p)}

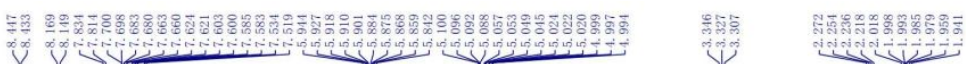
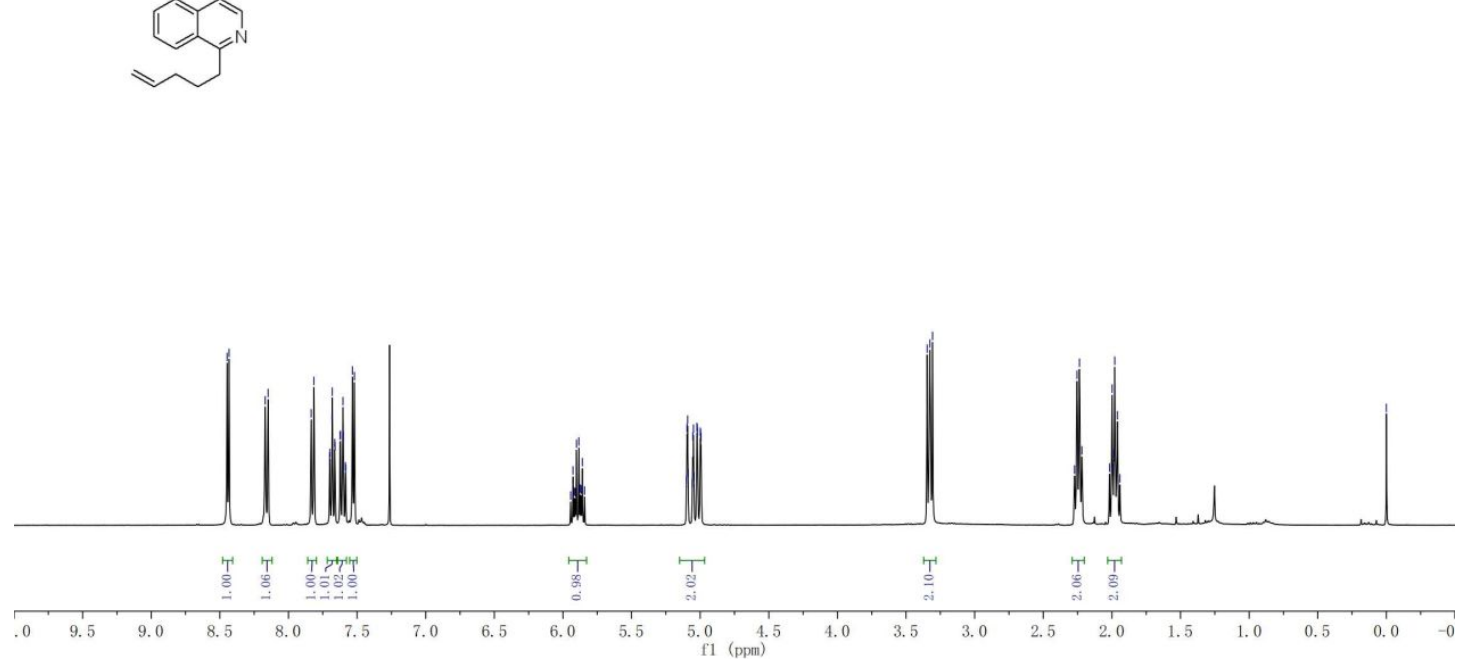

Figure S102. ${ }^{1} \mathrm{H}$ NMR Spectra of $\mathbf{6 p}$

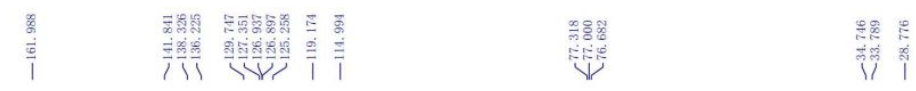

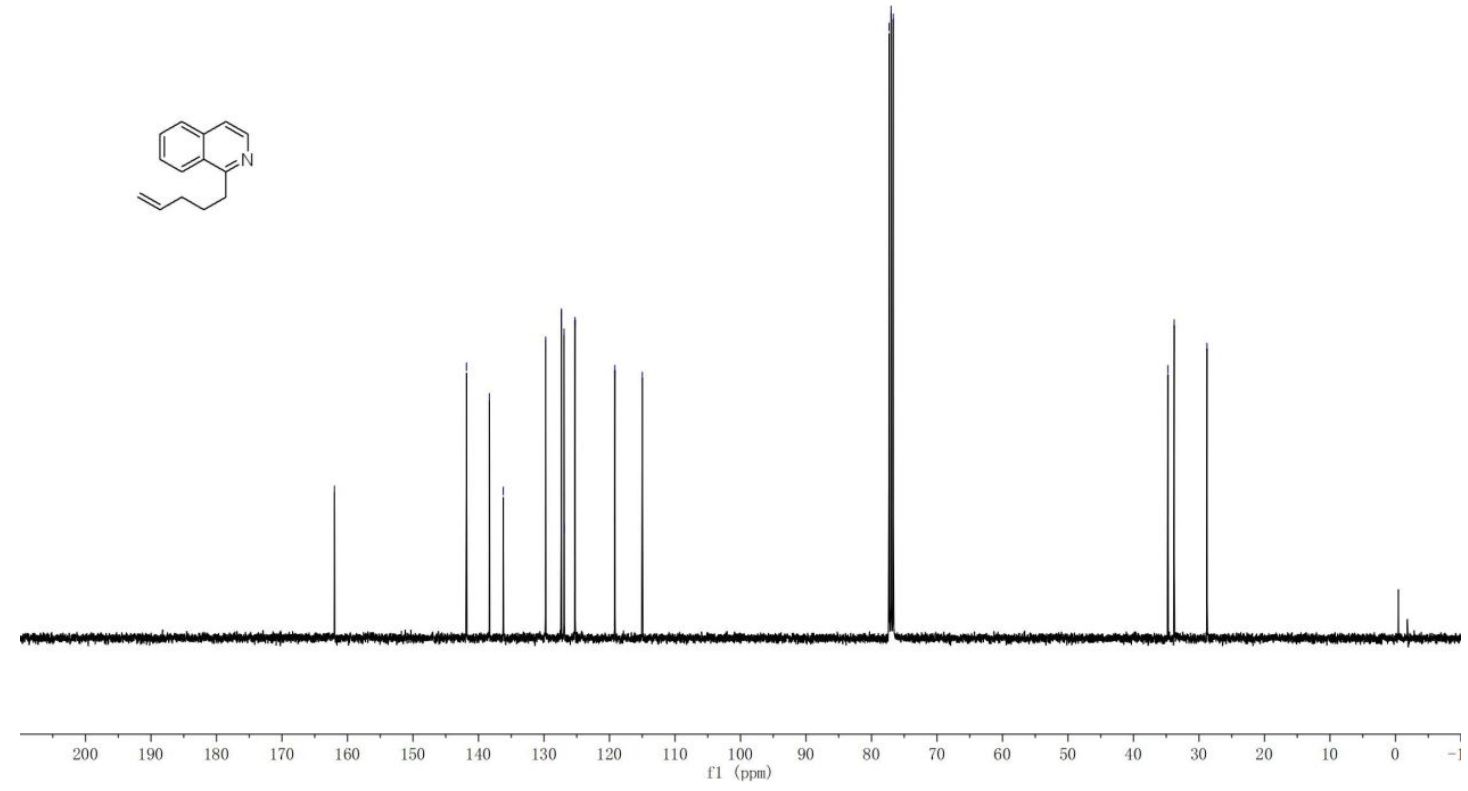

Figure S103. ${ }^{13} \mathrm{C}$ NMR Spectra of $\mathbf{6 p}$ 


\section{1-(hept-6-en-1-yl)isoquinoline (6q)}

9.
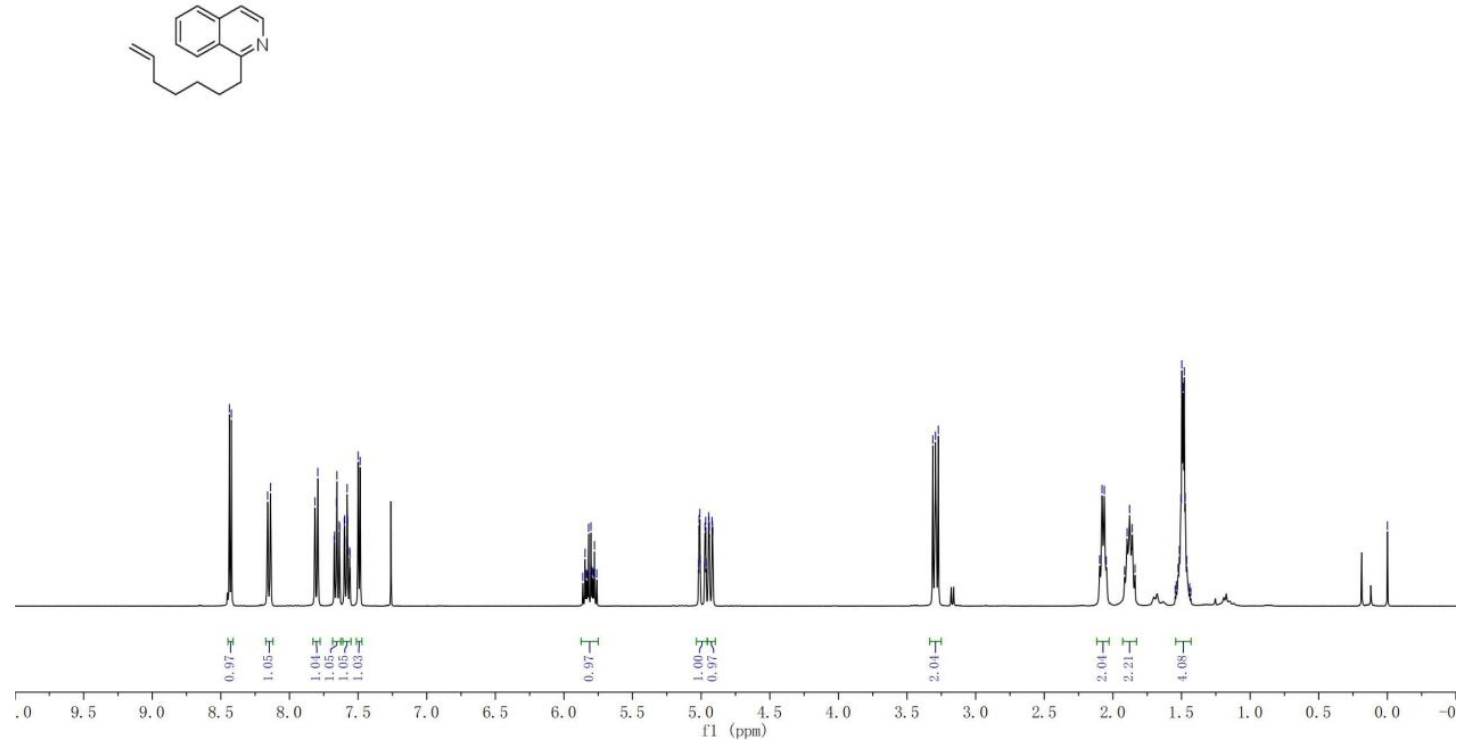

Figure S104. ${ }^{1} \mathrm{H}$ NMR Spectra of $\mathbf{6 q}$

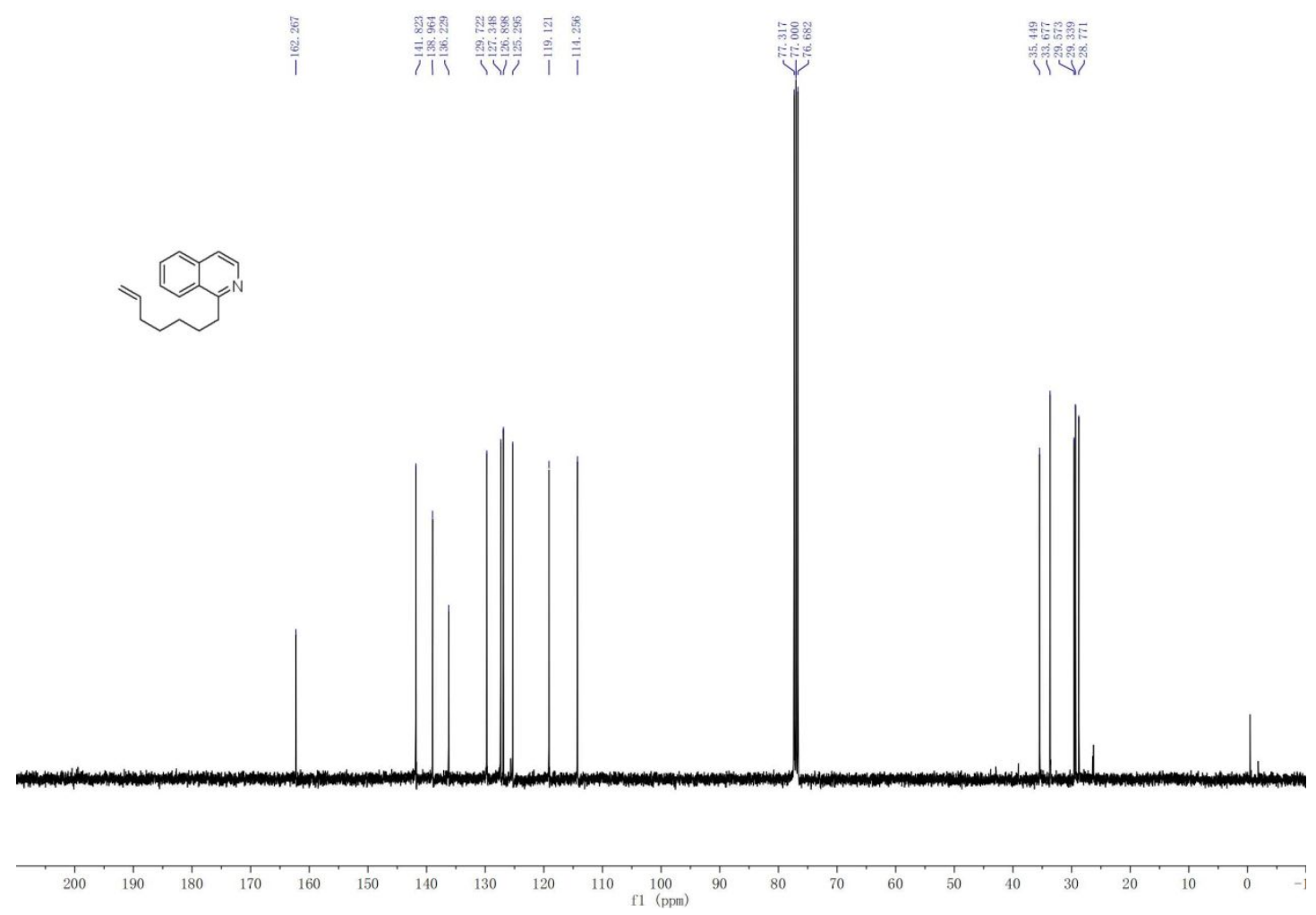

Figure S105. ${ }^{13} \mathrm{C}$ NMR Spectra of $\mathbf{6 q}$ 
ethyl 5-(isoquinolin-1-yl)pentanoate (6r)

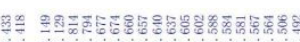

o
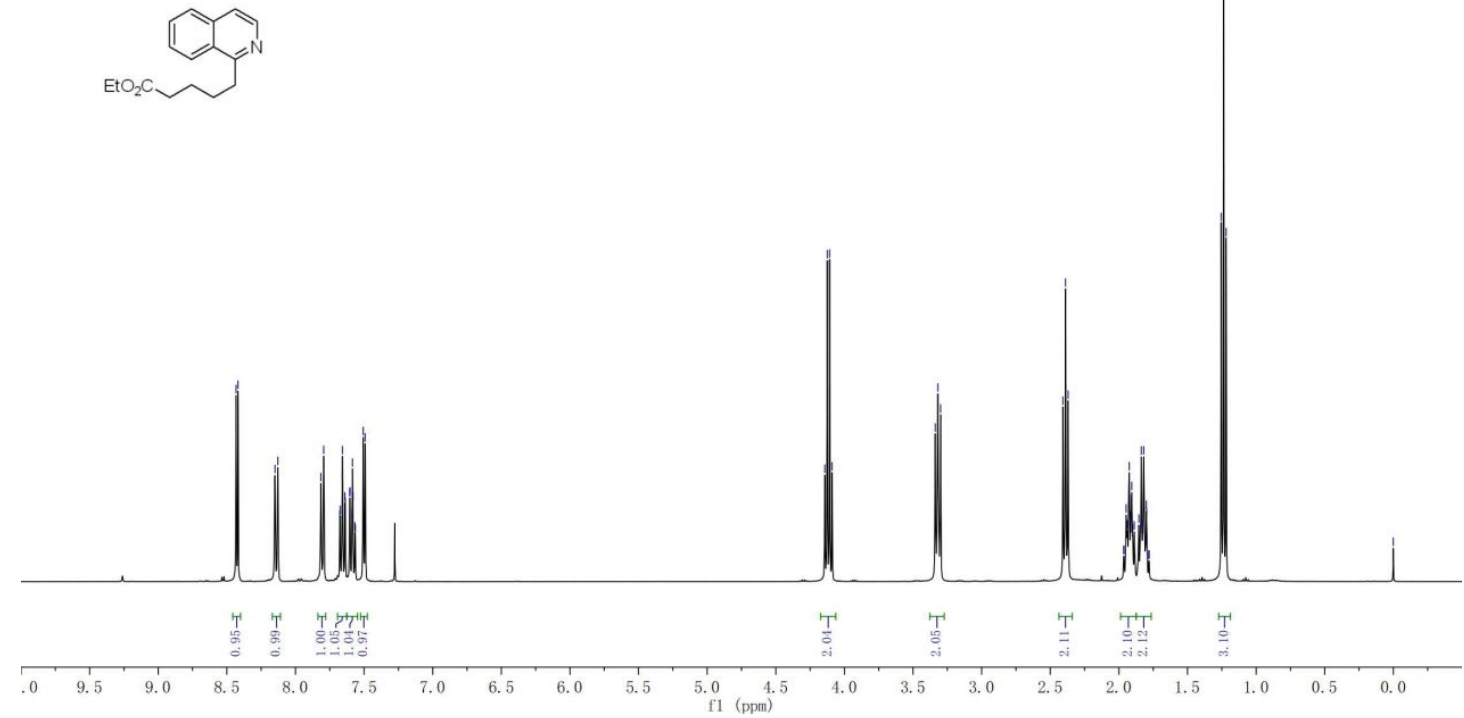

Figure S106. ${ }^{1} \mathrm{H}$ NMR Spectra of $\mathbf{6 r}$

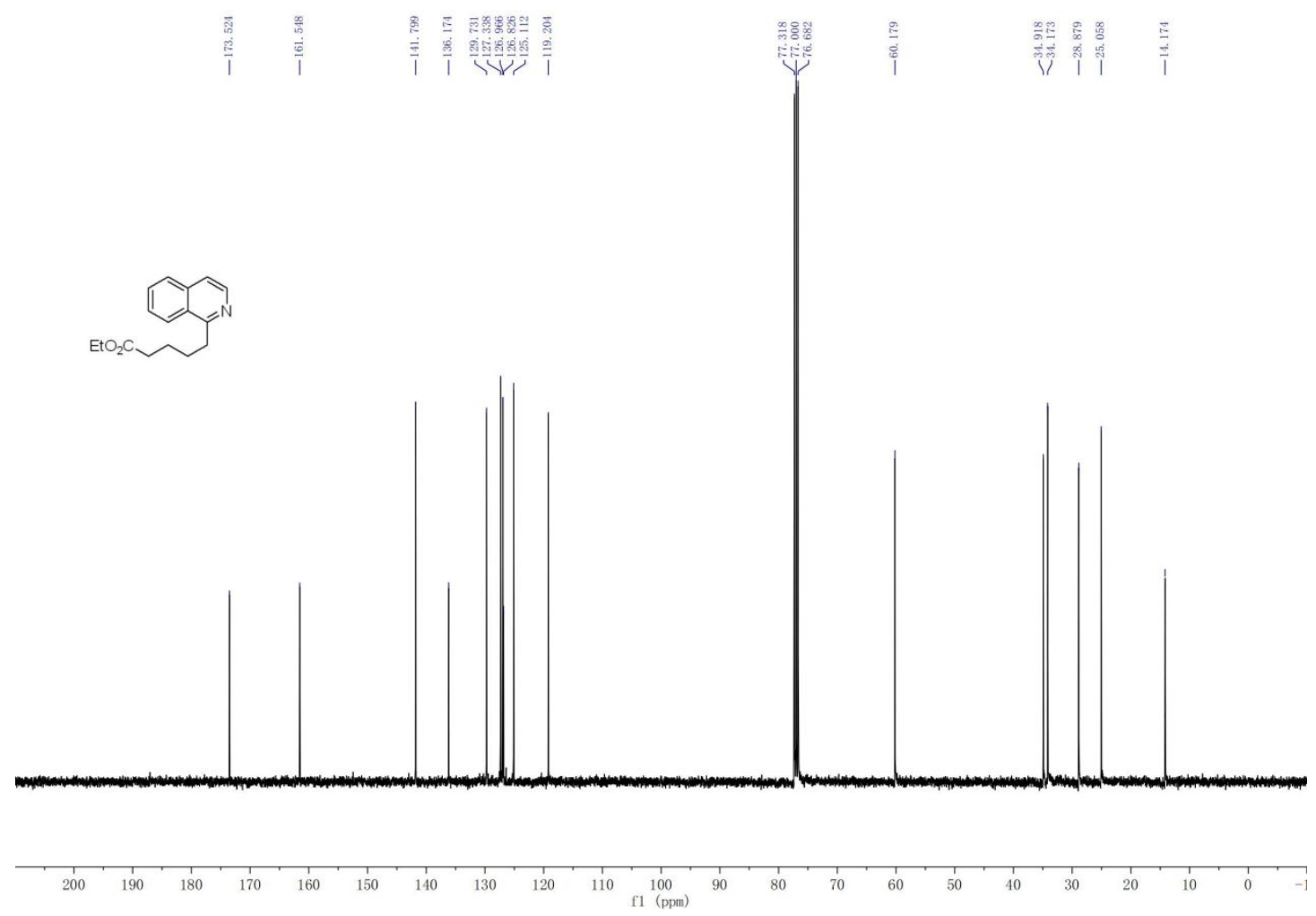

Figure S107. ${ }^{13} \mathrm{C}$ NMR Spectra of $\mathbf{6 r}$ 


\section{2-cyclohexyl-4-methylquinoline (6s)}

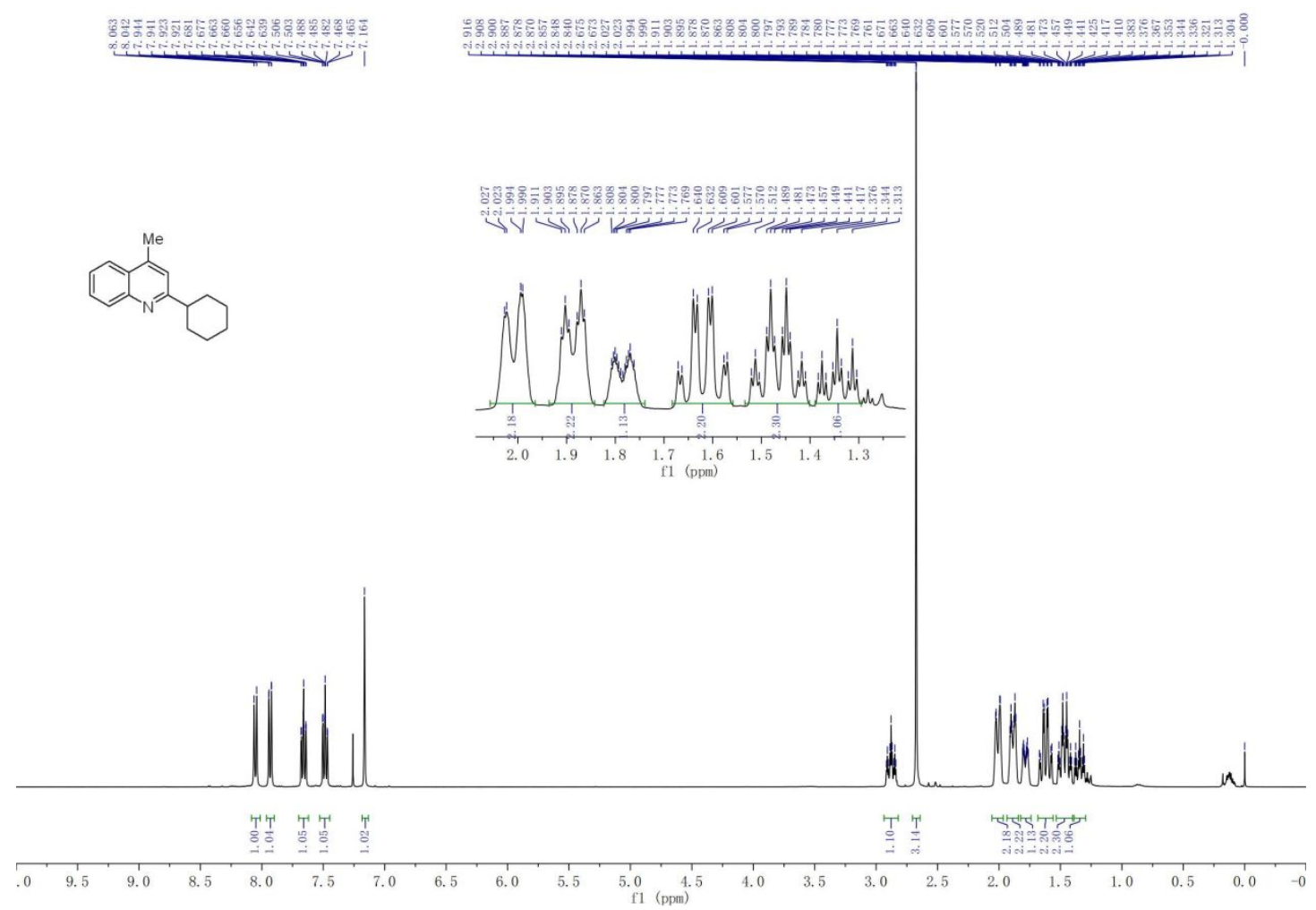

Figure S108. ${ }^{1} \mathrm{H}$ NMR Spectra of $\mathbf{6 s}$
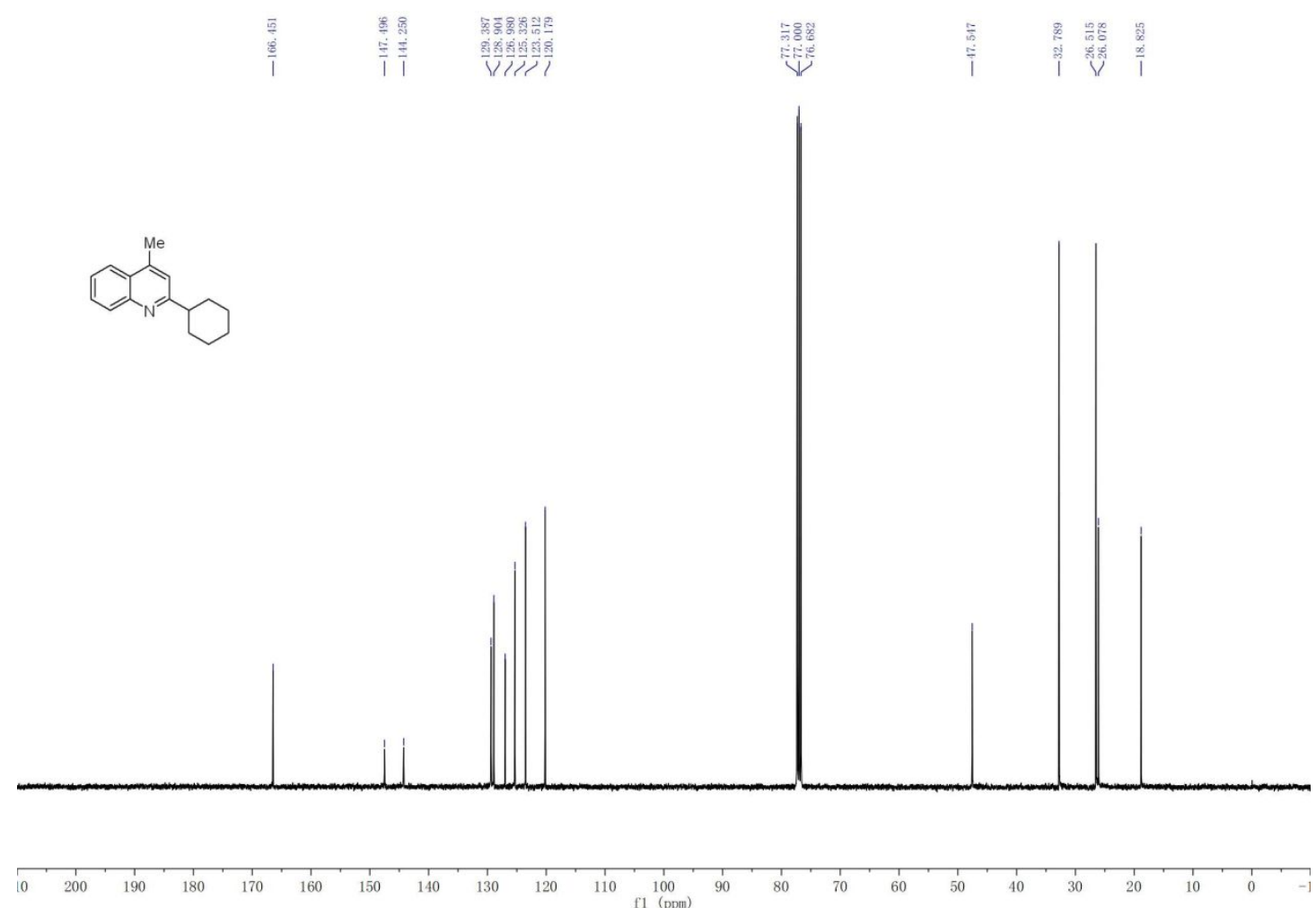

Figure S109. ${ }^{13} \mathrm{C}$ NMR Spectra of $\mathbf{6 s}$ 


\section{4-chloro-2-cyclohexylquinoline (6t)}
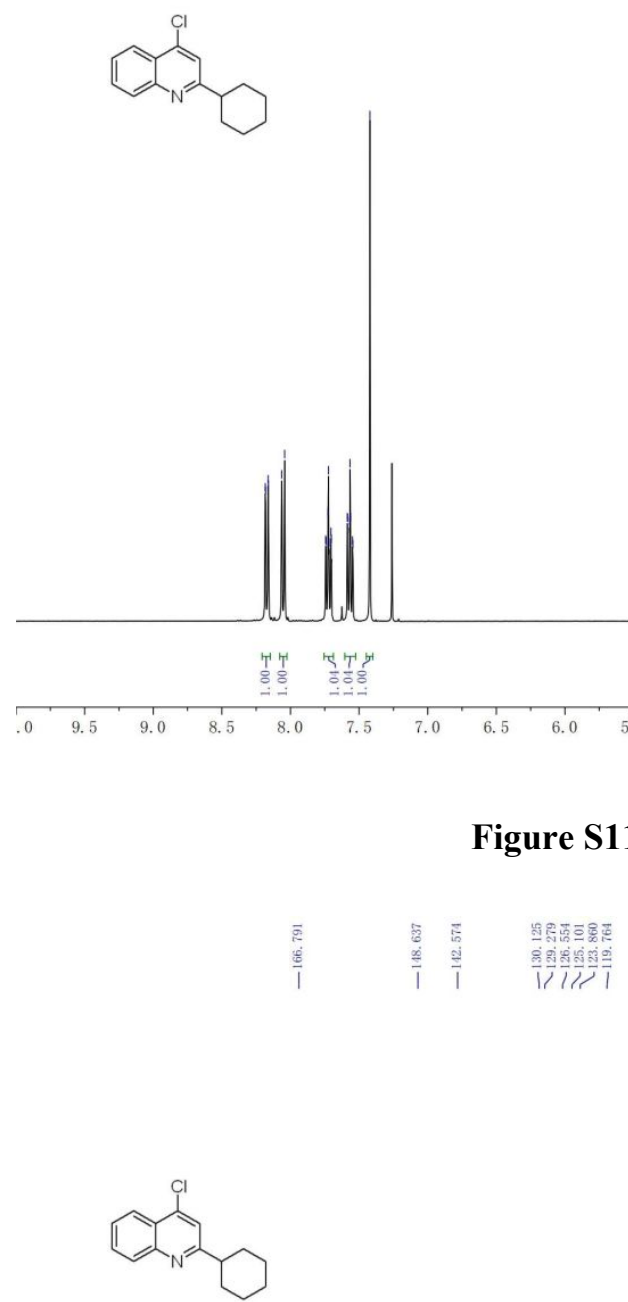

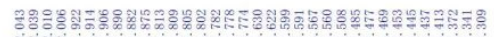

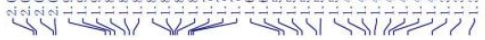
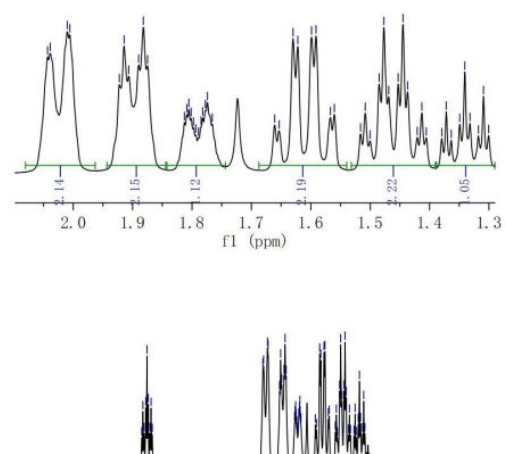

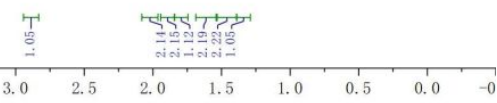

$($ pom $)$ 
4-cyclohexyl-2-methylquinoline (6u)

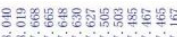

$\underbrace{0}$

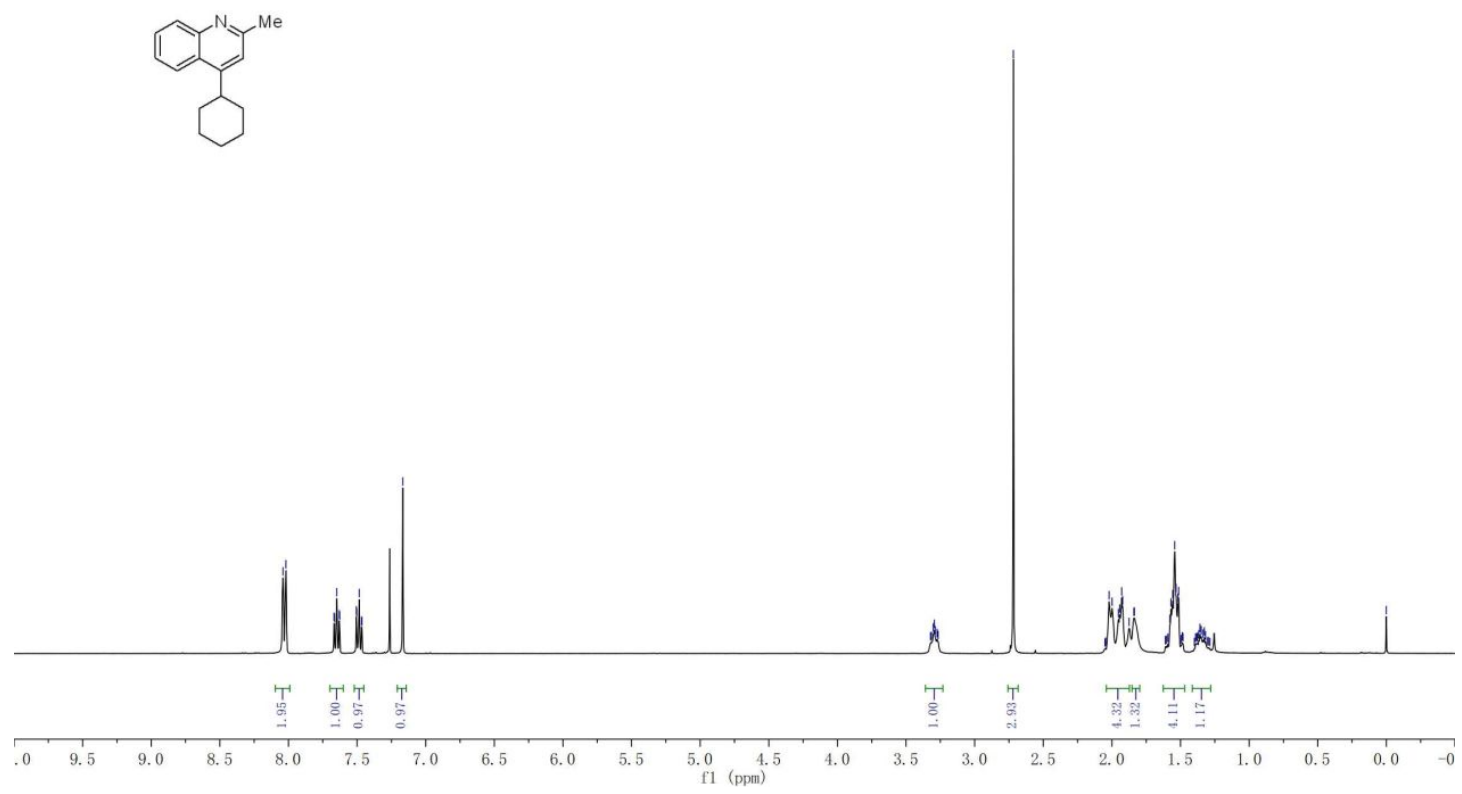

Figure S112. ${ }^{1} \mathrm{H}$ NMR Spectra of $6 u$

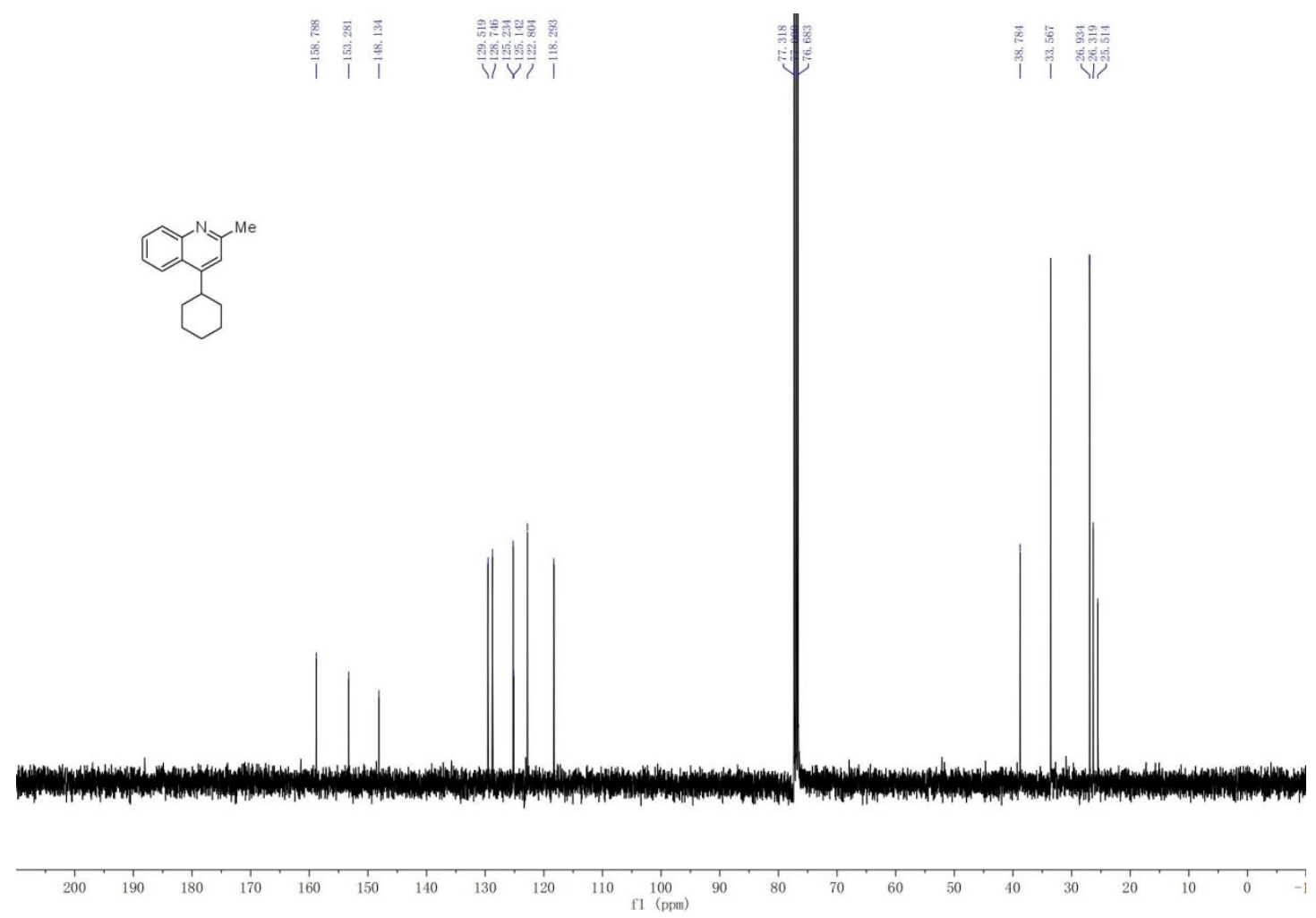

Figure S113. ${ }^{13} \mathrm{C}$ NMR Spectra of $\mathbf{6 u}$ 
5-bromo-1-cyclohexylisoquinoline (6v)
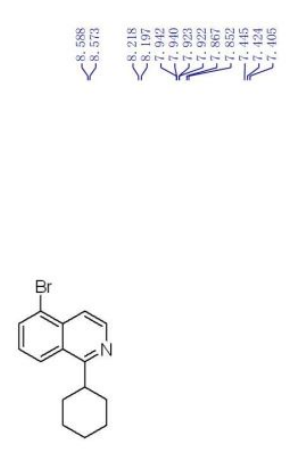

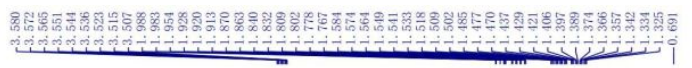

\&:

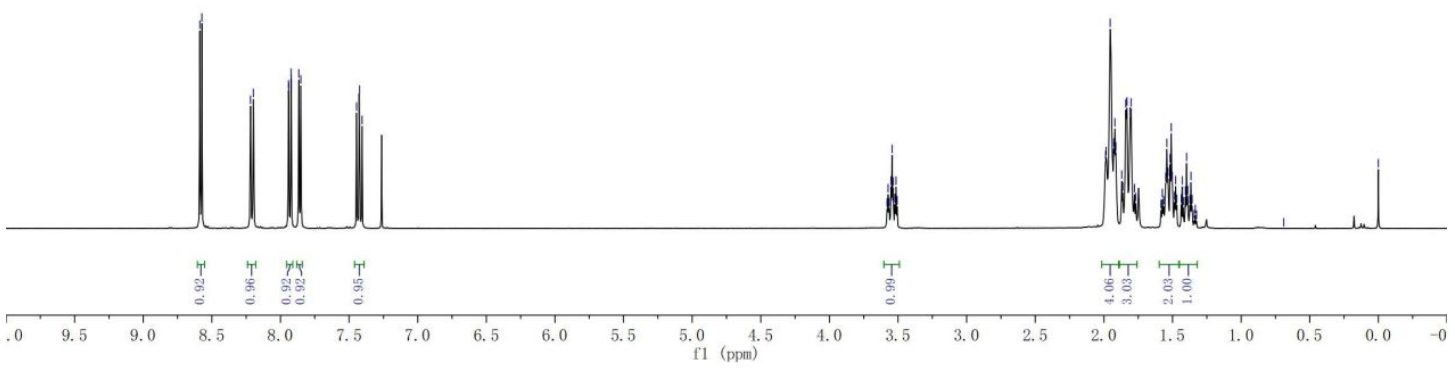

Figure S114. ${ }^{1} \mathrm{H}$ NMR Spectra of $\mathbf{6 v}$

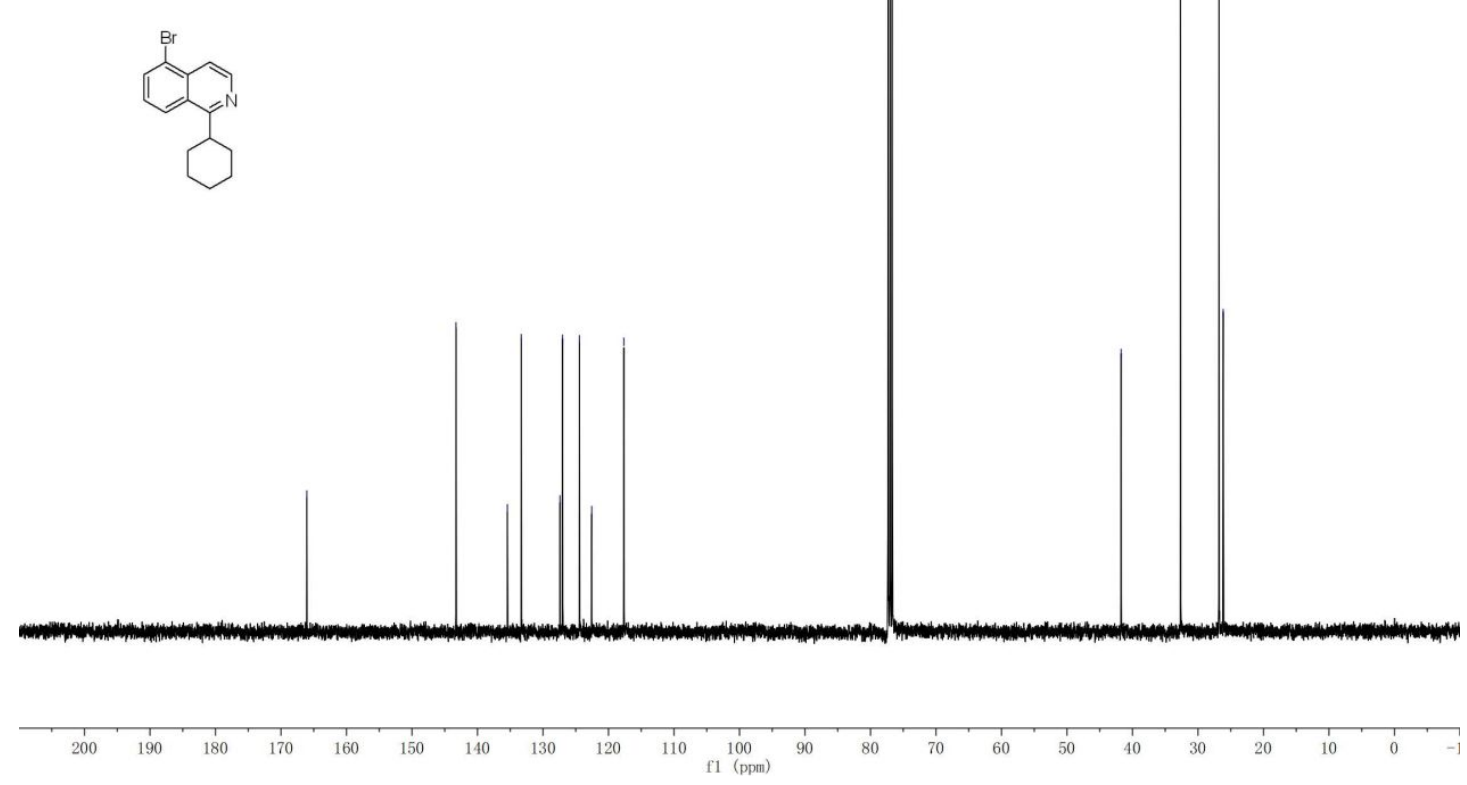

Figure S115. ${ }^{13} \mathrm{C}$ NMR Spectra of $\mathbf{6 v}$

S66 


\section{1-cyclohexyl-6-methylisoquinoline (6w)}

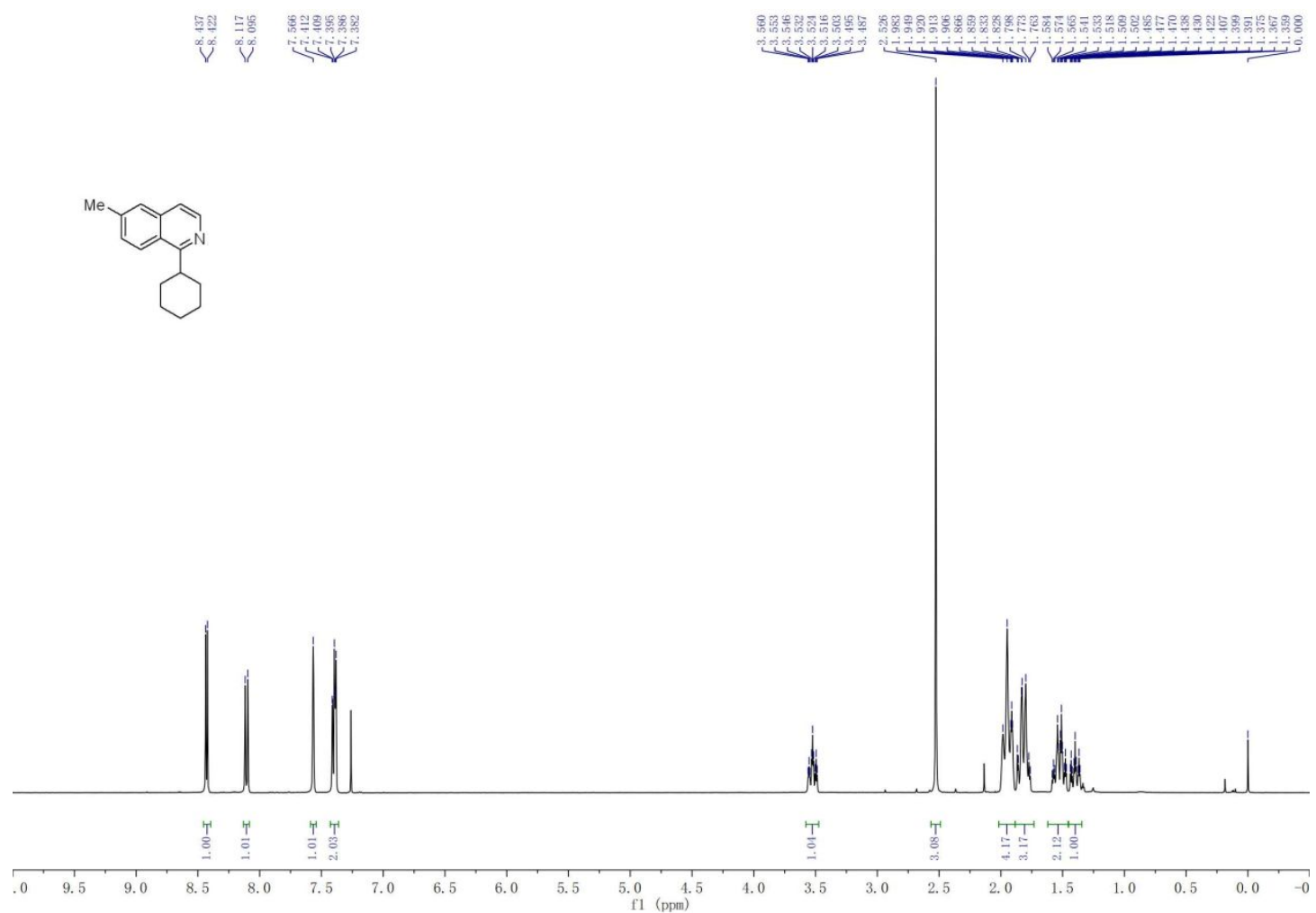

Figure S116. ${ }^{1} \mathrm{H}$ NMR Spectra of $\mathbf{6 w}$

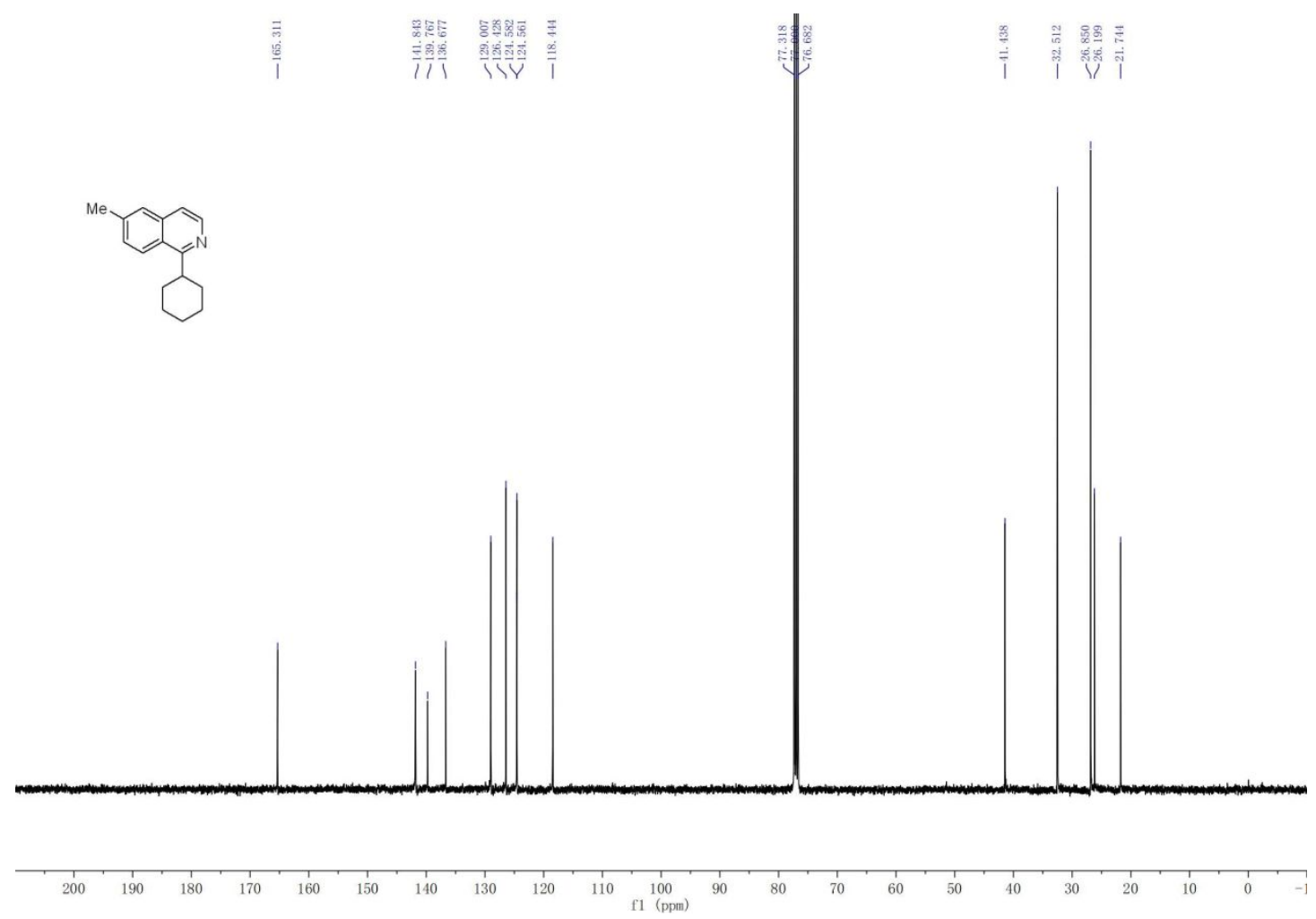

Figure S117. ${ }^{13} \mathrm{C}$ NMR Spectra of $\mathbf{6 w}$ 


\section{2-cyclohexylquinoxaline (6x)}
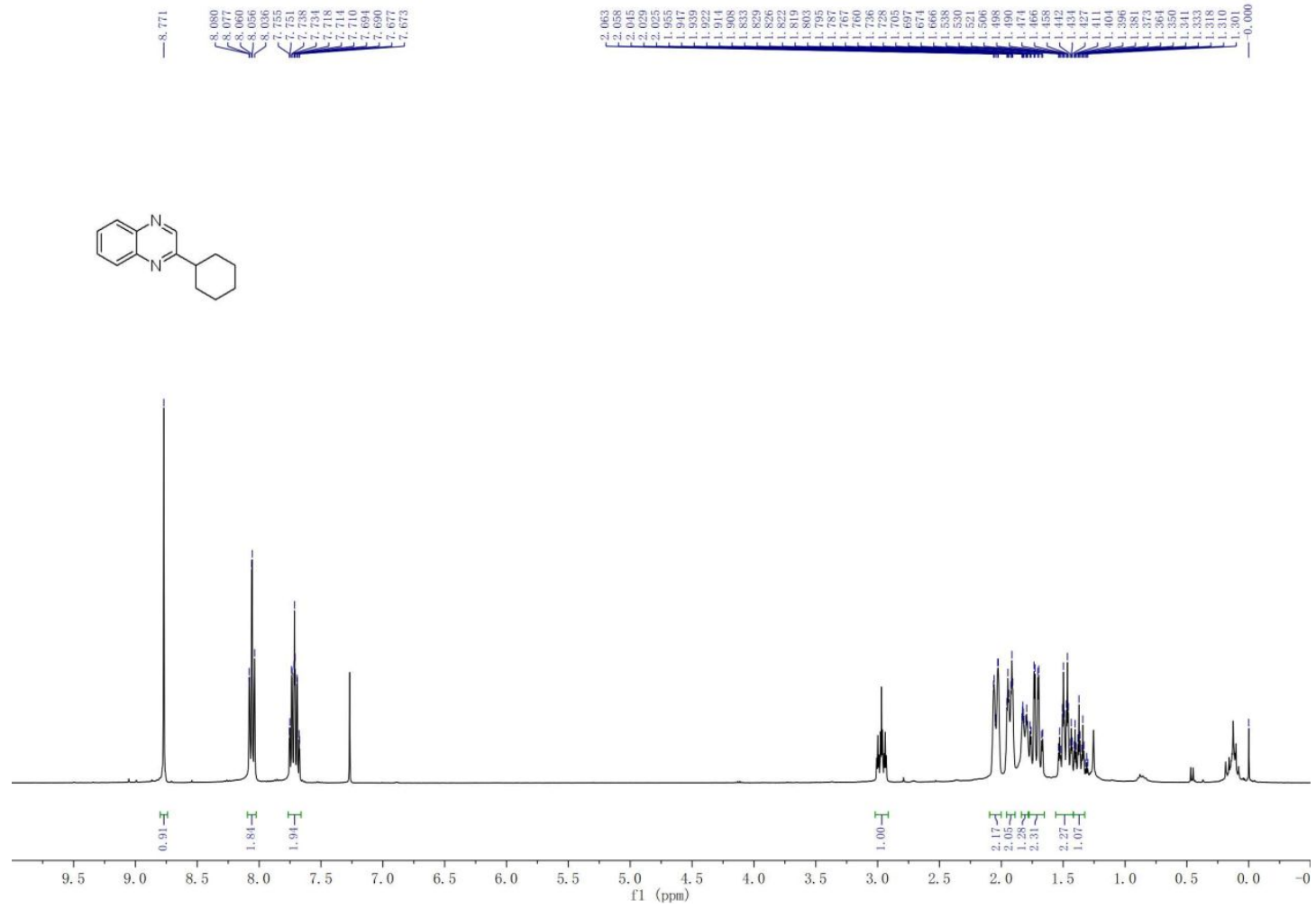

Figure S118. ${ }^{1} \mathrm{H}$ NMR Spectra of $\mathbf{6 x}$

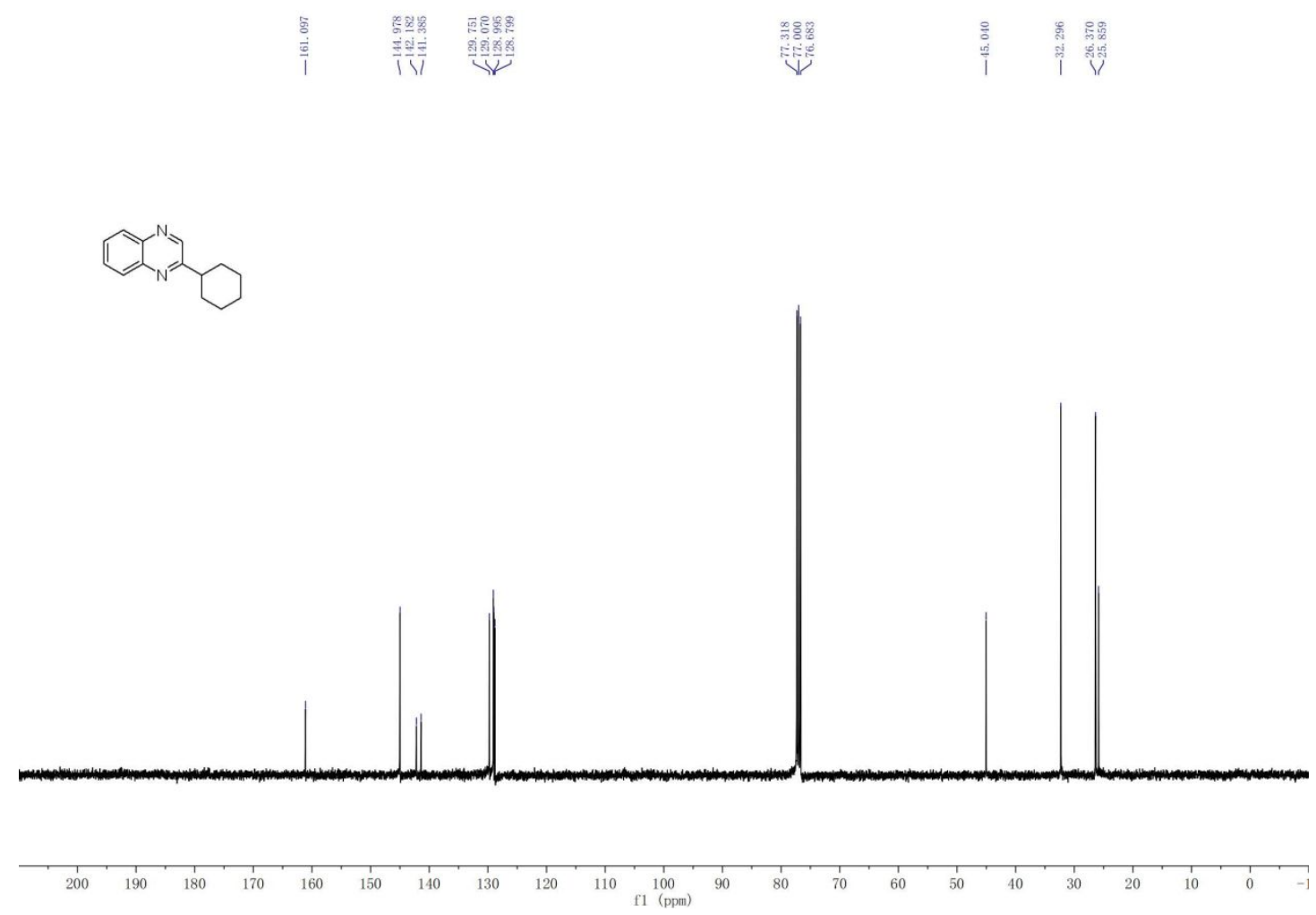

Figure S119. ${ }^{13} \mathrm{C}$ NMR Spectra of $\mathbf{6 x}$ 
2-chloro-3-cyclohexylquinoxaline (6y)

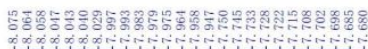

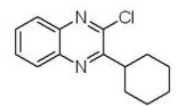

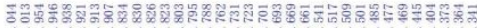

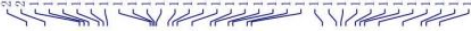
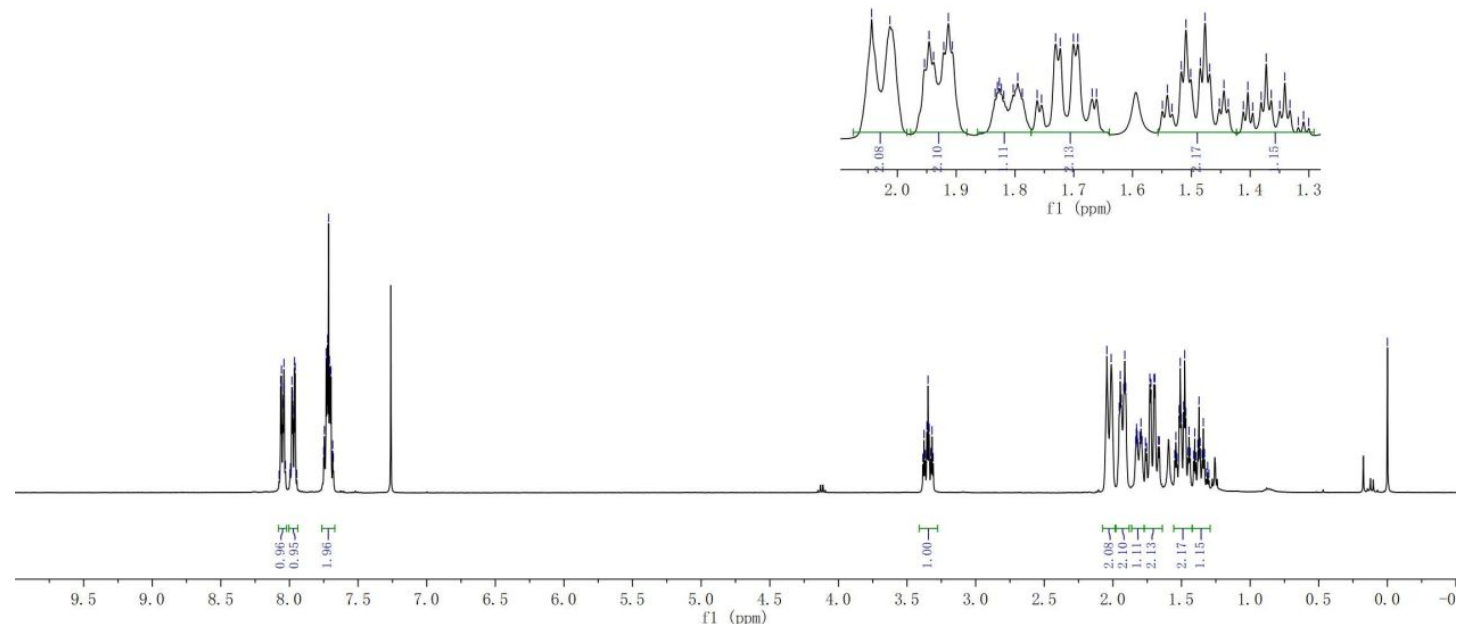

Figure S120. ${ }^{1} \mathrm{H}$ NMR Spectra of $\mathbf{6 y}$

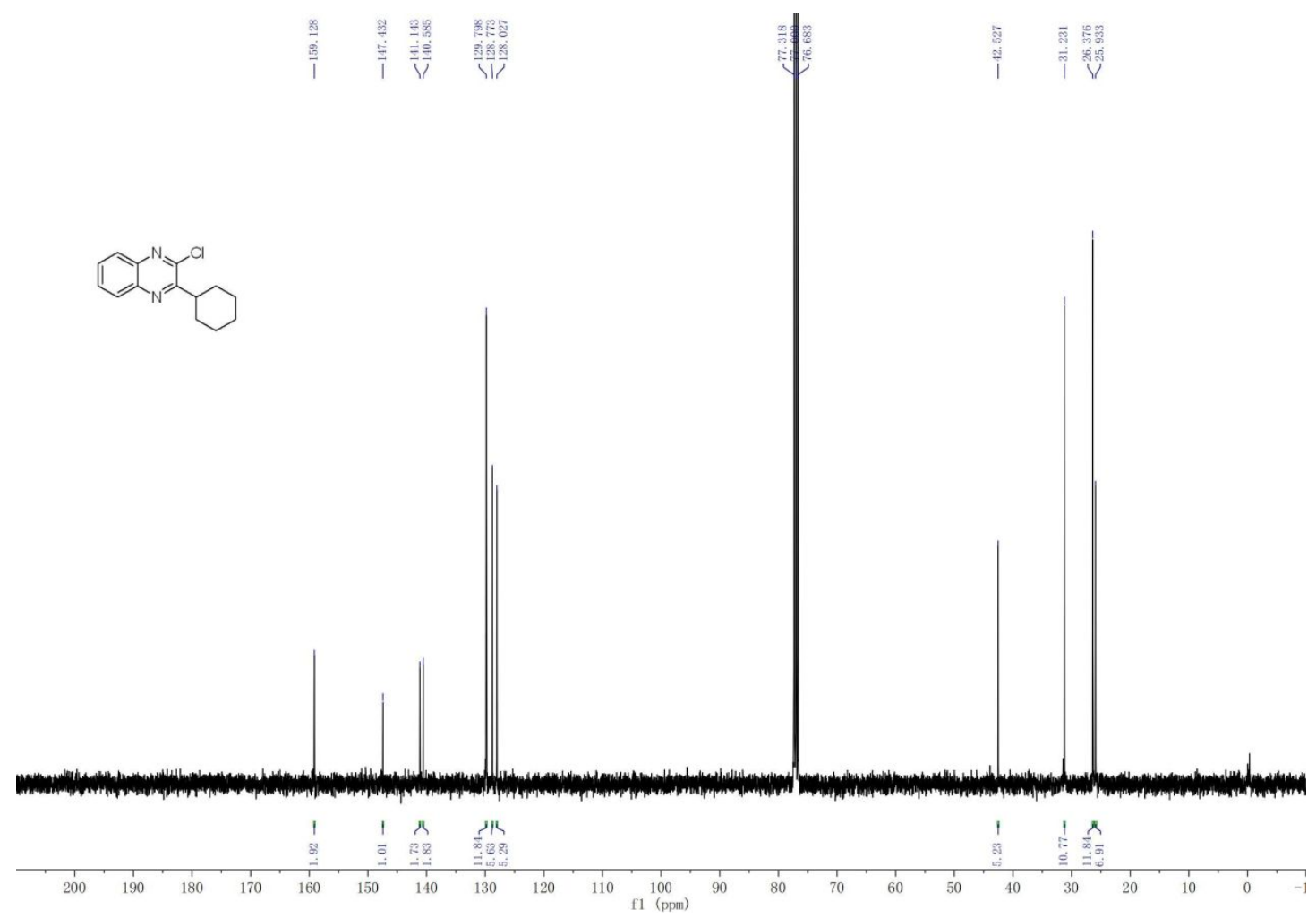

Figure S121. ${ }^{13} \mathrm{C}$ NMR Spectra of $\mathbf{6 y}$ 
2-cyclohexylbenzo[d] thiazole (6z)

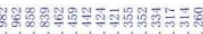

iv
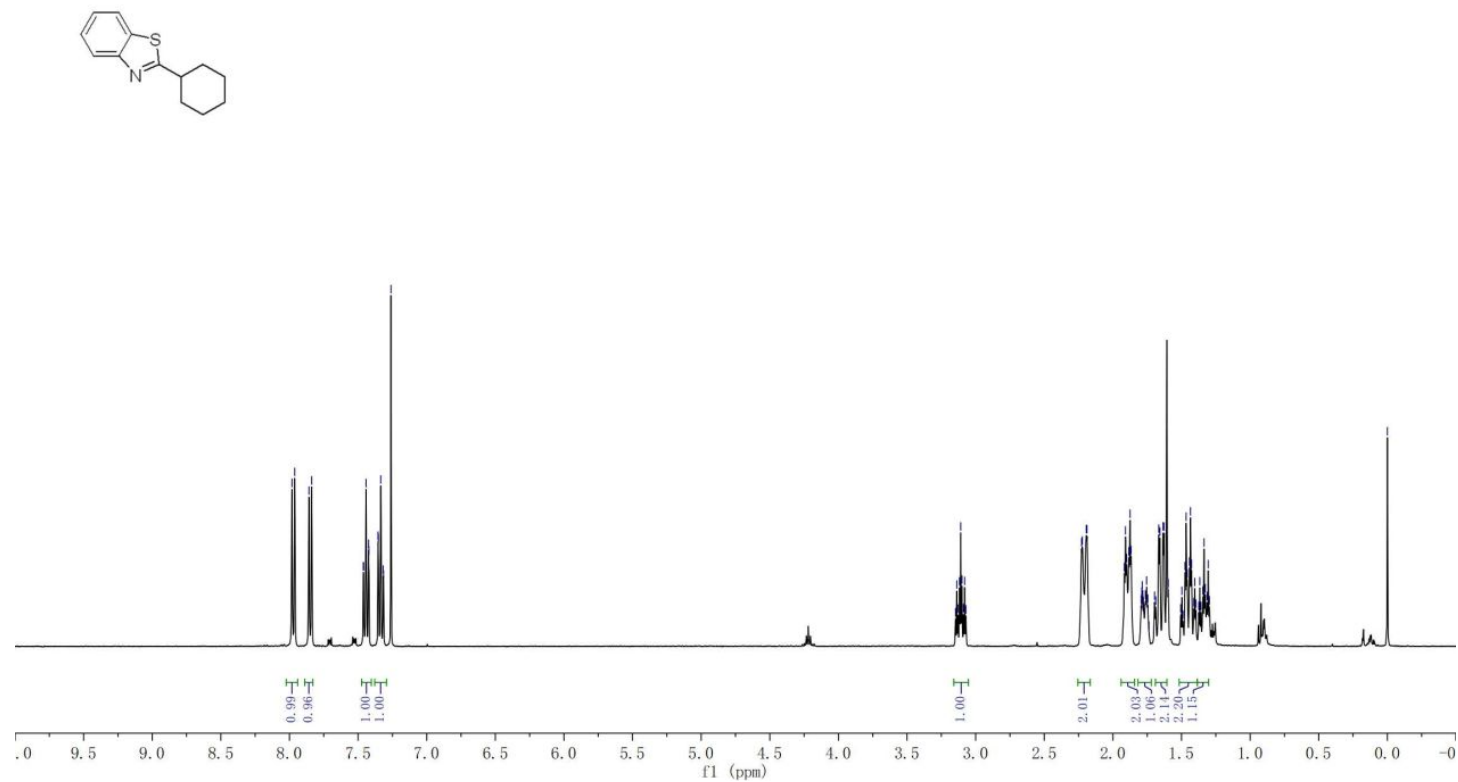

Figure S122. ${ }^{1} \mathrm{H}$ NMR Spectra of $\mathbf{6 z}$

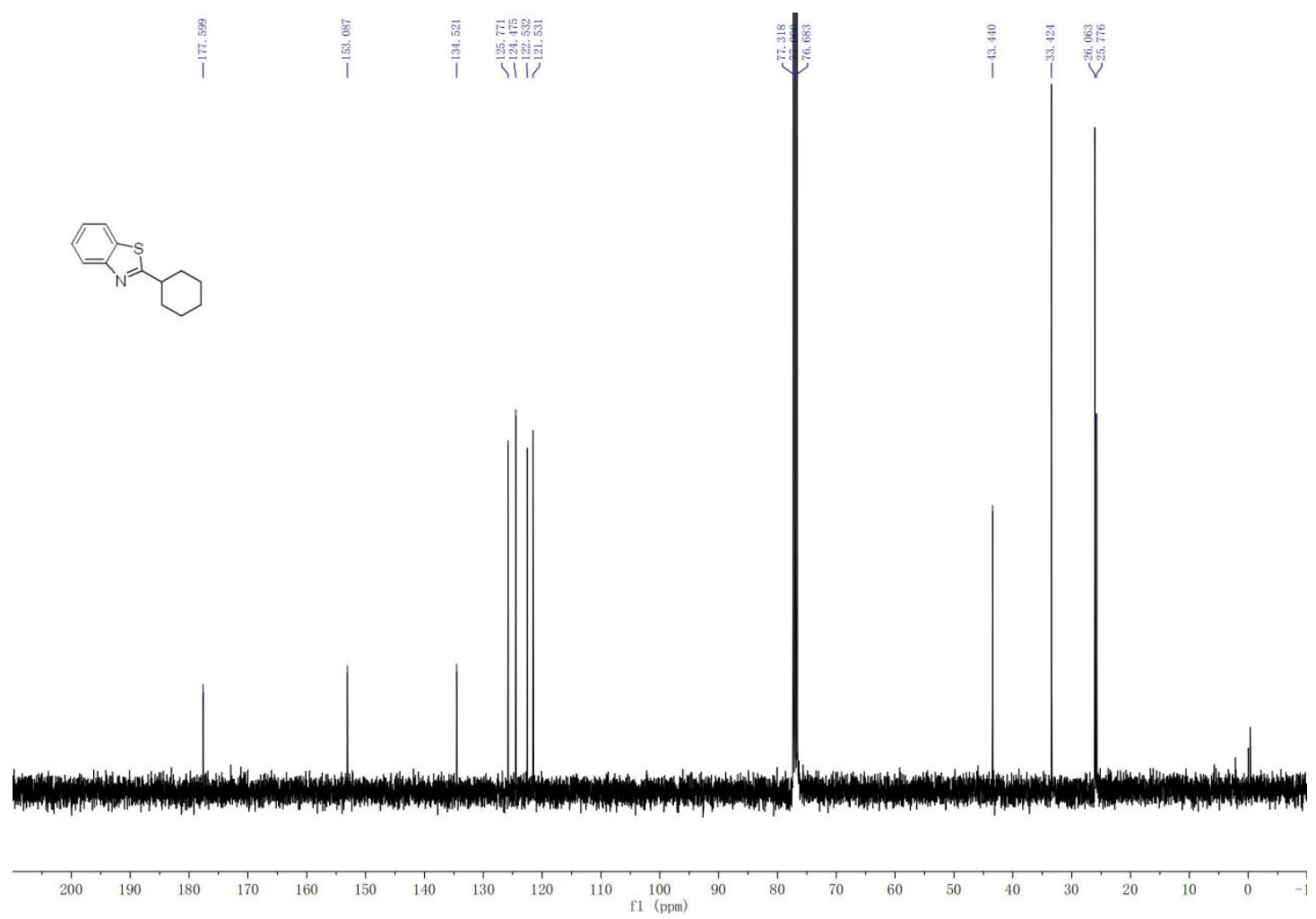

Figure S123. ${ }^{13} \mathrm{C}$ NMR Spectra of $\mathbf{6 z}$ 


\section{5-cyclohexyl-2,3-diphenylpyrido[3,4-b]pyrazine (6aa)}

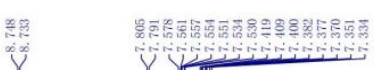

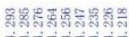

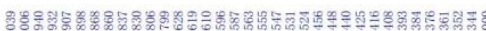
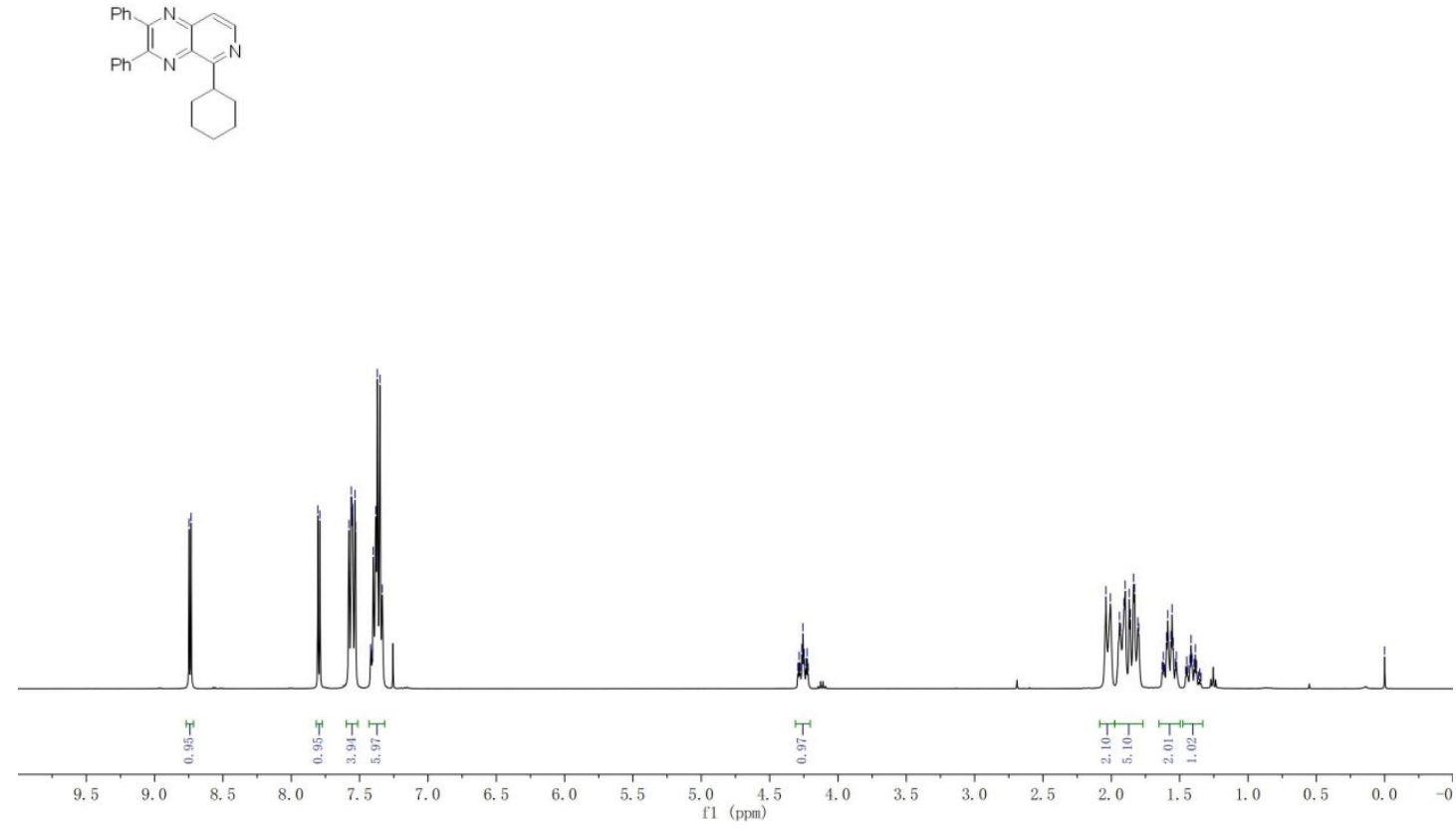

Figure S124. ${ }^{1} \mathrm{H}$ NMR Spectra of $6 \mathbf{a a}$
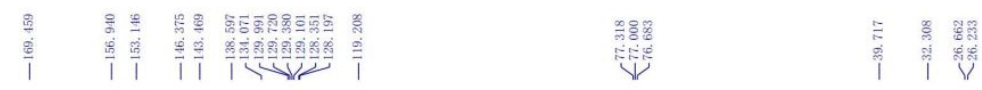

(n)
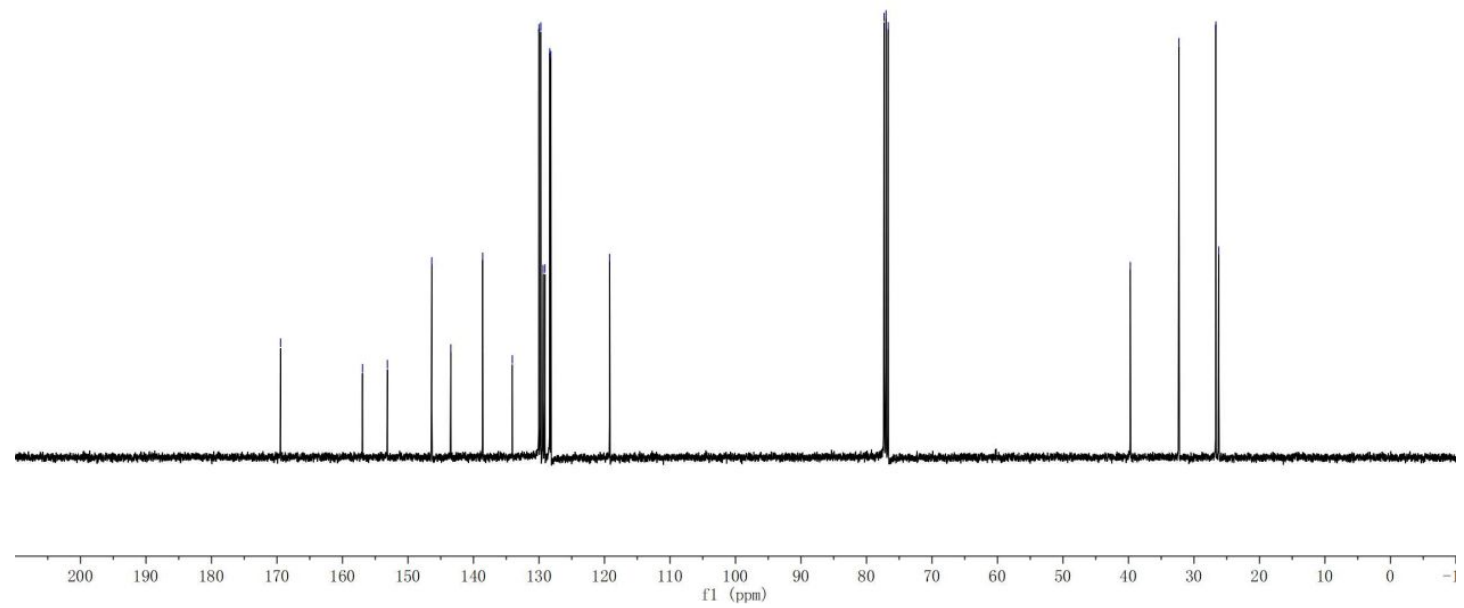

Figure S125. ${ }^{13} \mathrm{C}$ NMR Spectra of $6 \mathbf{a a}$ 
6-chloro-7-cyclohexylimidazo[1,2-b]pyridazine (6ab)

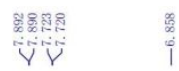

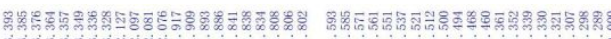

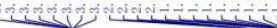
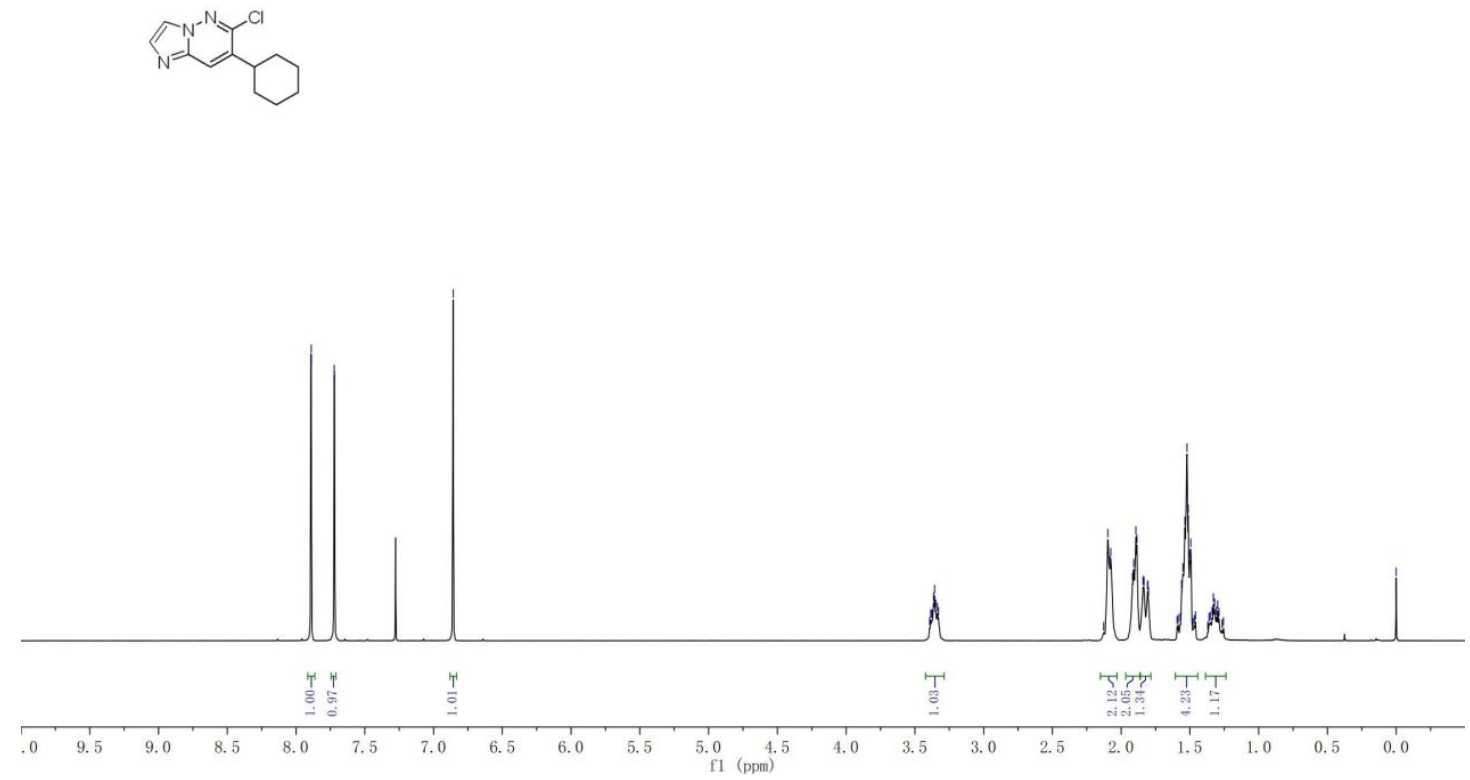

Figure S126. ${ }^{1} \mathrm{H}$ NMR Spectra of $\mathbf{6 a b}$
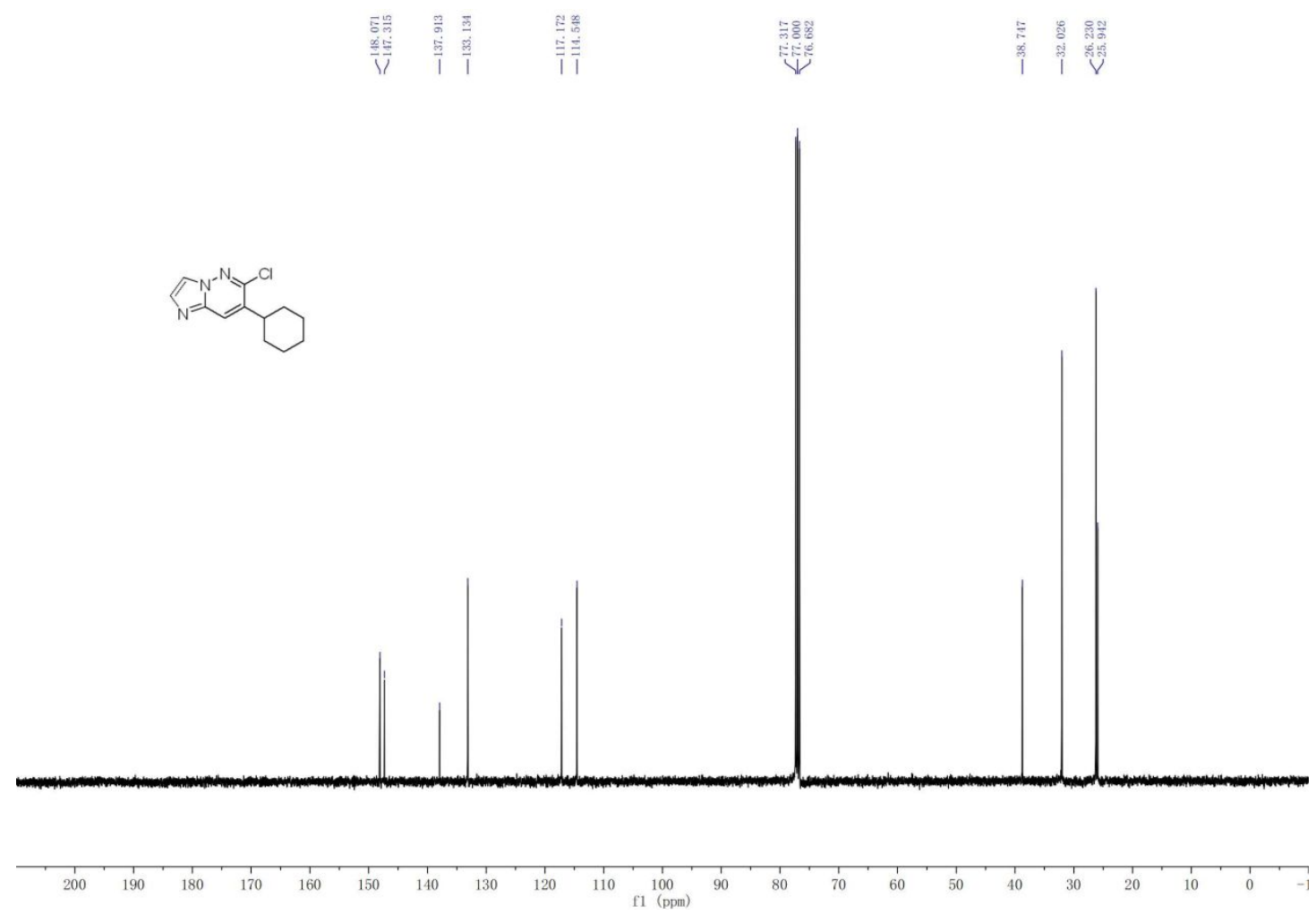

Figure S127. ${ }^{13} \mathrm{C}$ NMR Spectra of $\mathbf{6 a b}$ 
2-cyclohexylisonicotinonitrile (fac)

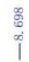

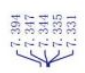

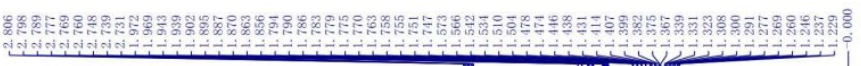
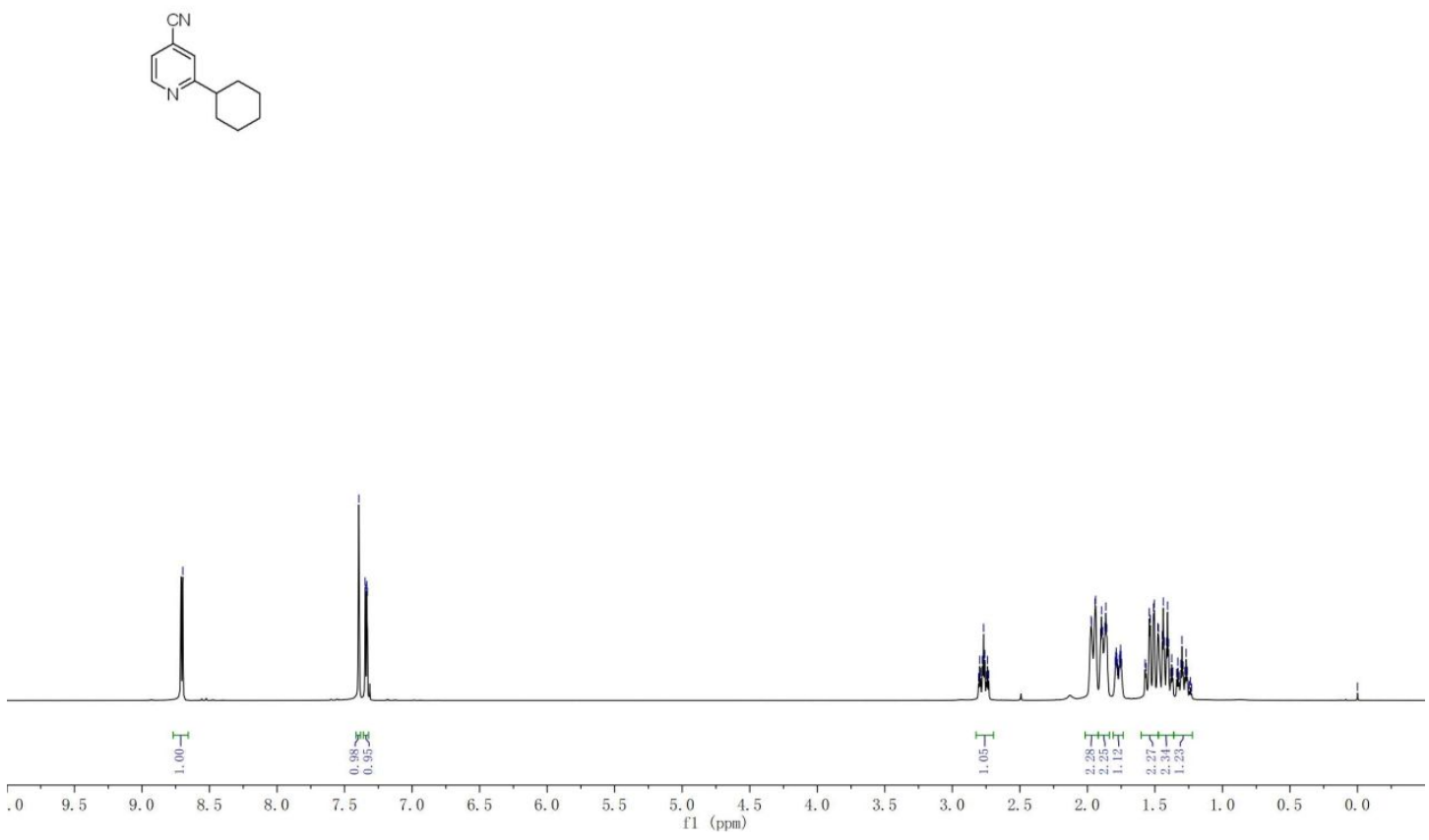

Figure S128. ${ }^{1} \mathrm{H}$ NMR Spectra of 6 ac
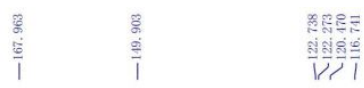

"
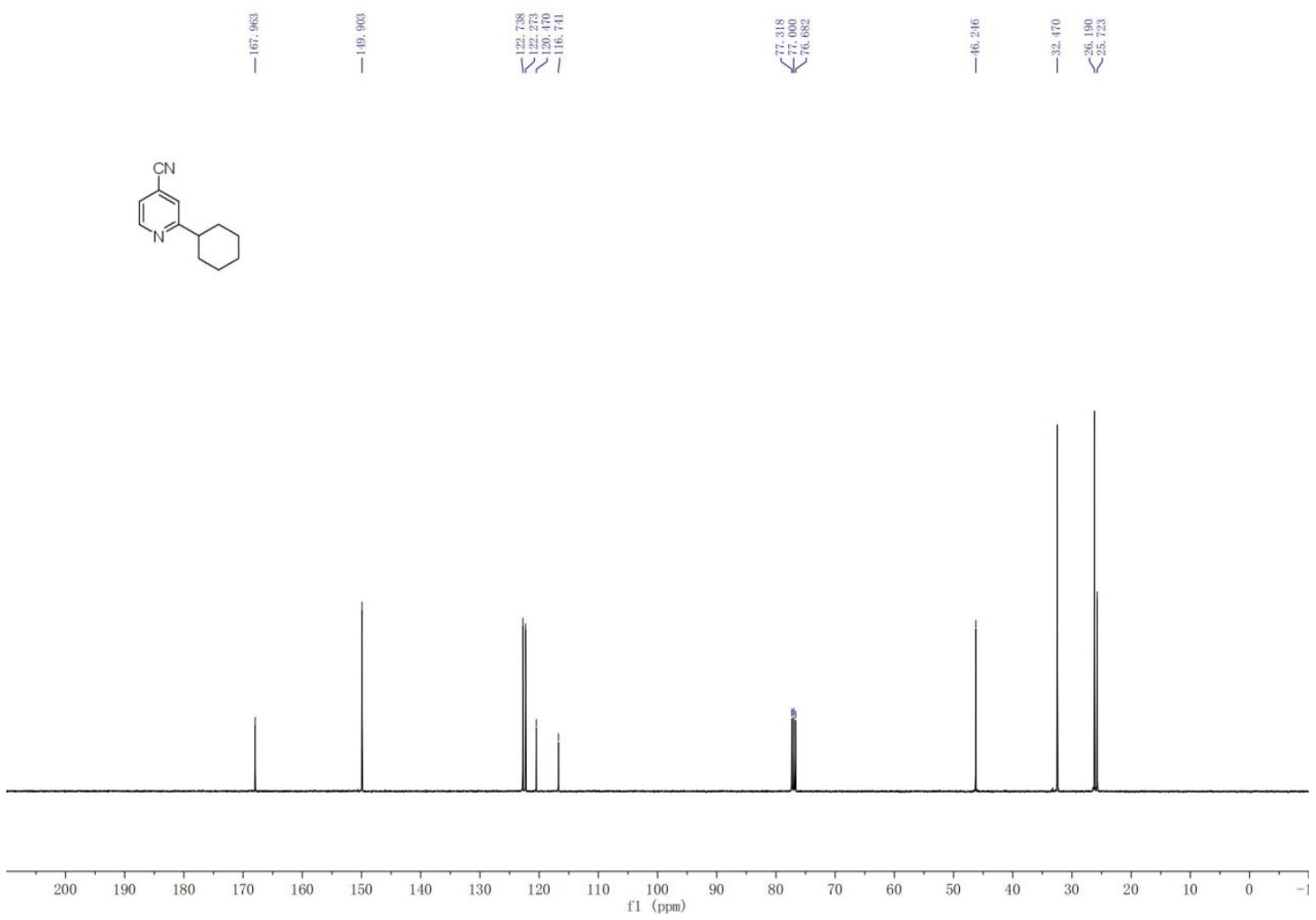

Figure S129. ${ }^{13} \mathrm{C}$ NMR Spectra of $6 \mathbf{a c}$

$\mathrm{S} 73$ 


\section{4-cyclohexylquinazoline (6ad)}

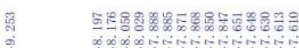

ن

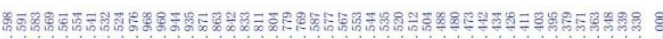

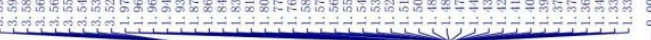<smiles></smiles>

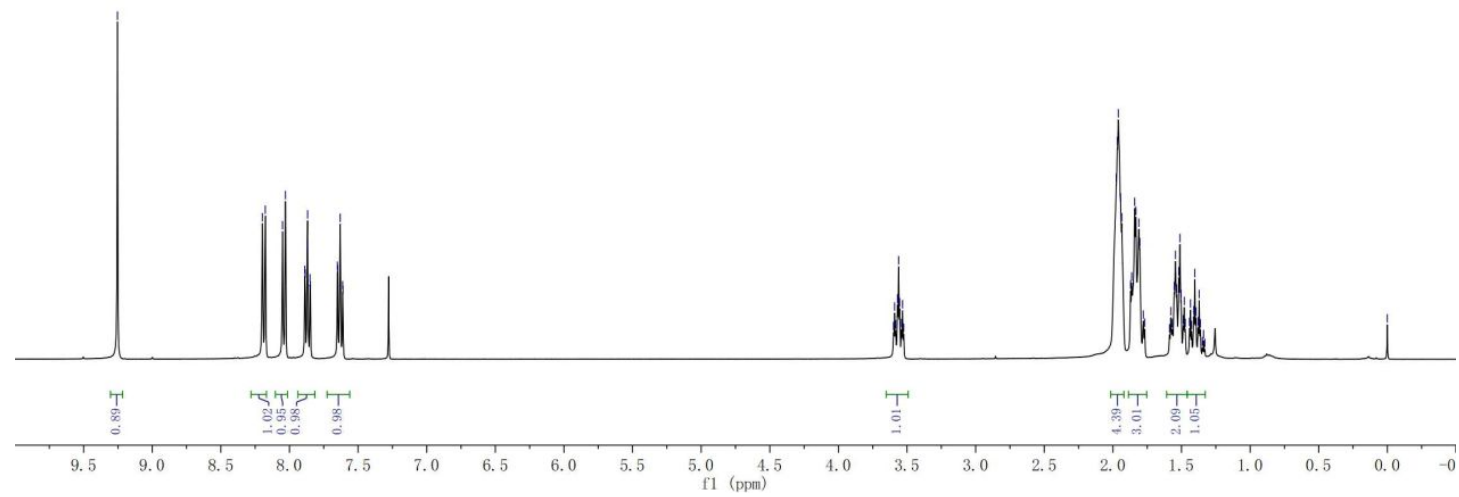

Figure S130. ${ }^{1} \mathrm{H}$ NMR Spectra of $\mathbf{6 a d}$

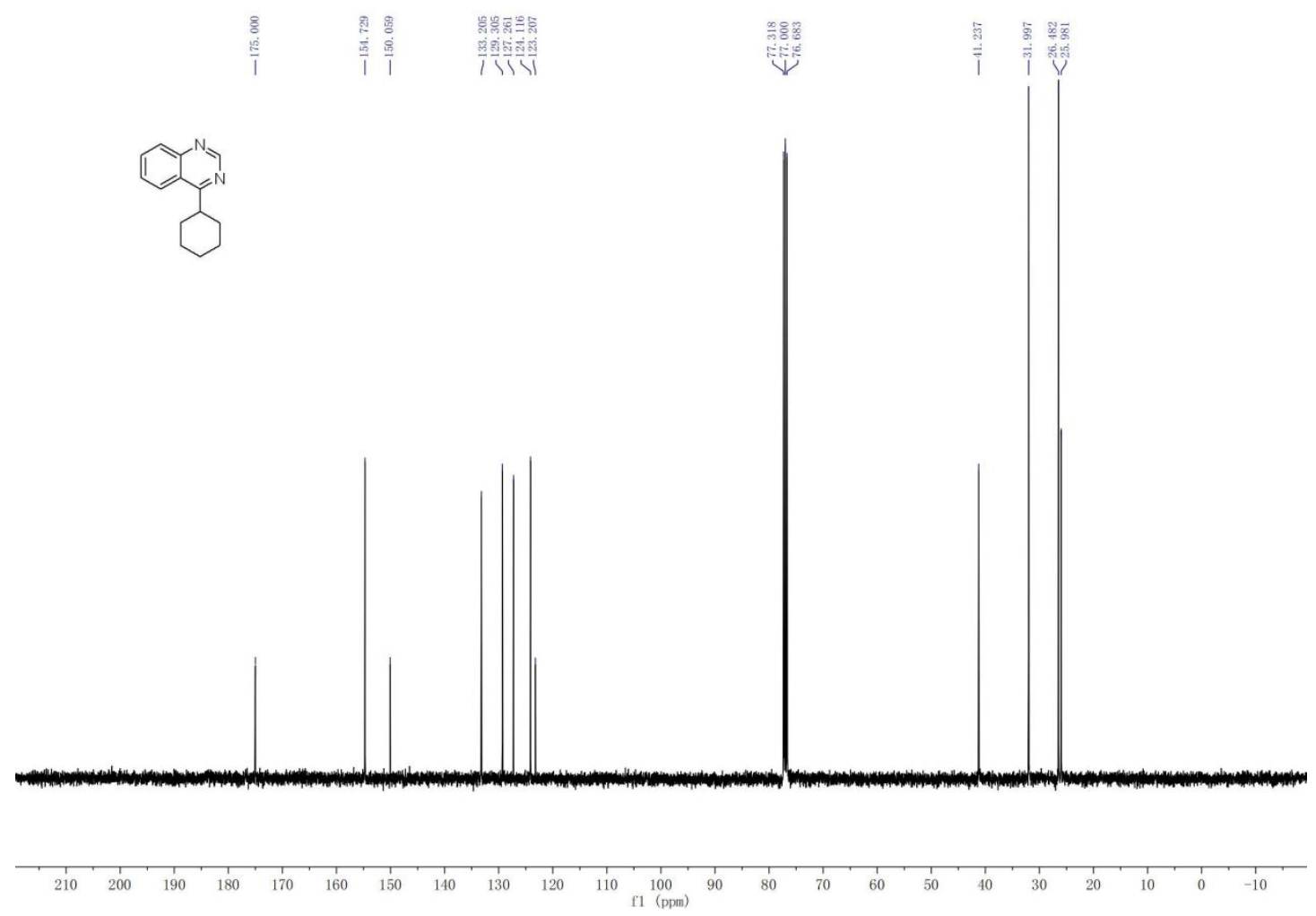

Figure S131. ${ }^{13} \mathrm{C}$ NMR Spectra of $\mathbf{6 a d}$ 


\section{2,4-dicyclohexylquinazoline (6ad')}

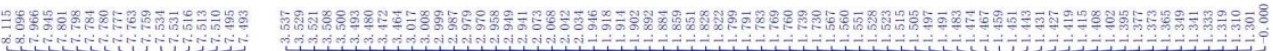<smiles>c1ccc2c(C3CCCCC3)nc(C3CCCCC3)nc2c1</smiles>

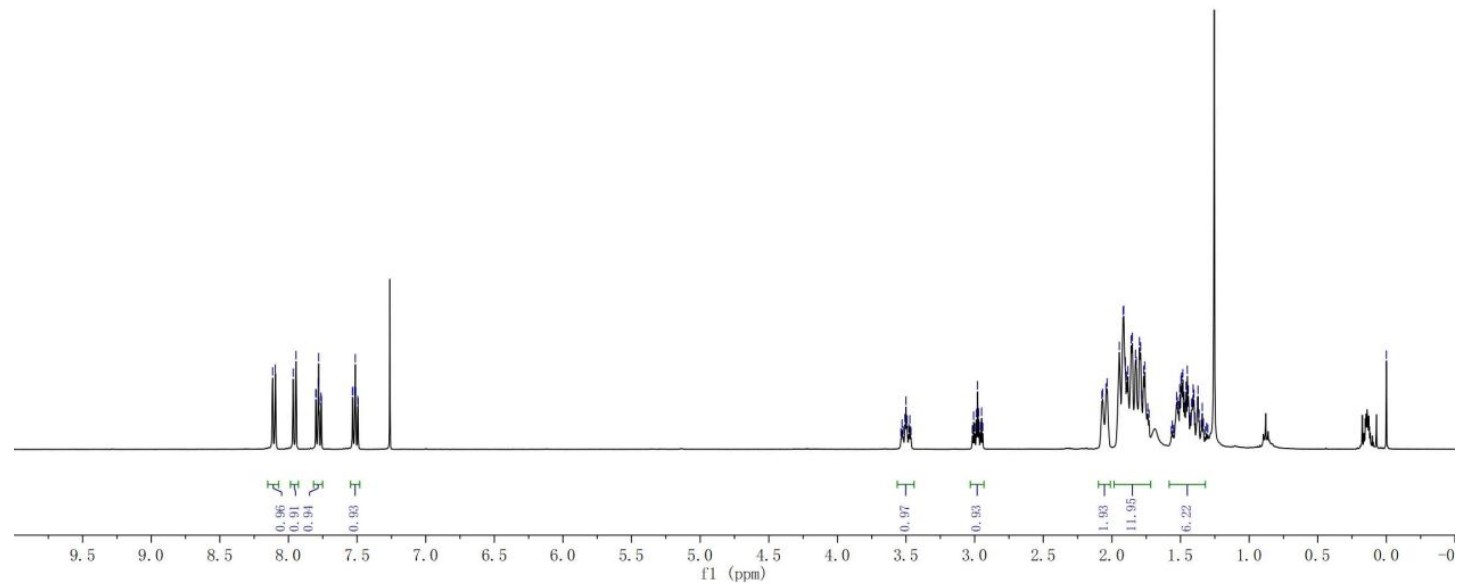

Figure S132. 'H NMR Spectra of 6ad'

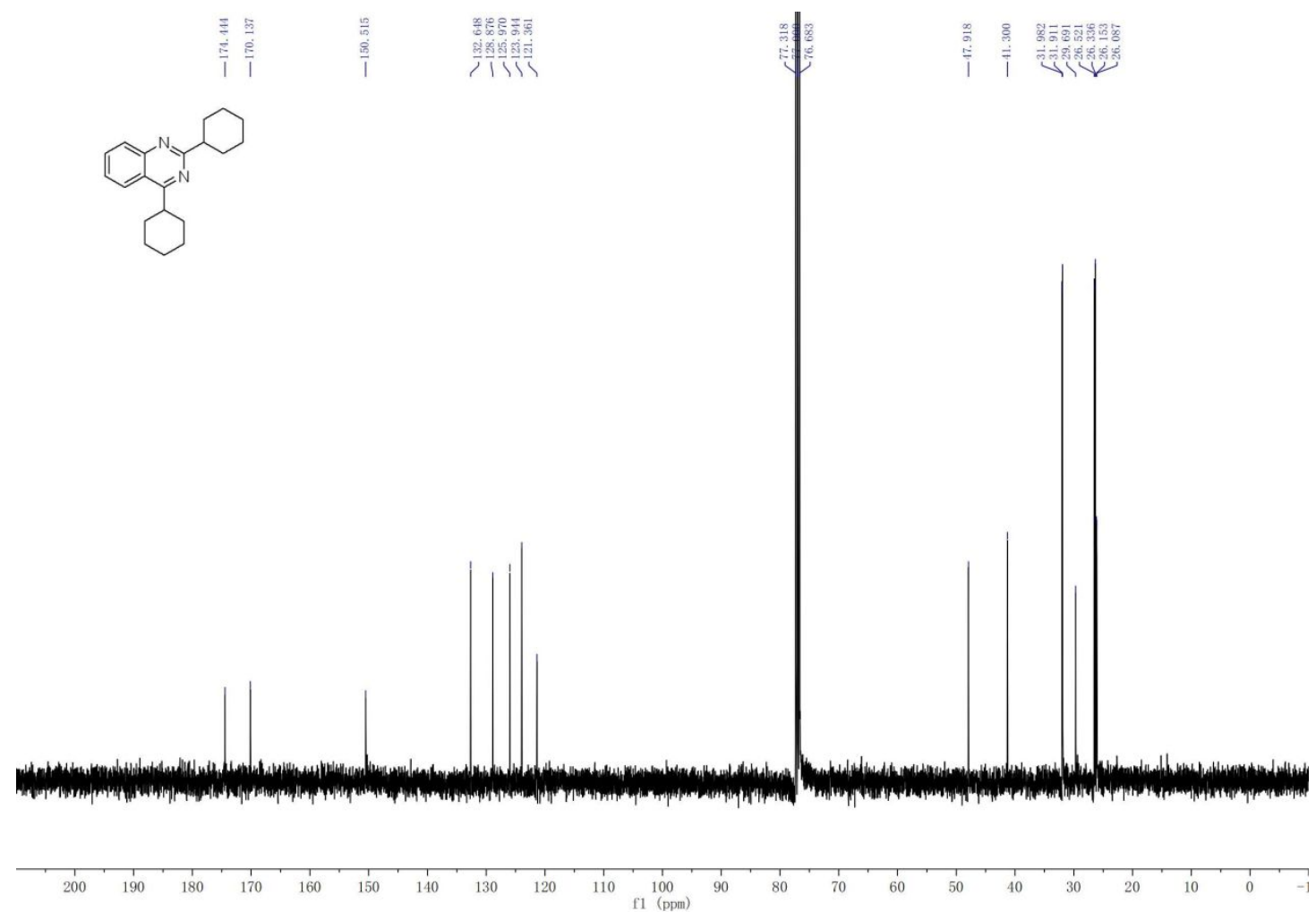

Figure S133. ${ }^{13} \mathrm{C}$ NMR Spectra of 6ad' 